\title{
PILOT PLANT STUDY OF AQUEOUS LINEAR ALKYLBENZENE SULFONATE DEGRADATION BY COMBINED ADVANCE OXIDATION AND BIOLOGICAL PROCESSES
}

by

Gelareh Bankian Tabrizi

(B.Sc., Sharif University of Technology, Iran, 1994)

\author{
A thesis \\ presented to Ryerson University \\ in partial fulfillment of the \\ requirements for the degree of \\ Master of Applied Science \\ in the Program of \\ Chemical Engineering
}

Toronto, Ontario, Canada, 2004

(c) Gelareh Bankian Tabrizi, 2004 


\section{UMI Number: EC52978}

\section{All rights reserved \\ INFORMATION TO USERS}

The quality of this reproduction is dependent upon the quality of the copy submitted. Broken or indistinct print, colored or poor quality illustrations and photographs, print bleed-through, substandard margins, and improper alignment can adversely affect reproduction.

In the unlikely event that the author did not send a complete manuscript and there are missing pages, these will be noted. Also, if unauthorized copyright material had to be removed, a note will indicate the deletion.

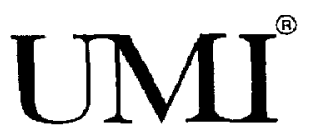

UMI Microform EC52978

Copyright 2008 by ProQuest LLC

All rights reserved. This microform edition is protected against unauthorized copying under Title 17, United States Code.

ProQuest LLC

789 East Eisenhower Parkway

P.O. Box 1346

Ann Arbor, MI 48106-1346 
I hereby declare that I am the sole author of this thesis.

I authorize Ryerson University to lend this thesis to other institutions or individuals for the purpose of scholarly research.

\section{Gelareh Bankian Tabrizi}

I further authorize Ryerson University to reproduce this thesis by photocopying or by other means, in total or in part, at the request of other institutions or individuals for the purpose of scholarly research.

Gelareh Bankian Tabrizi 
Ryerson University requires the signatures of all persons using or photocopying this thesis. Please sign below, and give address and date. 


\title{
ABSTRACT \\ Pilot plant study of Aqueous Linear Alkylbenzene Sulfonate degradation by combined Advance Oxidation and Biological Processes
}

\author{
Gelareh Bankian Tabrizi \\ MASc, Chemical Engineering Program \\ Ryerson University
}

Toronto, 2004

Photochemical degradation of linear alkylbeneze sulfonate (LAS) using a pilot plant photoreactor is studied. LAS at $100 \mathrm{mg} / \mathrm{L}$ is degraded by UV-254 and $\mathrm{UV} / \mathrm{H}_{2} \mathrm{O}_{2}$. Degradation of LAS is effectively enhanced by $720 \mathrm{mg} / \mathrm{L} \mathrm{H}_{2} \mathrm{O}_{2}$. Moreover, the effectiveness of photo-treatment on the biodegradability of LAS is examined. Both pretreated and untreated LAS are used in biological experiments. Combination of UV-254 with optimum concentration of $\mathrm{H}_{2} \mathrm{O}_{2}$ effectively enhanced the biodegradability of LAS. However, LAS at $100 \mathrm{mg} / \mathrm{L}$ can inhibit the growth of microorganisms. It is observed that the adaptation of activated sludge increases the biodegradation of LAS. However, due to the presence of intermediates in the effluent of the photoreactor, the biodegradability of this effluent is less than the biodegradability of the same as the concentration of untreated LAS. It is also observed that using the integration of $\mathrm{UV} / \mathrm{H}_{2} \mathrm{O}_{2}$ and biological processes instead of single step of $\mathrm{UV} / \mathrm{H}_{2} \mathrm{O}_{2}$, reduces the total residence time in chemical reactor while obtains the desired total efficiency. 


\section{ACKNOWLEDGMENT}

I would like to show my special thanks to my supervisor, Dr. Mehrab Mehrvar, for his guidance and support throughout the research to accomplish this thesis. I would also like to thank Natural Sciences and Engineering Research Council of Canada (NSERC) for funding this research. I would like to thank the faculty members and technologists in the Chemical Engineering Department of Ryerson University. I would also show my gratitude to my family for their patience and support to complete my study. Finally, I would like to thank my colleagues, my friends in Chemical Engineering Department for their help during my studies. 


\section{TABLE OF CONTENTS}

Chapter 1: Introduction.

Chapter 2: Literature Background. 3

2.1 Introduction (combined chemical and biological processes)......................3

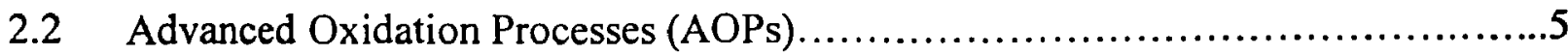

2.2.1 Processes for generating oxidant radicals...............................7

2.3 Biological Treatment of Wastewater...........................................

2.4 Combined chemical and biological processes..................................10

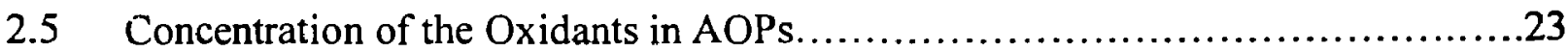

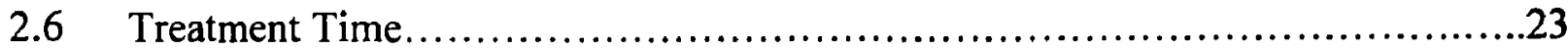

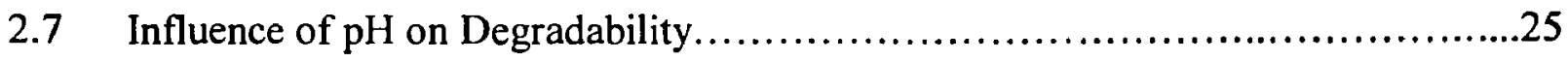

2.8 Influence of Temperature on the Degradability of Pollutants.....................27

2.9 Measurement Parameters in Biodegradability .................................28

2.10 Microorganism's Adaptation.....................................................

2.11 Removal of Residual Oxidant.............................................. 31

2.12 Optimum Situation for Biological Post-Treatment.............................31

2.13 Mathematical Models for Chemical and Biological Reactions.....................31

2.14 Background (Linear alkylbenzene sulfonate) ...................................32

2.15 Environmental concerns and biodegradability of LAS ..........................33

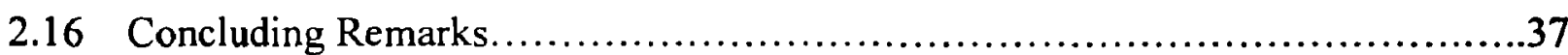

Chapter 3: Materials, Methods, and Equipment

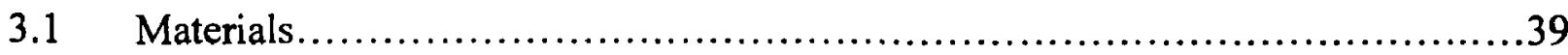

3.1.1 Linear Alkylbenzene Sulfonate (LAS) ...............................39

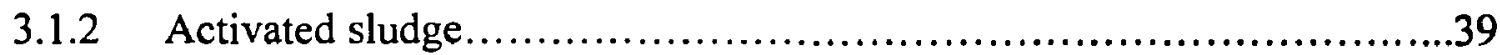

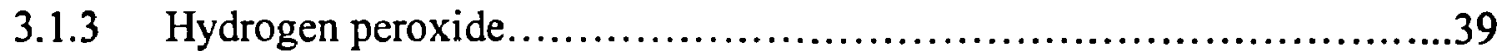

3.1.4 Catalase ...........................................................

3.1.5 Chemicals for analysis of LAS........................................44

3.1.6 Nutrients for biological measurements.................................44 
3.1.7 Standard check solution for biological measurements....................45

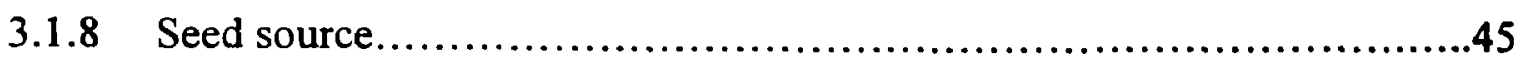

3.1.9 Reagents for hydrogen peroxide analysis........................... 45

3.1.10 Check kit for free chlorine..............................................45

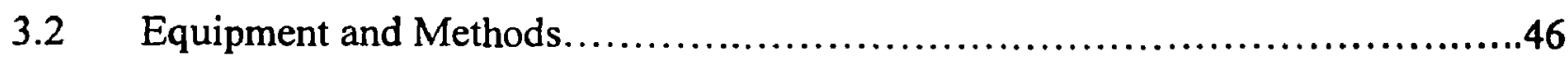

Photolytic Processes...................................................46

3.2.1 Experimental set-up (Photoreactor) .................................46

3.2.2 $\mathrm{pH}$ measurement..................................................48

3.2.3 UV spectrophotometer........................................48

3.2.4 Preparation of the initial solution for photolytic experiments ...............49

3.2.5 Measurement for linear alkylbenzene sulfonate.........................49

3.2.6 Chemical Oxygen Demand (COD) ....................................50

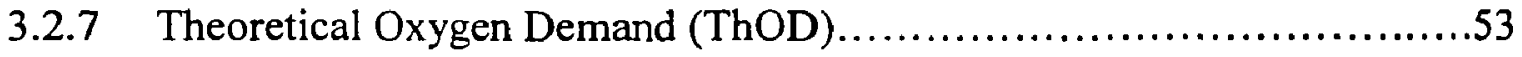

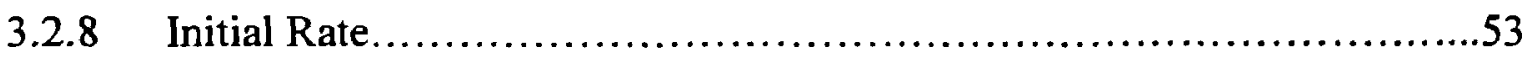

3.2.9 Free Chlorine Experiment.............................................

3.2.10 Dark Reaction Experiment.......................................55

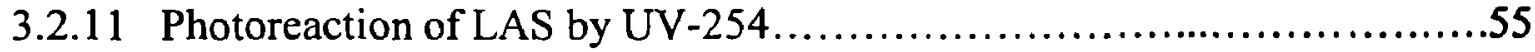

3.2.12 Mixing Speed Experiment............................................55

Biological Processes....................................................56

3.2.13 Experimental set-up (Sequential Batch Reactor) .....................56

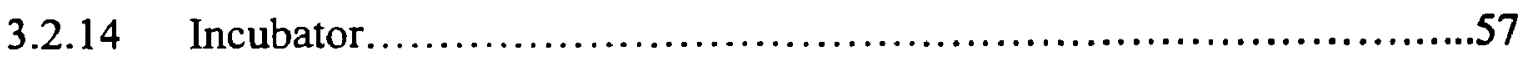

3.2.15 Dissolved Oxygen Meter........................................57

3.2.16 Biological Oxygen Demand (BOD) ..............................60

3.2.17 Ultimate Biological Oxygen Demand..............................62

3.2.18 Hydrogen Peroxide measurement..................................64

3.2.19 Mixed liquor suspended solids (MLSS) ..........................65

3.2.20 Shake Flask Tests for Biodegradation of LAS........................65

3.2.21 Biological Treatment of LAS using Sequential Batch Reactors.............65

Chapter 4: Results and Discussions...............................................68

4.1 Photolytic treatment...................................................68 
4.1.1 Free chlorine.....................................................68

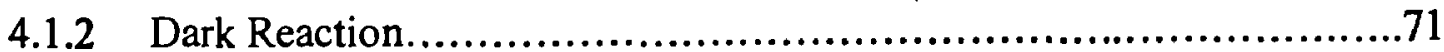

4.1.3 Photoreaction of LAS by UV-254 ................................73

4.1.3.1 Effect of flow rate.......................................73

4.1.3.2 Effect of mixing speed on the degradation....................75

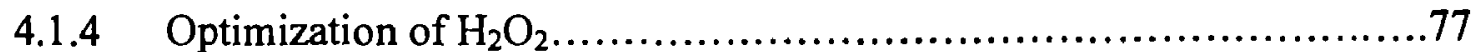

4.1.5 Model for the degradation of LAS with $\mathrm{UV}+\mathrm{H}_{2} \mathrm{O}_{2} \ldots \ldots \ldots \ldots \ldots \ldots \ldots . . . .11$

4.1.6 Comparison of $\mathrm{UV}+\mathrm{H}_{2} \mathrm{O}_{2}$ versus each alone........................82

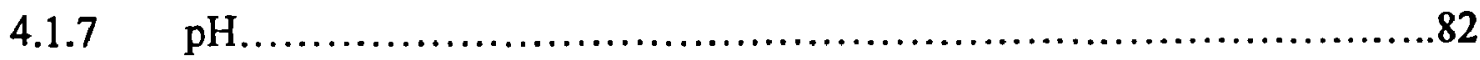

4.1.8 Impact of the Catalase on Analysis...................................86

4.1.9 Impact of $\mathrm{H}_{2} \mathrm{O}_{2}$ on $\mathrm{COD}$ and $\mathrm{BOD}$ tests..........................88

4.1.10 Consumption of $\mathrm{H}_{2} \mathrm{O}_{2}$ during the Reaction..........................90

4.2 Effects of Pre-Treatment on the Biodegradability of LAS ......................92

4.2.1 Biological oxygen demand for LAS...............................92

4.2.2 Ultimate BOD for the biodegradation of LAS ...........................99

4.2.3 Shake flask test for the biodegradation of LAS ......................100

4.2.4 Biological treatment of LAS using Sequential Batch Reactor.............110

4.3 Comparison between Combination of Photo-chemical and Biological

Processes for the Treatment of LAS versus Photo-chemical treatment alone.........119

4.3.1 Characteristics for the integration of AOP and biological processes.......124

4.3.2 Solution of the Optimization Procedures.................................128

Chapter 5: Conclusions and Recommendations......................................134

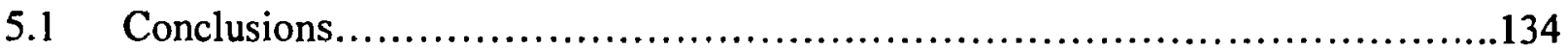

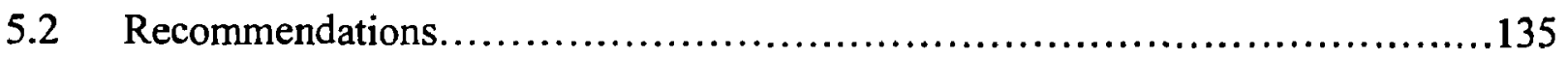

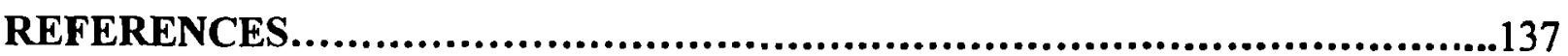

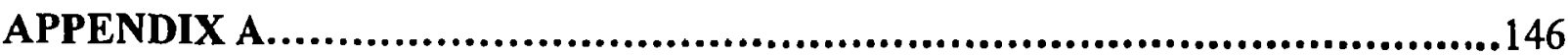

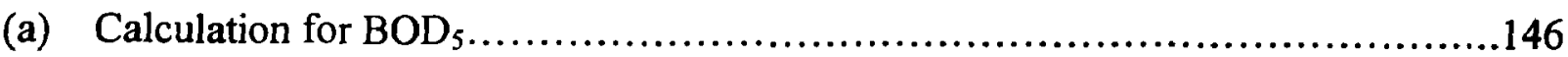

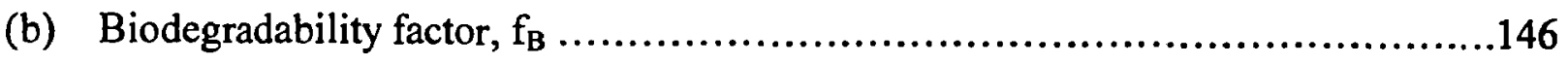




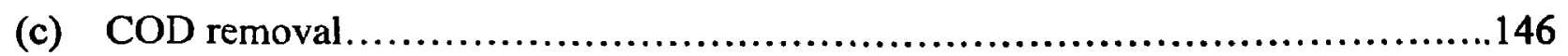

(d) Calculation for the non-biodegradable COD .................................147

(e) Theoretical Oxygen Demand (ThOD) ...................................... 147

(f) Calculation for MLSS ....................................................147

(g) Calculation for the nitrogen and phosphorus for biological treatment............... 148

(h) Calculation for Reynolds number...........................................148

(i) Calculation for the optimum concentration of catalase to remove $\mathrm{H}_{2} \mathrm{O}_{2} \ldots \ldots \ldots \ldots . .148$

(j) Kinetic model for the intermediate............................................ 149

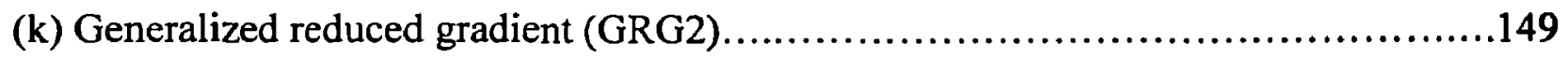

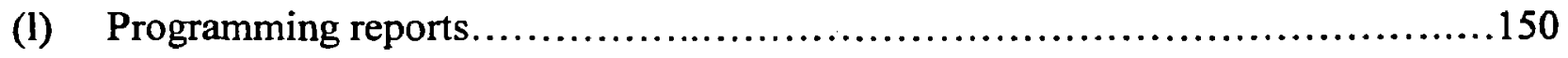




\section{LIST OF FIGURES}

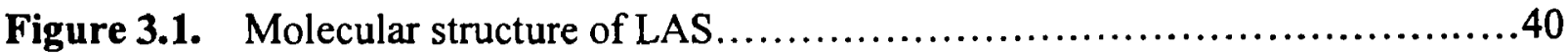

Figure 3.2. The scanning of LAS with UV-spectrophotometer................... 41

Figure 3.3. Molecular structure of Heme group attaching to the rest of the enzyme, representing the catalase enzyme....

Figure 3.4. Schematic diagram of the treatment system

Figure 3.5. The calibration curve for LAS using MBAS method.

Figure 3.6. Calibration curve for determination of COD, based on the closed refluxed method. .54

Figure 3.7. Schematic diagram of sequential batch reactor tank. .59

Figure 3.8. Calibration curve for determination of $\mathrm{H}_{2} \mathrm{O}_{2}$ .66

Figure 4.1. Difference between the photolytic degradation of LAS in the presence and absence of free chlorine

Figure 4.2. Comparing the initial rate for four different cases in photolytic degradation of LAS in the presence and absence of free chlorine ...............70

Figure 4.3. Changes in the concentration of LAS during dark reaction.................72

Figure 4.4. LAS concentration in the stabilization period...........................74

Figure 4.5. The initial rate for photolytic degradation of LAS...........................76

Figure 4.6. The rate constants for the second order reaction of photolytic degradation of LAS versus changing the mixing speed...............................78

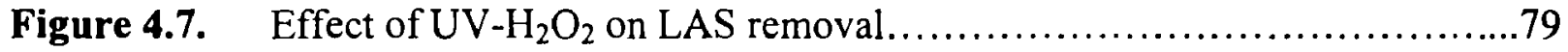

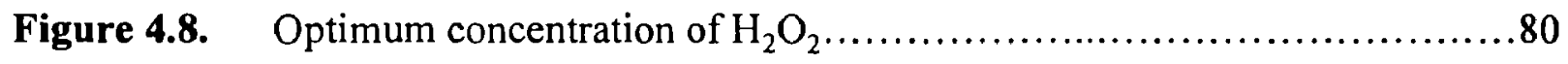

Figure 4.9. Comparison between the experimental data and simulated model for first order reaction of photolytic degradation of LAS .......................83

Figure 4.10. Comparison of the degradation rate for three different situations............84

Figure 4.11. The necessary time for the complete photolytic degradation of LAS using optimum concentration of $\mathrm{H}_{2} \mathrm{O}_{2} \ldots \ldots \ldots \ldots \ldots \ldots \ldots \ldots \ldots \ldots \ldots$

Figure 4.12. Comparison between the changes in $\mathrm{pH}$ with $\mathrm{UV}_{254}$

$\mathrm{UV}+\mathrm{H}_{2} \mathrm{O}_{2}$

Figure 4.13. The impact of the addition of insufficient or excessive 
amount of catalase on $\mathrm{BOD}_{5}$ test for different concentrations of catalase

Figure 4.14. Changes in COD during the photolytic degradation of LAS

with $\mathrm{H}_{2} \mathrm{O}_{2}$ without elimination of $\mathrm{H}_{2} \mathrm{O}_{2}$ and after elimination of $\mathrm{H}_{2} \mathrm{O}_{2} \ldots \ldots \ldots \ldots \ldots \ldots 1$

Figure 4.15. Consumption of $\mathrm{H}_{2} \mathrm{O}_{2}$ during the photolytic reaction using

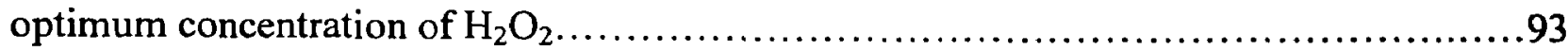

Figure 4.16. BOD5 for 4 different concentrations of untreated LAS.....................95

Figure 4.17. Ratio of BOD5/COD for 4 different concentrations

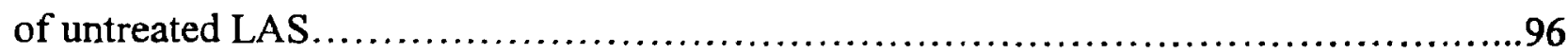

Figure 4.18. Comparison between the ratio of $\mathrm{BOD}_{5} / \mathrm{COD}$ and decreasing in the concentration of LAS during photolytic treatment with $\mathrm{H}_{2} \mathrm{O}_{2}$ as an oxidant.

Figure 4.19. Increasing in the biodegradability factor of LAS

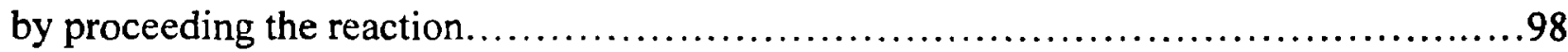

Figutre 4.20. BOD for three samples in a 30 days treatment period...................101

Figure 4.21. Changes in the DO during the shake flask experiment...................106

Figure 4.22. The changes in the degradation of untreated LAS

at $40 \mathrm{mg} / \mathrm{L}$ in the liquid phase and in the adsorbed phase in shake flask.................107

Figure 4.23. The changes in the degradation of pre-treated LAS

in the liquid and solid phase in shake flask ...................................... 108

Figure 4.24. The degradation of pre-treated LAS and untreated LAS

with no previous pre-treatment but at the same concentration in shake flask.............109

Figure 4.25. First order model for the biological degradation of two

kinds of LAS in shake flask.

Figure 4.26. First order model for the biological degradation of

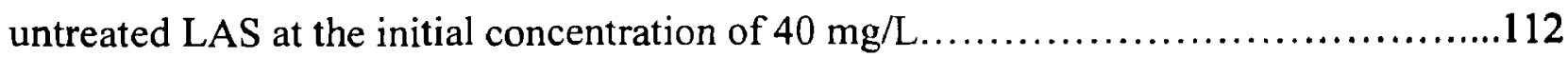

Figure 4.27. Gradual increase in the concentration of LAS in SBR ..................115

Figure 4.28. Changes in the $\mathrm{DO}$ and $\mathrm{BOD}_{5}$ during the acclimation period of LAS......116

Figure 4.29. $\mathrm{pH}$ during the acclimation period of LAS .........................117

Figure 4.30. Changes in the concentration of pre-treated LAS, and its COD,

and $\mathrm{BOD}_{5}$

Figure 4.31. The difference between the biodegradation of photo-treated LAS with the same concentration of LAS without any pre-treatment in SBR with 
adapted microorganisms.

Figure 4.32. First order model for the biological degradation

of LAS in SBR with adapted microorganisms......

Figure 4.33. Comparison between experimental data for biological treatment

pre-treated LAS in SBR with simulated data of first order reaction rate

Figure4.34. The kinetic model for $\mathrm{A}$ and $\mathrm{S}$ in the chemical reactor

Zero order kinetic rate for consumption of $\mathrm{H}_{2} \mathrm{O}_{2}$ versus time 


\section{LIST OF TABLES}

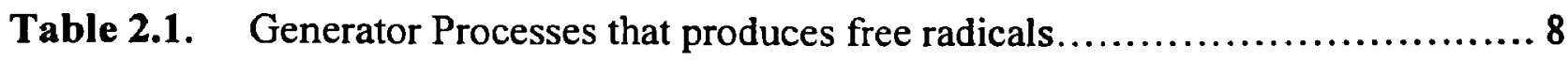

Table2.2. Summary of the recent studies on the combined

chemical and biological treatment of organic pollutants in water and

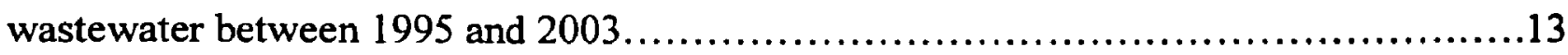

Table 2.3. Previous work done on chemical degradation of LAS ......................35

Table 3.1. The speed in rpm for each number on the mixer installed

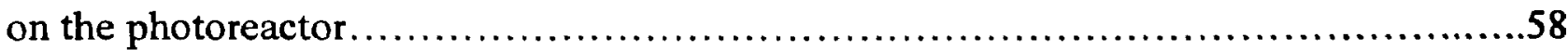

Table 3.2. The volume of wastewater added to the bottles for BOD measurement.........63

Table 4.1. BOD models for three different samples................................102

Table 4.2. Different rate constants for different types of LAS, and adapted

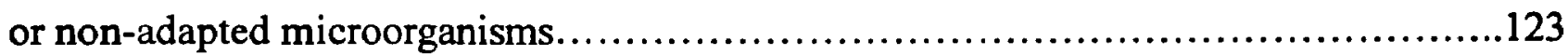

Table 4.3. Optimization results for the combined system.............................130 


\section{NOMENCLATURE}

AOP Advance Oxidation Process

LAS Linear Alkylbeneze Sulfonate

WHO World Health Organization

UV Ultra Violet

EPA Environmental Protection Agency

RBC Rotary Biological Contactor

COD Chemical Oxygen Demand

BOD Biological Oxygen Demand

DOC Dissolved Organic Carbon

TOC Total Organic Carbon

OUR Oxygen Uptake Rate

SOUR Specific Oxygen Uptake Rate

MLSS Mixed Liquor Suspended Solid

SS Suspended Solid

TKN Total Kjeldahl Nitrogen

AOS Average Oxidation State

MLVSS Mixed Liquor Volatile Suspended Solid

SVI Sludge Volume Index

HRT Hydraulic Retention Time

GPM Gallons Per Minute

LPM Liters Per Minute

MBAS Mathylene Blue Active Substances

ThOD Theoretical Oxygen Demand

KHP Potassium Hydrogen Phthalate

SBR Sequential Batch Reactor

DO Dissolved Oxygen

UBOD Ultimate Biological Oxygen Demand

DMP 2,9-dimethyl-1,10-phenanthroline

DPD N,N-diethyl-p-phenylenediamine 



\section{CHAPTER 1}

\section{INTRODUCTION}

Each year the ecosystem receives large quantities of surfactants, which are the main component of widely used laundry detergents, cleaners, and shampoos. Moreover, surfactants are widely used in industries. Among them, linear alkylbenzene sulfonate (LAS), the most common synthetic anionic surfactant used in domestic and industrial detergents, has a global production of $2.4 \times 10^{6}$ tonnes per year (De Almeida et. al., 1994). LAS was first introduced in 1965 as a biodegradable compound to substitute nonbiodegradable compounds in detergents (Huang et al., 2000). It is produced by sulfonation of linear alkylbenzene with sulfur trioxide. Detergents contain 5-25\% LAS and the length of its chain ranges from $C_{10}$ to $C_{14}$ (WHO, 1996). As it was reported that higher concentration of LAS does not respond to biological treatments (Zhang et al., 1998), many investigators have tried degrading LAS using chemical processes. Among the several chemical treatments, advanced oxidation processes (AOPs) such as UV and $\mathrm{UV} / \mathrm{H}_{2} \mathrm{O}_{2}$ have been used as an attractive alternative for the treatment of wastewaters containing bioresistant compounds successfully. AOPs are technologies for the production of highly reactive intermediates, mainly hydroxyl radicals $(\mathrm{OH})$, which are able to oxidize almost all organic pollutants. During photolysis, UV light with the wavelength energy of more than bond energy can break the bond directly. While in the case that UV is combined with hydrogen peroxide, $\mathrm{H}_{2} \mathrm{O}_{2}$ absorbs light at $254 \mathrm{~nm}$ to produce hydroxyl radicals. These hydroxyl radicals react with the organic pollutants producing aldehydes, alcohols, and carboxylic acids. In the case of complete mineralization, the products would be $\mathrm{CO}_{2}$ and $\mathrm{H}_{2} \mathrm{O}$. AOPs have shown their worthiness for toxic compounds elimination in water and wastewater treatment, however, the total mineralization through these processes is very expensive. On the other hand, biological treatment is relatively cheap and reliable process, but there are many non-biodegradable and bioresistant compounds. Therefore, a combination of both processes would mean a cheaper option for total organic degradation from a toxic wastewater or a wastewater containing refractory organics. It has been observed by many investigators that the 
coupling of a bioreactor and advanced oxidation processes (AOPs) could reduce the final concentrations of the effluent to the desired values. However, optimizing the total cost of the treatment is a challenge, as AOPs are much more expensive than biological processes alone. Therefore, an appropriate design should not only consider the ability of this coupling to reduce the concentration of organic pollutants, but also try to obtain the desired results in a cost effective process.

The objectives of this research were to investigate the possibility of degrading an anionic surfactant, linear alkylbenzene sulfonate, by combining photolytic with biological treatment. The following experiments were conducted to study that possibility.

- Photolytic treatment of LAS with UV-254 and combination of UV and $\mathrm{H}_{2} \mathrm{O}_{2}$ to find the rate of degradation of each process

- Effects of photolytic pretreatment of LAS by UV/ $/ \mathrm{H}_{2} \mathrm{O}_{2}$ on its biodegradability

- Combination of photolytic pretreatment of LAS by $\mathrm{UV} / \mathrm{H}_{2} \mathrm{O}_{2}$ and subsequent aerobic biological treatment using unadapted and adapted activated sludge for an effective treatment of LAS 


\section{CHAPTER 2}

\section{LITERATURE BACKGROUND}

This chapter is divided into two parts. The first part deals with different advanced oxidation processes for the treatment of aqueous organics. Moreover, a comprehensive review on the combination of chemical and biological treatment is presented based on the previous work (Bankian and Mehrvar, 2004). The effects of different parameters during this combination, depending on the type of treatment, are described. A brief discussion of the compounds used in this research is described in the second part of this chapter.

\subsection{Introduction}

Increased knowledge about the consequences from water pollution, public desire for better quality of water, having a better environment, diminishing water resources, the rapid growth, and the industrial development have created the need to have regulations such as United States Environmental Protection Agency (USEPA). Also the reuse of the municipal and industrial wastewater and the recovery of potential pollutants used in industrial processes become more critical. Hence, the role of the wastewater treatment is becoming more and more important as both the effluent quality and quantity are subjected to more strict regulations. Technological advancement to minimize the use of wastewater may help reduce the effluent quantity, whereas cost-effective wastewater treatment can be adopted to reduce pollutant concentrations to acceptable levels.

Wastewaters from chemical, pharmaceutical, and dye industries most often contain significant amount of non-biodegradable organic compounds. The elimination of these non-biodegradable toxic contaminants is required before biological treatment. Although the biological treatment of wastewater is often the most economical alternative

process when compared to other treatment options such as AOPs, the ability of a compound to undergo biological degradation depends on a variety of factors. Such 
factors include the concentrations, chemical structures, and the biodegradability of the target molecules. Characteristics of the wastewater, such as $\mathrm{pH}$, alkalinity, or the presence of an inhibitory compound could also play an important role in the biological degradation of pollutants. Although many organic molecules are readily biodegradable, many other synthetic and naturally existing organic molecules are biorecalcitrant, i.e., resistant to biodegradation. Depending on the nature of the pollutants and the level of contaminants, detoxification might be difficult and/or expensive to achieve by conventional biological methods. In such cases, biological processes alone are not able to reach effluent standards for the discharge into municipal sewer or into surface water; therefore, a pre-treatm sost-treatment is required. The choice of the correct combination system must de carried out considering several factors, both technical (treatment efficiency, plant simplicity, flexibility, etc.) and economical (capital and operating costs including reagent and energy consumption, sludge and gas disposal, maintenance, etc.) aspects. In several cases, specific experimental tests are required in order to assess actual efficiency and proper treatment conditions. Moreover, advanced oxidation processes (AOPs) such as $\mathrm{UV}, \mathrm{UV} / \mathrm{H}_{2} \mathrm{O}_{2}, \mathrm{UV} / \mathrm{O}_{3}, \mathrm{UV} / \mathrm{H}_{2} \mathrm{O}_{2} / \mathrm{O}_{3}$, and $\mathrm{UV} / \mathrm{TiO} \mathrm{O}_{2}$ have been used as an attractive alternative for the treatment of these types of wastewaters. AOPs are technologies for the production of highly reactive intermediates, mainly hydroxyl radicals $(\mathrm{OH})$, which are able to oxidize almost all organic pollutants. Advanced oxidation processes can reduce pollutant concentrations, and some processes produce more oxidized compounds, which are in most cases more easily biodegradable than the former ones. Although AOPs are expensive to install and operate, they may be unavoidable for the tertiary treatment of refractory organics present in industrial effluents to allow safe discharge of industrial contaminants. Despite the effectiveness of AOPs, there are several scenarios that make them economically disadvantageous. Effective treatment of a particular industrial wastewater may require a combination of AOPs and biological processes in order to exploit their individual quantities and, thus, reach the desired quality within reasonable economical limits.

On one hand, AOPs have shown their worthiness for toxic compounds elimination in water and wastewater treatment, however, the total mineralization through these 
processes is very expensive. On the other hand, biological treatment is relatively cheap and reliable process but there are substances, which are unable to deal with. A combination of both processes would mean a cheaper option for total organic degradation from a toxic wastewater or a wastewater containing refractory organics.

It has been shown that the combination of biological and advanced oxidation processes has the following advantages (Lee et al., 2001):

1. Synergistic effect as chemical and biological processes are accompanimentf of each other.

2. Protection of the biological culture from inhibitory or toxic compounds by chemical pre-treatment.

3. Reduction in chemical dosage cost by the use of cost-effective biological pre or post-treatment.

4. Flexibility in total residence time as a result of different choices that is possible for chemical and biological reactor residence times in a constant efficiency.

5. Achieving complete pollutant mineralization while minimizing the total cost.

\subsection{Advanced Oxidation Processes (AOPs)}

AOPs are fairly new technologies which have been developed since 1975 (Zhou and Smith, 2001) and are of considerable interest in water and wastewater treatment. They are promising technologies for the removal of contaminated ground and surface water as well as wastewaters containing non-biodegradable or inhibitory organics to microbial growth. The main advantage of AOPs is their ability to destroy the organic compounds in water without transferring them to another medium or generating secondary waste disposal problems. A broad range of compounds may be treated by AOPs. AOPs work by destroying the organic compounds in water and wastewater by oxidation. The most commonly used AOPs use $\mathrm{H}_{2} \mathrm{O}_{2}, \mathrm{O}_{3}$, or $\mathrm{O}_{2}$ as an oxidant. These involve producing free radicals such as ${ }^{\circ} \mathrm{OH}$, from the molecular oxidant by means of energy or catalyst. For example, hydrogen peroxide may generate hydroxyl radicals in the presence of UV light with the wavelength of less than $254 \mathrm{~nm}$ based on the following reaction: 
$\mathrm{H}_{2} \mathrm{O}_{2}+h v \rightarrow 2^{\circ} \mathrm{OH}$

These hydroxyl radicals are able to attack pollutants by addition to double bond, abstraction a hydrogen atom, or transferring an electron to a halogenated compound according to the following reactions (Braun and Oliveros, 1997):

-Addition

$\cdot \mathrm{OH}+\mathrm{X}_{2} \mathrm{C}=\mathrm{CX}_{2} \rightarrow \mathrm{X}_{2} \mathrm{C}(\mathrm{OH})-\mathrm{C}^{\cdot} \mathrm{X}_{2}$

-Hydrogen abstraction

$\cdot \mathrm{OH}+\mathrm{RH} \rightarrow \mathrm{H}_{2} \mathrm{O}+\mathrm{R}^{\bullet}$

- Electron transfer

$\cdot \mathrm{OH}+\mathrm{RX} \rightarrow \mathrm{OH}^{-}+\mathrm{XR}^{+\bullet}$

where $\mathrm{R}$ represents a typical hydrocarbon and $\mathrm{X}$ represent a halogenated group.

The products of the organic molecule could be intermediates, or at the final stage either $\mathrm{HCO}_{3}{ }^{-}, \mathrm{Cl}^{-}, \mathrm{NO}_{3}^{-}, \mathrm{CO}_{2}$, or $\mathrm{H}_{2} \mathrm{O}$.

The oxidation of organics is defined by the extent of their degradation to the final oxidation products as follows:

1. Primary degradation which is a structural change in parent compounds.

2. Satisfactory degradation, a primary degradation that reduces the toxicity or converts non-biodegradable organics to biodegradable ones.

3. Complete mineralization or ultimate degradation, changing the organics into $\mathrm{CO}_{2}$ and water.

4. Improper degradation, a change in the structure of the parent compounds in a way that increases the toxicity of the wastewater.

An important disadvantage of AOPs is their high capital and operating costs in comparison to the conventional biological treatment. However, by considering their advantages, AOPs could be used as a pre- or post-treatment step to enhance the biodegradability of the wastewater containing recalcitrant or inhibitory organics, and even rendering the wastewater ambient for reuse. 


\subsubsection{Processes for generating oxidant radicals}

The versatility of AOPs is also enhanced by the fact that they offer different ways of producing hydroxyl radicals, which allow gaining specific treatment requirements. The following is a list of different AOPs, which are able to produce the highly reactive hydroxyl radicals:

- UV

- $\mathrm{H}_{2} \mathrm{O}_{2} / \mathrm{UV}$

- $\mathrm{O}_{3} / \mathrm{UV}$

- $\mathrm{O}_{3} / \mathrm{UV} / \mathrm{H}_{2} \mathrm{O}_{2}$

- $\mathrm{O}_{3}$

- $\mathrm{O}_{3} / \mathrm{H}_{2} \mathrm{O}_{2}$

- $\mathrm{H}_{2} \mathrm{O}_{2} / \mathrm{Fe}^{2+}$ (Fenton)

- $\mathrm{H}_{2} \mathrm{O}_{2} / \mathrm{Fe}^{2+} / \mathrm{UV}$ (Photo-Fenton)

- $\mathrm{TiO}_{2} / \mathrm{UV}$ (Photocatalysis)

- $\mathrm{TiO}_{2} / \mathrm{UV} / \mathrm{H}_{2} \mathrm{O}_{2}$

Types of radicals generated by different methods of AOPs are as listed Table 2.1 (Gulyas, 1997).

\subsection{Biological Treatment of Wastewater}

Biological oxidation has been the main technology capable of reducing the contaminant level of wastewater for many years. The overall objectives of the biological wastewater treatment are to transform biodegradable compounds into acceptable end products, transform or remove nutrients, capture suspended solids, and incorporate nonsettleable colloidal solids into biological flocs. The objective of the industrial wastewater treatment is to remove and reduce the concentration of organic and inorganic compounds. Although some of the organics are toxic or inhibitory to microbial growth, a preliminary chemical oxidation step may eliminate refractory or toxic substances. The main benefit of 
Table 2.1: Generator Processes that produces free radicals

\begin{tabular}{|c|c|}
\hline Free Radicals & Generator Processes \\
\hline \multirow[t]{9}{*}{${ }^{\circ} \mathrm{OH}$} & $\mathrm{H}_{2} \mathrm{O}_{2} / \mathrm{Fe}^{2+}$ \\
\hline & $\mathrm{H}_{2} \mathrm{O}_{2} / \mathrm{Fe}^{2+} / \mathrm{UV}$ \\
\hline & $\mathrm{H}_{2} \mathrm{O}_{2} / \mathrm{UV}$ \\
\hline & $\mathrm{O}_{3}$ \\
\hline & $\mathrm{O}_{3} / \mathrm{H}_{2} \mathrm{O}_{2}$ \\
\hline & $\mathrm{O}_{3} / \mathrm{UV}$ \\
\hline & $\mathrm{O}_{3} \mathrm{UV} / \mathrm{H}_{2} \mathrm{O}_{2}$ \\
\hline & $\mathrm{TiO}_{2} / \mathrm{UV}$ \\
\hline & $\mathrm{TiO}_{2} / \mathrm{UV} / \mathrm{H}_{2} \mathrm{O}_{2}$ \\
\hline \multirow[t]{4}{*}{$\mathrm{HO}_{2}^{\circ}$} & $\mathrm{H}_{2} \mathrm{O}_{2} / \mathrm{UV}$ \\
\hline & $\mathrm{O}_{3}$ \\
\hline & $\mathrm{O}_{3} / \mathrm{H}_{2} \mathrm{O}_{2}$ \\
\hline & $\mathrm{O}_{3} / \mathrm{UV} / \mathrm{H}_{2} \mathrm{O}_{2}$ \\
\hline \multirow[t]{3}{*}{$\mathrm{HO}_{3}^{\circ}$} & $\mathrm{O}_{3}$ \\
\hline & $\mathrm{O}_{3} / \mathrm{H}_{2} \mathrm{O}_{2}$ \\
\hline & $\mathrm{O}_{3} / \mathrm{UV} / \mathrm{H}_{2} \mathrm{O}_{2}$ \\
\hline \multirow[t]{3}{*}{$\mathrm{O}_{2}^{-}$} & $\mathrm{O}_{3}$ \\
\hline & $\mathrm{O}_{3} / \mathrm{H}_{2} \mathrm{O}_{2}$ \\
\hline & $\mathrm{O}_{3} / \mathrm{UV} / \mathrm{H}_{2} \mathrm{O}_{2}$ \\
\hline \multirow[t]{3}{*}{$\mathrm{HO}_{3}^{\circ}$} & $\mathrm{O}_{3}$ \\
\hline & $\mathrm{O}_{3} / \mathrm{H}_{2} \mathrm{O}_{2}$ \\
\hline & $\mathrm{O}_{3} / \mathrm{UV} / \mathrm{H}_{2} \mathrm{O}_{2}$ \\
\hline
\end{tabular}


the biological wastewater treatment is its relatively low operating cost and handling huge masses of compounds.

The principal biological processes used for wastewater treatment can be divided into the following main categories (Metcalf and Eddy, 2003, Eckenfelder, 2000):

- Suspended growth processes, in which microorganisms responsible for the conversion of the organic matter in the wastewater are suspended within the liquid (for example: activated sludge and aerated lagoons). The degree of organics removal for the activated sludge process is approximately $90 \%$ and for the aerated lagoons it is high in summer but not good in winter.

- Attached growth (biofilm) processes, in which microorganisms responsible for the conversion of the organic matter in the wastewater, are attached to some inert medium, such as rocks, slag, ceramic, or plastic materials (for example: trickling filters, rotary biological contactors (RBCs), and packed-bed reactors). The degree of the removal for these processes is intermediate to high depending on the loading of wastewater.

- Anaerobic processes: such as sludge blanket and upflow anaerobic sludge blanket. Their degree of removal is intermediate.

The successful design and operation require an understanding of the type of microorganisms and organic compounds, the environmental factors that affect the performance, and the types of reactors involved. The successful operation and removal of dissolved compounds in wastewater are done by a variety of microorganisms, principally bacteria. Microorganisms oxidize the dissolved and particulate carbonaceous organics into simple products and extra biomass. Among the environmental factors affecting the treatment process, temperature and $\mathrm{pH}$ have important effects on the selection, survival, and the growth of microorganisms. The optimal growth of a specific microorganism occurs in a fairy narrow range of temperature that differs from one group of bacteria to the other. Most bacteria cannot tolerate $\mathrm{pH}$ levels above 9.5 or below 4.0. Generally, the optimum $\mathrm{pH}$ for the growth and survival of the bacteria lies between 6.5 and 7.5. 


\subsection{Combined chemical and biological processes for the treatment of organic pollutants in water and wastewater}

Previously, a wild range of studies on the integration of biological and advanced oxidation processes prior to 1995 have been reviewed (Scott and Ollis, 1995). In this study, recent developments (1996-2003) on the integration of chemical and biological processes for the degradation and treatment of problematic pollutants in wastewater are classified in Table 2.2 (Bankian and Mehrvar, 2004). The studies were conducted on the integration of chemical and biological processes with different objectives, such as modeling the degradation in chemical and biological reactors, observing the effects of combination on total removal and comparing with individual processes, comparing the effects of different AOPs on the biodegradation of a certain compound, and investigating the effects of different parameters on the combination of processes. The compounds used were mostly difficult to degrade by biological processes alone and needed post- or pretreatment by AOPs. In most cases there was just one chemical reactor followed by biological reactor or vice versa in series. However, there is one case in which the chemical and biological reactors are parallel (Lee et al., 2001), three cases in which there are more than two stages for the treatment (Helble et al., 1999; Karer et al., 1997; and Fahmi et al, 2003), and four cases in which there is a biological pre-treatment followed by a chemical oxidation treatment step, which is followed by further biological treatment (Bertanza et al. 2001; Ito et al., 1998; Jochimsen and Jekel, 1997; and Mobius and Tolle, 1997). In such processes, the first biological step removes the biodegradable organics and the chemical reactor increases the biodegradability of residual organics for the second biological step.

As Table 2.2 illustrates, the treatment of some chemicals cannot be usually completed by either biological treatment or AOPs alone. In spite of the fact that AOPs are capable to produce high quality effluent in most cases, the important drawback of these processes is their high capital and operating costs such as chemicals, electricity, and sludge disposal. However, in order to avoid the high operation costs for complete oxidation, only partial oxidation is desired. It has been shown that a photochemical pretreatment step may enhance the biodegradability of wastewater containing recalcitrant or 
inhibitory compounds, if and only if, the intermediates produced are biodegradable and are more soluble and less toxic than the parent compounds. It has been frequently shown that the pre-oxidation by AOPs improves the biodegradability of non or poorly biodegradable organic compounds and this effect could be due to the change in their molecular structure. However, little is known about the exact mechanisms during the oxidation. The possible changes after oxidation and their effects on biodegradability could be due to the decrease of aromacity and destruction of high molecular structure, which leads to the formation of functional groups such as hydroxyl, carboxyl, and aldehyde (Jochimsen and Jekel, 1997). The effect on biodegradability of these chemical changes is significant on the enzyme activity. It can also be concluded that the destruction of toxic substances has positive effect on enzyme activity, whereas the formation of toxic metabolites had a negative effect on the inhibition of biochemical processes. Moreover, destruction of organic nitrification inhibitors causes an improvement in nitrification processes (Jochimsen and Jekel, 1997).

As a general treatment strategy, four types of treatment for a chemical compound are possible (Bertanza et al., 2001):

1. In some cases only biological treatment alone is sufficient to enhance the effluent quality.

2. In the presence of some refractory or toxic compounds in wastewater, chemical pretreatment is required.

3. In case biological treatment is not sufficient for biodegradable compounds, chemical post-treatment is also necessary.

4. In some rare cases, combination of chemical and biological treatment in multistages is necessary.

A general strategy that can be used to develop a combined advanced oxidation and biological processes for the treatment of a certain wastewater, which might contain non-biodegradable or toxic organics, is as follows:

As a first step to avoid utilization of high cost due to AOPs, it must be confirmed that whether the wastewater contains recalcitrant or toxic organics. If the wastewater is biodegradable, conventional biological reactors are used to treat the waste. If it is 
confirmed that wastewater contains recalcitrant or toxic organics, it would be pretreated by AOPs to modify the structure of pollutants by transforming them into less toxic and easily biodegradable intermediates, which are degraded in the subsequent biological reactor in a shorter time. This method can also prove to be less expensive in comparison to the AOPs alone and less time consuming compared to the biological process. Moreover, if the effluent from the final biological reactor has met the requirements, it will leave the treatment plant; otherwise it has to go through the previous cycle.

There are four types of wastewater, which have potential for increasing treatment efficiencies by combined processes as follows (Scott and Ollis, 1995).

1. Recalcitrant compounds

2. Biodegradable wastes with small amounts of recalcitrant compounds

3. Inhibitory compound

4. Intermediate dead-end products. 
Table 2.2. Summary of the recent studies on the combined chemical and biological treatment of organic pollutants in water and wastewater between 1995 and 2003

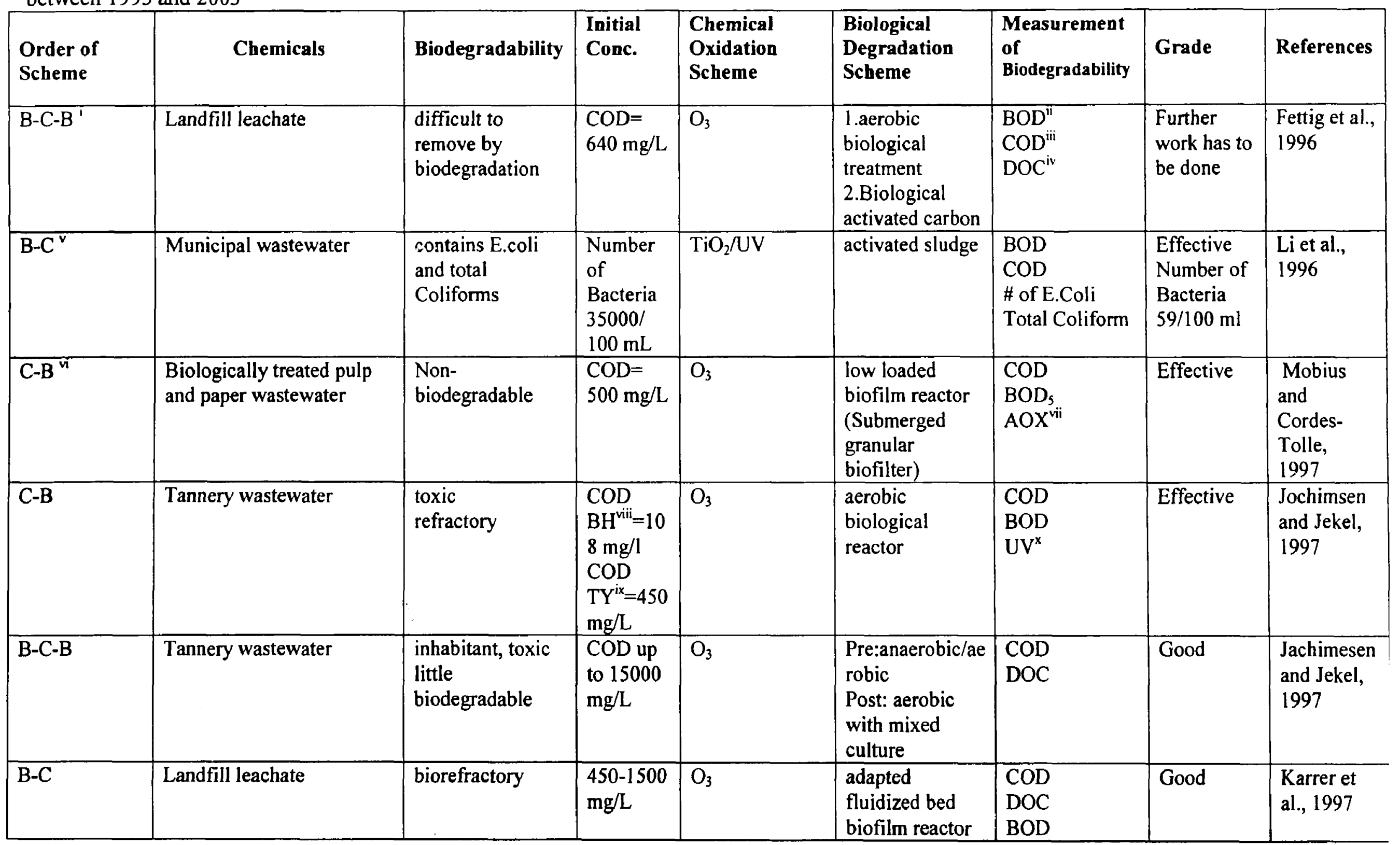




\begin{tabular}{|c|c|c|c|c|c|c|c|c|}
\hline $\begin{array}{l}\text { Biol/Oxil } \\
\text { Bio2/Oxi2 } \\
\text { Bio3/Oxi3 }\end{array}$ & $\begin{array}{l}\text { Synthetic wastewater } \\
\text { m-chloronitrobenzene } \\
\mathrm{Na} 2 \mathrm{HPO} 4 / \mathrm{NaH} 2 \mathrm{PO} 4 \\
\mathrm{Fe} \\
\mathrm{Co} \\
\mathrm{Mn} \\
\mathrm{Cu} \\
\mathrm{Zn} \\
\mathrm{NI} \\
\mathrm{Al} \\
\text { Distilled water }\end{array}$ & refractory & $\begin{array}{l}2 \mathrm{mM} \\
288 \mathrm{uM} \\
1.44 \mathrm{uM} \\
1.32 \mathrm{uM} \\
0.36 \mathrm{um} \\
0.02 \\
0.055 \\
0.047 \\
0.034\end{array}$ & $\mathrm{O}_{3}$ & $\begin{array}{l}\text { biological } \\
\text { reactor(BODs) }\end{array}$ & $\begin{array}{l}\text { DOC } \\
\text { COD } \\
\text { BOD }\end{array}$ & Efficient & $\begin{array}{l}\text { Karrer et } \\
\text { al., } 1997\end{array}$ \\
\hline $\mathrm{C}-\mathrm{B}$ & 2,4-dichlorophenol & $\begin{array}{l}\text { non- } \\
\text { biodegradable }\end{array}$ & $\begin{array}{l}\mathrm{COD}= \\
300 \mathrm{mg} / \mathrm{L}\end{array}$ & $\mathrm{O}_{3}$ & $\begin{array}{l}\text { activated } \\
\text { sludge(non- } \\
\text { adapted) } \\
\end{array}$ & $\begin{array}{l}\text { BOD } \\
\text { COD } \\
\text { TOC }\end{array}$ & Effective & $\begin{array}{l}\text { Marco et } \\
\text { al., } 1997\end{array}$ \\
\hline C-B & $\begin{array}{l}\text { Subsistent phenols } \\
\text { Amino- } \\
\text { Nitro- } \\
\text { Chloro- }\end{array}$ & $\begin{array}{l}\text { - degradable } \\
\text {-biorecalcitrant } \\
\text {-biorecalcitrant }\end{array}$ & $\begin{array}{l}\mathrm{COD}= \\
200 \mathrm{mg} / \mathrm{L}\end{array}$ & $\overline{\mathrm{O}_{3}}$ & activated sludge & $\mathrm{COD}$ & $\begin{array}{l}\text { Decrease in } \\
\text { Biodegrad- } \\
\text { ability } \\
\text { Very good } \\
\text { Very good }\end{array}$ & $\begin{array}{l}\text { Adams et } \\
\text { al., } 1997\end{array}$ \\
\hline C-B & $\begin{array}{l}\text { m-dinitrobenzene } \\
\text { diphenylamine resorcinol }\end{array}$ & $\begin{array}{l}\text { Inbibitory } \\
\text { realcitrant }\end{array}$ & $30 \mathrm{mg} / \mathrm{L}$ & $\mathrm{TiO}_{2} / \mathrm{UV}$ & BOD5 & $\begin{array}{l}\mathrm{BOD}_{1} / \mathrm{TOC} \\
\mathrm{COD}\end{array}$ & Good & $\begin{array}{l}\text { Bolduc and } \\
\text { Anderson, } \\
1997 \\
\end{array}$ \\
\hline C-B & Olive mil effluent & inhibitory & $\begin{array}{l}\mathrm{COD}= \\
121.8 \mathrm{~g} / \mathrm{L}\end{array}$ & $\mathrm{O}_{3}$ & $\begin{array}{l}\text { anaerobic } \\
\text { biological } \\
\text { reactor }\end{array}$ & $\mathrm{COD}$ & Bad effect & $\begin{array}{l}\text { Andreozzi } \\
\text { et al., } 1997\end{array}$ \\
\hline C-B & Urban wastewater & $\begin{array}{l}\text { some refractory } \\
\text { compounds }\end{array}$ & $\begin{array}{l}\mathrm{COD}= \\
286 \mathrm{mg} / \mathrm{L}\end{array}$ & $\begin{array}{l}\mathrm{O}_{3} \\
\mathrm{VU} / \mathrm{O}_{3} \\
\mathrm{O}_{3} / \mathrm{H}_{2} \mathrm{O}_{2} \\
\mathrm{UV} / \mathrm{H}_{2} \mathrm{O}_{2}\end{array}$ & activated sludge & $\begin{array}{l}\mathrm{COD} \\
\mathrm{BOD}_{5} \\
\mathrm{BOD}_{\mathrm{T}}^{\mathbf{x i}}\end{array}$ & $\begin{array}{l}\mathrm{O}_{3} \text { was The } \\
\text { best }\end{array}$ & $\begin{array}{l}\text { Beltran et } \\
\text { al., } 1997\end{array}$ \\
\hline B-C-B & trihalomethane (THM) & $\begin{array}{l}\text { Difficult to } \\
\text { remove by } \\
\text { biodegradation }\end{array}$ & $\begin{array}{l}\text { THMFP } \\
x^{\mathrm{iii}}=110- \\
20 \mathrm{ug} / \mathrm{L}\end{array}$ & $\begin{array}{l}\mathrm{O}_{3} / \mathrm{H}_{2} \mathrm{O}_{2} / \mathrm{UV} \\
\mathrm{O}_{3} / \mathrm{H}_{2} \mathrm{O}_{2} \\
\mathrm{O}_{3} / \mathrm{UV} \\
\mathrm{H}_{2} \mathrm{O}_{2} / \mathrm{UV} \\
\mathrm{O}_{3} \\
\mathrm{UV}\end{array}$ & activated sludge & $\begin{array}{l}\text { DOC } \\
\text { UV } 260\end{array}$ & $\begin{array}{l}\text { Efficiency } \\
\text { decreased } \\
\text { from top to } \\
\text { bottom }\end{array}$ & $\begin{array}{l}\text { Ito et al., } \\
1998\end{array}$ \\
\hline
\end{tabular}




\begin{tabular}{|c|c|c|c|c|c|c|c|c|}
\hline C-B & Wastewater sludge & $\begin{array}{l}\text { excess sludge } \\
\text { production }\end{array}$ & $\begin{array}{l}\text { TOC } \\
200 \mathrm{mg} / \mathrm{L}\end{array}$ & $\overline{\mathrm{O}_{3}}$ & activated sludge & $\begin{array}{l}\text { TOC } \\
\text { DOC } \\
\text { MLSS }^{\text {xiv }} \\
\text { SVI }^{\mathbf{w}}\end{array}$ & Effective & $\begin{array}{l}\text { Kamiya } \\
\text { and } \\
\text { Hirotusuji, } \\
1998\end{array}$ \\
\hline B-C & $\begin{array}{l}\text { Photo-processing waste } \\
\text { (PW) }\end{array}$ & $\begin{array}{l}\text { refractory } \\
\text { toxic }\end{array}$ & $\begin{array}{l}\mathrm{COD}_{\mathrm{Mn}}= \\
38000 \\
\mathrm{mg} / \mathrm{L} \\
\mathrm{COD}_{\mathrm{Cr}} \\
=70700 \\
\mathrm{mg} / \mathrm{L}\end{array}$ & $\begin{array}{l}\text { Fenton } \\
\text { oxidation }\end{array}$ & $\begin{array}{l}\text { sulfur-oxidizing } \\
\text { bacteria/granula } \\
r \text { activated } \\
\text { carbon }\end{array}$ & $\begin{array}{l}\text { COD } \\
\text { BODs } \\
\text { TOC } \\
\text { T-N }\end{array}$ & $\begin{array}{l}94.8 \% \\
\text { DOC } \\
\text { removal } \\
\text { Efficient }\end{array}$ & $\begin{array}{l}\text { Lin et } \\
\text { al.,1998 }\end{array}$ \\
\hline C-B & $\begin{array}{l}\text { THMFP } \\
\text { (trihalomethanes) }\end{array}$ & toxic & $\begin{array}{l}\mathrm{COD}= \\
2.8-4.2 \\
\mathrm{mg} / \mathrm{L}\end{array}$ & $\mathrm{O}_{3}$ & $\mathrm{BAC}^{\mathrm{x} v i 1}$ & $\begin{array}{l}\mathrm{DOC} \\
\mathrm{UV}_{260}\end{array}$ & Bad & $\begin{array}{l}\text { Nishijim et } \\
\text { al., } 1998\end{array}$ \\
\hline C-B & $\begin{array}{l}\text { 4,4- diaminoslibene-2,2- } \\
\text { disulfonic acid (DSD-acid) }\end{array}$ & $\begin{array}{l}\text { non- } \\
\text { biodegradable } \\
\text { bioresistant }\end{array}$ & $\begin{array}{l}\mathrm{COD}= \\
21900 \\
\mathrm{mg} / \mathrm{L}\end{array}$ & $\begin{array}{l}\text { Fenton's } \\
\text { reagent/ } \mathrm{O}_{3}\end{array}$ & & $\begin{array}{l}\mathrm{BOD} / \mathrm{COD} \\
\text { Color removal }\end{array}$ & Improved & $\begin{array}{l}\text { Yu et al., } \\
1998\end{array}$ \\
\hline $\mathrm{B}-\mathrm{C}$ & $\begin{array}{l}\text { Kraft bleaching process } \\
\text { Textile industry } \\
\text { wastewater }\end{array}$ & $\begin{array}{l}\text { toxic } \\
\text { refractory }\end{array}$ & $\begin{array}{l}\text { COD } \\
\text { textile= } \\
103 \mathrm{mg} / \mathrm{L} \\
\text { COD } \\
\text { Pulp= } \\
1029 \\
\mathrm{mg} / \mathrm{L}\end{array}$ & $\begin{array}{l}\text { Photocatalytict } \\
\mathrm{H}_{2} \mathrm{O}_{2}^{+} \\
\text {Fenton's }\end{array}$ & $\mathrm{BOD}_{5}$ & $\begin{array}{l}\text { COD } \\
\text { TOC } \\
\text { BOD }_{5} \\
\text { Color removal }\end{array}$ & $\begin{array}{l}\text { Potential } \\
\text { for reuse, } \\
\text { as } 97 \% \text { of } \\
\text { organics } \\
\text { were } \\
\text { removed }\end{array}$ & $\begin{array}{l}\text { Balcioglu } \\
\text { and } \\
\text { Arsalan, } \\
1998\end{array}$ \\
\hline $\mathrm{B}-\mathrm{C}$ & Olive mill wastewater & $\begin{array}{l}\text { Toxic } \\
\text { High inhibitory }\end{array}$ & $\begin{array}{l}\mathrm{COD}= \\
41.95 \\
\mathrm{~g} / \mathrm{dm}^{3}\end{array}$ & $\mathrm{O}_{3}$ & activated sludge & $\begin{array}{l}\text { COD } \\
\text { Total Aromatic } \\
\text { Total Phenolic } \\
\text { content }\end{array}$ & $\begin{array}{l}81.1 \% \\
\text { removed }\end{array}$ & $\begin{array}{l}\text { Benitez et } \\
\text { al., } 1999\end{array}$ \\
\hline $\mathrm{C}-\mathrm{B}$ & Olive mill wastewater & $\begin{array}{l}\text { toxic } \\
\text { high inhibitory }\end{array}$ & $\begin{array}{l}\mathrm{COD}= \\
34.05 \\
\mathrm{~g} / \mathrm{dm}^{3}\end{array}$ & $\mathrm{O}_{3}$ & activated sludge & $\begin{array}{l}\text { COD } \\
\text { Total Aromatic } \\
\text { Total Phenolic } \\
\text { content }\end{array}$ & $\begin{array}{l}84.6 \% \\
\text { removed }\end{array}$ & $\begin{array}{l}\text { Benitez et } \\
\text { al., } 1999\end{array}$ \\
\hline $\mathrm{B}-\mathrm{C}$ & Wine distillery wastewater & $\begin{array}{l}\text { toxicity } \\
\text { inhibitory }\end{array}$ & $\begin{array}{l}\mathrm{COD}= \\
27-29 \mathrm{~g} / \mathrm{L}\end{array}$ & $\mathrm{O}_{3} / \mathrm{H}_{2} \mathrm{O}_{2} / \mathrm{UV}$ & $\begin{array}{l}\text { aerobic } \\
\text { biological } \\
\text { reactor }\end{array}$ & COD & Effective & $\begin{array}{l}\text { Benitez et } \\
\text { al., } 1999\end{array}$ \\
\hline
\end{tabular}




\begin{tabular}{|c|c|c|c|c|c|c|c|c|}
\hline C-B & Domestic wastewater & $\begin{array}{l}\text { some refractory } \\
\text { compounds }\end{array}$ & $\begin{array}{l}\mathrm{BOD} / \\
\mathrm{COD}= \\
0.57\end{array}$ & $\mathrm{O}_{3}$ & activated sludge & $\begin{array}{l}\mathrm{BOD} / \mathrm{COD} \\
=0.69\end{array}$ & Good & $\begin{array}{l}\text { Beltran et } \\
\text { al., } 1999\end{array}$ \\
\hline $\mathrm{B}-\mathrm{C}$ & Domestic wastewater & $\begin{array}{l}\text { some refractory } \\
\text { compounds }\end{array}$ & $\begin{array}{l}\mathrm{BOD}= \\
162 \\
\mathrm{COD}= \\
286 \\
\end{array}$ & $\overline{\mathrm{O}_{3}}$ & $\begin{array}{l}\text { activated sludge } \\
\text { (mixed culture) }\end{array}$ & $\begin{array}{l}\text { BOD/COD } \\
\text { UV }\end{array}$ & Good & $\begin{array}{l}\text { Beltran et } \\
\text { al., } 1999\end{array}$ \\
\hline C-B & $\begin{array}{l}\text { Azo dyes and wool textile } \\
\text { wastewater }\end{array}$ & $\begin{array}{l}\text { non- } \\
\text { biodegradable }\end{array}$ & $\begin{array}{l}100 \\
\mathrm{ppm} / \mathrm{L}\end{array}$ & $\mathrm{TiO}_{2} / \mathrm{UV}$ & $\mathrm{BOD}_{5}$ & $\mathrm{BOD}_{5} / \mathrm{COC}$ & Good & $\begin{array}{l}\text { Chun and } \\
\text { Yizhong, } \\
1999 \\
\end{array}$ \\
\hline $\begin{array}{l}\text { C-B } \\
\text { two stages }\end{array}$ & Pulp and paper wastewater & $\begin{array}{l}\text { toxic } \\
\text { inhibitory }\end{array}$ & $\begin{array}{l}\mathrm{COD}= \\
400 \mathrm{mg} / \mathrm{L}\end{array}$ & $\mathrm{O}_{3}$ & $\begin{array}{l}\text { fixed bed } \\
\text { biofilm reactor }\end{array}$ & $\begin{array}{l}\text { COD } \\
\text { BOD }\end{array}$ & Efficient & $\begin{array}{l}\text { Helble et } \\
\text { al., } \\
1999 \\
\end{array}$ \\
\hline C-B & $\begin{array}{l}\text { Polycyclic aromatic } \\
\text { hydrocarbons in oil/water } \\
\text { emulsion }\end{array}$ & $\begin{array}{l}\text { biodegradability } \\
\text { of concentrated } \\
\text { PAH has not been } \\
\text { approved }\end{array}$ & - & $\begin{array}{l}\mathrm{O}_{3} \\
\text { (continuous) }\end{array}$ & $\begin{array}{l}\text { aerobic } \\
\text { biological } \\
\text { reactor }\end{array}$ & HPLC & Efficient & $\begin{array}{l}\text { Kornmuller } \\
\text { and } \\
\text { Wiesman, } \\
1999\end{array}$ \\
\hline B-C & Dye textile & $\begin{array}{l}\text { non- } \\
\text { biodegradable } \\
\text { toxic }\end{array}$ & $\begin{array}{l}\mathrm{COD}= \\
2000 \\
\mathrm{mg} / \mathrm{L}\end{array}$ & $\mathrm{TiO}_{2} / \mathrm{UV}$ & $\begin{array}{l}\text { intermittently } \\
\text { decanted } \\
\text { extended } \\
\text { aeration }\end{array}$ & $\begin{array}{l}\text { COD } \\
\text { BOD }\end{array}$ & Good & $\begin{array}{l}\text { Li and } \\
\text { Zhao, } \\
1999\end{array}$ \\
\hline$\overline{C-B}$ & $\begin{array}{l}\text { Textile wastewater } \\
\text {-Anthraquinone dyestuff } \\
\text {-Surfactant (softening } \\
\text { agent, anionic detergent) }\end{array}$ & $\begin{array}{l}\text {-inhibitory } \\
\text {-partially } \\
\text { biodegradable }\end{array}$ & $\begin{array}{l}\mathrm{COD}= \\
2154 \\
\mathrm{mg} / \mathrm{dm}^{3}\end{array}$ & $\mathrm{O}_{3} / \mathrm{UV} / \mathrm{H}_{2} \mathrm{O}_{2}$ & activated sludge & $\mathrm{EC}_{50}{ }^{\mathrm{xvili}}$ & Good & $\begin{array}{l}\text { Ledakowic } \\
\mathrm{z} \text { and } \\
\text { Gonera, } \\
1999\end{array}$ \\
\hline C-B & EDTA & $\begin{array}{l}\text { Non- } \\
\text { biodegradable }\end{array}$ & $100 \mathrm{mg} / \mathrm{L}$ & $\begin{array}{l}\text {-Fenton's } \\
\text { reagent } \\
-\mathrm{O}_{3}\end{array}$ & $\begin{array}{l}\text { biological } \\
\text { activated carbon }\end{array}$ & $\begin{array}{l}\text { BOD/COD } \\
\text { TOC }\end{array}$ & $\begin{array}{l}\text {-Fair } \\
\text {-Good }\end{array}$ & $\begin{array}{l}\text { Mochidizu } \\
\text { ki and } \\
\text { Takeuchi, } \\
1999 \\
\end{array}$ \\
\hline C-B & $\begin{array}{l}\text { Polyester manufacturing } \\
\text { plant }\end{array}$ & biorecalcitrant & $\begin{array}{l}\mathrm{COD}= \\
200000 \\
\mathrm{mg} / \mathrm{L}\end{array}$ & $\begin{array}{l}\mathrm{H}_{2} \mathrm{O}_{2} / \\
\text { Fenton's } \\
\text { reagent }\end{array}$ & activated sludge & $\begin{array}{l}\text { COD } \\
\text { BOD }\end{array}$ & $\begin{array}{l}80 \% \\
\text { removed }\end{array}$ & $\begin{array}{l}\text { Meric et } \\
\text { al., } 1999\end{array}$ \\
\hline
\end{tabular}




\begin{tabular}{|c|c|c|c|c|c|c|c|c|}
\hline C-B & $\begin{array}{l}\text { P-nitrotoluene- ortho- } \\
\text { sulfonic }\end{array}$ & biorecalcitrant & $\begin{array}{l}330 \\
\mathrm{mg} \mathrm{C} / \mathrm{L}\end{array}$ & $\begin{array}{l}\text { Fenton's } \\
\text { reagent }\end{array}$ & $\begin{array}{l}\text { fixed bed } \\
\text { reactor }\end{array}$ & $\begin{array}{l}\mathrm{COD} \\
\mathrm{BOC}\end{array}$ & Effective & $\begin{array}{c}\text { Pulgarin et } \\
\text { al., } 1999\end{array}$ \\
\hline C-B & $\begin{array}{l}\text { Pulp mill bleaching } \\
\text { effluent }\end{array}$ & $\begin{array}{l}\text { toxic } \\
\text { inhibitory }\end{array}$ & $\begin{array}{l}\mathrm{COD}= \\
2000 \\
\mathrm{mg} / \mathrm{L}\end{array}$ & $\mathrm{TiO}_{2}$ & activated sludge & $\begin{array}{l}\text { TOC } \\
\text { COD } \\
\text { BOD } \\
\text { AOX } \\
\text { Color }\end{array}$ & Efficient & $\begin{array}{l}\text { Yeber et } \\
\text { al., } \\
1999\end{array}$ \\
\hline C-B & $\begin{array}{l}\text { Nonylphenol ethoxylate } \\
\text { (NPE) }\end{array}$ & biorecalcitrant & - & $\begin{array}{l}\text { Fenton's } \\
\text { reagent }\end{array}$ & activated sludge & COD & $\begin{array}{l}\text { Depend on } \\
\text { oxidant } \\
\text { dose }\end{array}$ & $\begin{array}{l}\text { Kitis et al., } \\
1999\end{array}$ \\
\hline C-B & $\begin{array}{l}\text { Ethylene oxide/ propylene } \\
\text { oxide block copolymers }\end{array}$ & biorecalcitrant & - & $\begin{array}{l}\text { Fenton's } \\
\text { reagent }\end{array}$ & activated sludge & COD & Very good & $\begin{array}{l}\text { Kitis et } \\
\text { al., } 1999\end{array}$ \\
\hline C-B & $\begin{array}{l}\text { Non-surfactant compound } \\
\text { polypropylene glycon } \\
\text { (PPG) }\end{array}$ & biorecalcitrant & - & $\begin{array}{l}\text { Fenton's } \\
\text { reagent }\end{array}$ & activated sludge & COD & Very good & $\begin{array}{l}\text { Kitis et al., } \\
1999\end{array}$ \\
\hline $\mathrm{C}-\mathrm{B}$ & EO/PO Block copolymers & biorecalcitrant & - & $\mathrm{O}_{3} / \mathrm{H}_{2} \mathrm{O}_{2}$ & activated sludge & $\begin{array}{l}\text { DOC } \\
\text { COD }\end{array}$ & Good & $\begin{array}{l}\text { Kitis et al., } \\
2000\end{array}$ \\
\hline C-B & $\begin{array}{l}\text { Linear secondary } \\
\text { alcoholethyoxylates } \\
\text { (LSAE) }\end{array}$ & $\begin{array}{l}\text { partially to } \\
\text { biorecalcitrant }\end{array}$ & - & $\mathrm{O}_{3} / \mathrm{H}_{2} \mathrm{O}_{2}$ & activated sludge & $\begin{array}{l}\mathrm{DOC} \\
\mathrm{COD}\end{array}$ & Good & $\begin{array}{l}\text { Kitis et al., } \\
2000\end{array}$ \\
\hline C-B & $\begin{array}{l}\text { Alkylphenolethoxylates } \\
\text { (APE) }\end{array}$ & $\begin{array}{l}\text { Partially } \\
\text { Biorecalcitrant }\end{array}$ & - & $\mathrm{O}_{3} / \mathrm{H}_{2} \mathrm{O}_{2}$ & activated sludge & $\begin{array}{l}\mathrm{DOC} \\
\mathrm{COD}\end{array}$ & Good & $\begin{array}{l}\text { Kitis et al., } \\
2000\end{array}$ \\
\hline C-B & $\begin{array}{l}\text { Quaternary amine } \\
\text { surfactant } \\
\text {-alkyldimethylbenzyl } \\
\text { ammonium chloride } \\
\text { (Barquates) } \\
\text {-Dictyl-dimethyl } \\
\text { ammonium chloride } \\
\text { ( Bardoc LF) }\end{array}$ & $\begin{array}{l}\text { Biorecalcitrant } \\
\text { (enzymatic } \\
\text { deficiencies or } \\
\text { toxicological } \\
\text { properties) }\end{array}$ & $\begin{array}{l}\mathrm{COD}= \\
1000 \\
\mathrm{mg} / \mathrm{L}\end{array}$ & $\mathrm{UV} / \mathrm{H}_{2} \mathrm{O}_{2}$ & activated sludge & $\begin{array}{l}\mathrm{COD} \\
\mathrm{DOC}\end{array}$ & $\begin{array}{l}\text {-Very Good } \\
90 \% \\
\text { removal } \\
\text {-Little } \\
\text { effect } \\
15 \%\end{array}$ & $\begin{array}{l}\text { Adams and } \\
\text { Huzhikanni } \\
12000\end{array}$ \\
\hline
\end{tabular}




\begin{tabular}{|c|c|c|c|c|c|c|c|c|}
\hline C-B & $\begin{array}{l}\text { Agroindustrial \& Domestic } \\
\text { wastewater }\end{array}$ & $\begin{array}{l}\text { contains some } \\
\text { biorecalcitrant }\end{array}$ & $\begin{array}{l}\mathrm{COD}= \\
2443 \\
\mathrm{mg} / \mathrm{L}\end{array}$ & $\mathrm{O}_{3}$ & activated sludge & $\begin{array}{l}\text { COD } \\
\text { TOC } \\
\text { BOD } \\
\text { UV 254 } \\
\text { TKN }\end{array}$ & Effective & $\begin{array}{l}\text { Beltran et } \\
\text { al., } 2000\end{array}$ \\
\hline $\mathrm{B}-\mathrm{C}$ & $\begin{array}{l}\text { Black olive mill } \\
\text { wastewater }\end{array}$ & $\begin{array}{l}\text { toxic } \\
\text { inhabitant }\end{array}$ & $\begin{array}{l}\mathrm{COD}=67 \\
\mathrm{~g} / \mathrm{L}\end{array}$ & $\mathrm{O}_{3}$ & activated sludge & $\begin{array}{l}\text { COD } \\
T^{x x} \\
\end{array}$ & Good & $\begin{array}{l}\text { Heredia et } \\
\text { al., } 2000\end{array}$ \\
\hline C-B & $\begin{array}{l}\text { 2,3,7,8-tetrachloroibenzo - } \\
\text { p-dioxin }\end{array}$ & toxic & $\begin{array}{l}46 \mathrm{ug} / \mathrm{Kg} \\
\text { soil }\end{array}$ & Fenton's & activated sludge & TCDD $^{\mathrm{xxi}}$ conc. & Effective & $\begin{array}{l}\text { Kao and } \\
W u \\
2000\end{array}$ \\
\hline$\overline{C-B}$ & $\begin{array}{l}\text { Metobromuron/ } \\
\text { isoproturon }\end{array}$ & biorecalcitrant & - & $\begin{array}{l}\text { 1-Fe } \mathrm{Fe}^{3+1} \mathrm{H}_{2} \mathrm{O}_{2} \\
\text { 2-UV/FE } \\
\mathrm{H}_{2} \mathrm{O}_{2} \\
\text { 3-UV } \\
\text { 4-UV/TiO } / \\
\text { 5-UV/TiO } / \mathrm{TiO}_{2} / \\
\mathrm{H}_{2} \mathrm{O}_{2}\end{array}$ & $\begin{array}{l}\text { fixed bed } \\
\text { reactor }\end{array}$ & TOC & $\begin{array}{l}\text { 1-Bad } \\
\text { 2-Very } \\
\text { good } \\
\text { 3-Very bad } \\
\text { 4-Fair } \\
\text { 5-Good }\end{array}$ & $\begin{array}{l}\text { Parra et al., } \\
2000\end{array}$ \\
\hline C-B & Metobromuron isoproturon & $\begin{array}{l}\text { non- } \\
\text { biodegradable }\end{array}$ & $50 \mathrm{mg} / \mathrm{L}$ & Fenton's/ $\mathrm{TiO}_{2}$ & $\begin{array}{l}\text { fixed bed } \\
\text { reactor }\end{array}$ & $\begin{array}{l}\text { TOC } \\
\text { COD/BOD } \\
\mathrm{EC}_{50}\end{array}$ & $\begin{array}{l}\text { Effective } \\
95 \% \\
\text { removed }\end{array}$ & $\begin{array}{l}\text { Parra et al., } \\
2000\end{array}$ \\
\hline C-B & Pyrene & toxic & $\begin{array}{l}\text { Conc. }=1 \\
\mathrm{mg} / \mathrm{L}\end{array}$ & $\mathrm{O}_{3}$ & BOD & $\begin{array}{l}\text { COD } \\
\text { BOD } \\
\text { GC/FID } \\
\text { GC/MS } \\
\end{array}$ & Effective & $\begin{array}{l}\text { Zeng et al., } \\
2000\end{array}$ \\
\hline B-C & $\begin{array}{l}\text { Textile industry } \\
\text { wastewater }\end{array}$ & $\begin{array}{l}\text { toxic } \\
\text { recalcitrant }\end{array}$ & $\begin{array}{l}\mathrm{COD}= \\
325 \\
\mathrm{mg} / \mathrm{dm}^{3}\end{array}$ & $\begin{array}{l}-\mathrm{O}_{3} \\
-\mathrm{H}_{2} \mathrm{O}_{2} / \mathrm{UV}-\mathrm{C} \\
\text {-sequential } \\
\mathrm{O}_{3} / \mathrm{H}_{2} \mathrm{O}_{2} / \mathrm{UV}\end{array}$ & $\mathrm{BOD}$ & $\begin{array}{l}\text { TOC } \\
\text { COD } \\
\text { UV } \\
f_{B}^{\text {xxii }}\end{array}$ & $\begin{array}{l}\text { Overall } \\
\text { removal for } \\
\mathrm{O}_{3} \text { was } \\
60 \% \text { and it } \\
\text { was less for } \\
\text { the rest of } \\
\text { the } \\
\text { methods }\end{array}$ & $\begin{array}{l}\text { Arsalan and } \\
\text { Balcioglu, } \\
2001\end{array}$ \\
\hline C-B & Olive mill wastewater & $\begin{array}{l}\text { toxic } \\
\text { high inhibitory }\end{array}$ & $\begin{array}{l}\mathrm{COD}=95 \\
\mathrm{~g} / \mathrm{L}\end{array}$ & $\begin{array}{l}\text { Fenton's } \\
\text { reagent } \\
\text { Ozonation } \\
\end{array}$ & activated sludge & $\begin{array}{l}\text { COD } \\
\mathrm{BOD}_{5}\end{array}$ & Effective & $\begin{array}{l}\text { Heredia et } \\
\text { al., } 2001\end{array}$ \\
\hline
\end{tabular}




\begin{tabular}{|c|c|c|c|c|c|c|c|c|}
\hline $\begin{array}{l}\text { Filtration- } \\
\text { C-B }\end{array}$ & Polystyrene wastewater & toxic & $\begin{array}{l}\mathrm{COD}= \\
7000- \\
95000\end{array}$ & Fenton & activated sludge & $\begin{array}{l}\text { COD } \\
\text { BOD5 } \\
\text { BOD20 } \\
\text { SS }^{\text {xxiii }} \\
\end{array}$ & $\mathrm{COD}=150$ & $\begin{array}{l}\text { Bertanza et } \\
\text { al., 2001 }\end{array}$ \\
\hline C-B & Textile wastewater & toxic & $\begin{array}{l}\mathrm{COD}=17 \\
50 \mathrm{mg} / \mathrm{L}\end{array}$ & $\begin{array}{l}\text { 1-Fenton } \\
2-\mathrm{O}_{3} / \mathrm{H}_{2} \mathrm{O}_{2} \\
3-\mathrm{UV}\end{array}$ & activated sludge & $\begin{array}{l}\text { COD } \\
\text { BOD }_{5} \\
\text { TOC } \\
\end{array}$ & $\begin{array}{l}\text { 1-good } \\
2 \text {-bad } \\
\text { 3-good }\end{array}$ & $\begin{array}{l}\text { Bertanza et } \\
\text { al., } 2001\end{array}$ \\
\hline B-C-B & Polyester resin & toxic & $\begin{array}{l}\mathrm{COD}= \\
60000- \\
118000 \\
\mathrm{mg} / \mathrm{L}\end{array}$ & Fenton & activated sludge & $\begin{array}{l}\text { COD } \\
\mathrm{BOD}_{5} \\
\mathrm{BOD}_{20} \\
\text { Aldehydes }\end{array}$ & $\begin{array}{l}\mathrm{COD}=100 \\
\mathrm{mg} / \mathrm{l}\end{array}$ & $\begin{array}{l}\text { Bertanza et } \\
\text { al., } 2001\end{array}$ \\
\hline $\mathrm{B}-\mathrm{C}$ & $\begin{array}{l}\text { Distillery wastewater } \\
\text { (Cherry Stillage) }\end{array}$ & $\begin{array}{l}\text { some organics are } \\
\text { non- } \\
\text { biodegradable }\end{array}$ & $\begin{array}{l}\mathrm{COD}=1- \\
7 \mathrm{~g} / \mathrm{L}\end{array}$ & $\mathrm{O}_{3}$ & $\begin{array}{l}\text { activated sludge } \\
\text { with acclimated } \\
\text { culture }\end{array}$ & $\begin{array}{l}\text { COD } \\
\text { TOC } \\
\text { BOD }\end{array}$ & Good & $\begin{array}{l}\text { Beltran et } \\
\text { al., } 2001\end{array}$ \\
\hline C-B & $\begin{array}{l}\text { Textile wastewater } \\
\text { consisted of: } \\
\text {-Anionic detergent awiwaz } \\
\text { KG conc } \\
\text {-Softening agent Tetrapol } \\
\text { CLB } \\
\text {-Anthraquinone dyestuff- } \\
\text { acid blue } 40, \text { CI2125 }\end{array}$ & $\begin{array}{l}\text { little or non- } \\
\text { biodegradable } \\
\text { inhibitory, toxic }\end{array}$ & $\begin{array}{l}\mathrm{COD}= \\
2159 \\
\mathrm{mg} / \mathrm{L}\end{array}$ & $\begin{array}{l}\text { 1.UV/ } / \mathrm{H}_{2} \mathrm{O}_{2} \\
2 . \mathrm{UV} \\
3 . \mathrm{H}_{2} \mathrm{O}_{2} \\
4 . \mathrm{O}_{3}\end{array}$ & activated sludge & $\begin{array}{l}\mathrm{COD} \\
\mathrm{BOD}_{5} \\
\mathrm{DOC}\end{array}$ & $\begin{array}{l}\text { 1.Good } \\
\text { 2.Medium } \\
\text { 3.Fair } \\
\text { 4.Medium }\end{array}$ & $\begin{array}{l}\text { Ledakowic } \\
z \text { et al., } \\
2001\end{array}$ \\
\hline $\begin{array}{l}\text { B \& C } \\
\text { parallel }\end{array}$ & Textile & toxic & $\begin{array}{l}C O D= \\
860- \\
8000_{\mathrm{m} / \mathrm{L}}\end{array}$ & $\begin{array}{l}\mathrm{UV} / \mathrm{H}_{2} \mathrm{O}_{2} \\
\mathrm{UV} / \mathrm{O}_{3} \\
\mathrm{UV} / \mathrm{H}_{2} \mathrm{O}_{2} / \mathrm{O}_{3}\end{array}$ & $\begin{array}{l}\text { intensive } \\
\text { biological } \\
\text { treatment } \\
\end{array}$ & $\begin{array}{l}\text { COD } \\
\mathrm{BOD}_{5} \\
\text { Color } \\
\end{array}$ & $\mathrm{COD}_{\mathrm{f}}=0$ & $\begin{array}{l}\text { Lee et al., } \\
2001\end{array}$ \\
\hline C-B & $\begin{array}{l}\text { Dimethyl Sulphoxide } \\
\text { (DMSO) }\end{array}$ & low treatability & $800 \mathrm{mg} / \mathrm{L}$ & $\begin{array}{l}\text { Fenton's } \\
\text { reagent }\end{array}$ & activated sludge & $\begin{array}{l}\mathrm{BOD} / \mathrm{COD} \\
\mathrm{TOC}\end{array}$ & $\begin{array}{l}\text { Not to } \\
\text { effective in } \\
\text { compare to } \\
\text { cost }\end{array}$ & $\begin{array}{l}\text { Park et al., } \\
2001\end{array}$ \\
\hline C-B & $\begin{array}{l}\text { 5- amino-6-methyl-2- } \\
\text { benzimidazolone }\end{array}$ & Biorecalcitrant & $\begin{array}{l}\mathrm{COD}= \\
18105 \\
\mathrm{mg} / \mathrm{L}\end{array}$ & $\begin{array}{l}\text { 1. } \mathrm{Fe}^{3+} / \mathrm{H}_{2} \mathrm{O}_{2} \\
\text { 2. } \mathrm{Fe}^{3+} / \mathrm{H}_{2} \mathrm{O}_{2} / \\
\mathrm{UV}\end{array}$ & $\begin{array}{l}\text { fixed bed } \\
\text { reactor }\end{array}$ & $\begin{array}{l}\text { DOC } \\
\text { AMBI xiv conc. } \\
\text { COD } \\
\mathrm{BOD}_{5}\end{array}$ & $\begin{array}{l}\text { Only (2) } \\
\text { was } \\
\text { effective } \\
\text { by } 80 \%\end{array}$ & $\begin{array}{l}\text { Sarria et } \\
\text { al., } 2001\end{array}$ \\
\hline
\end{tabular}




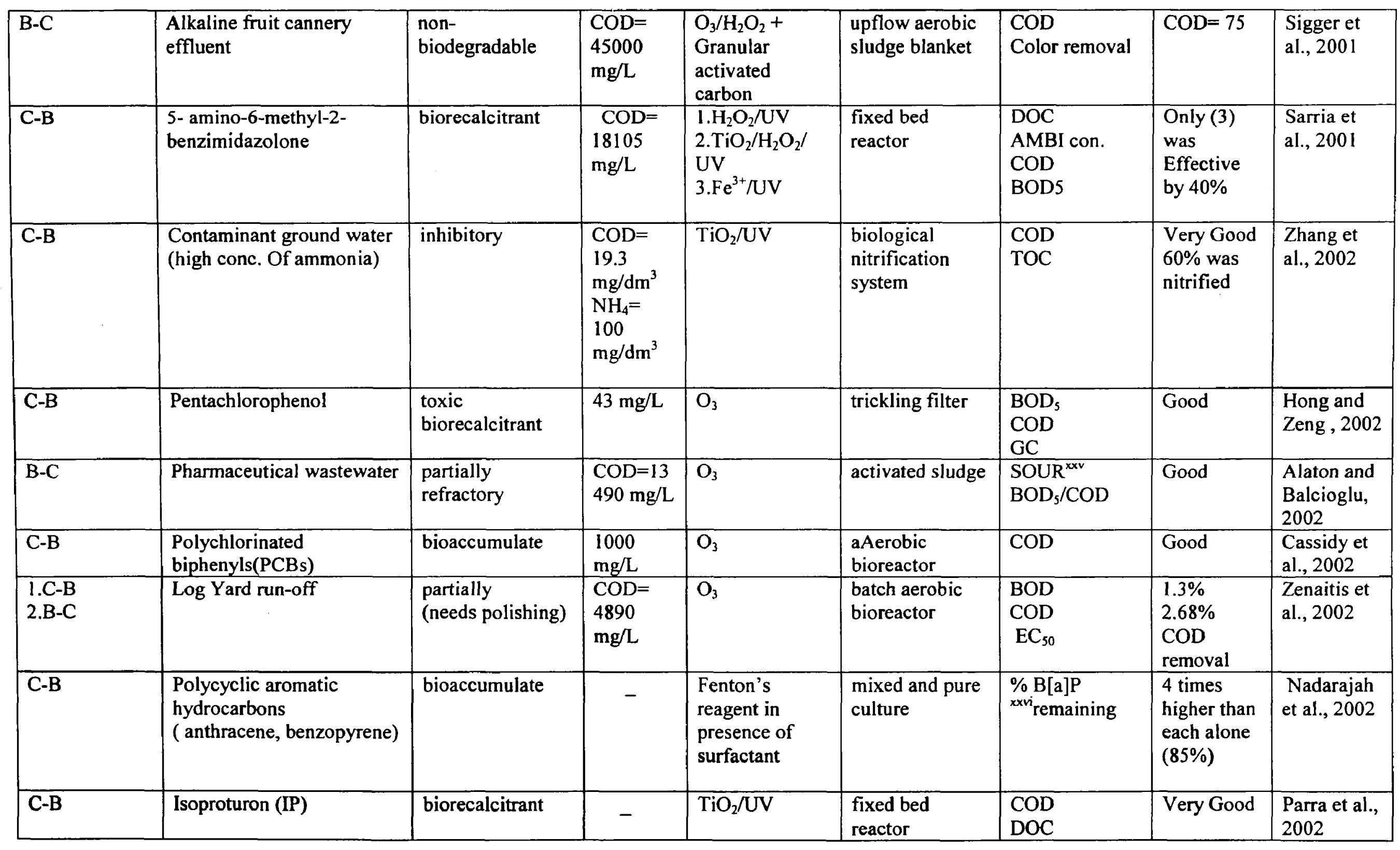




\begin{tabular}{|c|c|c|c|c|c|c|c|c|}
\hline C-B & $\begin{array}{l}\text { P-nitrotoluene- ortho- } \\
\text { sulfonic }\end{array}$ & biorecalcitrant & - & $\begin{array}{l}\mathrm{TiO}_{2} \text { (coaxial } \\
\text { reactor) } \\
\mathrm{Fe}^{3+} \text { (coil } \\
\text { reactor) }\end{array}$ & $\begin{array}{l}\text { fixed bed } \\
\text { reactor }\end{array}$ & $\begin{array}{l}\text { COD } \\
\text { BOC }\end{array}$ & Effective & $\begin{array}{l}\text { Sarria et } \\
\text { al., } 2002\end{array}$ \\
\hline$\overline{C-B}$ & $\begin{array}{l}\text { Metobromuron } \\
\text { Isoproturun }\end{array}$ & biorecalcitrant & - & $\begin{array}{l}\mathrm{TiO}_{2} \text { (coaxial } \\
\text { reactor) } \\
\mathrm{Fe}^{3+} \text { (coil } \\
\text { reactor) }\end{array}$ & $\begin{array}{l}\text { fixed bed } \\
\text { reactor }\end{array}$ & $\begin{array}{l}\overline{C O D} \\
\mathrm{BOC}\end{array}$ & Effective & $\begin{array}{l}\text { Sarria et } \\
\text { al., } 2002\end{array}$ \\
\hline $\begin{array}{l}\text { C-B } \\
\text { multistage }\end{array}$ & $\begin{array}{l}\text { Drinking water containing } \\
\text { DOM }\end{array}$ & $\begin{array}{l}\text { some refractory } \\
\text { compounds }\end{array}$ & $\begin{array}{l}\text { DOC }= \\
9.3 \mathrm{mg} / \mathrm{L}\end{array}$ & $\begin{array}{l}\mathrm{O}_{3} \\
\mathrm{O}_{3} / \mathrm{H}_{2} \mathrm{O}_{2}\end{array}$ & $\begin{array}{l}\text { biological } \\
\text { activated carbon }\end{array}$ & $\overline{\mathrm{DOC}}$ & $\begin{array}{l}\text { Bad } \\
\text { Effective }\end{array}$ & $\begin{array}{l}\text { Fahmi et } \\
\text { al., } 2003\end{array}$ \\
\hline $\begin{array}{l}\text { C-B } \\
\text { Multi-stage }\end{array}$ & $\begin{array}{l}\text { 1-Secondary effluent } \\
\text { containing (DOM) } \\
\text { 2-Humic substrate }\end{array}$ & $\begin{array}{l}\text { some } \\
\text { biorefractory } \\
\text { organics }\end{array}$ & $\begin{array}{l}\mathrm{DOC}=10 \\
\mathrm{mg} / \mathrm{L} \text { for } \\
\text { both }\end{array}$ & $\mathrm{O}_{3}$ & $\begin{array}{l}\text { common } \\
\text { biological } \\
\text { process }\end{array}$ & DOC & $\begin{array}{l}\text { 1-Bad } \\
\text { 2-Good }\end{array}$ & $\begin{array}{l}\text { Nishijima } \\
\text { et al., } 2003\end{array}$ \\
\hline C-B & $\begin{array}{l}\text { Cibacron brilliant yellow } \\
\text { 3G-P }\end{array}$ & biorecalcitrant & $100 \mathrm{mg} / \mathrm{L}$ & $\begin{array}{l}\text { Photocatalytic } \\
\text { reactor }\end{array}$ & $\begin{array}{l}\text {-Conventional } \\
\text { BOD } \\
\text {-respiromertric } \\
\text {-aerobic } \\
\text { treatment }\end{array}$ & $\begin{array}{l}\text { BOD } \\
\text { COD } \\
\text { OUR }^{\text {xxvii }}\end{array}$ & $\begin{array}{l}\text { no } \\
\text { improveme } \\
\text { nt was } \\
\text { observed in } \\
\text { biodegrada } \\
\text { bility }\end{array}$ & $\begin{array}{l}\text { Aye et al., } \\
2003\end{array}$ \\
\hline
\end{tabular}

\footnotetext{
' The order of the reactors is biological-chemical-biological

ii Biological Oxygen Demand

iii Chemical Oxygen Demand

iv Dissolved Organic Carbon

"The order of the reactors is biological-chemical

vi The order of the reactors is chemical-biological

${ }^{\text {vii }}$ Adsorbable organic halogen

viii Tannery substream Beam House wastewater

ix Tan-yard wastewater

${ }^{x}$ UV absorbance at specific wavelength

${ }^{x}$ BOD after $T$ days

xii trihalomethane formation potential

xiii Total Organic Carbon

${ }^{\text {xiv }}$ Mixed Liquor Suspended Solid
} 
xv Sludge Volume Index

xvi Total Nitrogen

xvii Biological Activated Carbon

vviii acute toxicity

${ }^{x i x}$ Total Kjeldhal Nitrogen

${ }^{x x}$ Total Phosphorous

xxi 2,3,7,8-tetrachloroibenzo-p-dioxin

xxii biodegradability factor

xxiii Suspended Solids

xxiv 5- amino-6-methyl-2- benzimidazolone

${ }^{x x v}$ Specific Oxygen Uptake Rate

${ }^{x x}$ benzo[a]pyrene

xxvii Oxygen Uptake Rate 


\subsection{Concentration of Oxidants in AOPs}

Most of the studies show that there is an optimum oxidant dose rate to remove the maximum amount of pollutants with the lesser oxidant consumption. It has been shown that increasing the oxidant dose in Fenton reaction increases both the extent and the rate of the biodegradation (Parra et al., 2000). The increase in $\mathrm{H}_{2} \mathrm{O}_{2}$ concentration as a strong electron acceptor also had inhibitory effect on the degradability of herbicides (Parra et al., 2000). The concentration of an optimal $\mathrm{H}_{2} \mathrm{O}_{2}$ /pollutant molar ratio between 10 and 100 (mole $\mathrm{H}_{2} \mathrm{O}_{2}$ )/(mole pollutant) had been proposed by other researchers (Parra et al., 2002). It was also reported that the addition of $32 \mathrm{~cm}^{3} \mathrm{H}_{2} \mathrm{O}_{2}$ to $1 \mathrm{dm}^{3}$ textile wastewater was equal to $80 \%$ decrease in the inhibition effect (Ledakowicz and Gonera, 1999). This was probably due to the auto-oxidation of $\mathrm{H}_{2} \mathrm{O}_{2}$ into $\mathrm{O}_{2}$ and $\mathrm{H}_{2} \mathrm{O}$, and recombination of ${ }^{\circ} \mathrm{OH}$ by means of $\mathrm{H}_{2} \mathrm{O}_{2}$ according to the following reactions:

$$
\begin{aligned}
& 2 \mathrm{H}_{2} \mathrm{O}_{2} \rightarrow 2 \mathrm{H}_{2} \mathrm{O}+\mathrm{O}_{2} \\
& \mathrm{H}_{2} \mathrm{O}_{2}+{ }^{\circ} \mathrm{OH} \rightarrow \mathrm{H}_{2} \mathrm{O}+{ }^{\circ} \mathrm{O}_{2} \mathrm{H} \\
& k=3.3 \times 10^{7}(\mathrm{~mol} \cdot \mathrm{s})^{-1}
\end{aligned}
$$

The excess of $\mathrm{H}_{2} \mathrm{O}_{2}$ reacts with ${ }^{\circ} \mathrm{OH}$, competing with pollutants and, hence, decreasing the efficiency of the treatment (Ledakowicz and Gonera, 1999).

\subsection{Treatment Time}

The information about the toxicity and the biodegradability of a compound treated by AOPs allows us to determine an optimal treatment time in the AOPs reactor of the coupled system. It has been observed that the toxicity was increased at the beginning of the treatment of isoproturon by AOP followed by a sharp decrease in the toxicity (Parra et al., 2002). It has been indicated that the intermediates formed during the beginning of the treatment are more toxic than the initial compounds. Therefore, the time should be the best compromise between the efficiency of the chemical reactor and its cost. The shorter reaction time avoids the high electrical cost of the reaction. At longer photo-treatment time, the photochemical efficiency is improved by the unnecessary 
photo-degradation of pollutants which are biologically degraded. However, the overall efficiency remains almost constant. This implies higher energy consumption without beneficial effect, as about $60 \%$ of the total operational cost is electricity (Parra et al., 2002). However, if the reaction time is too short, the intermediates remaining in the system could still have toxicological or biorecalcitrant effects.

Partial oxidation parameters, which correlated with subsequent biodegradation, have been developed (Jochimsen and Jekel, 1997). These parameters set the optimal point for the oxidative treatment. A combination of dissolved organic carbon (DOC) and chemical oxygen demand (COD) concentrations at different times allows differentiating between the oxidation effects of mineralization (total oxidation) and partial oxidation. COD-reduction through partial oxidation is estimated by the following equations (Jochimsen and Jekel, 1997):

$$
C O D_{\text {partuxi }}=\left(\frac{C O D_{0}}{D O C_{0}}-\frac{C O D_{1}}{D O C_{1}}\right) \times D O C_{1}
$$

where $\mathrm{COD}_{\text {partoxi }}$ is partial $\mathrm{COD}$ reduction, $\mathrm{COD}_{\mathrm{o}}$ and $\mathrm{DOC}_{\mathrm{o}}$ represent the initial concentration of the wastewater, and $\mathrm{COD}_{1}$ and $\mathrm{DOC}_{1}$ represent the final concentrations. The degree of COD-removal through partial oxidation is given by Equation (2.8), where $\alpha_{C O D_{\text {pmuxi }}}$ represents the degree of COD removal (Jochimsen and Jekel, 1997):

$$
\alpha_{(Y))_{\text {menturi }}}=1-\frac{C O D_{\text {martoxi }}}{C O D_{0}}
$$

The degree of effective partial oxidation ( $\mu_{C O D_{\text {pemaxi }}}$ ) represents the relationship between partial and total oxidation as follows:

$$
\mu_{(C O)_{\text {prmaxi }}}=\frac{C O D_{\text {pamaxi }}}{C O D_{0}-C O D_{1}}
$$


To compare the electivity of oxidative and biological DOC-removal, the difference between the biodegradable DOC and the DOC after chemical oxidation related to initial DOC is estimated by the following equation (Jochimsen and Jekel, 1997):

$$
\alpha_{D O C_{\text {itow }}}=\frac{D O C_{\text {oxi }}-D O C_{b i o}}{D O C_{o}}
$$

where $\alpha_{D X C_{\text {Mlo }}}, \mathrm{DOC}_{\mathrm{oxi}}, \mathrm{DOC}_{\mathrm{bio}}$, and $\mathrm{DOC}_{\mathrm{o}}$ are the electivity of oxidative and biological DOC-removal, oxidative DOC-removal, biological DOC-removal, and initial DOC, respectively.

\subsection{Influence of pH on Degradability}

Primary parameters such as temperature and $\mathrm{pH}$ have significant effects on the oxidation pathway and the products. It has been found that the best $\mathrm{pH}$ for the Fenton reaction is in the range of 3-5. It is also observed that in Fenton treatment, the optimum $\mathrm{pH}$ is based on TOC and COD removal efficiency (Park et al., 2001). It has also been shown that the best $\mathrm{pH}$ for the degradation of nonionic surfactants is 3 (Adams et al., 1997). However, in the next step, precipitation of oxidized iron $\mathrm{Fe}(\mathrm{OH})_{3}$ has to be performed by adjusting $\mathrm{pH}$ to 7-8. It was also observed that the best $\mathrm{pH}$ for degrading polycyclic aromatic hydrocarbons by Fenton reaction was 4 (Nadarajah et al., 2002). The same $\mathrm{pH}$ range was approved in other studies (Kao and $\mathrm{Wu}, 2000$; Mochidzuki and Takeuchi, 1999; Parra et al., 2000; and Bertanza et al., 2001). It was observed that the $\mathrm{pH}$ value was an important parameter for the type of ozone reaction and oxidation products formed during ozonation (Kornmuller and Wiesmann, 1999 ). At $\mathrm{pH} \leq 8$, the direct reaction mechanism took place (addition of the ${ }^{\circ} \mathrm{OH}$ to double bond). At alkaline condition, no elimination could be achieved as ozone decayed to hydroxyl radicals. Chain reaction might lead to other radicals and consequently dissolved ozone was diminished. Also at alkaline condition, it was assumed that a great influence of fluid-fluid ozone mass transfer existed. Therefore, it was expected that molecular ozone was the major oxidant at acidic $\mathrm{pH}$. Whereas, a faster and less selective ${ }^{\circ} \mathrm{OH}$ oxidation became dominant at $\mathrm{pH}>7$ 
as $\mathrm{OH}$ accelerated ozone decomposition, but it resulted to a slow and insufficient removal (Alaton and Balciglu, 2002). It was also observed that at $\mathrm{pH} \mathrm{3,} \mathrm{COD} \mathrm{removal}$ was rather slow but 3 times higher in the presence of $U V$ at acidic $\mathrm{pH}$. This might be due to the selectivity of ozonation for UV absorbance at acidic $\mathrm{pH}$ as well as the increased scavenging effect of the high bicarbonate alkalinity present in pharmaceutical wastewater at $\mathrm{pH}$ 8. Aromatic compounds and unsaturated double bonds were selectively attacked at alkaline $\mathrm{pH}$. Therefore, UV-sensitive wastewater components were removed at alkaline $\mathrm{pH}$ faster than those at acidic $\mathrm{pH}$. Moreover, at high $\mathrm{pH}$ the less selectivity of ${ }^{\circ} \mathrm{OH}$ radicals were formed as a result of rapid ozone decomposition. It is known that inorganic and organic compounds in pharmaceutical effluent readily scavenge ozone. Hence, more UV-sensitive parent compounds are removed at alkaline $\mathrm{pH}$ than those at acidic $\mathrm{pH}$ (Alaton and Balciglu, 2002). The final conversion of organic matter in the wine distillery wastewater, post-treated by ozonation, was defined as follows (Benitez et al., 1999):

$$
X_{s}=\frac{S_{0}-S_{f}}{S_{0}}
$$

where $\mathrm{X}_{\mathrm{s}}, \mathrm{S}_{\mathrm{o}}$, and $\mathrm{S}_{\mathrm{f}}$ are total substrate removal, substrate initial concentration (gCOD/L), and substrate final concentration (g COD/L) measured after 6 hours of reaction, respectively. It was observed that the conversion was increased when the $\mathrm{pH}$ was increased to 9 by combination of UV radiation and $\mathrm{H}_{2} \mathrm{O}_{2}$ with the ozonation. It can be concluded that the higher $\mathrm{pH}$ and ozonatoion rate lead to an improvement of the oxidation process by $\mathrm{UV}$ and $\mathrm{H}_{2} \mathrm{O}_{2}$. It was also observed that $\mathrm{pH}$ was an important factor for improving ozonation rate. It was found that when $\mathrm{pH}$ of pre-ozonation changes from 2 to 7 and 9, the percentage of convergence of COD (defined by Equation (2.12)) was increased by $23 \%$ according to the following equation:

Percentage of convergence of $\mathrm{COD}=\left[\left(\mathrm{COD}_{0}-\mathrm{COD}\right) / \mathrm{COD}_{0}\right] \times 100$

where subscript o indicates the value for non-ozonated wastewater. 
However, an increase in biological fraction of wastewater is higher at lower $\mathrm{pH}$. By changing $\mathrm{pH}$ from 9 to 2, the biological fraction of wastewater is increased from $25 \%$ to $36 \%$ (Beltran et al., 1997). These results can be explained by the way ozone attack the compounds present in water. As the hydroxyl radical concentration is increased by increasing $\mathrm{pH}$ (decomposition of ozone into free radicals), more reduction in COD was achieved. During the initial periods of ozonation, there was no accumulation of dissolved ozone in water, which indicated that fast and direct ozone reactions was developed (Beltran et al., 1997). It was also observed that the $\mathrm{pH} 9$ had the best effect on $\mathrm{COD} / \mathrm{COD}_{\mathrm{o}}$ during ozonation. But $\mathrm{pH} 2$ had the least effect on the ratio of $\mathrm{COD}$ at any time per initial $\mathrm{COD}\left(\mathrm{COD} / \mathrm{COD}_{\mathrm{o}}\right)$. Therefore, it is realized that ozonation at $\mathrm{pH} 2$ cannot decrease the concentration of $\mathrm{COD}$ in the wastewater as much as the oznation at $\mathrm{pH} 9$ (Beltran et al., 1997). It was also observed that by removing the carbonates present in municipal wastewater (radical scavengers) and increasing $\mathrm{pH}$ from 2 to 9 , the percentage convergence of COD varied from $25.5 \%$ to $36 \%$ during ozonation. The absence of radical scavengers led to an increase in total degradation of wastewater (Beltran et al., 1997). Moreover, it was reported that when tetrahydrofuran and 1,4-dioxane were degraded by photocatalytic process in the presence of carbonate and bicarbonate, the degradation rate of 1,4-dioxane was decreased, but a small increase in the degradation rate of tetrahydrofuran was observed. This increase was believed to be due to the increase in the $\mathrm{pH}$ during the reaction (Mehrvar et al., 2001).

\subsection{Influence of Temperature on the Degradability of Pollutants}

For oil emulsion wastewater oxidized in batch experiment by ozonation, no significant temperature changes have been reported (Beltran et al., 2001). Increasing temperature increases the reduction of $\mathrm{COD}$ in a process utilizing Fenton's reagent according to Equation (2.13), in which $\mathrm{k}^{\prime}$ is the rate constant [ $\left.\mathrm{Lmol}^{-1} \mathrm{~min}^{-1}\right]$ (Beltran et al., 2001).

$$
k^{\prime}=1.43 \times 10^{8} \exp (-5334 / T)\left[\mathrm{Fe}^{2+}\right] \quad \mathrm{Lmol}^{-1} \mathrm{~min}^{-1}
$$


In the ozonation of the black olive mill, changing the temperature from $10-20^{\circ} \mathrm{C}$ decreased the concentration of the pollutants by $43 \%$. However, the change in the temperature from $20-30^{\circ} \mathrm{C}$ caused an increase in the concentration of pollutants by $55 \%$. This could be because when the temperature increases, the kinetic rate constants increase, whereas, the ozone solubility in water decreases. By increasing $\mathrm{pH}$, ozone autodecomposition in water increases, therefore, the ozone concentration in the liquid decreases (Beltran et al., 2000). No significant effect was observed between $20-30^{\circ} \mathrm{C}$ for the ozonation of urban wastewater. As a result, it is not convenient to reach temperatures for ozonation above ambient conditions (Beltran et al., 1997).

\subsection{Measurement Parameters in Biodegradability}

Total organic carbon (TOC) measures the amount of organics, which are depleted to $\mathrm{CO}_{2}$ during chemical oxidation. In the case of combined AOPs and biological processes, little TOC reduction in the chemical step is desired because mineralization is not intended to achieve in chemical process.

COD is a parameter that measures the oxygen demand necessary for the chemical oxidation of the organics. It can also show the continuous evolution of pollutants during the treatment processes (Beltran et al., 2000).

$\mathrm{X}_{\mathrm{COD}}$ evaluates the removal of organic matter during the AOP as is shown in Equation (2.14) (Benitez et al., 1999a):

$$
X_{C O D}=\frac{C O D_{0}-C O D_{f}}{C O D_{v}} \times 100
$$

where $\mathrm{X}_{\mathrm{COD}}, \mathrm{COD}_{\mathrm{o}}$, and $\mathrm{COD}_{\mathrm{f}}$ are total $\mathrm{COD}$ removal, initial $\mathrm{COD}$, and final $\mathrm{COD}$ [mg/L], respectively.

COD/TOC ratio shows how chemical substrates in the effluent become more oxidized. Lower ratio shows higher degree of oxidation. Samples with smallest 
COD/DOC ratio after application of AOP have the largest biodegradable fraction (Parra et al., 2000).

$\mathrm{BOD}_{5}$ test is an index for the potential extent of a biological oxidation step. Increase in the values of BOD/TOC can indicate either reduction in toxicity or improvement on the biodegradability of the solution. Fast but not reliable biodegradability tests are short line BOD or OUR (oxygen uptake rate) in a respirometer.

To predict the activated sludge response to prompt changes in pollution composition, it is shown that parameters such as $\mathrm{COD}$ and $\mathrm{BOD}_{5}$ used to evaluate the operating performance of the biological processes are often insufficient (Alaton and Balciglu, 2002). Meanwhile, the toxicity tests are very time consuming and expensive. The aerobic bacteria toxicity test measures the oxygen uptake rate (OUR) of the toxicant, but it may also identify the inhibition rate of the aerobic microorganism exposed to the toxicant.

Average oxidation state (AOS) is another parameter that can be considered as another degradability measurement parameter during the treatment of the organics in a chemical reactor. It is defined as (Parra et al., 1999):

$$
A O S=\frac{4(T O C-C O D)}{T O C}
$$

where COD is chemical oxygen demand, and TOC is total organic carbon. AOS takes values between +4 for $\mathrm{CO}_{2}$ (the most oxidized state of $\mathrm{C}$ ) and -4 for $\mathrm{CH}_{4}$ (the most reduced state of $\mathrm{C}$ ) when the stabilization of this parameter is reached. The photo-treated solution may be considered as biocompatible if only the chemical nature of intermediates is considered.

$\mathrm{F} / \mathrm{M}$ (ratio of food to microorganisms) is also another important parameter that helps finding the most cost effective treatment. Low F/M implies higher retention time or higher mixed liquor volatile suspended solids (MLVSS) concentration, which negatively affects the cost of the process. Specific oxygen uptake rate (SOUR) also 
becomes slower as F/M decreases, but sludge volume index (SVI), which is the ratio of settled sludge volume $(\mathrm{mL} / \mathrm{L})$ to suspended solids $(\mathrm{mg} / \mathrm{L})$, increases remarkably. Increasing $\mathrm{F} / \mathrm{M}$ ratio causes a decrease in MLVSS or hydraulic retention time (HRT), which leads to a decrease in COD and BOD reduction. High F/M ratio promotes a log growth of biomass that leads to low BOD removal efficiency, poor settling sludge, and high effluent solids concentration (Beltran et al., 1999). F/M ratio must be adjusted to achieve high organic conversion and cost minimization.

Relative changes in the biodegradability of wastewater samples during advanced oxidation time are express follows (Arsalan and Balciglu, 2001):

$$
f_{B}=\frac{B O D_{s, l}\left(C O D_{t}\right)^{-1}}{B O D_{s, 0}\left(C O D_{0}\right)^{-1}}
$$

where $\mathrm{f}_{\mathrm{B}}, \mathrm{COD}_{\mathrm{o}}, \mathrm{COD}_{\mathrm{t}}, \mathrm{BOD}_{5, \mathrm{l}}$, and $\mathrm{BOD}_{5, \mathrm{o}}$ are biodegradability factor, initial $\mathrm{COD}$, COD at time t, 5-day BOD at time $t$, and 5-day BOD at time $t=0$, respectively.

\subsection{Microorganism's Adaptation}

The concentration of substrates plays a significant role in the biodegradability of the wastewater (Adams et al., 1997). Sometimes acclimation is necessary to adapt microorganisms to different conditions such as $\mathrm{pH}$ and temperature (Beltran et al., 1999). Adaptation can improve the sludge settling characteristic and OUR. The lag time gives an indication of the time required for the unacclimated biomass to acclimate to the organic substrate. The rate of degradation provides a relative measure for the ease of biodegradation after the biomass is acclimated. Some of the pollutants are biodegradable under controlled laboratory conditions following acclimation of a suitable microbial group. However, it is not possible to apply specific acclimated microorganism to wastewater during conventional treatment plants. It was observed that COD removal rate for the distillery wastewater by biological oxidation at $\mathrm{pH} 7$ was much higher than that at pH 4 with nonacclimated microorganisms (Bertlan et al., 2001). The microorganisms 
had low activity at acidic $\mathrm{pH}$, however, after a period of acclimation, the biological activity started to improve. Regarding the sludge settleability, sludge volume index (SVI) of the acidic wastewater with acclimated microorganisms was much lower than $100 \mathrm{mg} / \mathrm{l}$ (SVI should be between $50-150 \mathrm{mg} / \mathrm{L}$ for a good performance of the activated sludge treatment plant).

\subsection{Removal of Residual Oxidant}

As $\mathrm{H}_{2} \mathrm{O}_{2}$ is known to be bactericides and inhibitor in the bacteria activity, it should be removed from the pre-treated solution not only to make it suitable for following biological step, but also to stop the oxidation. By choosing an optimal time, $\mathrm{H}_{2} \mathrm{O}_{2}$ can be removed from the solution completely. Also $\mathrm{H}_{2} \mathrm{O}_{2}$ less than $200 \mathrm{mg} / \mathrm{L}$ may be removed effectively by addition of catalase and keeping the solution for 2 hours without stirring it (Ito et al., 1998). It has been shown that $\mathrm{FeCl}_{2}$ is able to eliminate the residual $\mathrm{H}_{2} \mathrm{O}_{2}$ (Andreozzi et al., 1998).

\subsection{Optimum Situation for Biological Post-Treatment}

Theoretical favorable conditions for the bioreactors are in the presence of cosubstrates and adapted bacteria, strict $\mathrm{pH}$ control, temperature, and aeration for aerobic reactors. Neutralization of the pre-treated solution is necessary as usually the acidity of effluent from the chemical reactor is very high. During the biological post-treatment, the $\mathrm{pH}$ should be maintained between 6.5-7.5. After a photo-chemical stage, the effluent may enter into a biological reactor for further treatment if the initial bio-recalcitrant compounds, the inhibitory intermediates, and the residual oxidant, or $\mathrm{H}_{2} \mathrm{O}_{2}$ have been eliminated and the toxicity test has been carried out.

\subsection{Mathematical Models of Chemical and Biological Reactions}

A combined process usually consists of a chemical reactor followed by a bioreactor. In the chemical reactor depending on the type of AOPs and the order of the reactions, the compounds could be degraded to a certain point and then it will enter into the bioreactor. In order to be able to gain the maximum benefit from this integration, the residence time of the wastewater in each reactor should be optimized. Moreover, the 
initial design of the reactors can be improved by optimization; therefore, the least energy usage and maximum efficiency can be achieved while minimizing the cost. The objective function is the total cost (defined as cost function) and has a close relation with the sum of the liquid phase residence time in chemical and biological reactors which was proposed to be held constant to give a design constraint as follows (Ollis and Scott, 1996):

$\Theta_{\mathrm{C}}+\Theta_{\mathrm{B}}=\Theta_{\mathrm{G}}=$ constant

where $\Theta_{C}, \Theta_{B}$, wnd $\Theta_{\mathrm{G}}$ are chemical, biological, and overall residence time, respectively.

In addition to the objective function, the equality constraints (equations) and the inequality constraints (inequalities) have to be modeled. However, determining the mentioned expressions needs an accurate analysis of the process and well-known physical principles (mass balances, energy balances, empirical relations and implicit concepts). If all of the above expressions are available, a suitable optimization technique could be applied for the whole process. By minimizing the total residence time in both reactors, the optimal residence time in chemical reactor (the most cost consuming treatment) can identify the best residence time in the bioreactor. Moreover, the total efficiency can be defined as (Ollis and Scott, 1996):

$$
\begin{aligned}
& \eta_{C}=\left(C_{A 0}-C_{A C}-C_{S C}\right) / C_{A 0} \\
& \eta_{B}=\left(C_{S C}-C_{S B}\right) / C_{A 0} \\
& \eta_{G}=\left(C_{A 0}-C_{S B}-C_{A C}\right) / C_{A 0}=\eta_{C}+\eta_{B}
\end{aligned}
$$

where $\eta$ is performance efficiency for chemical $\left(\eta_{C}\right)$, biological $\left(\eta_{B}\right)$, and overall system or global efficiency $\left(\eta_{\mathrm{G}}\right) . \mathrm{C}_{\mathrm{A} 0}, \mathrm{C}_{\mathrm{AC}}$, and $\mathrm{C}_{\mathrm{SC}}$ are the inlet concentration of compound $\mathrm{A}$, outlet concentration of compound $\mathrm{A}$, and outlet concentration of intermediate $\mathrm{S}$ in the chemical reactor, respectively. $\mathrm{C}_{\mathrm{SB}}$ is the outlet concentration of intermediate $\mathrm{S}$ in the bioreactor. The total efficiency can be considered as an equality constraint. Defining a desired efficiency for the whole system can restrict the objective function to give an 
answer within its constraints. The effort of most of the researchers working in this area is to develop mathematical models to identify the changes in the concentration of the substrate with respect to time for both chemical and biological reactions, which give the retention time for a compound in each reactor in order to reach to the desired concentration.

\subsection{Background (Linear Alkylbenzene Sulfonate)}

LAS was first introduced in 1960 as a biodegradable compound to substitute nonbiodegradable compounds in detergents. It is produced by sulfonation of linear alkylbenzene with sulfur trioxide. Detergents contain 5-25\% LAS, and the length of its chain ranges from $\mathrm{C}_{10}$ to $\mathrm{C}_{14}$ (WHO, 1996). The concentration of LAS in the influent of domestic wastewater treatment plants was reported in the range of $1 \mathrm{mg} / \mathrm{L}$ to $5 \mathrm{mg} / \mathrm{L}$ (Kaiser et al., 1997). It has also been reported that the influent and effluent concentrations of LAS in the activated sludge process from ten U.S. domestic wastewater treatment plants range from 3.0-7.7 $\mathrm{mg} / \mathrm{L}$ and $0.003-0.086 \mathrm{mg} / \mathrm{L}$, respectively (Trehy et al., 1995). The alkyl chain lengths usually range from $C_{10}$ to $C_{14}$ in the United States, and $C_{10}$ to $C_{13}$ in Europe (Huang et al., 2000). As it was reported that higher concentration of LAS does not respond to biological treatments, many investigators have tried degrading LAS using chemical processes. Table 2.3 shows some of the works carried on chemical treatment of LAS.

The intermediates produced by wet air oxidation of LAS were known as volatile fatty acids (VFA), sulfophenyl(di) aldehyde (SP(d)A), and sulfophenyl(di) carboxylate $(\mathrm{SP}(\mathrm{d}) \mathrm{C})$. It has also been reported that $\mathrm{SP}(\mathrm{d}) \mathrm{Cs}$ are refractory to biodegradation (Patterson et al., 2002). Photocatalytic degradation of $\mathrm{LAS}$ with $\mathrm{TiO}_{2}$ was documented to produce sodiumbenzene sulfonate (BS) and sodium dodecylsulfate (DS) (Venhuis and Mehrvar, 2004).

\subsection{Environmental Concerns and Biodegradability of LAS}

LAS is the major anthropogenic source of organic compounds in primary sludge in municipal wastewater treatment plants, as it can be adsorbed onto suspended solids 
ranging from 30 to $70 \%$ (Berna et al., 1989) and, hence, escaping aerobic treatment. It has also been identified in surface water supplies in the concentration of lower than $\mu \mathrm{g} / \mathrm{L}$ (Tabor and Barber, 1996) and in drinking water in the range of $0.001-0.008 \mathrm{mg} / \mathrm{L}$ in different countries (WHO, 1996). It is also able to enhance the solubility of compounds in water, which are otherwise insoluble in other matrices; hence, it can reduce the resistance to mass transfer (Vazquez et al., 2000).

High mobility of LAS due to its high water solubility and its polarity makes it to be a hazardous contaminant in ground and surface water supplies (Reemtsma, 1996). LAS can be degraded in activated sludge system by consortia of aerobic microorganisms (Van Ginkel, 1996) up to $99.5 \%$ and its intermediates up to $99.1 \%$ (Trehy et al., 1996). On the other hand, it has been reported that the intermediates produced by biological treatments are 10-100 times less toxic than the parent compounds (WHO, 1996).

The solid residence time (SRT) of mixed culture is very important to preserve adequate surfactants, degrading microorganism in the wastewater treatment plant (Van Ginkel, 1996). Moreover, it was found that in the activated sludge procedure the effluent concentration of LAS was a function of influent concentration when the hydraulic residence time (HRT) was less that $10 \mathrm{~h}$ (Kaiser et al., 1997). Some residue of LAS and its intermediates can enter the receiving water by the effluent if the HRT is not chosen properly. Furthermore, some of the countries discharge their effluents either directly or indirectly due to the malfunctioning of the treatment facilities into rivers. Another way that LAS can enter the environment is by using the sludge resulted from wastewater treatment plants on the agricultural lands. As a result, the aquatic and terrestrial organisms are exposed to surfactants.

LAS has shown toxic effects on the Nitrosomonas and Nitrosopria strains (Brandt et al., 2001). The inhibitory effect was observed to be more on growth rate and viability than that on metabolic activity. LAS has shown inhibitory effect on anaerobic biological treatment (Morales et al., 2001, and Gavala and Ahring, 2002). It is also reported that methanogenic and acidogenic microbiotes are sensitive to LAS although after a period of adaptation, there could be a decrease of the inhibitory effect of LAS on 
Table 2.3: Chemical degradation of LAS by different advanced oxidation processes

\begin{tabular}{|c|c|c|c|}
\hline $\begin{array}{c}\text { Initial } \\
\text { Concentration }\end{array}$ & Oxidation scheme & Grade & Reference \\
\hline 0.25 to $2 \mathrm{mg} / \mathrm{L}$ & Fenton's reaction & $\begin{array}{c}90 \mathrm{mg} \mathrm{FeSO}_{4} / \mathrm{L}, 60 \mathrm{mg} \\
\mathrm{H}_{2} \mathrm{O}_{2} / \mathrm{L} \\
95 \% \text { degraded. }\end{array}$ & Lin et al., 1999 \\
\hline $1000 \mathrm{mg} / \mathrm{L}$ & wet air oxidation & $\begin{array}{l}\text { LAS was readily oxidized } \\
\text { under mild condition }\end{array}$ & Mantzavinos et al., 2000 \\
\hline $1 \mathrm{~g} / \mathrm{L}$ & Fenton's reaction & $\begin{array}{c}30 \mathrm{mgFeSO}_{4} / \mathrm{L} \\
60 \mathrm{mgH}_{2} \mathrm{O}_{2} / \mathrm{L} \\
38 \% \text { degraded }\end{array}$ & Cuzzola et al., 2001 \\
\hline $1600 \mathrm{mg} / \mathrm{dm}^{3}$ & wet air oxidation & $\begin{array}{c}\text { Increased the } \\
\text { biodegradability under } \\
\text { higher temperature }\end{array}$ & Patterson et al., 2002 \\
\hline $\begin{array}{l}2.8 \times 10^{-5} \\
\mathrm{~mol} / \mathrm{dm}^{3}\end{array}$ & $\mathrm{TiO}_{2}+\mathrm{UV}-\mathrm{C}$ & $\begin{array}{c}\text { Conversion rate can be up to } \\
93 \% \text { in } 120 \mathrm{~min}\end{array}$ & Saien et al., 2003 \\
\hline $125 \mathrm{mg} / \mathrm{L}$ & $\mathrm{TiO}_{2}+\mathrm{UV}_{365}$ & $\begin{array}{l}\text { Optimum concentration of } \\
\mathrm{TiO}_{2}=3 \mathrm{~g} / \mathrm{L} \text { gave } \mathrm{r}_{0}=1.7 \\
\text { mg LAS } / \mathrm{L} . \mathrm{min}\end{array}$ & Venhuis and Mehrvar, 2004 \\
\hline $138 \mathrm{mg} / \mathrm{L}$ & UV-254 nm & $70 \%$ removal in $300 \mathrm{~min}$ & Venhuis and Mehrvar, 2004 \\
\hline
\end{tabular}


them (Morales et al., 2001). As the primary sludge stabilizes anaerobically and LAS is not biodegradable by anaerobic treatment, this sludge has environmental effect due to LAS potential for acute toxicity (Hofer et al., 1995, and Lewis, 1991).

It has been reported that LAS in the concentrations of $1-3-10 \mathrm{mg} / \mathrm{L}$ is biodegradable under aerobic activated sludge treatment (Rittmann et al., 2001), and its degradation follows Monod's equation over the ranges of $0.1-20 \mathrm{mg} / \mathrm{L}$ (Rittmann et al., 2001). Moreover, it has been reported that the fate of LAS can follow first order kinetics for the similar ranges of concentrations (Huang et al., 2000, and Zhang et al., 1999). Also, the effect of biodegradation kinetics should be separated from the sorption kinetics (Rittmann et al., 2001). However, the growth rate of mixed culture of microorganisms can be inhibited at the concentration of $95 \mathrm{mg} / \mathrm{L}$ (WHO, 1996). The minimum concentration of LAS which makes it toxic is not known (Patterson et al., 2002). Acute toxicity $\mathrm{LC}_{50}$ for different species differs from one to another, as saline water species are more sensitive to LAS than freshwater (WHO, 1996).

LAS biodegradation follows two regimes: 1) primary degradation, which oxidizes alkyl chain resulting sulfophenyl(di)carboxylates, and 2) ultimate biodegradation, which cleavage the phenyl ring and removing sulfonate group. Finally it is converted into $\mathrm{CO}_{2}$, $\mathrm{H}_{2} \mathrm{O}$, inorganic salts, and biomass. The bacteria that are capable of breaking the ring are not common (Patterson et al., 2002).

It was also investigated that ultimate biodegradation of LAS cannot be achieved at any concentration. Although the inhibitory effect of LAS increases as the concentration of LAS increases and inhibits primary degradation. It suggests that LAS is recalcitrant at very high concentration $\left(3000 \mathrm{mg} / \mathrm{dm}^{3}\right.$ ) (Patterson et al., 2002). This can be due to the chemical toxicity and the destruction of cell membrane caused by high concentration of LAS (Patterson et al., 2002). It has been reported that ultimate biodegradation is possible under suitable condition and limiting the concentration of LAS to that found in environment (WHO, 1996). 
Hydrophobic and hydrophilic parts of LAS can react with polar and apolar structures such as proteins and peptides. This binding can modify the structure and charge of proteins and peptides; furthermore, it can modify their biological function (Cserhati et al., 2002). Therefore, LAS can accumulate in living organisms, as it can inhibit in the hepatic liposomes of rat and inhibit the activity of some of the enzymes (Cserhati et al., 2002).

LAS can also damage human skin and irritate eyes (WHO, 1996). It has been established that the longer the alkylbenzene chain is, the more severe the skin irritancy potential can be (Cserhati et al., 2002). LAS and its intermediates resulting from biological treatments are not estrogenic (Navas et al., 1999).

\subsection{Concluding Remarks}

For the removal of recalcitrant organics, biological processes (which are economically beneficial) cannot be chosen, but a variety of non-biological processes exist which can be divided into oxidative and reductive technologies. Among all of them, photochemical degradation processes, or advanced oxidation processes (AOPs), have become increasingly popular in recent years as alternative or complementary treatment. The primary use of AOPs is to destroy organic pollutants in water by oxidation. However, depending on the targeted effluent quality, extended treatment duration may impose unaffordable high operating costs due to high energy and chemical oxidation requirements of AOPs. A recently proposed technique to cope with the environmental regulations and also environmentally safer and economically more attractive strategy is biodegradability enhancement of raw and biological pretreated industrial effluents by applying chemical oxidative pretreatment, in which two or three consecutive chemical and biochemical processes steps are involved. Moreover, as the complete destruction of wastewater pollutants can be hardly achieved by a single treatment method, combination of biological and chemical treatment is often the way to optimize the overall process. Depending on water quality, final requirement and economical aspects, some processes are better suited than others for each case. The strategy of coupling chemical and 
biological reactors is not necessarily a unique solution. The practical applications of these integrated processes require a detailed study on kinetic modeling and economic aspects. Chemical, biological, and kinetic studies should be made to ensure that the pre-treatment or the post-treatment increase the biocompatibility of wastewater. A balance between added cost of AOPs and desired quality of treated wastewater is highly recommended to make sure that the AOP pre-treatment induces a beneficial effect on the bio-compatibility of the treated wastewater (or the biological pre-treatment has beneficial effect on the following chemical step).

$\therefore$, been documented that complete mineralization of LA.; it chievable under biological degradation, especially when the concentration of LAS is high (Zhang et al, 1998). Moreover, LAS can be toxic to microorganisms. Therefore, advanced oxidation processes can be a good choice to chemically degrade LAS. However, as AOP is a relatively expensive method, combination of AOP and biological technique could be a better option. Furthermore, as ultimate biodegradation of LAS involves breakage of phenyl ring, the bacteria that are capable of breaking the ring are not common. Therefore, adaptation of bacteria to LAS can increase the rate of biodegradation. 


\section{CHAPTER 3}

\section{EXPERIMENTAL WORK}

\section{MATERIALS, METHODS, AND EQUIPMENT}

\subsection{Materials}

The following materials were used in chemical and biological experiments.

\subsubsection{Linear Alkylbenzene Sulfonate (LAS)}

LAS is the sodium salt of dodecylbenzenesulfonic acid, a mixture of phenylsubstituted alkyl chain (Figure 3.1). Sodium salt of dodecylbenzenesulfonic acid was purchased from Aldrich Company to study the degradation characteristics of LAS. The alkyl chain contains 12 carbons with the molecular weight of 348.48 . The scanning of UV-spectrophotometer showed that the maximum absorbance for this compound is at $268 \mathrm{~nm}$ (Figure 3.2).

\subsubsection{Activated Sludge}

Activated sludge was collected from North Toronto sewage treatment plant, located in the Don Valley. The concentration of sludge (dry weight) was $4.8 \mathrm{~g} / \mathrm{L}$ and the amount of LAS initially present in the sludge of treatment plant was $4 \mathrm{mg} / \mathrm{L}$.

\subsubsection{Hydrogen Peroxide}

Hydrogen peroxide used in all of the experiments was purchased from Aldrich. It was $50 \mathrm{wt} \%$ (remaining was water) with molecular weight of 34.04 , and density of 1.11 $\mathrm{g} / \mathrm{cm}^{3}$. It should be stored at $2-8^{\circ} \mathrm{C}$ to retain its quality. 


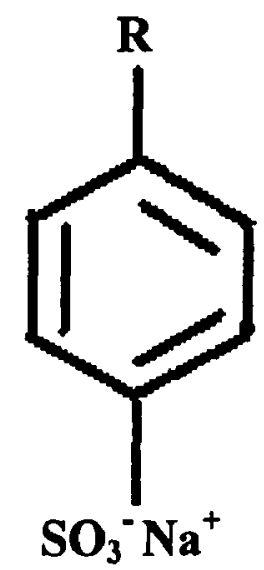

Figure 3.1: Molecular structure of LAS, R represents the alkyl chain $\mathrm{R}=\left(\mathrm{CH}_{2}\right)_{11} \mathrm{CH}_{3}$.

Molecular weight $=348.48$. 


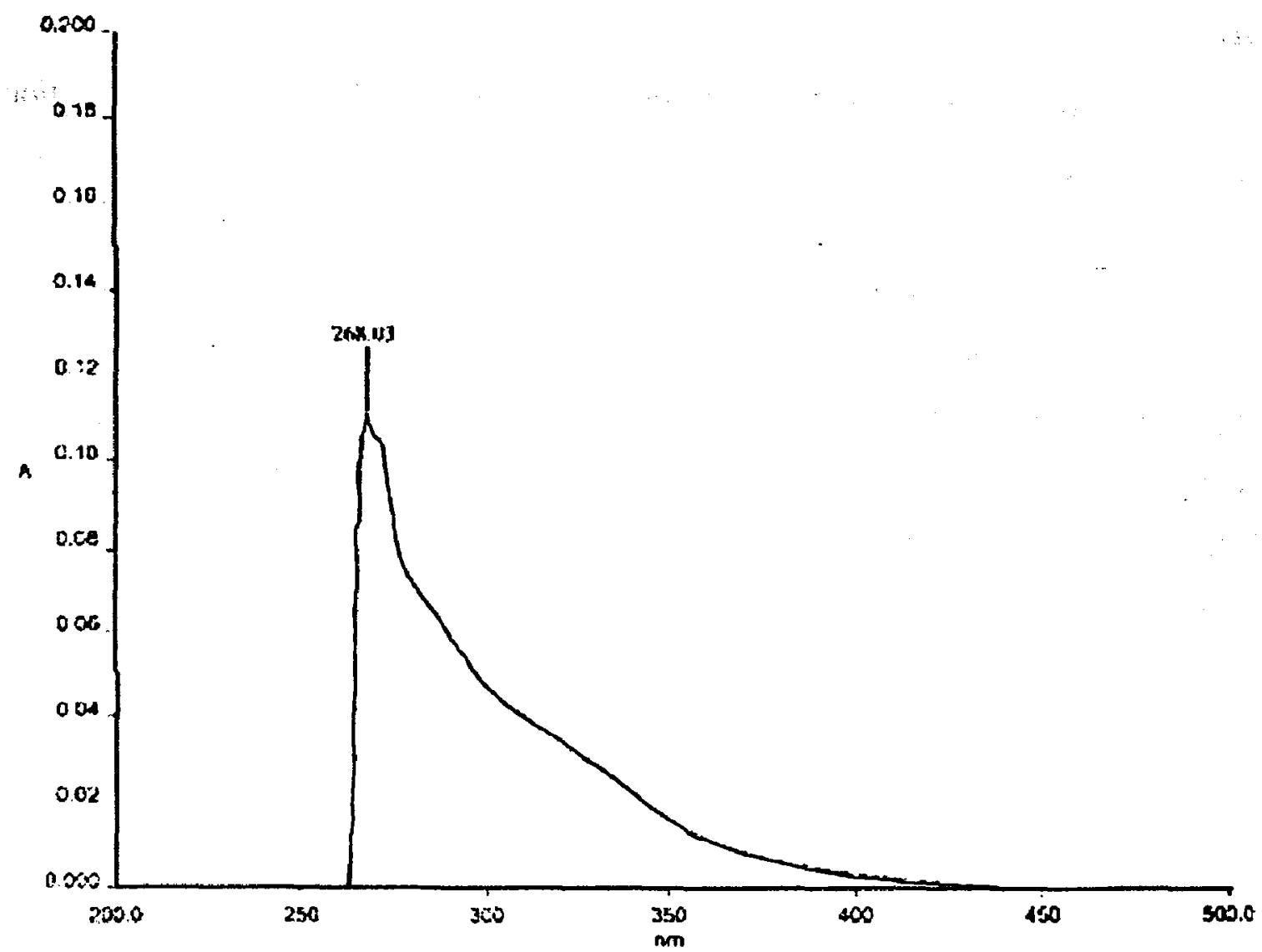

Figure 3.2. The scanning of LAS with UV-spectrophotometer, the concentration of LAS was $100 \mathrm{mg} / \mathrm{L}$. 


\subsubsection{Catalase}

$\mathrm{H}_{2} \mathrm{O}_{2}$ concentration less than $200 \mathrm{mg} / \mathrm{L}$ may be removed effectively by addition of a catalase $(2.5$ units $/ \mathrm{mL}$ ) by keeping the solution for 2 hours without stirring (Ito et al., 1998). Each molecule of catalase is a tetramer of four polypeptide chains. Each chain is composed of more than 500 amino acids. Located within this tetramer are four porphyrin heme groups that are very much like the familiar hemoglobins, cytochromes, chlorophylls and nitrogen-fixing enzymes in legumes. The heme group is responsible for catalase's enzymatic activity. The mechanism of removal is catalytic decomposition of $\mathrm{H}_{2} \mathrm{O}_{2}$ into oxygen and water. The chemistry of catalase catalysis has not been precisely solved yet. But the following has been proposed. The catalytic process is thought to occur in two stages (http://biology.kenyon.edu/BMB/Chime/catalase, 2004)

$$
\begin{aligned}
& \mathrm{H}_{2} \mathrm{O}_{2}+\mathrm{Fe}(\mathrm{III})-\mathrm{E} \rightarrow \mathrm{H}_{2} \mathrm{O}+\mathrm{O}=\mathrm{Fe}(\mathrm{IV})-\mathrm{E}(\mathrm{l}) \\
& \mathrm{H}_{2} \mathrm{O}_{2}+\mathrm{O}=\mathrm{Fe}(\mathrm{IV})-\mathrm{E} \rightarrow \mathrm{H}_{2} \mathrm{O}+\mathrm{Fe}(\mathrm{III})-\mathrm{E}(2)+\mathrm{O}_{2}
\end{aligned}
$$

where Fe-E represents the iron center of the heme attached to the rest of the enzyme (E) (Figure 3.3). Heme consists of a protoporphyrin ring and a central iron (Fe) atom. A protoporphyrin ring is made up of four pyrrole rings linked by methane bridges. Four methyl, two vinyls, and two propionate side chains are attached (http://crystal.uah.edu, 2000).

This enzyme is available in two forms: 1) bovine liver 2) Aspergillis niger. The amount of enzyme added depends on its activity and can be found on its label. However, the impact of the enzyme on the sample should be known. The catalase which was used in this experiment was bovine liver type, purchased from SIGMA Company. Molecular weight of catalase is 250,000 , and it is stable for 6-12 months when stored at $5^{\circ} \mathrm{C}$. It was mentioned on the package that one unit of this catalase has the ability of decomposing 1 $\mu \mathrm{mol}$ of $\mathrm{H}_{2} \mathrm{O}_{2}$ per minute at $\mathrm{pH}$ equal to 7.0 at $25{ }^{\circ} \mathrm{C}$. Each 2380 unit of this catalase is equivalent to $1 \mathrm{mg}$ of catalase. 


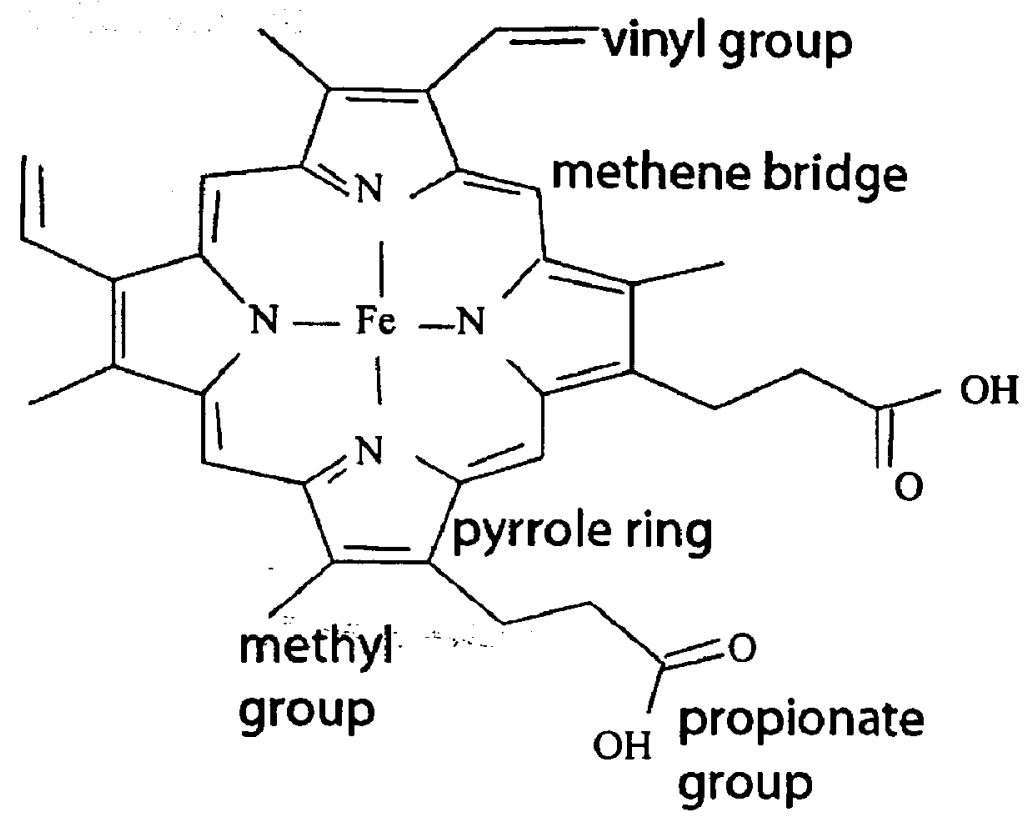

Figure 3.3. Molecular structure of Heme group attaching to the rest of the enzyme, representing the catalase enzyme. 


\subsubsection{Chemicals for Analysis of LAS}

Chloroform $\left(\mathrm{CHCl}_{3}, 99.98 \%\right)$ was purchased from EM Science (affiliated with Merck, Germany) and used as received. Methylene blue reagent was purchased from Aldrich. To make $100 \mathrm{mg}$ of methylene blue, it was dissolved in $100 \mathrm{~mL}$ of distilled water (stock solution). Thirty $\mathrm{mL}$ of the stock solution was transferred to $1000 \mathrm{~mL}$ flask and $500 \mathrm{~mL}$ of water, $41 \mathrm{~mL}$ of $6 \mathrm{~N} \mathrm{H}_{2} \mathrm{SO}_{4}$, and $50 \mathrm{~g} \mathrm{Na} \mathrm{H}_{2} \mathrm{PO}_{4} \cdot \mathrm{H}_{2} \mathrm{O}$ were added. The solution was diluted to $1000 \mathrm{~mL}$ by distilled water after dissolving thoroughly.

Wash solution was prepared by adding $41 \mathrm{~mL}$ of $6 \mathrm{~N} \mathrm{H}_{2} \mathrm{SO}_{4}$ to $500 \mathrm{~mL}$ of distilled water, and $50 \mathrm{~g}$ of $\mathrm{NaH}_{2} \mathrm{PO}_{4} \cdot \mathrm{H}_{2} \mathrm{O}$ was added to that solution. The solution was diluted to 1000 $\mathrm{mL}$ by distilled water after dissolving thoroughly.

Standard LAS solution was prepared by diluting the appropriate weight of LAS, with distilled water.

Sodium hydroxide $(\mathrm{NaOH})$ was $1 \mathrm{~N}$, and sulfuric acid $\left(\mathrm{H}_{2} \mathrm{SO}_{4}\right)$ was $1 \mathrm{~N}$ and $6 \mathrm{~N}$. Phenolphthalein indicator solution was purchased from Aldrich Company and used as received.

\subsubsection{Nutrients for Biological Measurements}

Reagents used for biological measurements are as follows (Standard Methods, 1998):

Nutrients: consist of phosphate buffer solution, magnesium sulfate solution, ferric chloride solution, and calcium chloride solution. These nutrients are essential for the growth of microorganisms.

Phosphate buffer solution: $8.5 \mathrm{~g} \mathrm{KH}_{2} \mathrm{PO}_{4}, 21.75 \mathrm{~g} \mathrm{~K}_{2} \mathrm{HPO}_{4}, 33.4 \mathrm{~g} \mathrm{NaHPO}_{4} \cdot 7 \mathrm{H}_{2} \mathrm{O}$, and $1.7 \mathrm{~g} \mathrm{NH}_{4} \mathrm{Cl}$ was dissolved in distilled water and diluted to $1000 \mathrm{~mL}$. The $\mathrm{pH}$ was 7.2 without adjustment. To keep the $\mathrm{pH}$ constant, buffer solution should be added to the diluted water.

Magnesium sulfate solution: $22.5 \mathrm{~g} \mathrm{MgSO}+7 \mathrm{H}_{2} \mathrm{O}$ were dissolved in distilled water and diluted to $1000 \mathrm{~mL}$.

Ferric chloride solution: $0.25 \mathrm{~g} \mathrm{FeCl} \cdot 6 \mathrm{H}_{2} \mathrm{O}$ were dissolved in distilled water and diluted to $1000 \mathrm{~mL}$. 
Calcium chloride solution: $27.5 \mathrm{~g} \mathrm{CaCl}_{2}$ were dissolved in distilled water and diluted to $1000 \mathrm{~mL}$.

\subsubsection{Standard Check Solution for Biological Measurements}

Standard check solution: was made of glucose-glutamic acid solution. Glucose and glutamic acid were first dried at $103^{\circ} \mathrm{C}$ in the oven for $1 \mathrm{~h} .150 \mathrm{mg}$ of glucose and $150 \mathrm{mg}$ of glutamic acid were dissolved in distilled water and diluted to $1000 \mathrm{~mL}$. This solution was prepared before each use.

\subsubsection{Seed Source}

Seed source: Seed might also be added to provide enough microbial population. Polyseed (interlab) was used as the seed source. It was a blend of wide range of bacteria (mixed culture) prepared to use in the $\mathrm{BOD}_{5}$ test.

\subsubsection{Reagents for Hydrogen Peroxide Analysis}

DMP (2,9-dimethyl-1,10-phenanthroline) reagent (99\%) was purchased from Sigma Co. One gram of it was dissolved in $100 \mathrm{~mL}$ of ethanol and stored in dark bottle at $4^{\circ} \mathrm{C}$. $0.01 \mathrm{M}$ of copper(II) sulphate solution was made by dissolving copper(II) sulphate into distilled water. Moreover, a phosphate buffer solution $(0.1 \mathrm{M})$ was prepared from $13.5 \mathrm{~g} \mathrm{~K}_{2} \mathrm{HPO}_{4}$ and $12 \mathrm{~g} \mathrm{NaH}_{2} \mathrm{PO}_{4}$. The $\mathrm{pH}$ of this solution should be adjusted to 7 by $\mathrm{H}_{2} \mathrm{SO}_{4}(1 \mathrm{~N})$ and $\mathrm{NaOH}(1 \mathrm{~N})$ (Kosaka et al., 1998).

\subsubsection{Check Kit for Free Chlorine}

Chlorine check kit consisted of N,N-diethyl-p -phenylenediamine (DPD) tablets (VWR) and a colorimetric kit. The detection range was between $0.2-2$ and $2-10 \mathrm{mg} / \mathrm{L}$ free chlorine. To perform the experiment the vial should be filled with water up to the marked point, which would be $2 \mathrm{~mL}$, and one tablet should be added to the water. After crushing the tablet and mixing it thoroughly, the color produced in the vial should be compared to the colors on the kit. Each color on the kit was corresponding to a certain concentration. 
By matching to the produced color in the vial to the appropriate color, the concentration of the free chlorine in the water was found in terms of $\mathrm{mg} / \mathrm{L}$ of free chlorine.

\subsection{Equipment and Experimental Methods}

This section has been divided into two parts, photolytic and biological processes. Experimental set-up, analytical techniques, and equipment required for each photolytic and biological treatment are described separately.

\section{PHOTOLYTIC PRGCESSES}

\subsubsection{Experimental Set-Up (Photoreactor)}

The experiments were performed in a $76.6 \mathrm{~L}$ cylindrical batch photoreactor, with the outside diameter of $32 \mathrm{~cm}$ and nominal length of $102 \mathrm{~cm}$ (Figure 3.4). Six immersed low pressure mercury UV lamps, with the maximum wavelength of $253.7 \mathrm{~nm}$ and $40 \mathrm{~W}$ each, were symmetrically placed inside the photoreactor. The photoreactor was equipped with 3 mixers, placed on the main axis of the cylindrical photoreactor. The speed of these mixers could be adjusted as desired. The total volume of the feed tank was $210 \mathrm{~L}$, and the minimum volume of water in the tank for operation should be $94 \mathrm{~L}$. A centrifugal pump recirculated the solution into the reactor. The flow rate of the feed was adjustable in gallons per minute (GPM) or liters per minute (LPM). The whole system was equipped with a water bath (Neslab, RTE series) to keep the temperature constant at $20 \pm 0.01^{\circ} \mathrm{C}$ during the experiment. The volume of water in the water bath was kept between 10-12 L. Prior to start the each experiment, $10 \mathrm{~g}$ of LAS was added to the $100 \mathrm{~L}$ water inside the feed tank. The whole system was turned on, including the water bath and the pump for the period of maximum $1 \mathrm{~h}$, the UV lamps were all off with the feed tank lid closed. After that period which was called stabilization period, the $6 \mathrm{UV}$ lamps were turned on simultaneously. Furthermore, the temperature of the reactor was kept constant at $20^{\circ} \mathrm{C}$ using the water bath during all the experiment, therefore, the effect of increasing the temperature due to the UV lamps have been eliminated. 


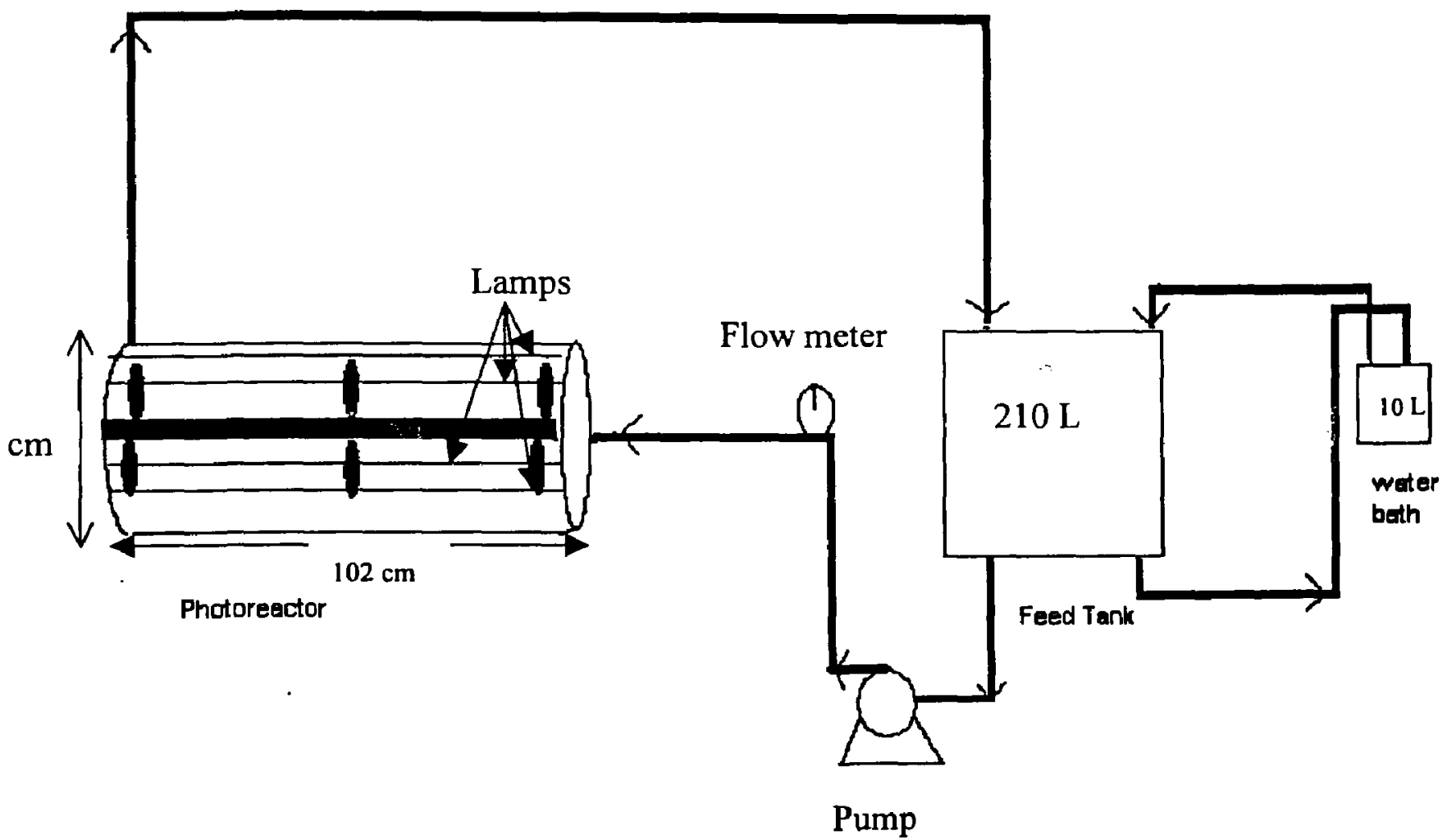

Figure 3.4. Schematic diagram of the cylindrical photolytic reactor. 
Three samples were taken every hour from the effluent of the reactor (inlet to the feed tank). and analyzed immediately. The initial concentration of LAS was $100 \mathrm{mg} / \mathrm{L}$. After taking the last sample, the pump was shut down and the lamps were turned off. The water bath was also turned off. The reactor was drained into the feed tank by opening its side valve. After collecting all of the solution inside the feed tank, the tank was drained by pumping the water out. The whole system was cleaned and made ready for the next run.

\subsection{2 pH Measurement}

$\mathrm{pH}$ measurements and its control are important in water treatment systems. As in biological treatment, the life of microorganisms highly depends on a certain range of $\mathrm{pH}$, in chemical treatment, the control of $\mathrm{pH}$ is also crucial as changing $\mathrm{pH}$ can have a significant effect on the reaction. Moreover, in advance oxidation processes measurements of $\mathrm{pH}$ can show that the reaction is moving toward production of acid, which is the expected path.

$\mathrm{pH}$ measurements are mainly done by potentiometric measurement using a glass indicator electrode and a reference electrode. The $\mathrm{pH}$ meter used in these experiments was model $230 \mathrm{~A}^{+}$from Thermo Orion, in which the indicator and reference electrodes were combined into one. The buffers of $\mathrm{pH}=4$ and $\mathrm{pH}=7$ were used to calibrate the meter before $\mathrm{pH}$ was measured. Those two buffers were chosen in the expected sample range. The calibration was done each day by determining the slope of the electrode. Also calibration can determine if the electrode was working properly.

\subsubsection{UV Spectrophotometer}

A UV spectrophotometer was used for quantification of color in terms of absorbance. The spectrophotometer used was Ultrospec 1100 pro UV/Vis Spectrophotometer (Biochrom Ltd.), with the ability to measure the absorbance, percent Transmission, and concentration values. It can measure absorbance of samples, based on the amount of light that has passed through a sample relative to a blank. While percent transmission mode measures the amount of light that has passed through a sample relative to a blank, it displays the result as a percentage. Concentration mode is used 
when a conversion factor is known, and is required to convert the absorbance measurement for a sample at a specific wavelength into a concentration. The wavelength range was within $200-900 \mathrm{~nm}$ with the accuracy of $\pm 2 \mathrm{~nm}$.

The light sources are tungsten halogen and deuterium arc (Ultrospec 1100 pro). The instrument has a one cell compartment. The detector was from single solid state silicon photodiode. The cell used for the experiments was a standard rectangular quartz cell (optical glass). The cell's volume was $3 \mathrm{~mL}$, and has a polytetrafluoroethylene (PTFE) cover.

\subsubsection{Preparation of the Initial Solution for Photolytic Experiments}

Ten $\mathrm{g}$ of the dodecylbenzenesulfonic acid (flaked sodium salt solid), was added to $100 \mathrm{~L}$ of tap water inside the feed tank. Therefore, the concentration of LAS inside the system would be $100 \mathrm{mg} / \mathrm{L}$. The solution was circulated for one hour with lights off in order to make the solution homogeneous throughout the system.

\subsubsection{Measurements of Linear Alkylbenzene Sulfonate}

The detection method of LAS was based on the transfer of methylene blue active substance (MBAS), which is a cationic dye, from an aqueous solution into an immiscible phase containing anionic surfactant. This transfer is possible by ion pair formation of anionic surfactant and methylene blue. Excess methylene blue was extracted into chloroform and the blue color in the chloroform would be read at $652 \mathrm{~nm}$ by UV Spectrophotometer (Standard Methods, 1998). The interference result from all other methylene blue active substances present in the solution. Moreover, cationic surfactants can have a negative effect on the determination as they can compete with methylene blue in the formation of the pairs. Organic sulfonates, sulfates, carboxylates, and phenols can also have positive interference, although their recovery is almost complete by aqueous backwash of the extracted color in chloroform, therefore, the concentration of LAS has been reported here as $\mathrm{mg} / \mathrm{L}$ MBAS due to the positive error that was explained before. The reagents used in this experiment were those explained in Section 3.1.5. 
The samples taken periodically from the effluent of the reactor (inlet to the feed tank) were diluted, so that the measured concentration would be below $2 \mathrm{mg} / \mathrm{L}$. Two $\mathrm{mL}$ of samples were diluted to $100 \mathrm{~mL}$. Two $\mathrm{mL}$ of the diluted samples were taken; phenolphthalein indicator solution was added drop wise to each sample. The samples were make alkaline by drop-wise addition of $\mathrm{NaOH} 1 \mathrm{~N}$, and the pink color was removed by adding drop wise of $\mathrm{H}_{2} \mathrm{SO}_{4} 1 \mathrm{~N}$. One $\mathrm{mL}$ of chloroform and $2.5 \mathrm{~mL}$ of methylene blue were added to each sample and shaken vigorously for $30 \mathrm{~s}$. The aqueous phase was taken to another tube and the extraction procedure was repeated for 3 times. All of the $\mathrm{CHCl}_{3}$ extracts were combined and $5 \mathrm{~mL}$ of wash solution were added to them and shaken vigorously for $30 \mathrm{~S}$. The wash solution was extracted twice by $\mathrm{CHCl}_{3}, 1 \mathrm{~mL}$ each time, and the extracts were diluted with $\mathrm{CHCl}_{3}$ to $10 \mathrm{~mL}$. The absorbance at $652 \mathrm{~nm}$ were determined against a blank of $\mathrm{CHCl}_{3}$ using the spectrophotometer (Section 3.2.3). Standard curve was prepared by determining the absorbance of known concentrations of standard solutions and the absorbance of each sample was converted into concentration using this curve and dilution factor. Figure 3.5 illustrates the calibration curve for LAS by the mentioned method.

\subsubsection{Measurement of Chemical Oxygen Demand (COD)}

COD was used to measure the amount of oxygen require to oxidize the organics in a solution by a powerful chemical oxidant. This oxidation is usually done by potassium dichromate in acidic solution.

The drawbacks of this method are as follows (Eckenfelder, 2000):

1. COD cannot oxidize aromatics such as benzene and volatile straight-chain aliphatic compounds; therefore, it is not measured in the COD tests. Therefore, it is lower than theoretical oxygen demand (ThOD).

2. Some reduced substances, such as sulfides, sulfites, and ferrous iron, would also be oxidized and measured as COD. 
COD can be determined by different methods, however, as the predicted COD for the samples was above $50 \mathrm{mg} / \mathrm{L}$ and there was not any suspended solid present in the sample, the closed refluxed method was chosen as it is more economical over this range of concentration (Standard Method, 1998). This method is based on the oxidation of organics by a mixture of $\mathrm{K}_{2} \mathrm{Cr}_{2} \mathrm{O}_{7}$ and sulfuric acid. Potassium dichromate is a strong oxidizing agent under acidic conditions. (Acidity is usually achieved by the addition of sulfuric acid.) The reaction of potassium dichromate with organic compounds is given by:

$\mathrm{C}_{\mathrm{n}} \mathrm{H}_{\mathrm{a}} \mathrm{O}_{\mathrm{b}} \mathrm{N}_{\mathrm{c}}+\mathrm{dCr}_{2} \mathrm{O}_{7}^{2-}+(8 \mathrm{~d}+\mathrm{c}) \mathrm{H}^{+} \rightarrow \mathrm{nCO}_{2}+(\mathrm{a}+8 \mathrm{~d}-3 \mathrm{c}) / 2 \mathrm{H}_{2} \mathrm{O}+\mathrm{cNH}_{4}{ }^{+}+2 \mathrm{dCr}^{3+}$

where $d=2 n / 3+a / 6-b / 3-c / 2$. Most commonly, a $0.25 \mathrm{~N}$ solution of potassium dichromate is used for COD determination, although for samples with COD below 50 $\mathrm{mg} / \mathrm{L}$, a lower concentration of potassium dichromate is preferred. In the process of oxidizing the organic substances found in the water sample, potassium dichromate is reduced, forming $\mathrm{Cr}^{3+}$. The amount of $\mathrm{Cr}^{3+}$ is determined after oxidization is complete, and is used as an indirect measure of the organic contents of the water sample.

In the colorimetric method (closed reflux), oxygen consumption is measured against standards at $600 \mathrm{~nm}$ with spectrophotometer. The reagents were prepared in a vials purchased from Bioscience, Inc., in the range of $20-900 \mathrm{mg} / \mathrm{L}$. Each vial contained sulfuric acid, potassium dichromate, silver sulfate (catalyst), mercuric sulfate (reduce the effect of halides), and sulfamic acid. Standard potassium hydrogen phthalate (KHP) was crushed and then dried to constant weight at $120^{\circ} \mathrm{C} .425 \mathrm{mg}$ of KHP was dissolved in distilled water and diluted to $1000 \mathrm{mg} / \mathrm{L}$. This solution had a theoretical COD of 500 $\mathrm{mg} / \mathrm{L} \mathrm{O} \mathrm{O}_{2}$. Different concentrations of this solution were prepared as reference to prepare calibration curve.

The COD reactor (Bioscience, Inc.) should be preheated to $150 \pm 2^{\circ} \mathrm{C}$ prior to preparing the vials. The vials with the volume of approximately $10 \mathrm{~mL}$ were uncapped carefully and $2.5 \mathrm{ml}$ of sample solution was added to the vial from the side of the vial 


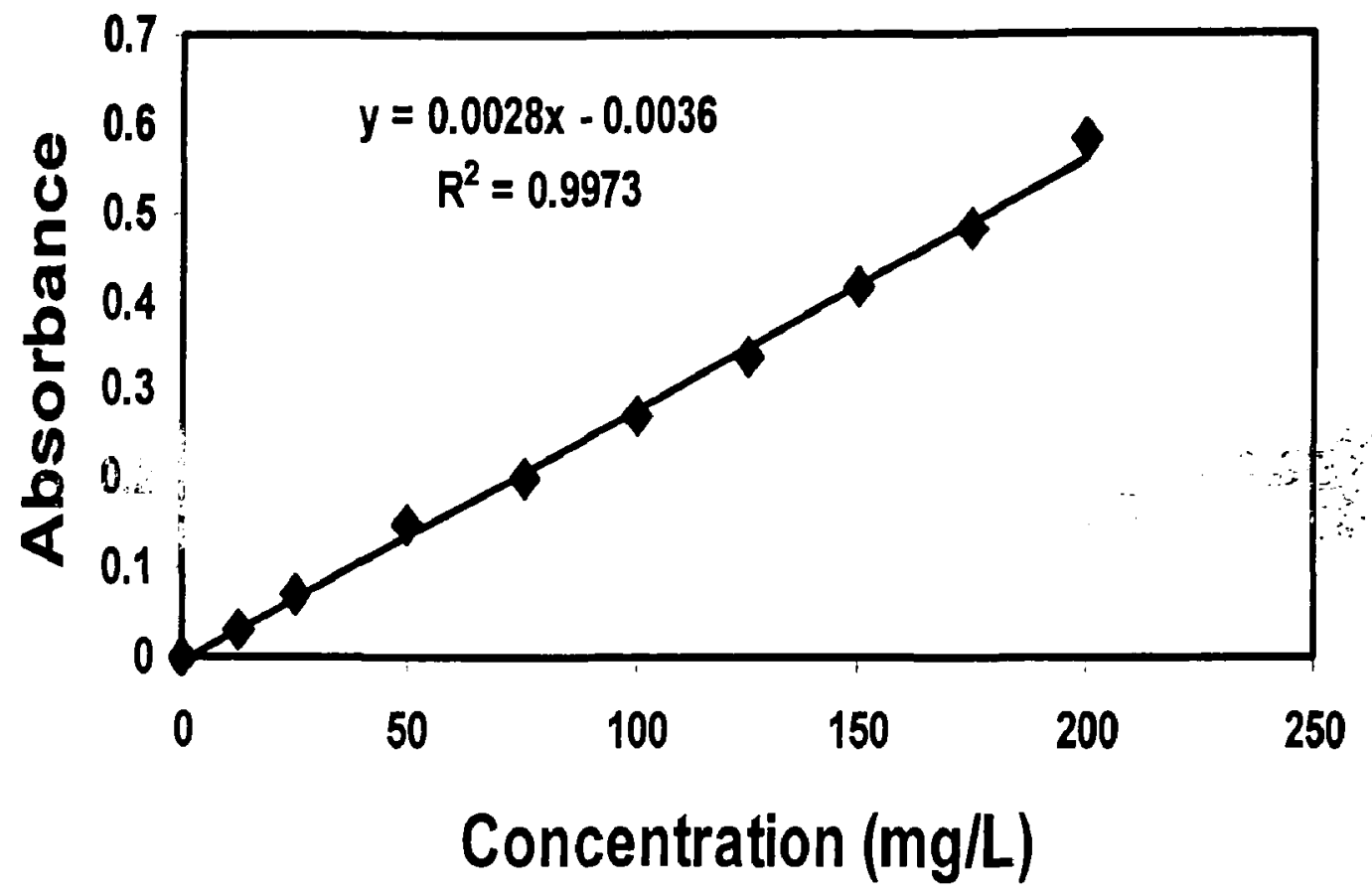

Figure 3.5. The calibration curve for LAS using MBAS method.

Absorbance, or optical density, is a measure of the amount of light absorbed by a solution. Absorbance is equal to the logarithm of the ratio of incident light to transmitted light. 
with extreme caution. The sample produced a layer on top of the reagents, therefore, the vials were recapped and inverted several times to mix thoroughly. The vial was then ready to be placed in the reactor at $150^{\circ} \mathrm{C}$ for 2 hours for complete reaction. After 2 hours, the vials were placed in a rack in room temperature to cool off to the room temperature. The absorbance at $600 \mathrm{~nm}$ was measured against a blank (distilled water) by spectrophotometer. The standard carve was prepared by adding an appropriate concentration of potassium hydrogen phthalate (KHP) to each vial. The same procedures were followed to prepare the standards and the blank. Figure 3.6 provides a calibration cure for the determination of COD using the above mentioned procedures.

\subsubsection{Theoretical Oxygen Demand (ThOD)}

Theoretical oxygen demand is the amount of oxygen required for full oxidation of organics. It can be calculated by the stoichiometry of oxidation.

\subsubsection{Initial Rate}

The initial rate was defined as slope of the concentration versus time at time equal to 0 .

\subsubsection{Free Chlorine Experiment}

It has been reported that free chlorine could react as an oxidant under UV light, and hence, increase the rate of reaction (Zhou and Smith, 2001). Furthermore, the presence of free chlorine could interfere with the determination of a specific compound. For the BOD test, elimination of free chlorine is necessary. Also for determination of $\mathrm{H}_{2} \mathrm{O}_{2}$, in some methods, free chlorine works as interference. To eliminate the free chlorine present in tap water, chlorine checkit consisted of DPD (,$N$-diethyl-p-phenylenediamine) tablets, were used for the following reasons:

1. To determine the initial concentration of free chlorine in the tap water, that was used to prepare the solution.

2. To determine the effect of elimination of free chlorine. 


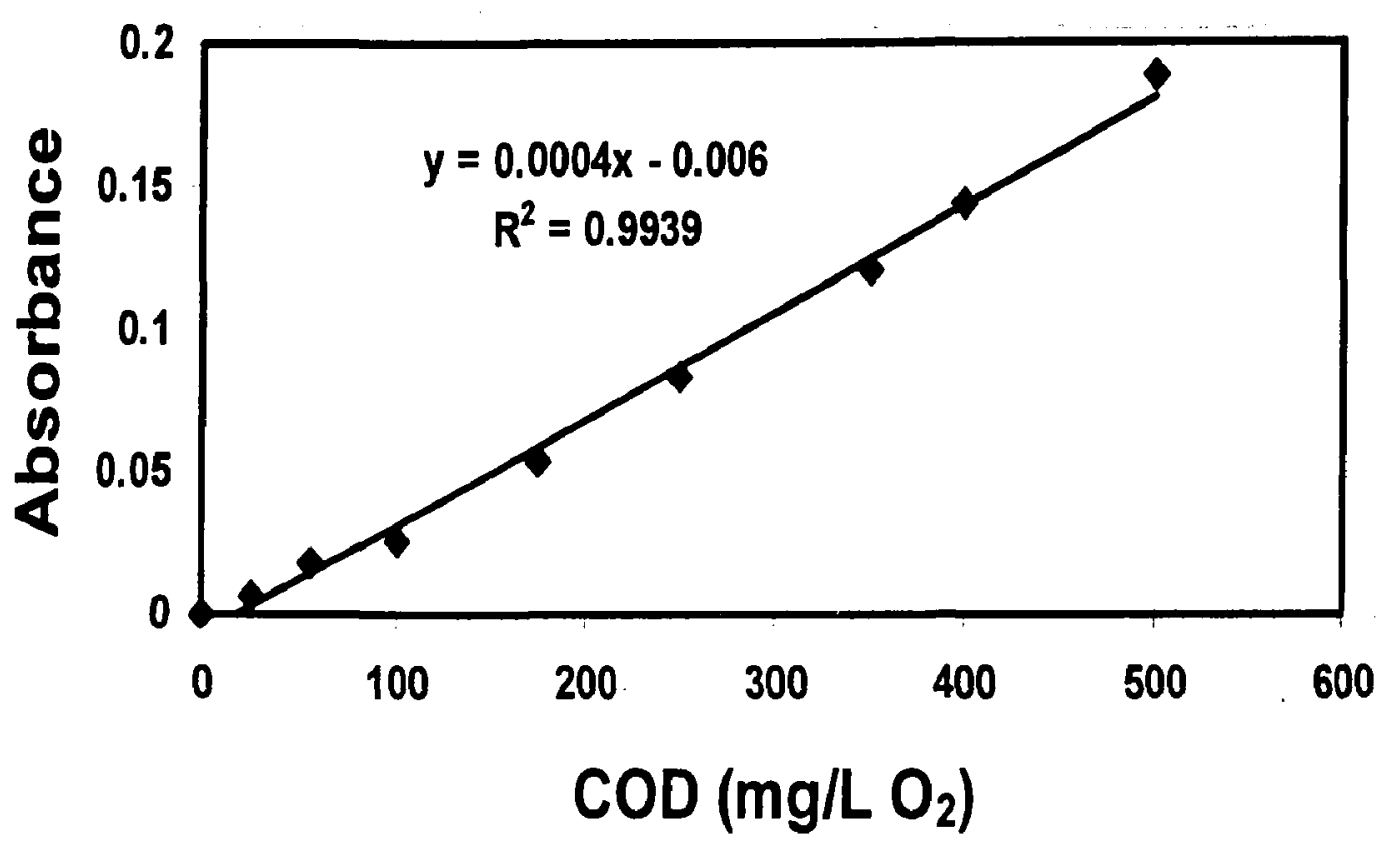

Figure 3.6. Calibration curve for determination of $\mathrm{COD}$, based on the closed refluxed method. Absorbance, or optical density, is a measure of the amount of light absorbed by a solution. Absorbance is equal to the logarithm of the ratio of incident light to transmitted light. 
The DPD method is based on the reaction of the free chlorine with DPD indicator, which produces a red color instantly. Therefore, it was necessary to remove the free chlorine presence in the tap water before adding LAS to eliminate any increase in the degradation of LAS due to free chlorine. The concentration of free chlorine in the tap water during different runs was examined and it was observed that it varies between 0-1.5 $\mathrm{mg} / \mathrm{L}$. Therefore, prior the each run, the feed tank was filled with water and let the free chlorine evaporate during the night by keeping the feed tank lid open. It was observed that this range of concentration of free chlorine could be eliminated by this method successfully. The experiments were conducted at least three times and the error bars which are the standard divisions of the results at each time were calculated.

\subsubsection{Dark Reaction Experiment}

To quantify the loss of LAS through adsorption, dark reaction experiments were conducted. The changes in the initial concentration of LAS were monitored after $1 \mathrm{~h}$. of stabilization period. For the period of $6 \mathrm{~h}$, the UV lamps were all off with the feed tank lid closed. Three samples were taken every hour from the effluent of the reactor (inlet to the feed tank). In order to minimize the environmental effects on the degradation of LAS, the samples were analyzed immediately.

\subsubsection{Photoreaction of LAS by UV-254}

In this experiment, all conditions were kept the same as to those of the dark reaction except that the $6 \mathrm{UV}$ lamps were turned on simultaneously after the stabilization period. Furthermore, the temperature of the reactor was kept constant at $20^{\circ} \mathrm{C}$ using the water bath during all the experiment, therefore, the effect of increasing the temperature due to the UV lamps have been eliminated. Three samples were taken every hour and analyzed immediately. The initial concentration of LAS was $100 \mathrm{mg} / \mathrm{L}$.

\subsubsection{Mixing Speed Experiment}

In order to determine the effect of mixing speed on the photolytic degradation rate of LAS, different experiments were conducted at different mixing speeds, with constant flow rates. There are different numbers on the mixer ranging from $0-10$, and each number 
is associated with different speed. Table 4.1 shows the mixing speed associated with each number. The rotational speed of each number was measured by Tachometer (DT-105 A, Electromatic Equipment Co., Inc.).

\section{BIOLOGICAL PROCESSES}

\subsubsection{Experimental Set-Up (Sequential Batch Reactor)}

Sequential batch reactor (SBR) is a suspended growth, mixed- culture reactor. However, it can be categorized as activated sludge treatment (Figure 3.7). Common activated sludge systems are spac: oriented, however, SBR is time oriented. It is a periodic process which consist of tanks working on a fill and draw basis. The cycles in each tank are divided into the following periods:

- Fill,

- react,

- settle,

- draw, and idle.

During the fill period, the wastewater is added to the tank which contains biomass. Biomass is expressed in term of volatile mixed liquor suspended solids which exist in the tank from the previous cycles. Fill period could be static fill (no mixing and no aeration), mixed fill (mixing and no aeration), and aerated fill (mixing and aeration). Type of filling period depends on the characteristic of wastewater. However the wastewater should be completely mixed in the system before the react period. In the react period, the reactions which have started in the fill period are completed. Aeration is an essential operation in this period. Also the system should have sufficient mixing to increase mass transfer. The react period usually takes $35 \%$ of the whole cycle's time. The next period is settlement. The entire tank works as clarifier and separates sludge from the liquor. After the settlement period, effluent is ready to be withdrawn. During this period there should not be any agitation in the system. After drawing, the tank is ready for the new influent. It can be left idle between draw and fill period. This period is required if wasting sludge is necessary. 
The reactor used in the experiments had a $7 \mathrm{~L}$ volume and the aeration was done by air diffuser as shown in Figure 3.7.

\subsubsection{Incubator}

The incubator was used to provide a constant temperature during the period of biological reaction. Temperature is a crucial factor on microorganism. It was set at $20^{\circ} \mathrm{C}$ as it was the optimum temperature for the BOD tests. Moreover, as it could be set to have horizontal plane rotary motion in a 1" circular orbit simultaneously, it was used in the shake flask experiments.

The incubator used was $\mathrm{C}-25 \mathrm{KC}$ classic refrigerated incubator shaker (New Brunswick Scientific Co., Inc.). The speed of this model could be set between 40-400 $\mathrm{rpm}$ (with the accuracy of $\pm 2 \mathrm{rpm}$ ) and the accuracy for the temperature was $\pm 0.25^{\circ} \mathrm{C}$.

\subsubsection{Dissolved Oxygen Meter}

The oxygen is also an important factor on the life and growth of aerobic microorganism. Therefore, it has to be controlled to avoid the death of aerobic microorganism. Mainly the saturated concentration of oxygen in the aerated water at $20^{\circ} \mathrm{C}$ can be between 8-10. As a result, the decrease of oxygen in that water could suggest that it is being used by the microorganisms (provided that there is no other way for the water to loss its dissolved oxygen content).

The dissolved oxygen (DO) was measured by YSI 58 dissolved oxygen meter. It has a probe consists of an electrode (compacting cathode and anode in a one bar) and an electrolyte $(\mathrm{KCl})$. They are separated from the outer liquid by a membrane. The anode and cathode are made of silver and gold, respectively. The reduction of oxygen in cathode is proportional to concentration of dissolved oxygen. If the temperature changes, the dissolved oxygen will vary due to the change in the solubility of oxygen at different temperature. This meter should be calibrated prior to each use. 
Table 3.1 The corresponding speed in rpm of the mixer installed on the photo-reactor

\begin{tabular}{|cc|}
\hline Number & Speed (rpm) \\
0 & 44 \\
1 & 82 \\
2 & 133 \\
3 & 165 \\
4 & 183 \\
5 & 193 \\
6 & 200 \\
7 & 203 \\
8 & 205 \\
9 & 206 \\
10 & 208 \\
\hline
\end{tabular}




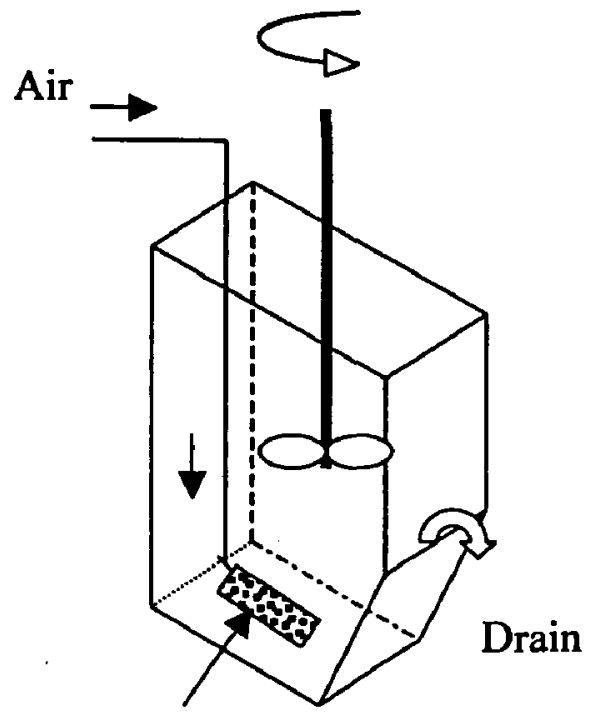

Air diffuser

Figure 3.7. Schematic diagram of sequential batch reactor tank (SBR). Working volume $=7 \mathrm{~L}$. 
The probe should be placed in moist air and the meter should be adjusted corresponding to the calibration value for the local altitude. Meter accuracy is about $\pm 0.1 \mathrm{mg} / \mathrm{L}$, and the temperature sensor accuracy is $+0.2^{\circ} \mathrm{C}$.

To measure the DO when there is no movement in the system; a clean magnetic stirring bar should be placed in each container to mix it. The magnetic should not be removed until the end of the DO reading.

\subsubsection{Biological Oxygen Demand (BOD)}

BOD depends on the biodegradability of the waste and can identify the amount of oxygen that is necessary to oxidize a waste biologically into $\mathrm{CO}_{2}$ and water during a specific period of incubation. This parameter can measure the biodegradable organic carbon that is present in the waste along with oxidizable nitrogen. The low value of BOD either shows very clean water or a toxic wastewater which can inhibit microorganisms from growth. The most popular BOD test is 5-day BOD, which measures the amount of oxygen used in 5 days to stabilize the organics in wastewater incubating at $20^{\circ} \mathrm{C}$. However, measuring the oxygen required to oxidize the organic matter completely is also possible. This type of BOD is referred to as ultimate BOD (UBOD). It is important to know that BOD is the combination of two parameters, the oxygen used for synthesis of new cells and endogenous respiration. BOD can also be expressed mathematically by assuming a first order reaction rate as follows (Metcalf and Eddy, 2002):

$$
\frac{d l}{d t}=-k l
$$

where $\mathrm{l}, \mathrm{k}$, and $\mathrm{t}$ are the amount of oxygen demand at time $\mathrm{t}$, reaction rate constant, and reaction duration, respectively.

Equation (3.4) can be simplified as follows:

$$
l=l_{0} e^{-k l}
$$


where $l_{0}$ is the oxygen required to oxidize the biodegradable organics totally or UBOD. Moreover, to find the amount of BOD at any time, the following equation can be defined:

$B O D_{1}=l_{o}-l$

where $\mathrm{BOD}_{\mathrm{t}}$ is the amount of $\mathrm{BOD}$ at time $\mathrm{t}$.

Substituting Equation (3.5) into Equation (3.6), BOD at time $t$ can be calculated directly.

$$
B O D_{t}=l_{o}\left(1-e^{-k t}\right)
$$

The method consists of providing nutrient and oxygen for the microorganisms to oxidize a specific volume of organic wastes in a sealed $300 \mathrm{ml}$ bottles placing in an incubator at $20^{\circ} \mathrm{C}$ for 5 days. The $\mathrm{BOD}_{5}$ is calculated by the difference in the initial dissolved oxygen (DO) and the DO after 5 days. However, if the sample has been diluted, the dilution factor should be taken into account.

Dilution water was prepared by adding $1 \mathrm{~mL}$ of each nutrient (Section 3.1.6) to one liter of distilled water and aerating the water for at least half an hour. The seed solution (Section 3.1.8) was prepared by adding one capsule of polyseed to $500 \mathrm{~mL}$ of dilution water. The solution was aerated for one hour. This solution was then allowed to settle for 5-15 minute prior to use. Five $\mathrm{mL}$ of seed solution was added to each $300 \mathrm{~mL}$ BOD bottles (VWR Science). The mixture was diluted with dilution water. The bottles were water sealed and placed in dark incubator at $20^{\circ} \mathrm{C}$ to prevent oxygen transfer. The volume of the waste added to each bottle can be estimated according to Table 3.1. The initial DO (dissolved oxygen) and DO after 5 days were measured using an YSI 58 dissolved oxygen meter (3.2.8). A blank solution was prepared by diluting $5 \mathrm{ml}$ of seed solution in the BOD bottle with dilution water and again its initial DO and DO after 5 days were measured. The $\mathrm{BOD}_{5}$ was calculated according to the following equation:

$B O D_{5}=\frac{\left(D O_{s 1}-D O_{s 2}\right)-\left(D O_{B 1}-D O_{B 2}\right) f}{P}$ 
where $\mathrm{DO}_{\mathrm{s} 1}, \mathrm{DO}_{\mathrm{s} 2}, \mathrm{DO}_{\mathrm{B} 1}, \mathrm{DO}_{\mathrm{B} 2}, \mathrm{f}$, and $\mathrm{P}$ are initial $\mathrm{DO}$ of sample, $\mathrm{DO}$ of sample after 5 days, initial DO of blank, DO of blank after 5 days, ratio of seed in diluted sample to seed in seed control, and volumetric fraction of sample used, respectively. $\mathrm{P}$ can also be defined as the ratio of volume of sample added to the bottles, to $300 \mathrm{~mL}$ (volume of bottles). As BOD test can be influenced by presence of toxicants, improper use of seeding, and error in analytical techniques, it was checked periodically by a standard check solution (3.1.7). Therefore, for a $2 \%$ dilution of such a solution, the $\mathrm{BOD}_{5}$ would be $198 \mathrm{mg} / \mathrm{L}$ with a standard deviation of $30.5 \mathrm{mg} / \mathrm{L}$ (Standard Methods, 1998).

After each use, the bottles should be cleaned by detergent and dilute $\mathrm{HCl}(3 \mathrm{~N})$ to remove any surface film, and covered with paper to prevent collecting dust.

\subsubsection{Ultimate Biological Oxygen Demand (UBOD)}

Ultimate Biological Oxygen Demand test is almost the same as $\mathrm{BOD}_{5}$ test explained before, but with a few different steps. In this method, the bottles should be kept in incubator under the above mentioned conditions for an extended period of time depending on the type of wastewater. The dissolved oxygen should be measured initially and frequently to ensure that the DO is not low and anaerobic condition has not been occurred. If the concentration of dissolved oxygen reaches around $2 \mathrm{mg} / \mathrm{L}$, the sample should be aerated again.

Dissolved oxygen should be measured at intervals of 2 to 5 days over a period of 30 to 60 days. When DO falls around $2 \mathrm{mg} / \mathrm{L}$ a small amount of sample should be poured into a beaker and reaerated with air. The new DO should also be recorded. If dilution water blank is used, it should follow the same procedure and the total DO consumed must be subtract from the blank's DO uptake.

Ultimate BOD can be estimated by using Equation (3.7), which can also be expressed in the form of:

$$
B O D_{1}=U B O D\left(1-e^{-k t}\right)
$$


Table 3.2: The volume of wastewater added to the bottles for BOD measurement (Metcalf and Eddy, 2003).

\begin{tabular}{|c|c|}
\hline BOD range & mL of sample adding to BOD bottle \\
\hline $300-1050$ & 2 \\
\hline $120-420$ & 5 \\
\hline $60-120$ & 10 \\
\hline $30-100$ & 20 \\
\hline $12-42$ & 50 \\
\hline $6-20$ & 100 \\
\hline $0-7$ & 300 \\
\hline
\end{tabular}


where $\mathrm{BOD}_{\mathrm{t}}, \mathrm{k}, \mathrm{t}$, and $\mathrm{UBOD}$ are the amount of $\mathrm{BOD}$ at time $\mathrm{t}$, reaction rate constant, reaction duration, and $\mathrm{UBOD}$ is the ultimate biological oxygen demand, respectively.

\subsubsection{Hydrogen Peroxide Measurement}

The residual $\mathrm{H}_{2} \mathrm{O}_{2}$ can interfere with $\mathrm{COD}$ measurements due to its reaction with dichromate. Therefore, this reaction could increase the measured COD, as it was observed that $1 \mathrm{mg} / \mathrm{L}$ of residual $\mathrm{H}_{2} \mathrm{O}_{2}$ could generate $0.26 \mathrm{mg} / \mathrm{L}$ COD (Lin et al., 1998). Moreover, $\mathrm{H}_{2} \mathrm{O}_{2}$ is known to be bactericides and inhibitor in the bacteria activity. Therefore residual $\mathrm{H}_{2} \mathrm{O}_{2}$ can inhibit the bacterial growth in the $\mathrm{BOD}$ tests, and hence, underestimate actual BOD. Removal of residual $\mathrm{H}_{2} \mathrm{O}_{2}$ is sifically important for the biological treatment step that is fed by pre-treated $\mathrm{UV} / \mathrm{H}_{2} \mathrm{O}_{2}$ process.

The concentration of $\mathrm{H}_{2} \mathrm{O}_{2}$ was measured by two methods:

1. DMP method (2,9-dimethyl-1,10-phenanthroline)

2. DPD method (N,N-diethyl-p-phenylenediamine)

The detection limit for DMP method was 3.4-170 mg/L and for DPD method was 0.1-40 $\mathrm{mg} / \mathrm{L}$.

DPD method has DPD reagent tablets, which are commercially available with a colorimetric kit. It was used when lower concentration of $\mathrm{H}_{2} \mathrm{O}_{2}$ was expected. On the other hand, DMP method was used when precise determination was desirable and the $\mathrm{H}_{2} \mathrm{O}_{2}$ concentration was not expected to be very low. The DMP procedure is based on the reduction of copper(II) with $\mathrm{H}_{2} \mathrm{O}_{2}$ and production of a stable bright yellow complex of $\mathrm{Cu}(\mathrm{DMP})_{2}{ }^{+}$with maximal absorbance at $454 \mathrm{~nm}$ (Kosaka et al., 1998). The test procedures are as follows:

One $\mathrm{mL}$ of each of the reagent solutions describe in Section 3.1 .9 were added to a $10 \mathrm{~mL}$ volumetric flask and mixed well. Three $\mathrm{mL}$ of sample was added to the flask and diluted with distilled water to $10 \mathrm{~mL}$. After mixing, the absorbance of the sample was measured at $454 \mathrm{~nm}$. Blank solution was prepared in the same way but with distilled water instead of sample. To make a calibration curve, different standards with different concentrations of $\mathrm{H}_{2} \mathrm{O}_{2}$ were prepared and their absorbance was measured at $454 \mathrm{~nm}$. Therefore, the 
concentration of the samples could be read directly from the calibration curve (Figure 3.8).

\subsubsection{Mixed Liquor Suspended Solids (MLSS)}

Mixed liquor suspended solids (MLSS) is a quantitative way to measure the concentration of solids in sludge. It is done by filtering a known volume of sludge using Whatmann glass fiber filter with the pore diameter of $1.58 \mathrm{~m}$. The solids remain on the filter should be dried at $150^{\circ} \mathrm{C}$ and reported in terms of $\mathrm{mg} / \mathrm{L}$ of dried solids. If this filter is burned in oven at $550^{\circ} \mathrm{C}$, what is obtained, is mixed liquor fixed suspended solids, and what is burned off is mixed liquor volatile suspende 1 .o'ids (MLVSS). Therefore, the mass of organics in the sludge could be calculated. Generally, MLVSS is used as the biomass in the activated sludge.

\subsubsection{Shake Flask Tests for Biodegradation of LAS}

Shake flask tests were performed to quantify the biodegradation of untreated LAS with the initial concentration of $100 \mathrm{mg} / \mathrm{L}$ and pre-treated LAS. Experiments were conducted in $300 \mathrm{~mL}$ flasks, and stoppered with a ball of cotton to allow consistent aeration. Flasks were filled with $200 \mathrm{~mL}$ of LAS solution and diluted to $300 \mathrm{~mL}$. The aerobic nutrient medium was prepared by $\mathrm{KH}_{2} \mathrm{PO}_{4}, \mathrm{~K}_{2} \mathrm{HPO}_{4}, \mathrm{NaHPO}_{4} .7 \mathrm{H}_{2} \mathrm{O}, \mathrm{NH}_{4} \mathrm{Cl}$, $\mathrm{MgSO}_{4}, \mathrm{FeCl}_{3}$, and $\mathrm{CaCl}_{2}$ (Standard methods, 1998). $0.5 \mathrm{~mL}$ of each of the nutrient solution described in Section 3.1.6 was added to each flask. $50 \mathrm{~mL}$ activated sludge (from North Toronto Treatment Plant, located in the Don Valley) was fed to the flasks, and the whole solution in the flask was diluted to $300 \mathrm{~mL}$. Each flask was prepared in duplicates. Following addition of all materials, the solution inside the flasks was stirred vigorously for one minute prior to take the first sample. Then, the flasks were incubated in the shaker incubator $(150 \mathrm{rpm})$ and at a controlled temperature of $20^{\circ} \mathrm{C}$. During the sampling, the flask was mixed vigorously with a magnetic stirrer.

\subsubsection{Biological Treatment of LAS using Sequential Batch Reactors}

An aerobic sequential batch reactor (Figure3.7) was used to generate acclimated biomass for biological treatment of LAS. 


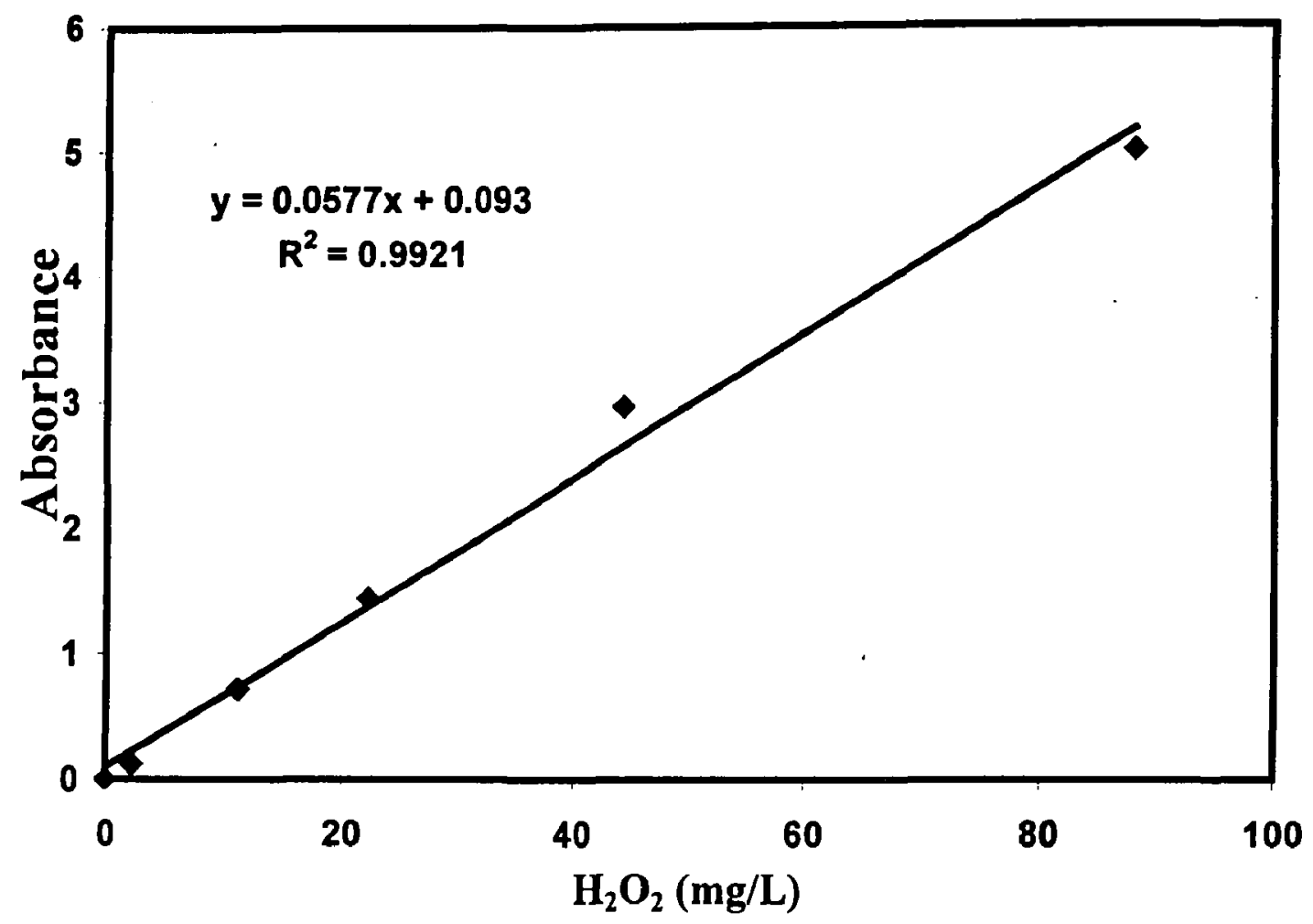

Figure 3.8. Calibration curve for determination of $\mathrm{H}_{2} \mathrm{O}_{2}$, based on DMP method. Absorbance, or optical density, is a measure of the amount of light absorbed by a solution. Absorbance is equal to the logarithm of the ratio of incident light to transmitted light. 
The objective of this experiment was to adapt the biomass to a certain concentration of LAS. The effect of acclimation on the biodegradability of LAS was studied. To increase the rate of biomass growth during the acclimation period, LAS was diluted with sodium acetate. This dilution was based on the initial characteristic of LAS. The $\mathrm{BOD}_{5}$ of LAS at that concentration should be measured. Therefore, the dilution should be in a way to provide the same $\mathrm{BOD}_{5}$. The experiment was started by addition of sodium acetate with a $\mathrm{BOD}_{5}$ equal to the $\mathrm{BOD}_{5}$ of that concentration of LAS to the reactor. Moreover, activated sludge (from North Toronto Treatment Plant) and nutrient with the ratio of BOD:N:P equal to 100:5:1 were fed to the reactor. The nutrient medium was composed of $\mathrm{KH}_{2} \mathrm{PO}_{4}, \mathrm{~K}_{2} \mathrm{HPO}_{4}, \mathrm{NaHPO}_{4} .7 \mathrm{H}_{2} \mathrm{O}, \mathrm{NH}_{4} \mathrm{Cl}, \mathrm{MgSO}_{4}, \mathrm{FeCl}_{3}$, and $\mathrm{CaCl}_{2}$ (Standard Methods, 1998). Thirty one $\mathrm{mL}$ phosphate buffer and $1.4 \mathrm{~mL}$ from each of the $\mathrm{MgSO}_{4}, \mathrm{FeCl}_{3}$, and $\mathrm{CaCl}_{2}$ was added to the SBR. The nutrients were added to the system weekly. Air was provided by air diffuser, and the system was mixed at the speed of 300 rpm. The concentration of LAS in the substrate was gradually increased from 0 to 10 $\mathrm{mg} / \mathrm{L}$ during 23 days; meanwhile, the concentration of sodium acetate was decreased to maintain the pervious $\mathrm{BOD}_{5}$. The addition of new substrate was provided when the changes in the concentration of LAS in the reactor became steady state, in other words the concentration of LAS became zero. The duration of each phase was as follows: Fill phase $6 \mathrm{~h}$ with aeration, react phase $8.4 \mathrm{~h}$ with mixing and aeration, settle phase $4.8 \mathrm{~h}$ with no aeration or mixing, draw phase $3.6 \mathrm{~h}$ with no aeration or mixing, and idle phase $1.2 \mathrm{~h}$ with only aeration. The duration of each cycle was $24 \mathrm{~h}$. the sample was taken at the end of the settled phase and if the concentration of LAS was zero, new feed (according to the explanation mentioned above) was introduced to the system. After the last feed (10 $\mathrm{mg} / \mathrm{L}$ LAS) was given to the system and was consumed by the microorganisms in the activated sludge, the whole liquor was drained at the end of settled phase but the sludge was kept inside the reactor. The reactor was filled with the fresh sample (could be either untreated LAS or LAS with photolytic pre-treatment). Nutrients as described before were added to the system. The duration of each phase was the same as before and the percentage of removal of LAS at the end of each phase was monitored. 


\section{CHAPTER 4}

\section{RESULTS AND DISCUSSIONS}

In this chapter, the results obtained from photochemical and biological degradation of linear alkylbeneze sulfonate (LAS) using a pilot plant photoreactor and a sequential batch reactor are presented and discussed. LAS at the concentration of 100 $\mathrm{mg} / \mathrm{L}$ was degraded by UV-254 and combination of $\mathrm{UV}$ and $\mathrm{H}_{2} \mathrm{O}_{2}$ to determine which one has the ability to degrade LAS at a faster rate. Moreover, different experiments were carried out to determine the best working condition for the pilot plant photoreactor. Different experiments on biological treatment of LAS were conducted under aerobic conditions. In conclusion, combination of chemical and biological treatment was examined.

\subsection{Photolytic Treatment of LAS}

\subsubsection{Free Chlorine}

The degradation of LAS in the presence and absences of free chlorine was compared in the photolytic reactor (Figure 4.1). Two conditions were examined, with and without mixing in the system. It was observed that:

1. Mixing increased the degradation rate of LAS with free chlorine by $7 \%$, and without free chlorine by $10 \%$, compared to non-mixing system.

2. The degradation of LAS had an increase using tap water containing free chlorine in the system by $5 \%$ with mixing, and $8 \%$ without mixing.

Therefore, it was concluded that free chlorine could react as an oxidant under UV light, and increase the reaction rate. Figure 4.2 compares the initial rate for those four different cases. The presence of free chlorine $(0.8 \mathrm{mg} / \mathrm{L})$ in the system and having mixing in the photoreactor has the highest rate $(0.8 \mathrm{mg} / \mathrm{L} \cdot \mathrm{min})$ comparing to the rest of the cases. Although, the presence of free chlorine in each case (with mixing or without mixing) had 


\section{Stabilization}

period (lights off)

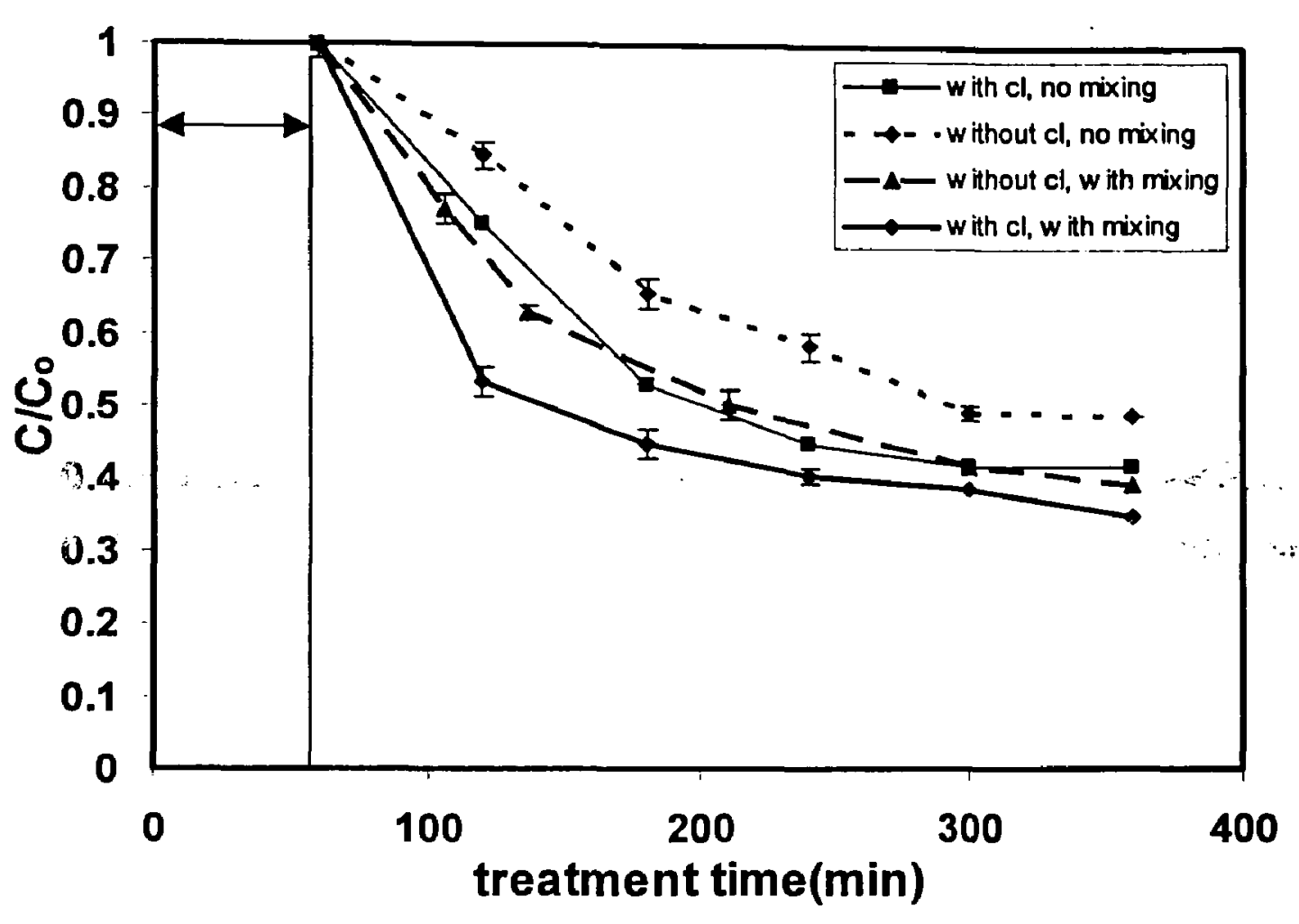

Figure 4.1: Difference between the photolytic degradation of LAS in the presence and absence of free chlorine. Flow rate $=8 \mathrm{~L} / \mathrm{min}$, initial concentration of LAS $=100 \mathrm{mg} / \mathrm{L}$. Two different conditions, with and without mixing are compared in the reactor. Total illumination time was $300 \mathrm{~min}$.

Three separate samples were taken and analyzed, in which case the standard deviations (error bars) represent sampling, preparation, and instrument error. 


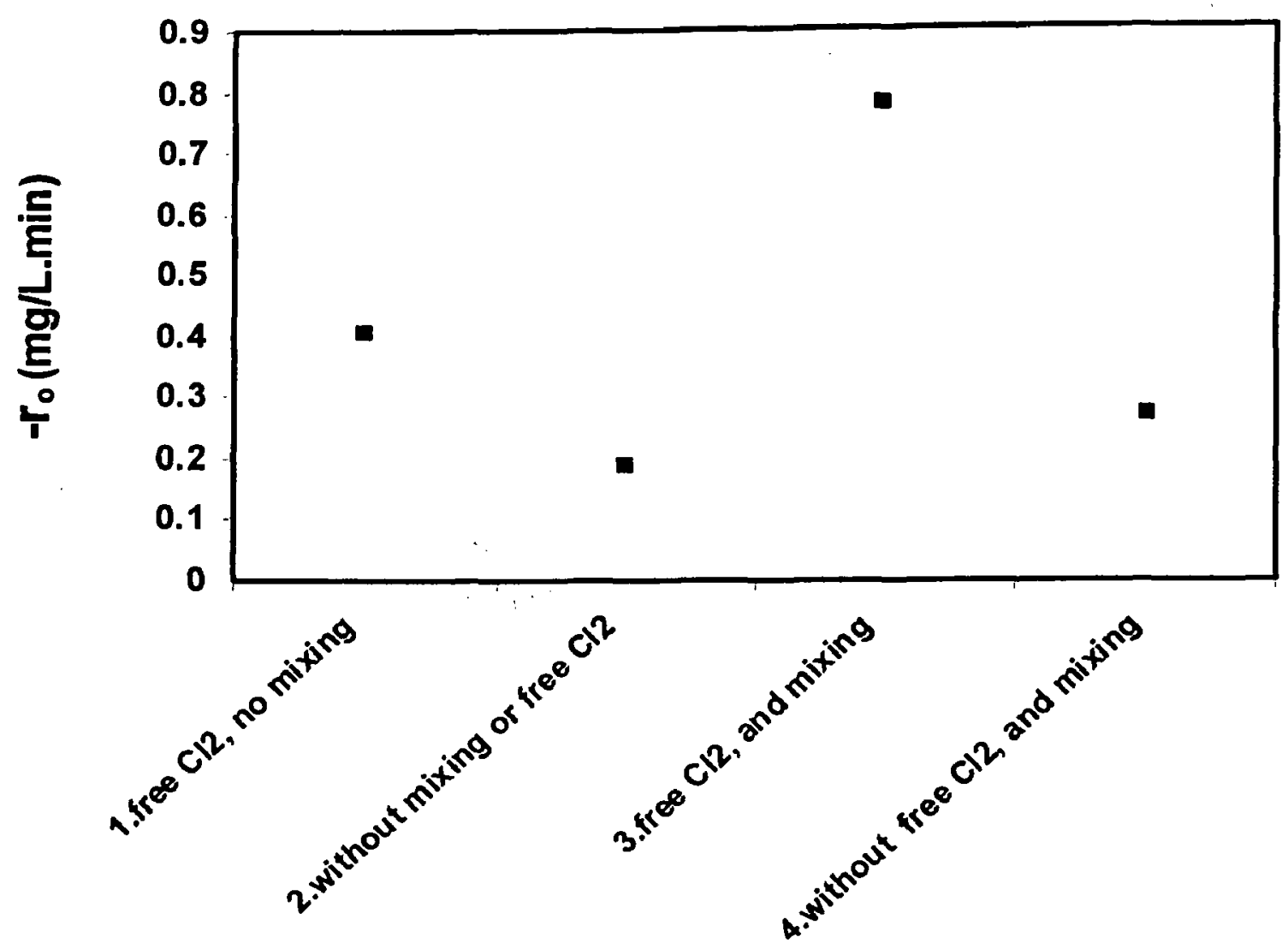

Figure 4.2: Comparing the initial rate for four different cases in photolytic degradation of LAS in the presence and absence of free chlorine. Flow rate $=8 \mathrm{~L} / \mathrm{min}$, initial concentration of $\mathrm{LAS}=100 \mathrm{mg} / \mathrm{L}$. Four cases are as follows:

1- presence of free chlorine but no mixing

2- presence of free chlorine and mixing

3- absence of free chlorine but no mixing

4- absence of free chlorine and mixing. 
shown higher removal of LAS, as the initial rate in the presence of free chlorine in the system without mixing is $0.4 \mathrm{mg} / \mathrm{L} \cdot \mathrm{min}$, while this rate is $0.2 \mathrm{mg} / \mathrm{L} \cdot \mathrm{min}$ for the case of without free chlorine. However, this variation is much more in the presence of mixing in the system, as the initial rate in the presence of free chlorine in the system with mixing is $0.8 \mathrm{mg} / \mathrm{L} \cdot \mathrm{min}$, while this rate is $0.27 \mathrm{mg} / \mathrm{L} \cdot \min$ for the case of mixing but without the presence of free chlorine .

\subsubsection{Dark Reaction}

It was observed that there were no significant changes in the concentration of LAS during the dark reaction (Figure 4.3). Therefore, LAS is neither degraded nor adsorbed in the absence of UV lights. This experiment was conducted with two different initial concentrations of LAS to compare the effects of initial concentration on the degradation during dark reaction. In Figure 4.3, the changes for the initial concentration of $95 \mathrm{mg} / \mathrm{L}$ and $65 \mathrm{mg} / \mathrm{L}$ of LAS were monitored and it was observed that there no significant changes in the concentration of LAS.

There was a concern that the concentration of LAS might decrease due to foaming of LAS after $6 \mathrm{~h}$. It was observed that the foaming was increased rapidly from the beginning of the experiment and it was believed that these foams contain an excess of surfactant. However, sampling from the bulk of liquid phase for 6 hours did not show any differences in the concentrations of LAS from beginning until the end of the experiment (Figure 4.3).

After elimination of free chlorine from the tap water inside the feed tank, sufficient LAS was added to the feed tank to make a $100 \mathrm{mg} / \mathrm{L}$ of LAS solution. The experiment was not started after addition of flaked LAS to the water, as LAS should be mixed in the tank to produce a uniform concentration throughout the feed tank. Moreover, the temperature of water may not be exactly $20^{\circ} \mathrm{C}$, which is the operating temperature. Therefore, the solution was mixed thoroughly in the system for one hour (dark reaction). During this period of time, the temperature of the system was kept at $20^{\circ} \mathrm{C}$ prior to turning on the UV lamps. 


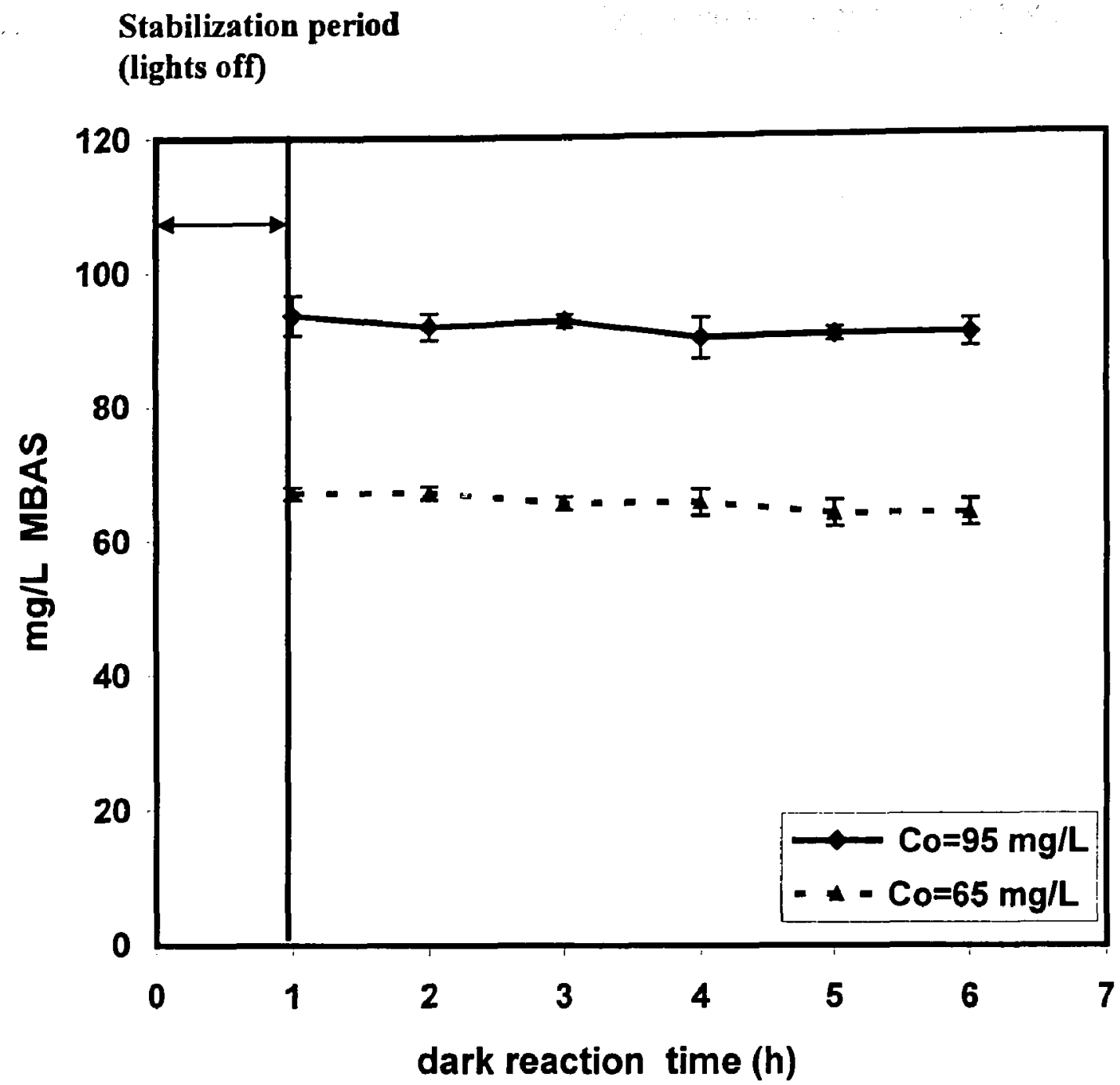

Figure 4.3: Changes in the concentration of LAS during dark reaction. Two different initial concentrations of LAS were examined. Three separate samples were taken and analyzed, in which case the standard deviations (error bars) represent sampling, preparation, and instrument error. 
During the dark reaction, the concentration of LAS did not change, furthermore, if the duration of stabilization period was known, the experiment could be run with the precise concentration of LAS. Sampling was started exactly after addition of a known amount of LAS to the water. Therefore, the changes in the concentration of LAS from the time of the addition until achieving to the equilibrium concentration of LAS were monitored. As it is shown in Figure 4.4, the concentration of LAS was about $87 \mathrm{mg} / \mathrm{L}$ after a few second of addition of $10 \mathrm{~g}$ of flaked LAS to the water inside the feed tank and reached to 100 $\mathrm{mg} / \mathrm{L}$ after $45 \mathrm{~min}$. Therefore, the optimum stabilization time prior to the start of each run was $45 \mathrm{~min}$ to one hour. Moreover, it took about $45 \mathrm{~min}$ for the system's temperature to reach to $20^{\circ} \mathrm{C}$. This period of time could vary depending on the temperature of water being used.

\subsubsection{Photoreaction of LAS by UV-254}

The flow rate and also the mixing speed were changed during the experiment and the effects of these parameters on the photolytic degradation rate of LAS were studied. In this experiment, all conditions were kept the same as to those of the dark reaction except that the $6 \mathrm{UV}$ lamps were turned on simultaneously after the stabilization period. Furthermore, the temperature of the reactor was kept constant at $20^{\circ} \mathrm{C}$ using the water bath, during all the experiment, therefore, the effect of increasing the temperature due to the UV lamps have been eliminated. Three Samples were taken every hour and analyzed immediately. The initial concentration of LAS was $100 \mathrm{mg} / \mathrm{L}$. The flow rate and also the mixing speed were changed during the experiment. Therefore, the effects of changing both of those parameters on the photolytic degradation rate of LAS were studied.

\subsubsection{Effects of Flow Rate}

Experiments were carried out to compare the effects of flow rate on the photolytic degradation of LAS with a constant mixing speed for all of the runs. The ranges of flow rates were varied from $4-40 \mathrm{~L} / \mathrm{min}$. Lower and higher flow rates were not 


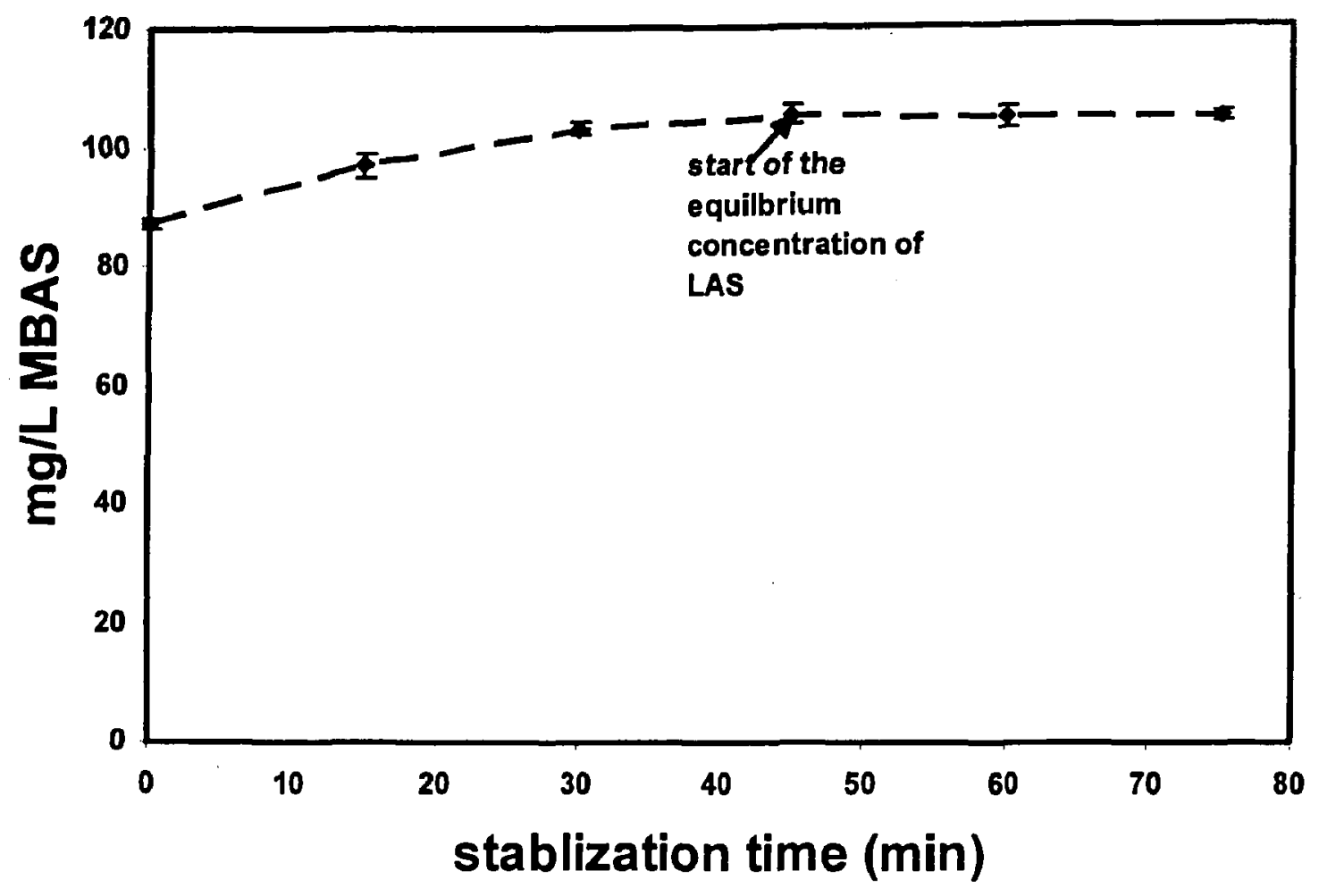

Figure 4.4: LAS concentration in the stabilization period prior to the start of each experiment. During this period the whole system was running, but with no UV light Three separate samples were taken and analyzed, in which case the standard deviations (error bars) represent sampling, preparation, and instrument error. 
applied due to the system limitations and excessive foaming problem inside the flow meter, which made the flow rate inconsistent.

Figure 4.5 illustrates the flow rate of $8 \mathrm{~L} / \mathrm{min}$ has the highest initial rate $\left(5 \times 10^{-5}\right.$ $\mathrm{mg} / \mathrm{L} . \mathrm{h})$, while the flow rate of $32 \mathrm{~L} / \mathrm{min}$ has the lowest $\left(3 \times 10^{-5} \mathrm{mg} / \mathrm{L} . \mathrm{h}\right)$. It implies that the rate of reaction of the lowest flow rate is faster; hence, it can degrade more than the rest of the flow rates in a given period of time. At flow rate of $8 \mathrm{~L} / \mathrm{min}$, LAS can be degraded by $75 \%$ during 6 hours. That can be due to the increase in the residence time by decreasing the flow rate, which gives more time to the organics exposed to illumination. There ore, UV with the wavelength of $254 \mathrm{~nm}$ has more time to break the bonds. However, as the whole system is batch and more than $75 \%$ of solution inside the feed tank would enter the photoreactor in each cycle, the above mentioned reason might not be reasonable for increasing the initial rate by increasing the flow rate. On the other hand, by increasing the flow rate there is an increase in the amount of foams in the system. The foams might also work as a barrier in higher flow rates to hinder the light from being absorbed by the solution.

First order model was tried for the photolytic degradation of LAS and it was observed that the photolytic degradation of LAS did not follow that model. The reason might be due to the occurrence of two reactions simultaneously. One reacts with slower rate and the other with a faster rate. Therefore, a double exponential model (combination of two first order model) might be a good choice. The other reason for not following first order model might be due to the fact that MBAS method measures all of the anionic compounds that were produced during the photolytic degradation of LAS.

\subsubsection{Effect of Mixing Speed on the Photolytic Degradation of LAS}

It was observed that the degradation of LAS was increased by increasing the mixing speed. This is due to the production of turbulent flow in the system which increases the mass transfer rate inside the reactor. The turbulent flow was initiated after $165 \mathrm{rpm}$ and the sharp increase in the initial rate of reaction after $165 \mathrm{rpm}$ could be due to 


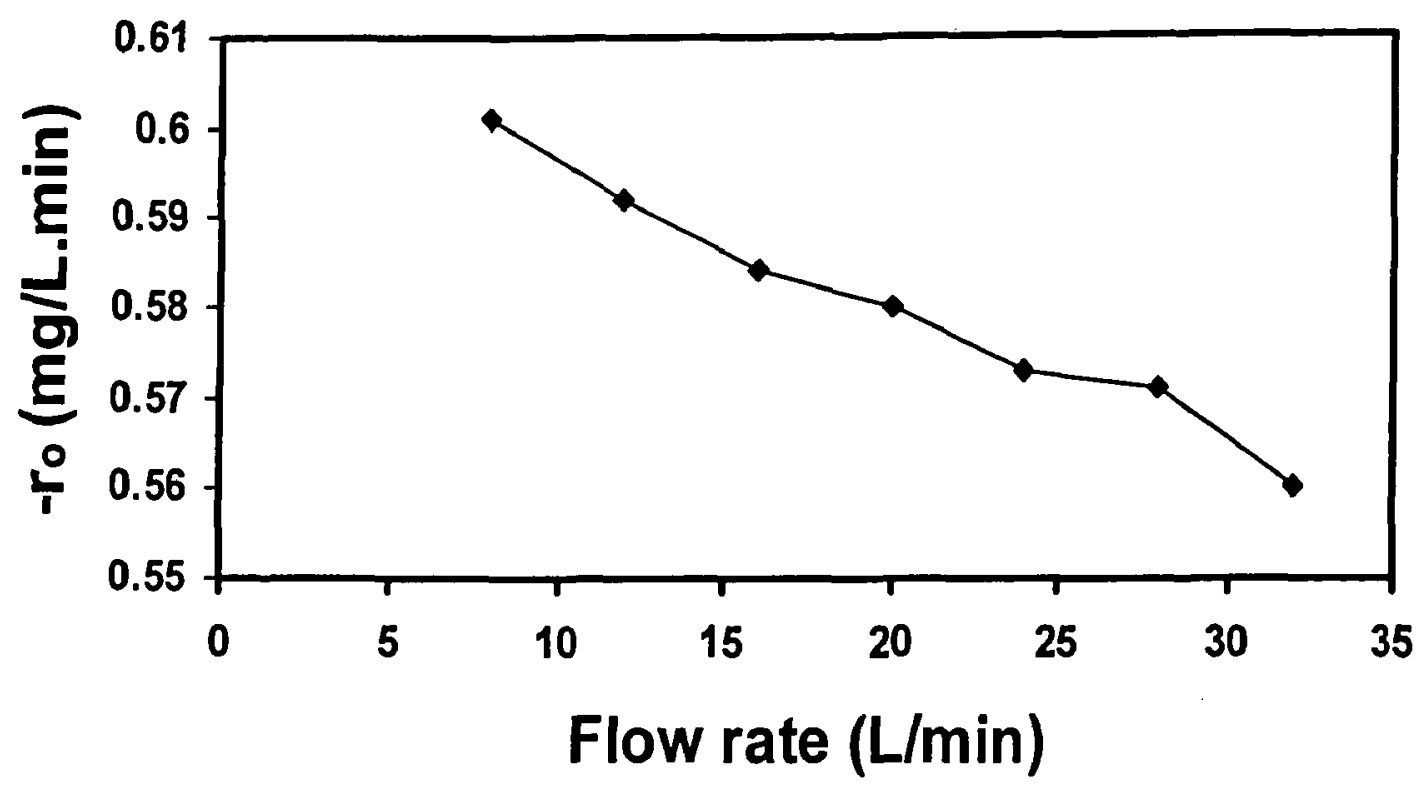

Figure 4.5: The initial rate for photolytic degradation of LAS. Different flow rates at a constant mixing speed were examined. Initial concentration of LAS was $100 \mathrm{mg} / \mathrm{L}$. 
the turbulent flow. To predict the type of flow, Reynolds number's calculation was based on the assumption that there is no other movement inside the reactor except for the mixing. Therefore, the lowest flow rate was chosen to produce a laminar flow inside the reactor which gave Reynolds number equal to 132 . . It was observed that at $165 \mathrm{rpm}$ the Reynolds number reached to 2750 , which is in the range of turbulency. While the Reynolds numbers for the lower mixing speeds have not reached to the turbulence zone. Water flow could also produce small channels within the photoreactor that allows the water to pass rapidly through the reactor without coming into contact with the UV lights.

Figure 4.6 shows that the initial rate of degradation was increased by increasing the mixing speed. However, there was almost no difference between the photolytic degradation by changing the speed from 7-10, as the rotational speed for those numbers are almost the same (Table 3.1). The maximum degradation occurred by trying the maximum mixing speed was $80 \%$ in 6 hours.

\subsubsection{Optimization of $\mathrm{H}_{2} \mathrm{O}_{2}$ for Degradation of LAS}

UV alone could degrade the LAS up to maximum $80 \%$ during $6 \mathrm{~h}$. In the next experiments the effects of $\mathrm{H}_{2} \mathrm{O}_{2}$ on the photolytic degradation of LAS were examined. In order to speed up the degradation rate of LAS, sufficient $\mathrm{H}_{2} \mathrm{O}_{2}$ is essential so that it can absorb UV light and generates sufficient hydroxyl radicals. Therefore, different concentrations of $\mathrm{H}_{2} \mathrm{O}_{2}$ were used, while the initial concentration of LAS was kept constant. Figure 4.7 shows that $\mathrm{H}_{2} \mathrm{O}_{2}$ has the ability to degrade LAS rapidly. Therefore, the reaction time was $4.5 \mathrm{~h}$ shorter than that of the previous experiments using $\mathrm{UV}$ alone. The addition of $120 \mathrm{mg} / \mathrm{L} \mathrm{H}_{2} \mathrm{O}_{2}$ could degrade LAS up to $80 \%$ at two hours, while increasing the concentration of $\mathrm{H}_{2} \mathrm{O}_{2}$ led to increase in the degradation rate. In order to find the optimum concentration for the hydrogen peroxide, a pseudo-first order model with respect to the concentration of LAS was assumed (Figure 4.8). The degradation constant was increased by increasing the dosage of $\mathrm{H}_{2} \mathrm{O}_{2}$, but increasing the concentration beyond $720 \mathrm{mg} / \mathrm{L}$ showed negative effect on the LAS degradation. Therefore, the optimum concentration of $\mathrm{H}_{2} \mathrm{O}_{2}$ was about $720 \mathrm{mg} / \mathrm{L}$. Higher concentration of $\mathrm{H}_{2} \mathrm{O}_{2}$ led to a decrease in degradation rate of LAS. 


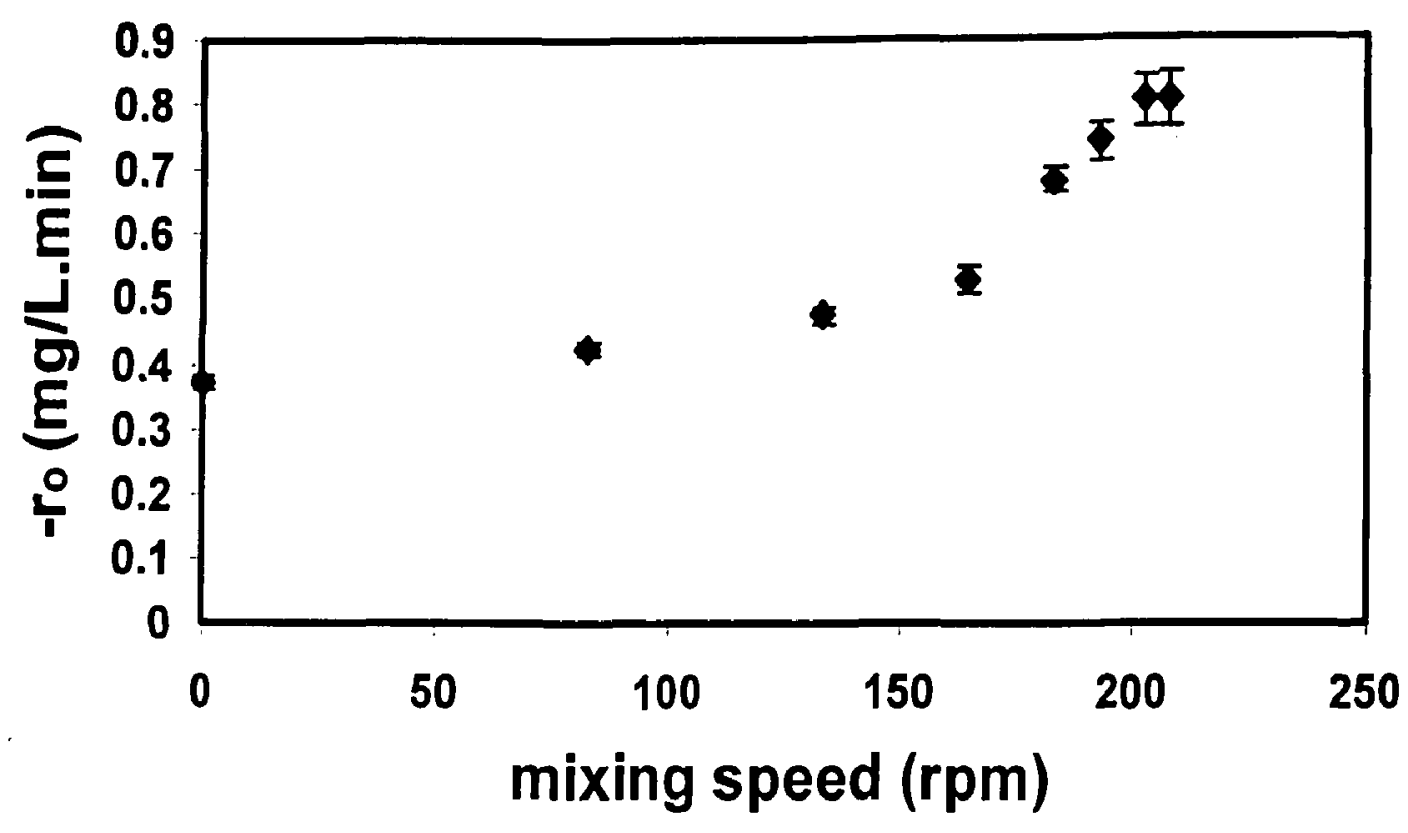

Figure 4.6: Initial rate for of photolytic degradation of LAS versus changing the mixing speed. Initial concentration of $\mathrm{LAS}=100 \mathrm{mg} / \mathrm{L}$, flow rate for all cases was $8 \mathrm{~L} / \mathrm{min}$. Three separate samples were taken and analyzed, in which case the standard deviations (error bars) represent sampling, preparation, and instrument error. 


\section{Stabilization period}

(lights off)

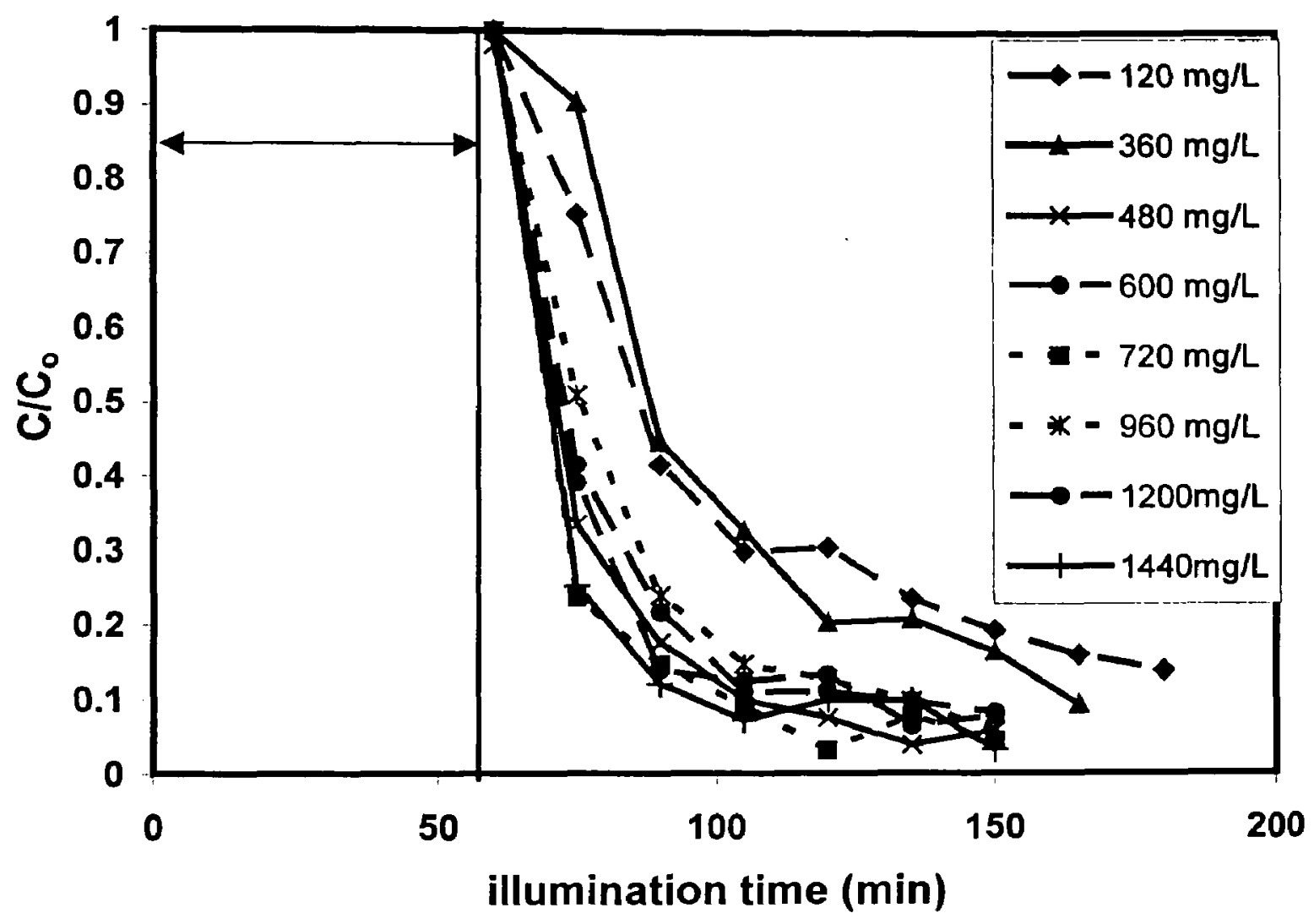

Figure 4.7: Effects of UV- $\mathrm{H}_{2} \mathrm{O}_{2}$ on LAS removal, flow rate: $12 \mathrm{~L} / \mathrm{min}$, mixing speed $=183 \mathrm{rpm}, \mathrm{C}_{0}=100 \mathrm{mg} / \mathrm{L}$. Different concentrations of $\mathrm{H}_{2} \mathrm{O}_{2}$ had been examined. 


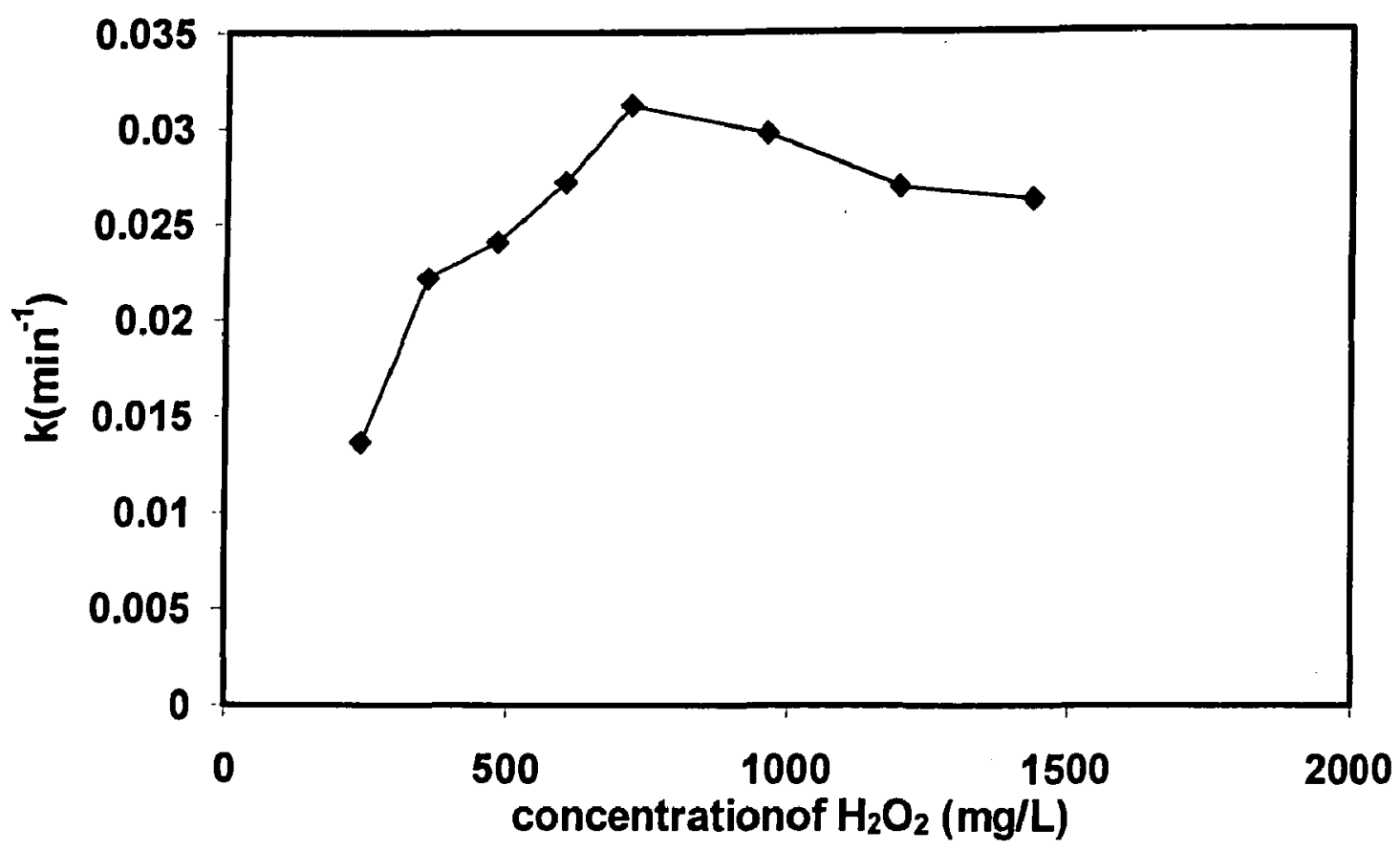

Figure 4.8: Optimum concentration of $\mathrm{H}_{2} \mathrm{O}_{2}$ assuming a pseudo-first order model for the photolytic degradation of LAS with $\mathrm{H}_{2} \mathrm{O}_{2}$. First order model constants for different concentrations of $\mathrm{H}_{2} \mathrm{O}_{2}$.

The initial concentration of LAS was $100 \mathrm{mg} / \mathrm{L}$ and flow rate $=12 \mathrm{LPM}$, mixing speed $=183 \mathrm{rpm}$. 
This could be due to the following reasons (Ledakowicz and Gonera, 1999):

1. Auto-oxidation of $\mathrm{H}_{2} \mathrm{O}_{2}$ into $\mathrm{O}_{2}$ and $\mathrm{H}_{2} \mathrm{O}$, and recombination of ${ }^{\circ} \mathrm{OH}$ by means of $\mathrm{H}_{2} \mathrm{O}_{2}$ according to the following reactions:

$$
2 \mathrm{H}_{2} \mathrm{O}_{2} \rightarrow 2 \mathrm{H}_{2} \mathrm{O}+\mathrm{O}_{2}
$$

2. The excess of $\mathrm{H}_{2} \mathrm{O}_{2}$ reacts with ${ }^{\circ} \mathrm{OH}$ competing with pollutants and, hence, decreasing the efficiency of the treatment.

$$
\begin{aligned}
& \mathrm{H}_{2} \mathrm{O}_{2}+{ }^{\cdot} \mathrm{OH} \rightarrow \mathrm{H}_{2} \mathrm{O}+{ }^{\cdot} \mathrm{O}_{2} \mathrm{H} \\
& k=3.3 \times 10^{7}(\text { mol.s })^{-1}
\end{aligned}
$$

Moreover, the concentration of an optimal $\mathrm{H}_{2} \mathrm{O}_{2}$ /pollutant molar ratio between 10 and 100 has been proposed (Parra et al., 2002). In this experiment this ratio was in that range as it was 72 (mole $\mathrm{H}_{2} \mathrm{O}_{2}$ /mole LAS). The ratio of $\mathrm{H}_{2} \mathrm{O}_{2}$ to LAS which would result to complete mineralization is $50: 1$, but what was obtained from experiment was $72: 1$. This difference might be due to the presences of intermediates which their reaction with ${ }^{\circ} \mathrm{OH}$ could increase this ratio.

\subsubsection{Model for the Degradation of LAS with $\mathrm{UV}+\mathrm{H}_{2} \mathrm{O}_{2}$}

It was observed that the photolytic degradation of LAS follows first order model (Figure 4.9). Therefore the concentration of LAS at any time during photolytic degradation using $\mathrm{H}_{2} \mathrm{O}_{2}$ can be expressed by the following model:

$$
\operatorname{Ln}\left(\frac{C}{C_{0}}\right)=-0.0326 t
$$

where the first order constant $(k)$ and $C_{0}$, the initial concentration of LAS, are equal to $0.0326 \mathrm{~min}^{-1}$ and $100 \mathrm{mg} / \mathrm{L}$, respectively. Therefore $\mathrm{C}$ is the concentration of LAS at time $\mathrm{t}(\mathrm{min})$ is as follows: 


$$
C=100 e^{-0.0326} t
$$

As there was only little decrease in the concentration of $\mathrm{H}_{2} \mathrm{O}_{2}$ during the degradation of LAS and its concentration was much more than the concentration of LAS during the degradation, the concentration of $\mathrm{H}_{2} \mathrm{O}_{2}$ was assumed constant, and hence, the degradation model for LAS follows pseudo first order reaction.

However monitoring the COD, showed only $20 \%$ decrease during the period of reaction. It was supposed that the degradation of LAS during that period of time had moved toward formation of organics rather than complete oxidation of LAS. However, TOC results are needed to determine the level of total mineralization of the organics.

\subsubsection{Photolytic Degradation of LAS by using UV-254, Optimum Concentration of $\mathrm{H}_{2} \mathrm{O}_{2}$, and their Combination}

The degradation of LAS was compared for the following conditions:

1. by the optimum concentration of $\mathrm{H}_{2} \mathrm{O}_{2}$ along with UV-254

2. by the optimum concentration of $720 \mathrm{mg} / \mathrm{L} \mathrm{H}_{2} \mathrm{O}_{2}$ alone

3. by UV-254 alone

In each of those conditions, the initial concentration of LAS was $100 \mathrm{mg} / \mathrm{L}$. After the illumination period of $120 \mathrm{~min}$, it was observed that $\mathrm{H}_{2} \mathrm{O}_{2}+\mathrm{UV}$ could remove LAS up to $95 \%$, while the LAS removal by $\mathrm{H}_{2} \mathrm{O}_{2}$ alone and UV alone were $13 \%$, and $41 \%$, respectively (Figure 4.10 ). To investigate the time necessary for the complete photolytic removal of LAS using optimum concentration of $\mathrm{H}_{2} \mathrm{O}_{2}$, the experiment was run until the concentration of LAS was $0.5 \mathrm{mg} / \mathrm{L}$ which is the maximum contamination level set by EPA. Therefore, the illumination time necessary to degrade LAS by this method was 180 $\min$ (Figure 4.11).

\subsection{7 $\mathrm{pH}$}

$\mathrm{pH}$ was monitored during all experiments. In all cases the $\mathrm{pH}$ was decreased. $\mathrm{pH}$ reduction was more significant in the case of treating LAS with $\mathrm{UV}+\mathrm{H}_{2} \mathrm{O}_{2}$. 


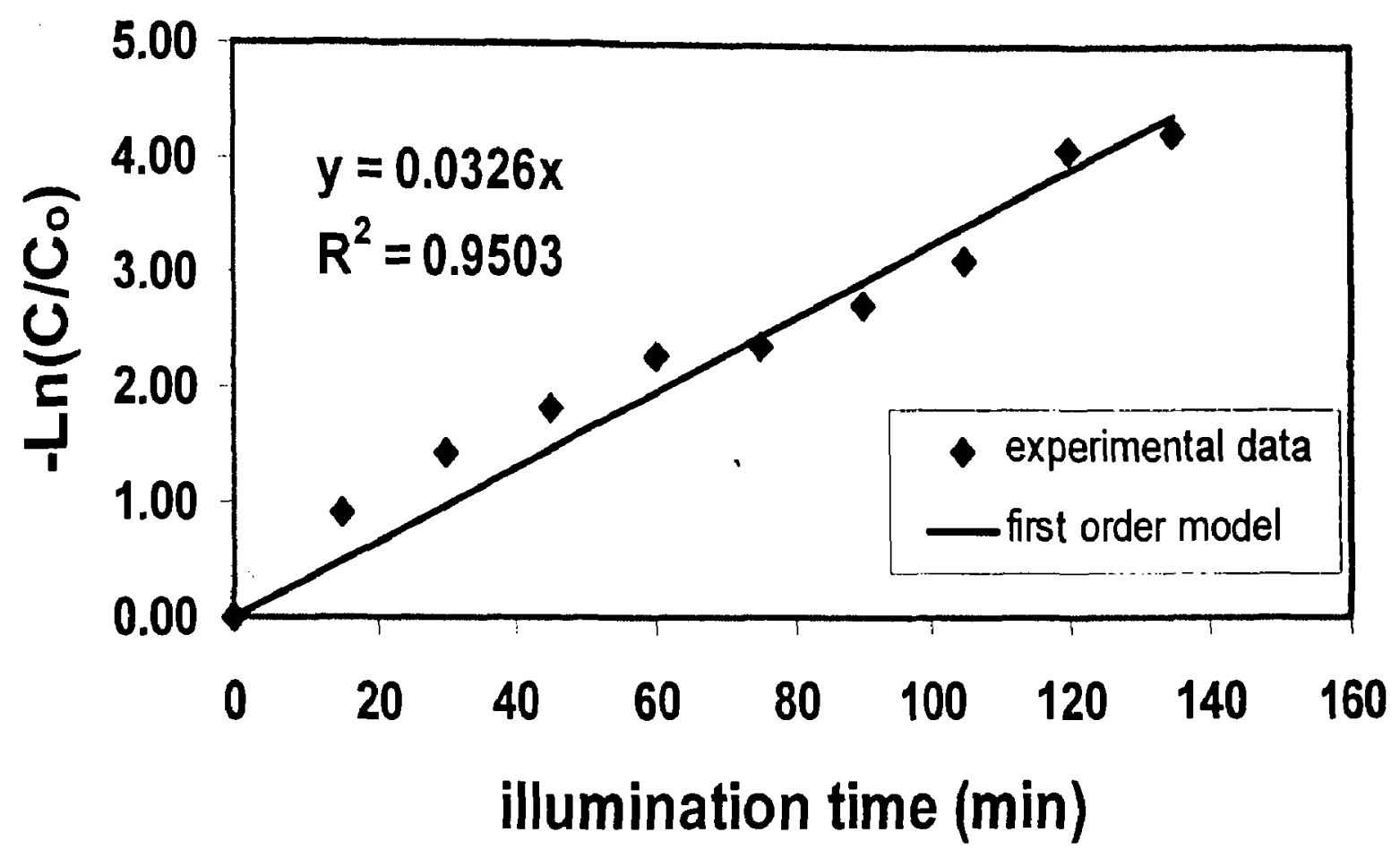

Figure 4.9: Comparison between the experimental data and simulated model for photolytic degradation of LAS with optimum concentration of $\mathrm{H}_{2} \mathrm{O}_{2}$. Initial concentration of LAS was $100 \mathrm{mg} / \mathrm{L}$ and flow rate $=12 \mathrm{LPM}$, mixing speed $=183 \mathrm{rpm}$. 


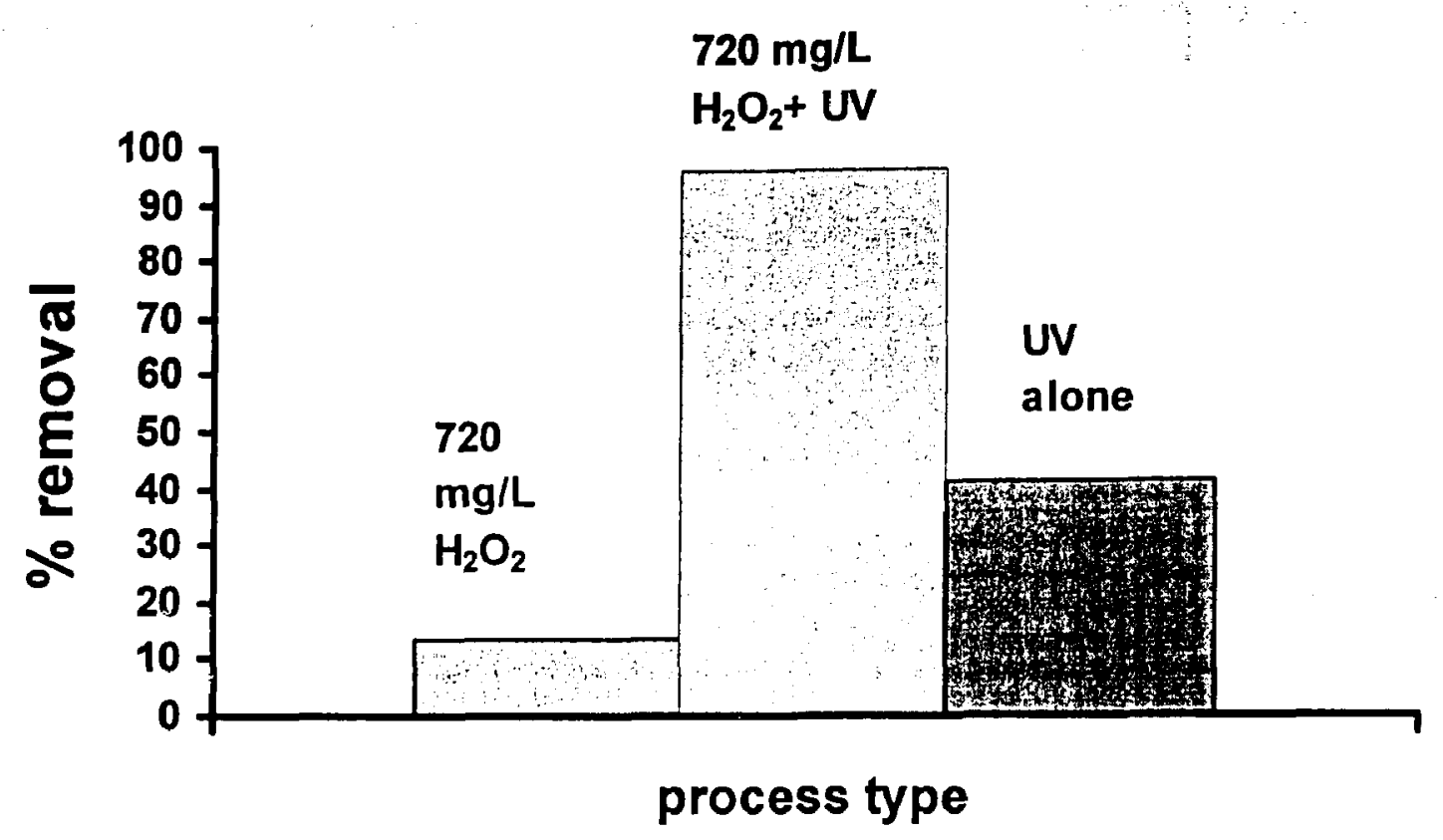

Figure 4.10: Comparison of the degradation for three different situations:

1. The optimum concentration of $\mathrm{H}_{2} \mathrm{O}_{2}$ with UV-254,

2. The optimum concentration of $720 \mathrm{mg} / \mathrm{L} \mathrm{H}_{2} \mathrm{O}_{2}$,

3. UV-254 alone.

Initial concentration of LAS was $100 \mathrm{mg} / \mathrm{L}$ and the illumination time was $120 \mathrm{~min}$. Flow rate and mixing speed are the same in all cases (flow rate $=12 \mathrm{LPM}$, mixing speed $=183$ rpm). 
Stabilization period

(lights off)

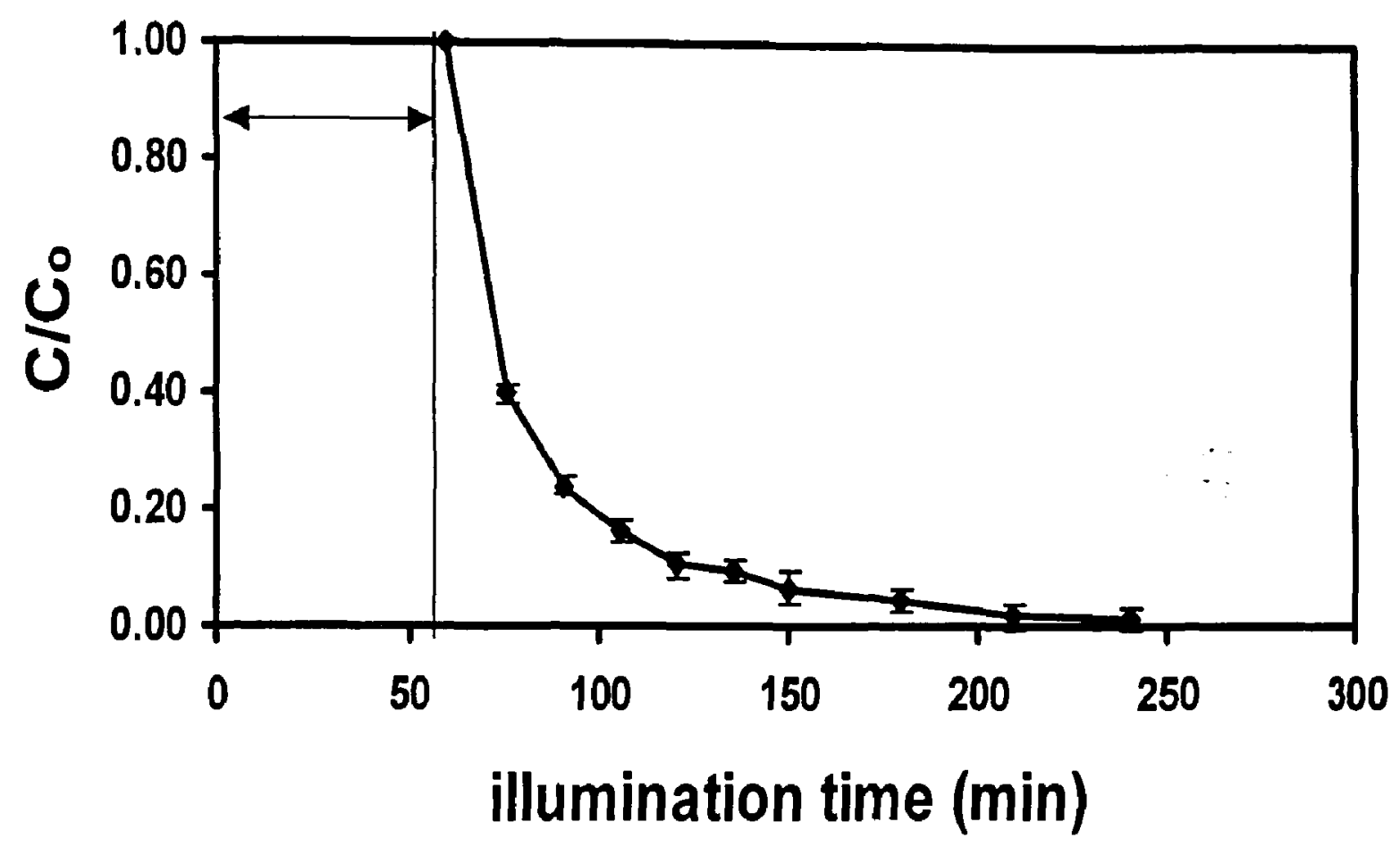

Figure 4.11: The necessary time for the complete photolytic degradation of LAS using optimum concentration of $\mathrm{H}_{2} \mathrm{O}_{2}(720 \mathrm{mg} / \mathrm{L})$. Initial concentration of LAS was $100 \mathrm{mg} / \mathrm{L}$, and flow rate $=12 \mathrm{LPM}$, mixing speed $=183 \mathrm{rpm}$. Three separate samples were taken and analyzed, in which case the standard deviations (error bars) represent sampling, preparation, and instrument error. 
As it is shown in Figure 4.12, the pH was decreased $2 \%$ and $20 \%$ in the treatment of LAS by UV and $\mathrm{UV} / \mathrm{H}_{2} \mathrm{O}_{2}$, respectively. This suggests that the photolytic degradation of LAS by $\mathrm{UV} / \mathrm{H}_{2} \mathrm{O}_{2}$ occurs through formation of acids. Decreasing the $\mathrm{pH}$ shows that the degradation follows the general degradation pattern for AOPs (production of acids)(Mantazavinos et al, 2000). Nevertheless, as the foaming ability of LAS was decreased by preceding the experiment, it was suggested that there are two mechanisms for degrading LAS (Mantzavinos et al. 2000):

1. Breakage of alkyl chain, which results a shorter chain incapable of behaving as detergent,

2. Attack of free radicals to the aromatic ring and removal of solfoxy group, which destroy the detergency nature.

\subsubsection{Impact of the Catalase on Analysis of $\mathrm{H}_{2} \mathrm{O}_{2}$}

To investigate the impact of the addition of insufficient or excessive amount of catalase on the analysis of $\mathrm{H}_{2} \mathrm{O}_{2}$ and $\mathrm{BOD}_{5}$ test, different concentrations of catalase were examined. To decompose $60 \mathrm{mg} / \mathrm{L}$ of $\mathrm{H}_{2} \mathrm{O}_{2}, 0.1 \mathrm{mg}$ of catalase was added to $100 \mathrm{~mL}$ of sample and left without stirring for $100 \mathrm{~min}$ (Ito et al., 1998). After that time, the concentration of $\mathrm{H}_{2} \mathrm{O}_{2}$ was measured by DPD method and it was observed that its concentration was zero. Insufficient and excessive amount of catalase were added to 6 samples of $\mathrm{H}_{2} \mathrm{O}_{2}$ with the volume of $100 \mathrm{~mL}$ each. Sodium acetate was chosen as a standard to compare the impact of catalase on the chosen test. Also, the presence of $\mathrm{H}_{2} \mathrm{O}_{2}$ can interfere with BOD test and inhibit the growth of microorganisms. Therefore, $\mathrm{BOD}_{5}$ test was chosen as a reference test. Six different samples containing different concentrations of catalase were prepared. Samples $1-5$ contained $0,0.05,0.1,0.5$, and 1 $\mathrm{mg}$ of catalase, respectively. The mentioned masses of catalase were dissolved in $100 \mathrm{~mL}$ of $\mathrm{H}_{2} \mathrm{O}_{2}$ solution with initial concentration of $\mathrm{H}_{2} \mathrm{O}_{2}$ equal to $60 \mathrm{mg} / \mathrm{L}$.

Sample 6 was $1 \mathrm{mg}$ catalase with no $\mathrm{H}_{2} \mathrm{O}_{2}$ in it, and sample 7 was just sodium acetate with the concentration of $30 \mathrm{mg} / \mathrm{L}$. Thirty $\mathrm{mL}$ of sodium acetate was added to 7 BOD bottles, and $25 \mathrm{~mL}$ of samples 1-6 were added to just 6 of those bottles. 


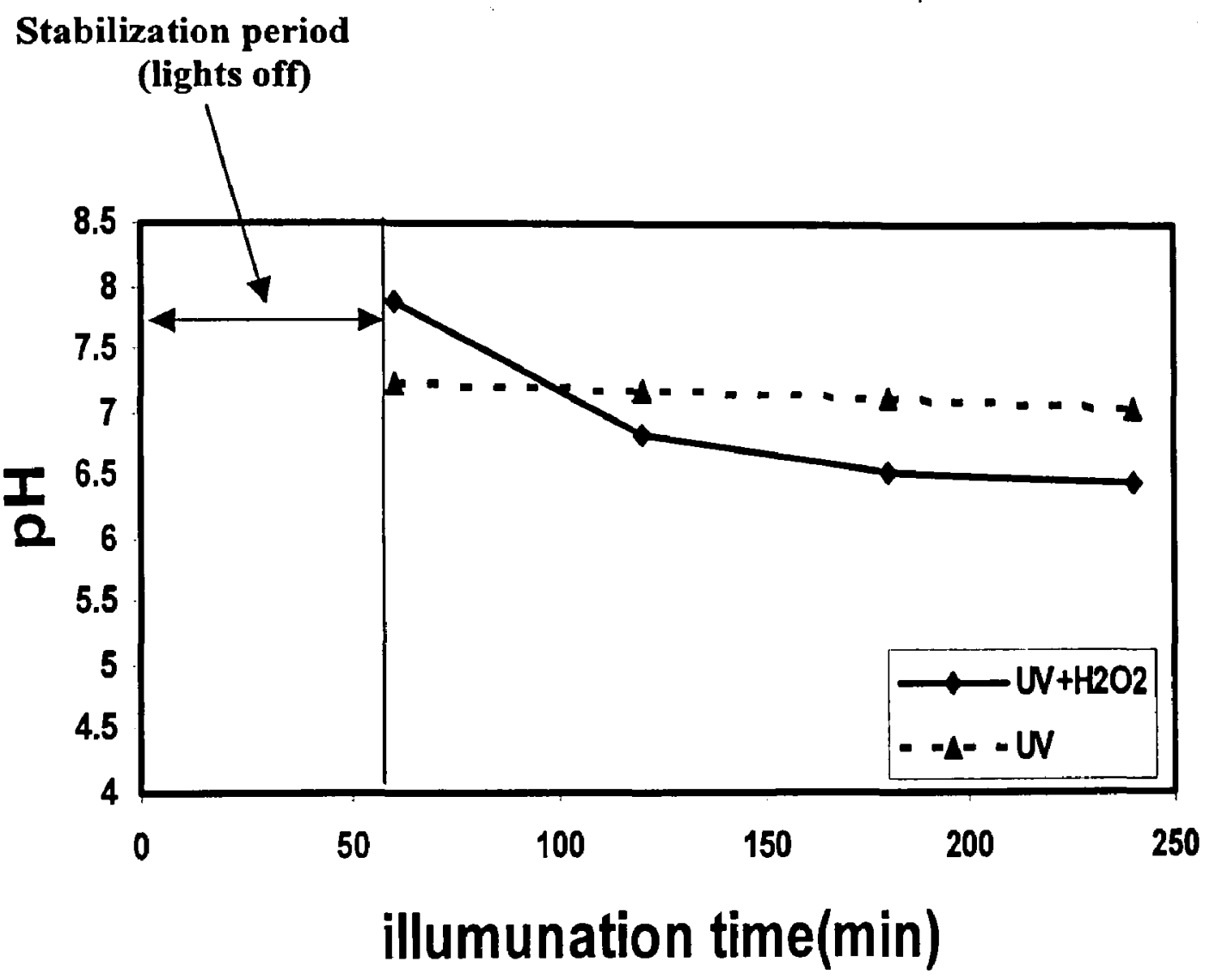

Figure 4.12: Comparison between the changes in $\mathrm{pH}$ with $\mathrm{UV}_{254}$ and $\mathrm{UV}+\mathrm{H}_{2} \mathrm{O}_{2}$, Mixing=183 rpm, flow rare $=12 \mathrm{~L} / \mathrm{min}, \mathrm{C}_{\mathrm{o}}=100 \mathrm{mg} / \mathrm{L}$. 
The rest of the bottles were filled with appropriate amount of seed solution and diluted water (Section 3.2.16). The sealed bottles were kept in incubator at $20^{\circ} \mathrm{C}$ for 5 days. The results are illustrated in Figure 4.13. It was expected that if the $\mathrm{H}_{2} \mathrm{O}_{2}$ was reduced by proper amount of catalase, the $\mathrm{BOD}_{5}$ of the solutions be around the $\mathrm{BOD}_{5}$ of sodium acetate solution alone. As Figure 4.13 depicts, it can be concluded that when the concentration of catalase is lower than optimum, there are still some $\mathrm{H}_{2} \mathrm{O}_{2}$ presence in solution. Therefore, residual $\mathrm{H}_{2} \mathrm{O}_{2}$ produce a toxic effect and reduce the consumption of oxygen, and $\mathrm{BOD}_{5}$ cannot reach to its true value which is equal to the $\mathrm{BOD}_{5}$ of sodium acetate alone. Moreover, excessive amount of catalase can increase the consumption of oxygen in the test. Moreover, excess am f catalase produced the initial dissolved oxygen in the solution above the saturation level $(13 \mathrm{mg} / \mathrm{L} \mathrm{O} 2)$, this dissolved oxygen would decrease dramatically after 5 days of incubation. Therefore, the concentration of catalase should be around its optimum value, which is $0.1 \mathrm{mg}$ of catalase per $100 \mathrm{~mL}$ of sample containing $\mathrm{H}_{2} \mathrm{O}_{2}$ at $60 \mathrm{mg} / \mathrm{L}$, to eliminate $60 \mathrm{mg} / \mathrm{L}$ of $\mathrm{H}_{2} \mathrm{O}_{2}$ effectively.

\subsubsection{Impact of $\mathrm{H}_{2} \mathrm{O}_{2}$ on $\mathrm{COD}$ and $\mathrm{BOD}$ test}

To investigate the impact of $\mathrm{H}_{2} \mathrm{O}_{2}$ presence on the COD tests, the COD of the samples with $\mathrm{H}_{2} \mathrm{O}_{2}$ were compared to the same samples where their $\mathrm{H}_{2} \mathrm{O}_{2}$ had been eliminated. It was observed that the samples with $\mathrm{H}_{2} \mathrm{O}_{2}$ exert an excessive amount of oxygen for chemical oxidation in comparison to the samples without $\mathrm{H}_{2} \mathrm{O}_{2}$. Meanwhile, the theoretical oxygen demand of the $100 \mathrm{mg} / \mathrm{L}$ of LAS was calculated as $240 \mathrm{mg} / \mathrm{L} \mathrm{O}$. It is known that COD is usually lower than the theoretical oxygen demand as most of the organic compounds (mainly aromatic) cannot be oxidized chemically under test conditions. Therefore, the COD test was conducted on the LAS samples treated by $\mathrm{UV} / \mathrm{H}_{2} \mathrm{O}_{2}$ for 90 minutes. As these samples contained residual $\mathrm{H}_{2} \mathrm{O}_{2}$, the COD of these samples were analyzed with residual $\mathrm{H}_{2} \mathrm{O}_{2}$, and it was compared to the COD of these samples after elimination of $\mathrm{H}_{2} \mathrm{O}_{2}$.

The COD for the sample with residual $\mathrm{H}_{2} \mathrm{O}_{2}$, which is higher than ThOD, cannot be the true value for $\mathrm{COD}$ (Figure 4.14) as the theoretical value of oxygen consumption is the maximum amount oxygen that a compound can consume during its chemical oxidation. 


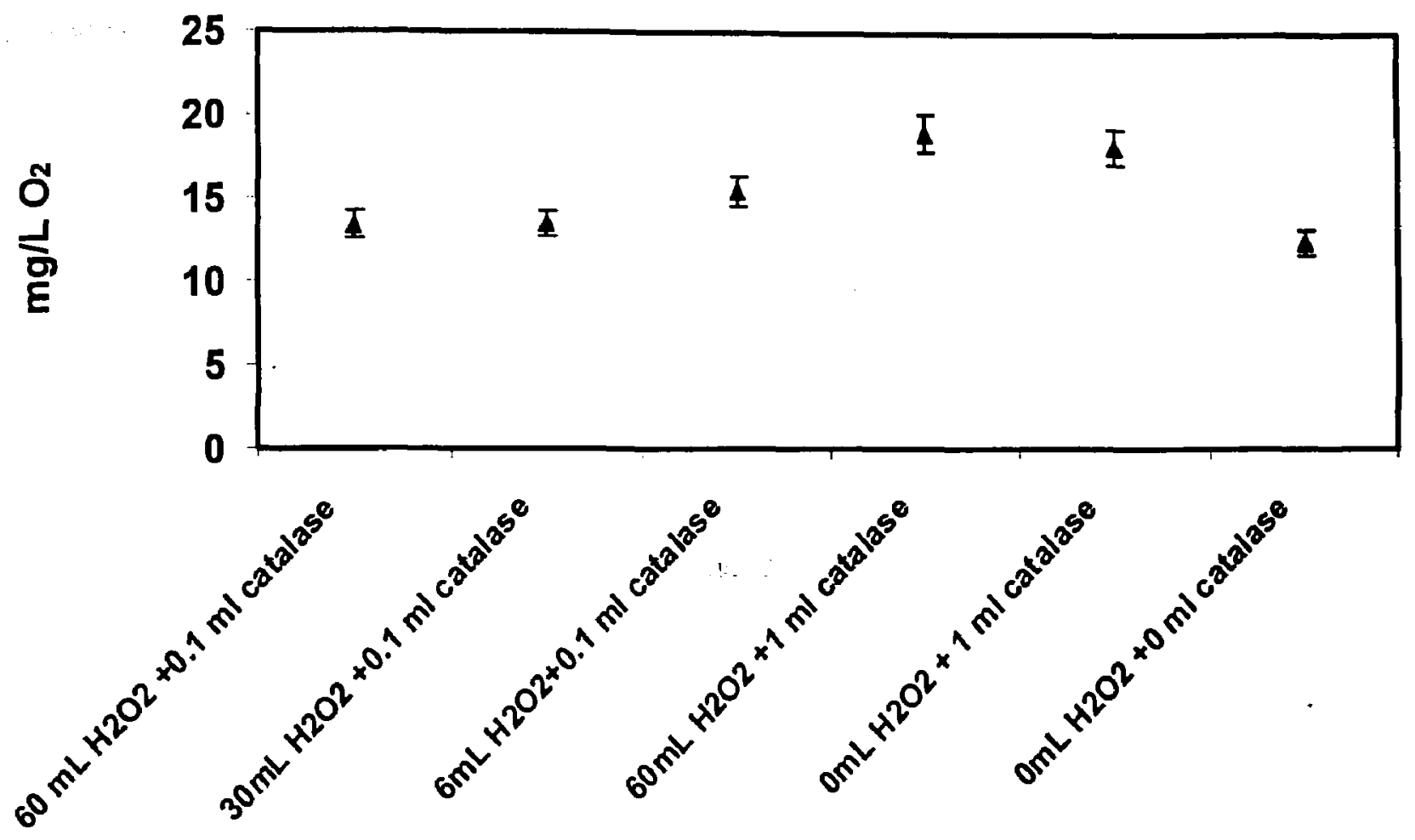

Figure 4.13: The impact of the addition of insufficient or excessive amount of catalase on $\mathrm{BOD}_{5}$ test for different concentrations of catalase.

The error bars represent the standard deviation of three replicate aliquots of a single sample, in which case the standard deviation represents preparation and instrument error. 
Therefore, the residual $\mathrm{H}_{2} \mathrm{O}_{2}$ can interfere with $\mathrm{COD}$ measurements due to its reaction with dichromate, and this reaction could increase the measured COD (Lin et al., 1999). Moreover as it can be observed from Figure 4.13, the sample with residual $\mathrm{H}_{2} \mathrm{O}_{2}$ consumes less oxygen in $\mathrm{BOD}_{5}$ test, compared to the sample with no $\mathrm{H}_{2} \mathrm{O}_{2}$. This is due to the fact that $\mathrm{H}_{2} \mathrm{O}_{2}$ is bactericide and inhibits the bacteria activity. Therefore, residual $\mathrm{H}_{2} \mathrm{O}_{2}$ can inhibit the bacterial growth in the BOD tests, and hence, underestimate the actual BOD.

\subsubsection{Consumption of $\mathrm{H}_{2} \mathrm{O}_{2}$ during the Photolytic Reaction of LAS}

During the photo-oxidation process, the LAS concentration was decreased. In the photolytic oxidation using UV along with $\mathrm{H}_{2} \mathrm{O}_{2}$ the degradation rate of LAS was higher than the degradation rate of LAS by UV alone by about $50 \%$ in 90 minutes. Consequently, there was a decrease in the concentration of $\mathrm{H}_{2} \mathrm{O}_{2}$ as it was being used as an oxidant.

The consumption of $\mathrm{H}_{2} \mathrm{O}_{2}$ was monitored from the beginning of the experiment until the concentration of LAS became about zero. The concentration of $\mathrm{H}_{2} \mathrm{O}_{2}$ was measured by DMP method, a precise technique. Figure 4.15 shows the consumption of $\mathrm{H}_{2} \mathrm{O}_{2}$ during three hours of reaction. The decrease in the concentration of $\mathrm{H}_{2} \mathrm{O}_{2}$ was due to the production of hydroxyl radicals and reaction between hydroxyl radical and organics as follows:

$\mathrm{H}_{2} \mathrm{O}_{2}+\mathrm{UV} \rightarrow 2^{\circ} \mathrm{OH}$

$\cdot \mathrm{OH}+$ organics $\rightarrow$ intermediate $\rightarrow \mathrm{CO}_{2}+\mathrm{H}_{2} \mathrm{O}$

Intermediates also react with ${ }^{\circ} \mathrm{OH}$.

The $\mathrm{H}_{2} \mathrm{O}_{2}$ decrease during this period of time was uniform, and hence, it was observed that its consumption rate followed zero-order model (Figure 4.15). 


\section{Stabilization period}

(lights off)

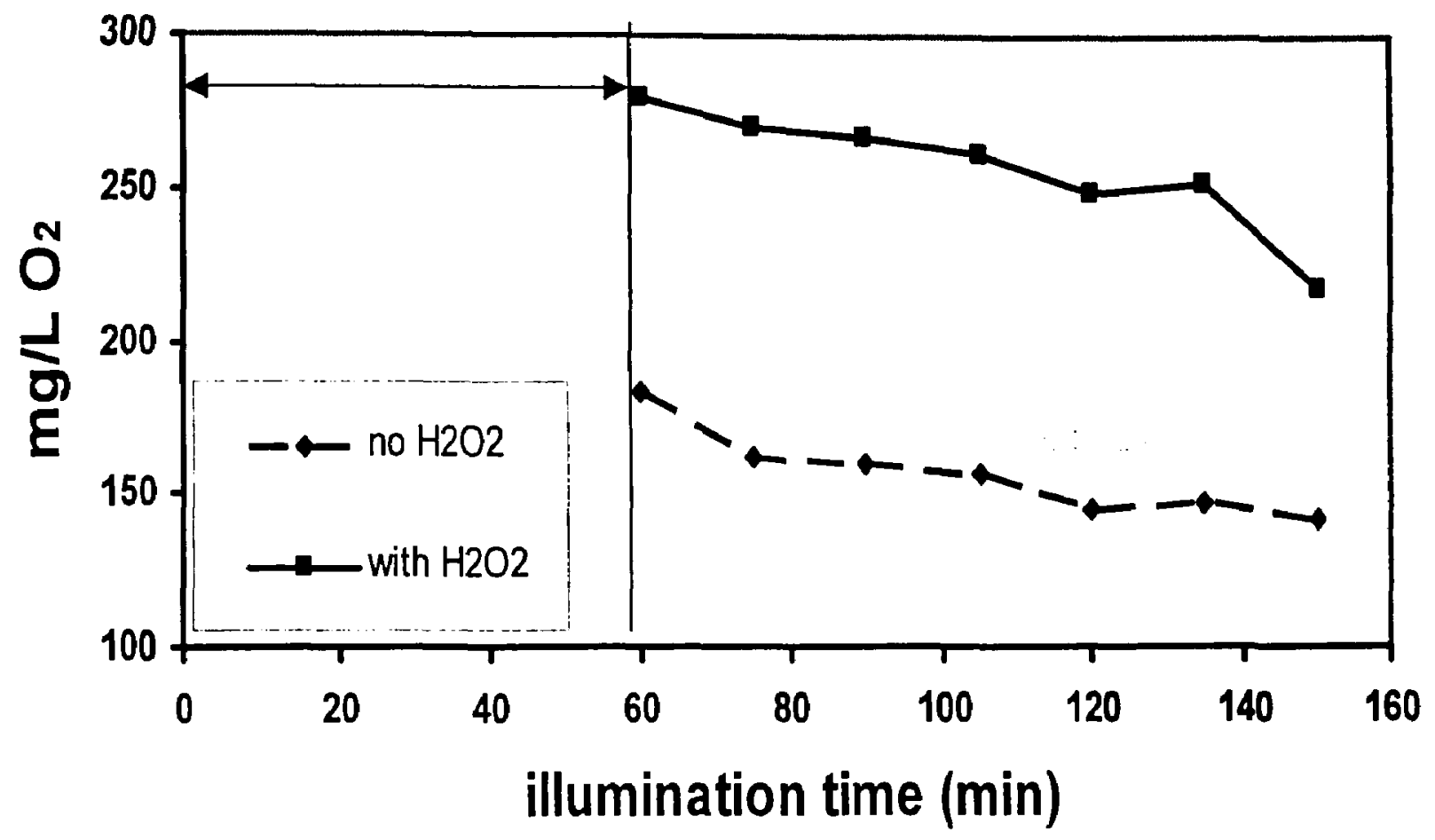

Figure 4.14: Changes in COD during the photolytic degradation of LAS in the presence of $\mathrm{H}_{2} \mathrm{O}_{2}$, and after removal of $\mathrm{H}_{2} \mathrm{O}_{2}$ by catalase. Comparison between ThOD and the effect of $\mathrm{H}_{2} \mathrm{O}_{2}$ on increasing the COD value. Initial ThOD was $240 \mathrm{mg} / \mathrm{L} \mathrm{O}_{2}$.

Illumination time means that the changes in the value of COD were monitored during the photolytic degradation $\left(\mathrm{UV}+\mathrm{H}_{2} \mathrm{O}_{2}\right)$ of LAS. 
The $\mathrm{H}_{2} \mathrm{O}_{2}$ consumption model is as follows:

$$
\left[\mathrm{H}_{2} \mathrm{O}_{2}\right]=-3.5786 \mathrm{t}+691.12
$$

where $\left[\mathrm{H}_{2} \mathrm{O}_{2}\right]$ is the concentration of $\mathrm{H}_{2} \mathrm{O}_{2}$ at time $t$ and rate constant is equal to 3.57 $\min ^{-1}$. Therefore, the approximate concentration of $\mathrm{H}_{2} \mathrm{O}_{2}$ can be calculated at each time according to the Equation 4.7, to find the optimum concentration of catalase which is necessary to eliminate the residual $\mathrm{H}_{2} \mathrm{O}_{2}$ for the subsequent biological treatment (Appendix A).

\subsection{Effects of Photolytic Pre-treatment on the Biodegradability of LAS}

\subsubsection{Biological Oxygen Demand for LAS}

It has been shown that the inhibitory effect of LAS in its biodegradability increases by increasing the concentration of LAS (Patterson et al., 2002). The biodegradability of four different concentrations of untreated LAS was examined (100 $\mathrm{mg} / \mathrm{L}, 50 \mathrm{mg} / \mathrm{L}, 25 \mathrm{mg} / \mathrm{L}$, and $12 \mathrm{mg} / \mathrm{L}$ ). The $\mathrm{BOD}_{5}$ tests for all concentrations were performed. As Figure 4.16 shows, by increasing the concentration of LAS the consumption of $\mathrm{O}_{2}$ was decreased. The consumption of oxygen was decreased by about $50 \%$, by changing the concentration of LAS from $25 \mathrm{mg} / \mathrm{L}$ to $100 \mathrm{mg} / \mathrm{L}$. It is obvious that this decrease was not due to the decrease of organics in bottles; however, the microorganisms in the activated sludge could not grow and use oxygen by increasing the LAS concentration. Therefore, LAS has inhibitory effect on microorganisms as its concentration increases. Moreover, the ratio of $\mathrm{BOD}_{5} / \mathrm{COD}$ is often used to express the biodegradability of wastewater. Figure 4.17 shows the ratio of $\mathrm{BOD}_{5} / \mathrm{COD}$ for the same concentrations of LAS. Values for $\mathrm{BOD}_{5} / \mathrm{COD}$ less than 0.4 suggest that the wastewater is difficult to be biodegraded. It can be observed that this ratio for LAS at $100 \mathrm{mg} / \mathrm{L}$ is about 0.1 , suggesting that LAS is recalcitrant at higher concentrations, and it is resistant to conventional biological treatments (Yu et al., 1998). 


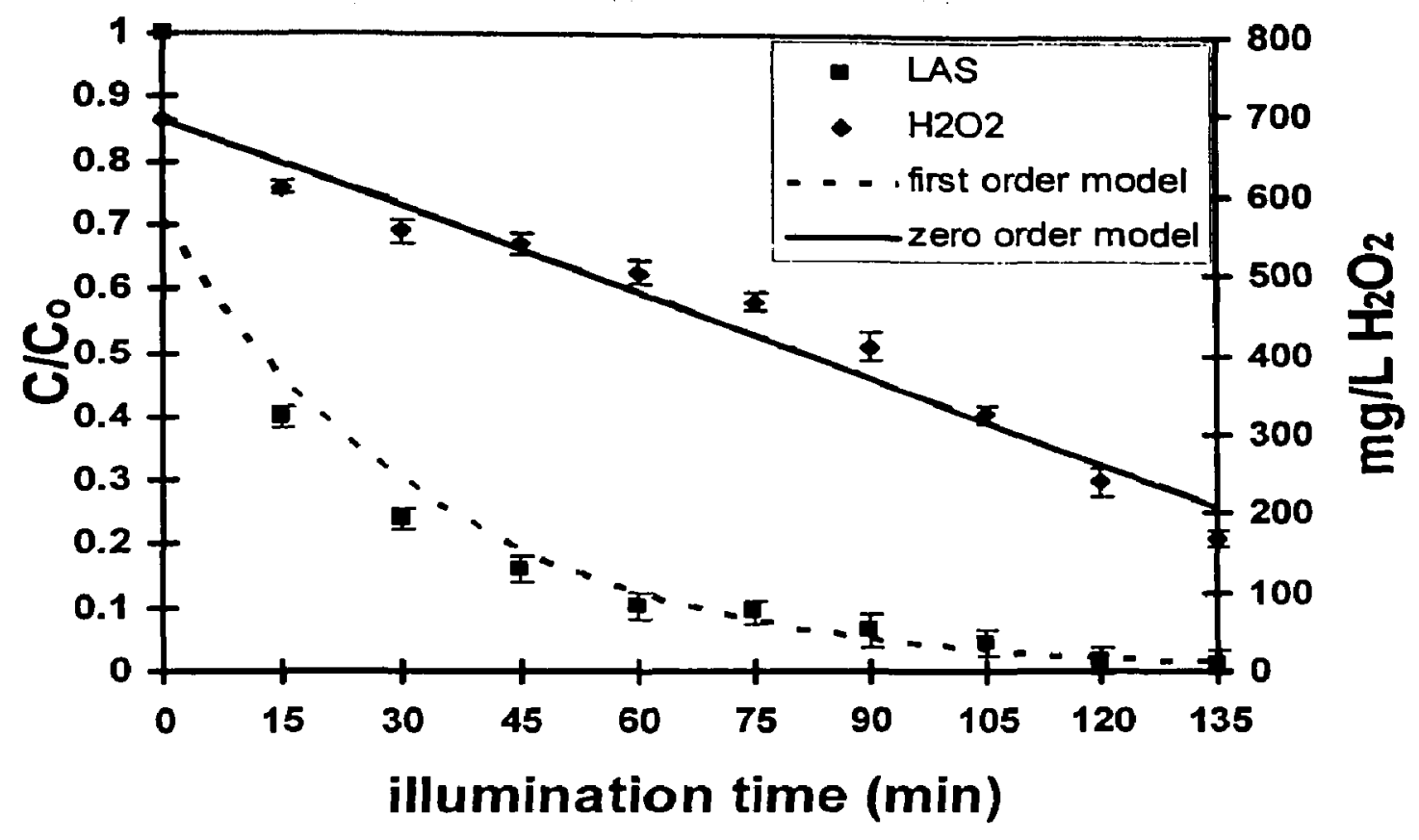

Figure 4.15: Consumption of $\mathrm{H}_{2} \mathrm{O}_{2}$ during the photolytic reaction of LAS using optimum concentration of $\mathrm{H}_{2} \mathrm{O}_{2}$ in cylindrical photoreactor, mixing $=183 \mathrm{rpm}$, flow rate $=12 \mathrm{~L} / \mathrm{min}$, $\mathrm{C}_{\text {oLAS }}=100 \mathrm{mg} / \mathrm{L}$.

Three separate samples were taken and analyzed, in which case the standard deviations (error bars) represent sampling, preparation, and instrument error. 
These results were in accordance with another study that the growth rate of mixed culture of microorganisms can be inhibited by LAS at the concentration of $95 \mathrm{mg} / \mathrm{L}$ (WHO, 1996).

The effects of photolytic pre-treatment of LAS on its biodegradability during the course of the reaction were studied. As Figure 4.18 depicts, the ratio of $\mathrm{C} / \mathrm{C}_{\mathrm{o}}$ (concentration of LAS at any time/initial concentration of LAS) was decreased up to $92 \%$ during 90 minutes of photolytic reaction using $720 \mathrm{mg} / \mathrm{L}$ of $\mathrm{H}_{2} \mathrm{O}_{2}$ as an oxidant. However, this decrease was sharp during the initial period of the reaction. After 15 minutes, $C / C_{0}$ decreases gradually. The opposite trend was observed for the ratio of $\mathrm{BOD}_{5} / \mathrm{COD}$. This ratio increases gradually. This suggests that as the concentration of LAS decreases, the intermediates produced are more biodegradable than the parent compounds. After 90 minutes, the $\mathrm{BOD}_{5} / \mathrm{COD}$ was 0.4 , suggesting that although the untreated LAS was recalcitrant, the intermediates produced at this point were biodegradable under conventional biological treatment.

Relative changes in the biodegradability of wastewater samples during photochemical oxidation time can also be expressed in terms of biodegradability factor, $\mathrm{f}_{\mathrm{B}}$ (Equation 2.16). It was observed that the biodegradability factor for the LAS treated in photolytic reactor was increased as the time proceeded (Figure 4.19). Therefore, again it was concluded that pre-treatment of LAS by this method was toward the increasing of its biodegradability. However, this increase was sharp during the first hour and after that increases gradually. It is in accordance with the $\mathrm{BOD}_{5} / \mathrm{COD}$ ratio, as this ratio follows the same increasing pattern. On the other hand, comparing this finding with the changes in the concentration of LAS during illumination period, it could also be concluded that LAS decreased very fast during the first hour and after that there was little change in its concentration. To measure the biodegradability of the LAS, residual $\mathrm{H}_{2} \mathrm{O}_{2}$ was eliminated, as it could inhibit the growth of microorganisms. This elimination was done by catalase using the technique explained before. 


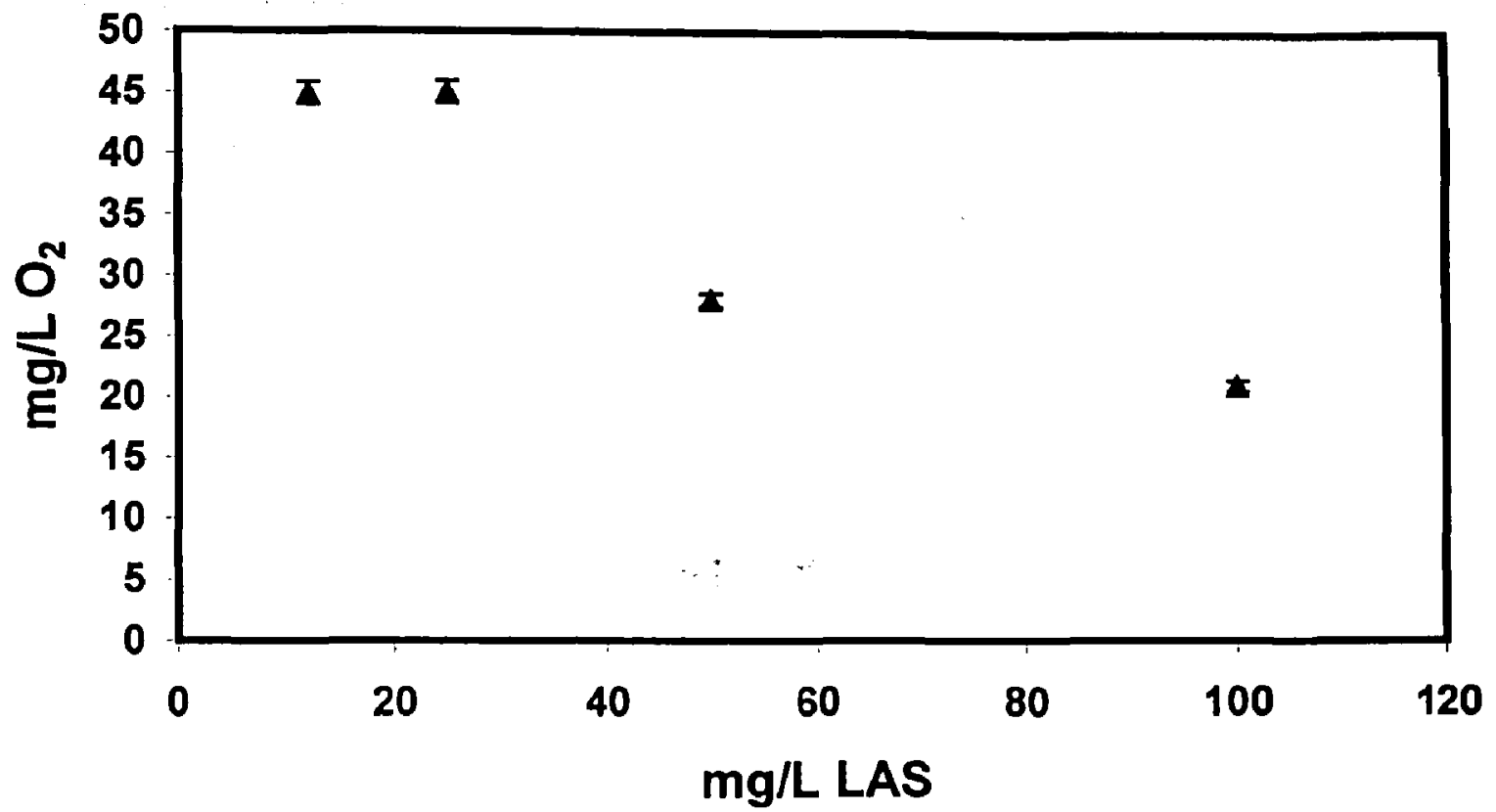

Figure 4.16: $\mathrm{BOD}_{5}$ test results for 4 different concentrations of untreated LAS.

The error bars represent the standard deviation of three replicate aliquots of a single sample, in which case the standard deviation represents preparation and instrument error. 


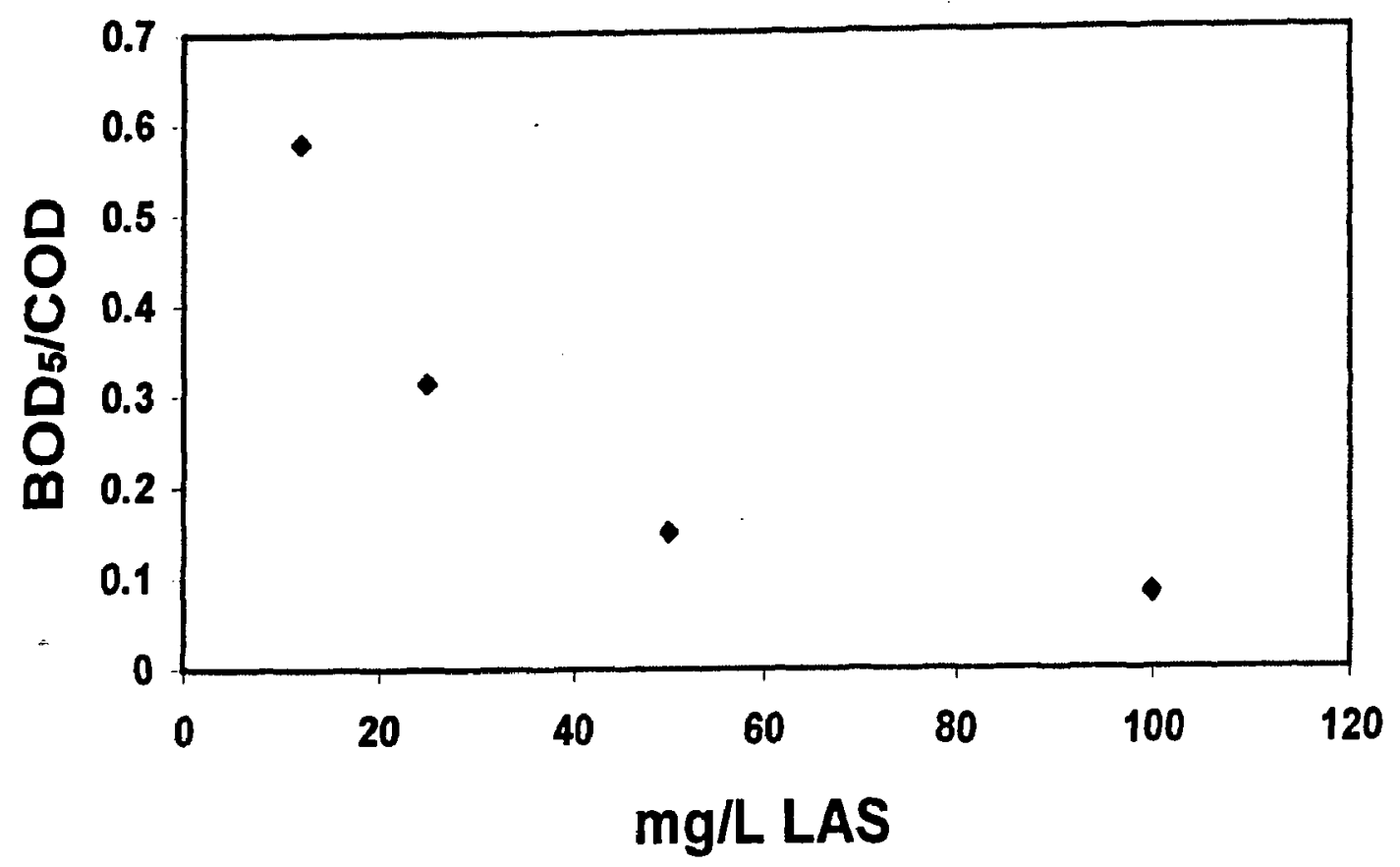

Figure 4.17: Ratio of BOD5/COD for 4 different concentrations of untreated LAS. 


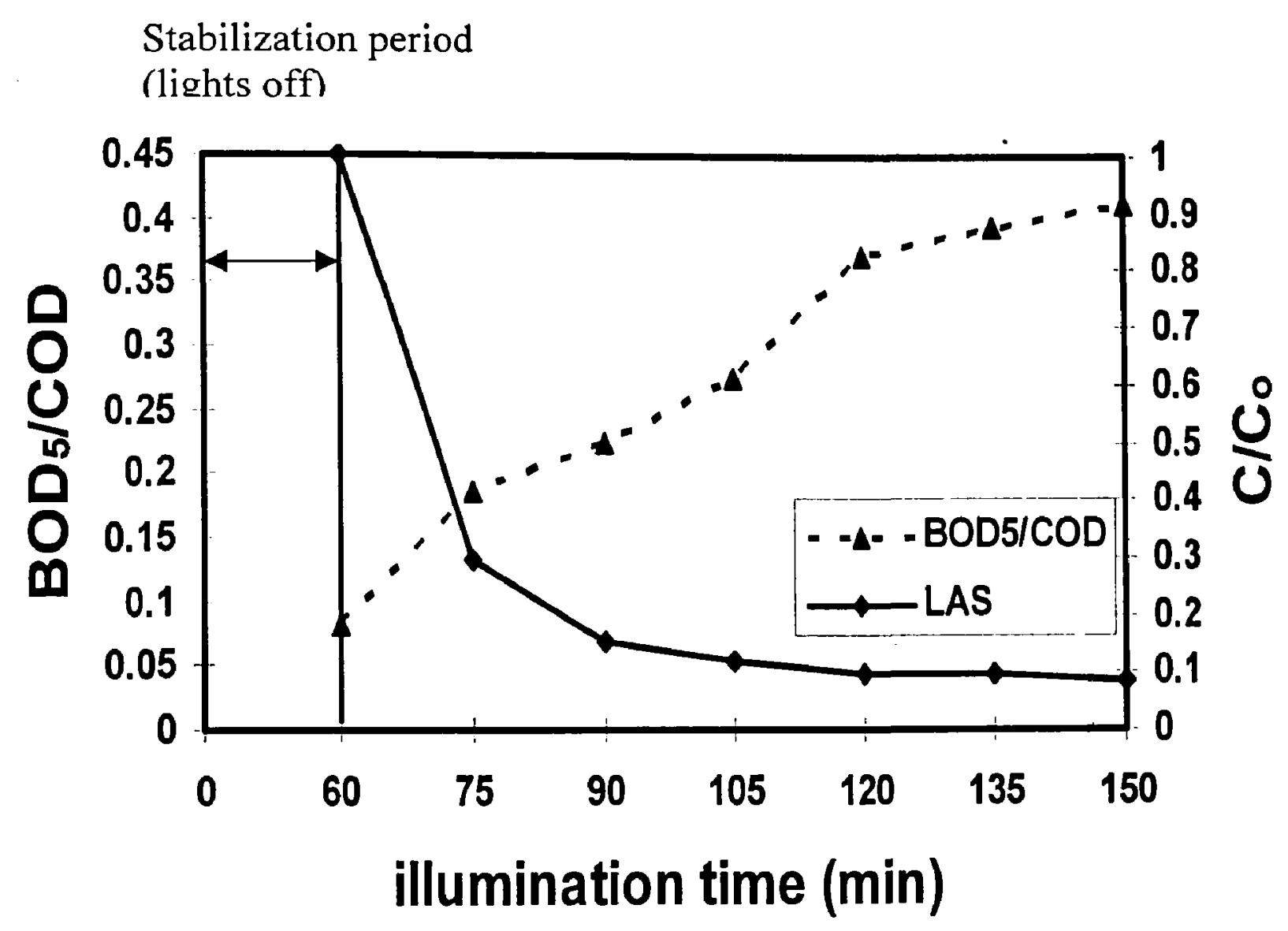

Figure 4.18: Effects of photolytic pre-treatment of LAS using $720 \mathrm{mg} / \mathrm{L}$ of $\mathrm{H}_{2} \mathrm{O}_{2}$ as an oxidant on its biodegradability. Flow rate $=8 \mathrm{LPM}$, Mixing speed $=183 \mathrm{rpm}, \mathrm{C}_{\mathrm{LAS}}=100$ $\mathrm{mg} / \mathrm{L}$. 


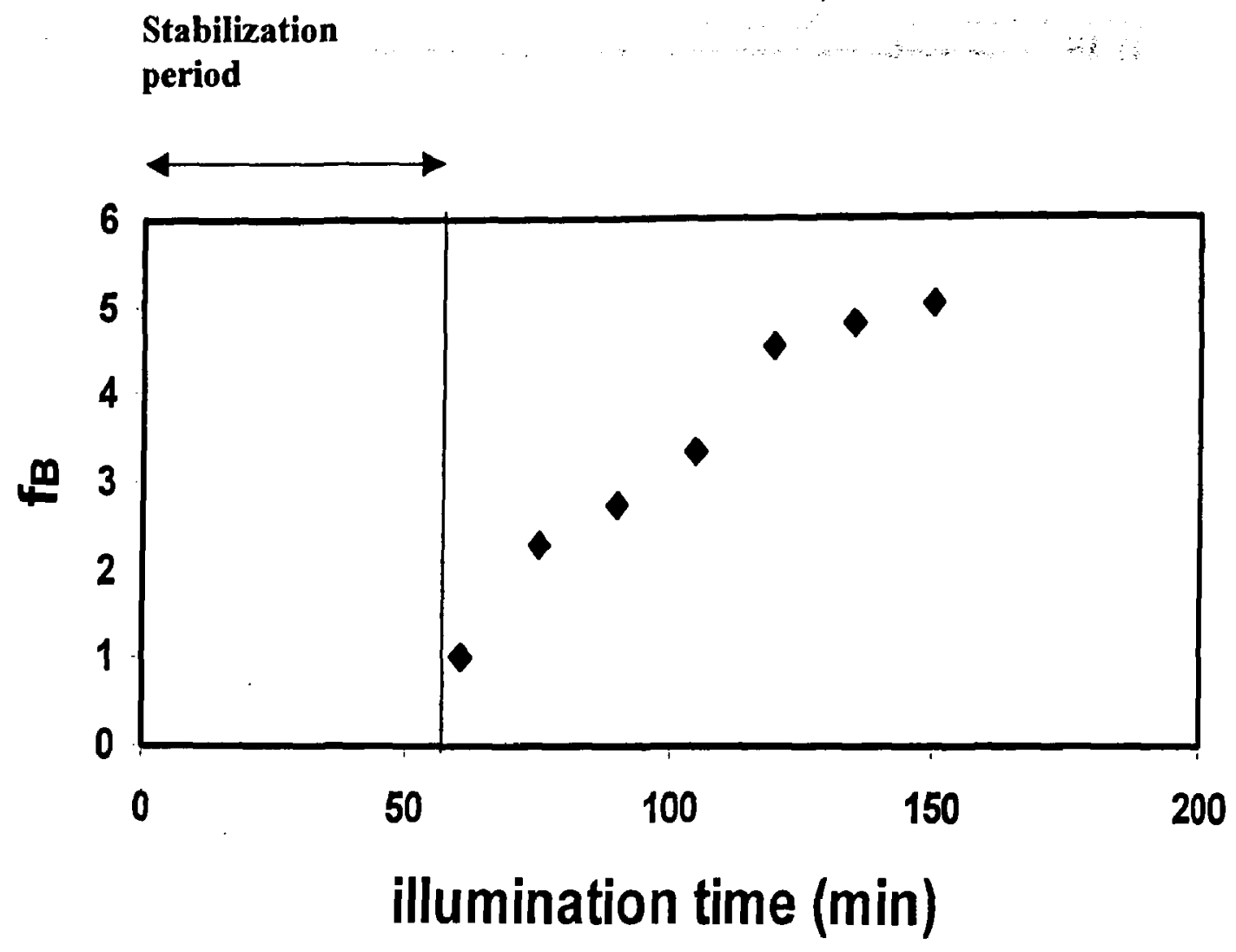

Figure 4.19: Increasing the biodegradability factor of LAS by proceeding the reaction, LAS was treated in photolytic reactor using $\mathrm{H}_{2} \mathrm{O}_{2}(720 \mathrm{mg} / \mathrm{L})$ as an oxidant.

$f_{B}=\frac{B O D_{s, t}\left(C O D_{t}\right)^{-1}}{B O D_{5,0}\left(C O D_{0}\right)^{-1}}$ 


\subsubsection{Ultimate BOD for the Biodegradation of LAS}

The BOD for three different samples of LAS was modeled as follows:

1. Untreated LAS at the concentration of $100 \mathrm{mg} / \mathrm{L}$

2. Pre-treated LAS by UV and optimum concentration of $\mathrm{H}_{2} \mathrm{O}_{2}$ after 15 minutes of treatment

3. Pre-treated LAS by UV and optimum concentration of $\mathrm{H}_{2} \mathrm{O}_{2}$ after 1.5 hours of treatment.

The BOD model is as follows (Section 3.2.17):

$B O D,=U B O D\left(1-e^{-k t}\right)$

where $\mathrm{BOD}_{\mathrm{t}}, \mathrm{k}, \mathrm{t}$, and $\mathrm{UBOD}$ are the amount of $\mathrm{BOD}$ at time $\mathrm{t}$, rate constant, reaction time, and is the ultimate biological oxygen demand, respectively.

Figure 4.20 illustrates the BOD results for those three samples, mentioned above, in a 30-day period. With high concentration of LAS in the untreated sample, oxygen consumption was only $5.2 \mathrm{mg} / \mathrm{L} \mathrm{O}_{2}$ during 30 days, indicating that LAS was toxic to the microorganisms. Therefore, complete mineralization of LAS at the concentration of 100 $\mathrm{mg} / \mathrm{L}$ was not possible. The consumption of oxygen during 30 days for the second sample was eight times more than first sample (second sample consumed $38 \mathrm{mg} / \mathrm{L} \mathrm{O}$ during 30 days), but still less than the third sample. The consumption of oxygen during 30 days for the third sample was $57 \mathrm{mg} / \mathrm{L} \mathrm{O}_{2}$. This indicates that the second sample was more biodegradable than the first sample. Therefore, the pre-treatment had the ability to increase the biodegradability of LAS, and as the reaction progress this effect was increased. Plotting the BOD versus time for those samples indicates that the removal of LAS in those samples follow first order model (Equation 4.8). Table 4.1 shows BOD models for each sample. As it can be seen the sample with $1.5 \mathrm{~h}$ of photolytic pretreatment has the fastest reaction rate which is equal to 0.2839 (day) ${ }^{-1}$. Therefore, it would be biodegraded 2 times faster than the untreated sample at $100 \mathrm{mg} / \mathrm{L}$ of LAS. 
It is documented that the ultimate BOD of a sample is equal to 0.92 times the biodegradable portion of its COD (Eckenfelder, 2000). Therefore, the relation between UBOD and biodegradable COD is as follows:

$$
\mathrm{UBOD}=0.92 \times(\mathrm{COD})_{\mathrm{d}}
$$

where UBOD and (COD) $d$ are ultimate BOD and biodegradable portion of total COD of the sample, respectively. Moreover, total soluble COD can be calculated as the sum of biodegradable COD and non-biodegradable COD. Therefore, the portion of nonbiodegradable COD for the samples can be calculated easily. It was observed that as the photolytic reaction of LAS proceeded, the portion of non-biodegradable COD was decreased. As the non-biodegradable COD for the sample after 1.5 hours of photolytic treatment with $\mathrm{H}_{2} \mathrm{O}_{2}$ was $55 \%$ of total COD while this value for untreated LAS was $93 \%$. Consequently, half of the total $\mathrm{COD}$ in the sample with $1.5 \mathrm{~h}$ pre-treatment was biodegradable, whereas almost all of the total COD in the untreated sample was nonbiodegradable COD. Therefore, if LAS with photolytic pre-treatment is going to be treated further by biological treatment, all of the organics cannot be removed in the biological treatment. That is due to the presence of some non-biodegradable intermediates in the effluent of photolytic treatment $(56 \%$ of intermediates were nonbiodegradable in the effluent of photolytic treatment after $1.5 \mathrm{~h}$ of pre-treatment). This portion of non-biodegradable COD can be corresponded to the primary photolytic degradation of LAS oxidizing alkyl chain, and resulting sulfophenyl(di)carboxylates. It has also been reported that sulfophenyl(di)carboxylates are refractory to biodegradation (Patterson et al., 2002). Consequently, as the photolytic reaction proceeded, the biodegradable portion of COD was produced through cleavage the phenyl ring and removing sulfonate group.

\subsubsection{Shake Flask Tests for Biodegradation of LAS}

The experiment was done according to the method described in Section 3.2.20. The LAS solutions used were: 


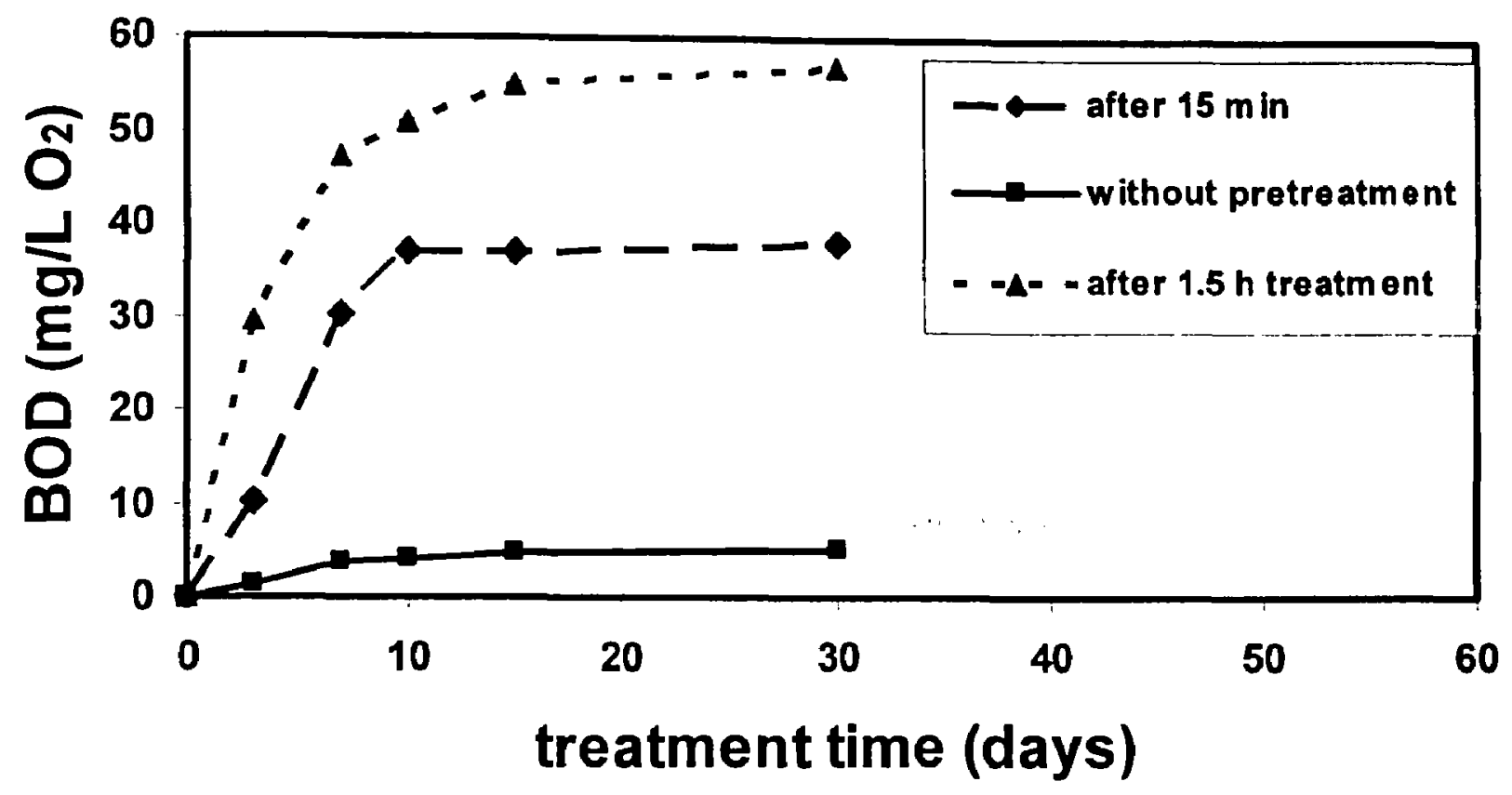

Figure 4.20: BOD tests for three samples in a 30-day treatment period for the following conditions

1. Untreated LAS at the concentration of $100 \mathrm{mg} / \mathrm{L}$,

2. Pre-treated LAS by UV-254 and optimum concentration of $\mathrm{H}_{2} \mathrm{O}_{2}(720 \mathrm{mg} / \mathrm{L})$ after 15 minutes of treatment,

3. Pre-treated LAS by UV-254 and optimum concentration of $\mathrm{H}_{2} \mathrm{O}_{2}(720 \mathrm{mg} / \mathrm{L})$ after 1.5 hours of treatment. 
Table 4.1: BOD models for three different samples.

1. Untreated LAS at the concentration of $100 \mathrm{mg} / \mathrm{L}$,

2. Pre-treated LAS by UV-254 and optimum concentration of $\mathrm{H}_{2} \mathrm{O}_{2}(720 \mathrm{mg} / \mathrm{L})$ after $15 \mathrm{~min}$. of treatment,

3. Pre-treated LAS by UV-254 and optimum concentration of $\mathrm{H}_{2} \mathrm{O}_{2}(720 \mathrm{mg} / \mathrm{L})$ after 1.5 hours of treatment.

The BOD model is: $B O D_{1}=U B O D\left(1-e^{-k t}\right), \mathrm{UBOD}, \mathrm{BOD}_{\mathrm{t}}$, and $\mathrm{k}$ are ultimate $\mathrm{BOD}$, BOD at time t, and rate constant, respectively.

\begin{tabular}{|l|c|c|}
\hline Process & UBOD $\left(\mathrm{mg} / \mathrm{L} \mathrm{O}_{2}\right)$ & Rate constant $\left(\right.$ day $\left.^{-1}\right)$ \\
\hline Untreated LAS at $100 \mathrm{mg} / \mathrm{L}$ & 5.2 & 0.1771 \\
\hline Pre-treated LAS for 15 min & 38 & 0.2538 \\
\hline Pre-treated LAS for 1.5 h & 60 & 0.2839 \\
\hline
\end{tabular}


1. LAS at the concentration of $40 \mathrm{mg} / \mathrm{L}$ without any pre-treatment,

2. Pre-treated LAS after $1.5 \mathrm{~h}$ by UV-254 and optimum concentration of $\mathrm{H}_{2} \mathrm{O}_{2}(720$ $\mathrm{mg} / \mathrm{L}$ ). Therefore, the concentration of LAS used in this experiment was reduced to $10 \mathrm{mg} / \mathrm{L}$,

3. LAS at the concentration of $10 \mathrm{mg} / \mathrm{L}$ without pre-treatment,

4. LAS at the concentration of $100 \mathrm{mg} / \mathrm{L}$ without pre-treatment.

There were some $\mathrm{H}_{2} \mathrm{O}_{2}$ residues in the pre-treated sample (the concentration of $\mathrm{H}_{2} \mathrm{O}_{2}$ was $400 \mathrm{mg} / \mathrm{L}$ after $1.5 \mathrm{~h}$ of photolytic treatment). The $\mathrm{H}_{2} \mathrm{O}_{2}$ residue was eliminated with catalase before biological shake flask process according to the calculation described in Appendix A.

During the biological treatment, the concentration of LAS was monitored to compare the degradation of untreated LAS with the one with photolytic pre-treatment. Furthermore, $\mathrm{pH}$ and dissolve oxygen (DO) were measured on a daily basis (Figure 4.21). The $\mathrm{pH}$ for all types of samples was not adjusted and sample 1,2,3, and $4 \mathrm{had} \mathrm{pH}$ equal to $6.76,6.56,6.70$, and 6.80 , respectively. Therefore, the $\mathrm{pH}$ was in the acceptable range (the acceptable range for the $\mathrm{pH}$ in the biological treatment is between 6 to 8 ). There was no significant change in $\mathrm{pH}$ during the course of the process. DO was also measured during the treatment period, to make sure there was enough oxygen for the microorganism in the system. Each sample from the shake flasks taken was divided into two parts. LAS from the first part was measured directly, but the second part was filtered with Whatmann glass fiber with pore diameter of $1.58 \mu \mathrm{m}$ (Standard Method, 1998) to separate the sludge from the liquor and then the concentration of LAS in the liquor was measured.

Initially it was observed that the concentration of LAS $(40 \mathrm{mg} / \mathrm{L})$ in the liquid phase in the untreated sample had a $16.5 \%$ decrease during the first day. However, as it is known that LAS is adsorbed to the sludge in aerobic biological treatment (Berna et al., 1989), the analysis of sludge showed that LAS had been adsorbed to the sludge up to $96 \%$. Figure 4.22 shows the changes in the degradation of LAS in the liquid and sludge 
phase. Initially, as the concentration of LAS in the liquid phase decreases, its concentration in the solid phase increased. This increase was up to 8 days and after that LAS in the sludge started to degrade. This suggests that the microorganisms in the sludge were acclimated to LAS and had been capable of degrading the LAS. The same pattern was observed in the literature (Rittmann et al., 2001). As the Figure 4.22 shows, after 31 days the concentration of LAS had not reached zero yet. Moreover, the sludge at day 31 still contained a considerable amount of LAS which was still more than the maximum contamination level. Furthermore, about $30 \%$ of the initial LAS remained in sludge, even if the effluent did not contain any LAS. This percentage of remaining LAS in this sludge was also observed in another study (Patterson et al., 2002). However, the total amount of LAS measured in the mixed phased in some days was seemed to be more than the initial concentration of LAS. This could be due to the fact that MBAS method measures the total concentration of anions rather than LAS alone, and hence, produces a positive error which means MBAS method has measured LAS plus other anions present in the solution.

On the other hand, the concentration of the pre-treated LAS reached to zero in 11 days. The concentration of LAS in the sludge had an increase from 4 to $6 \mathrm{mg} / \mathrm{L}$, but it reached to its initial concentration in 15 days (Figure 4.23). Furthermore, the degradation rate of pre-treated and untreated LAS was compared with each other (sample 2 and 3). Figure 4.24 shows the difference between these two. As Figure 4.24 shows, it is obvious that during the first day, the pre-treated LAS was degraded by $30 \%$, while the untreated LAS was degraded by $40 \%$, suggesting that pre-treated LAS was less biodegradable than untreated LAS when dealing with the low concentration of LAS $(10 \mathrm{mg} / \mathrm{L})$, due to the presence of some other organics (intermediates). The same results were obtained by comparing the $\mathrm{BOD}_{5} / \mathrm{COD}$ for photo treated LAS and untreated LAS with exactly the same concentration. The ratio for $\mathrm{BOD}_{5} / \mathrm{COD}$ for pre-treated LAS was 0.4 , while this ratio for untreated LAS at the concentration of $10 \mathrm{mg} / \mathrm{L}$ was 0.5 . This implies that untreated LAS at the concentration of $10 \mathrm{mg} / \mathrm{L}$ is more biodegradable than pre-treated LAS at this concentration. This can be due to the presence of sulfophenyl(di)carboxylates produced from photolytic pre-treatment of LAS, which have been reported to be refractory to biodegradation (Patterson et al., 2002). However, reliable conclusion could 
only be obtained by having the amount of total organic carbon (TOC) for those two types of wastewater.

The biodegradation rate of LAS in those experiments, as it was reported (Huang et al., 2000, Zhang et al., 1999), follows first order model (Figure 4.25). The pre-treated LAS followed the following model:

$$
\ln \left(\frac{C}{C_{o}}\right)=-0.0104 t+0.1128
$$

where $\mathrm{C}$ is the concentration of LAS at time $t$, and $\mathrm{C}_{\mathrm{o}}$ is the initial concentration of LAS which is equal to the concentration of the photoreactor effluent.

The biodegradation of untreated LAS at the same concentration also followed the following model:

$$
\ln \left(\frac{C}{C_{o}}\right)=-0.0188 t+0.2213
$$

It is obvious that the constant for untreated LAS should be more than pre-treated LAS at the same concentration, as the concentration of LAS decreased in untreated LAS faster than pre-treated one.

However, the untreated LAS at the initial concentration of $40 \mathrm{mg} / \mathrm{L}$ followed the following model (Figure 4.26):

$$
\ln \left(\frac{C}{C_{0}}\right)=-0.0039 t+0.113
$$

where $\mathrm{C}$ is the concentration of LAS at time $t$, and $\mathrm{C}_{\mathrm{o}}$ is the initial concentration of untreated LAS equal to $40 \mathrm{mg} / \mathrm{L}$. 


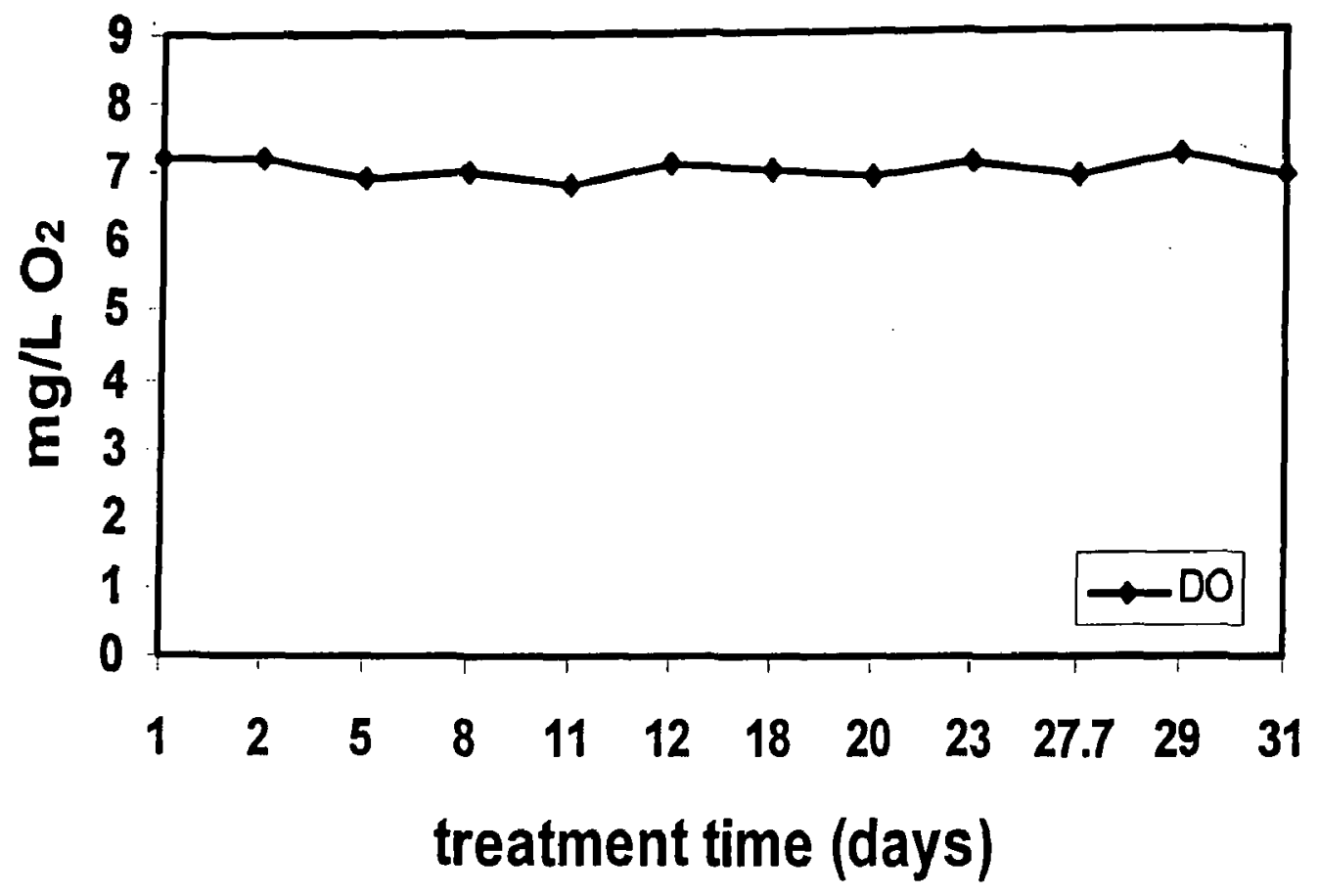

Figure 4.21. Changes in the DO during the shake flask experiment. The initial concentration of LAS was $10 \mathrm{mg} / \mathrm{L}$. 


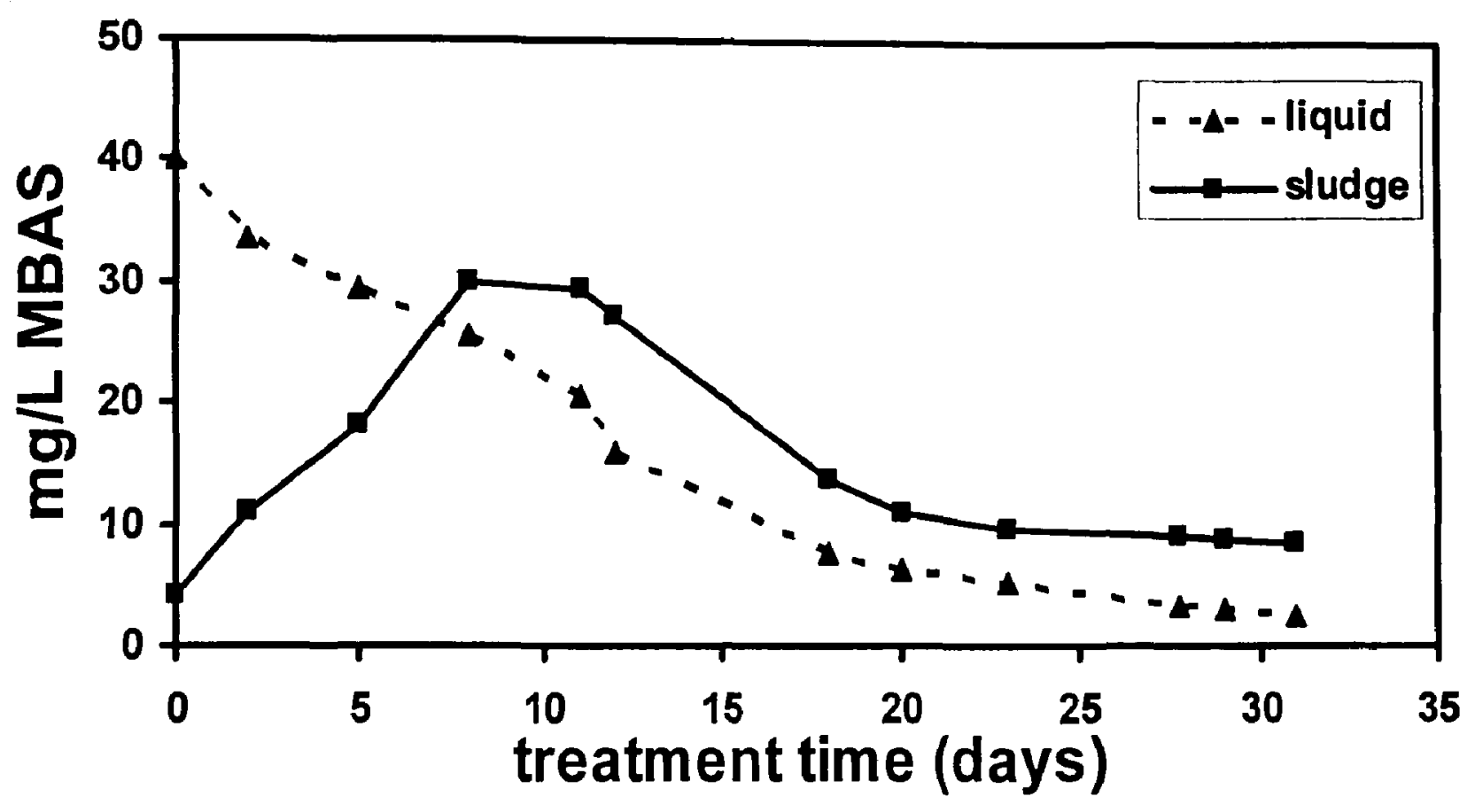

Figure 4.22: The changes in the degradation of untreated LAS at initial concentration of $40 \mathrm{mg} / \mathrm{L}$ in the liquid and solid phase in shake flask during 31 days keeping at $20^{\circ} \mathrm{C}$. 


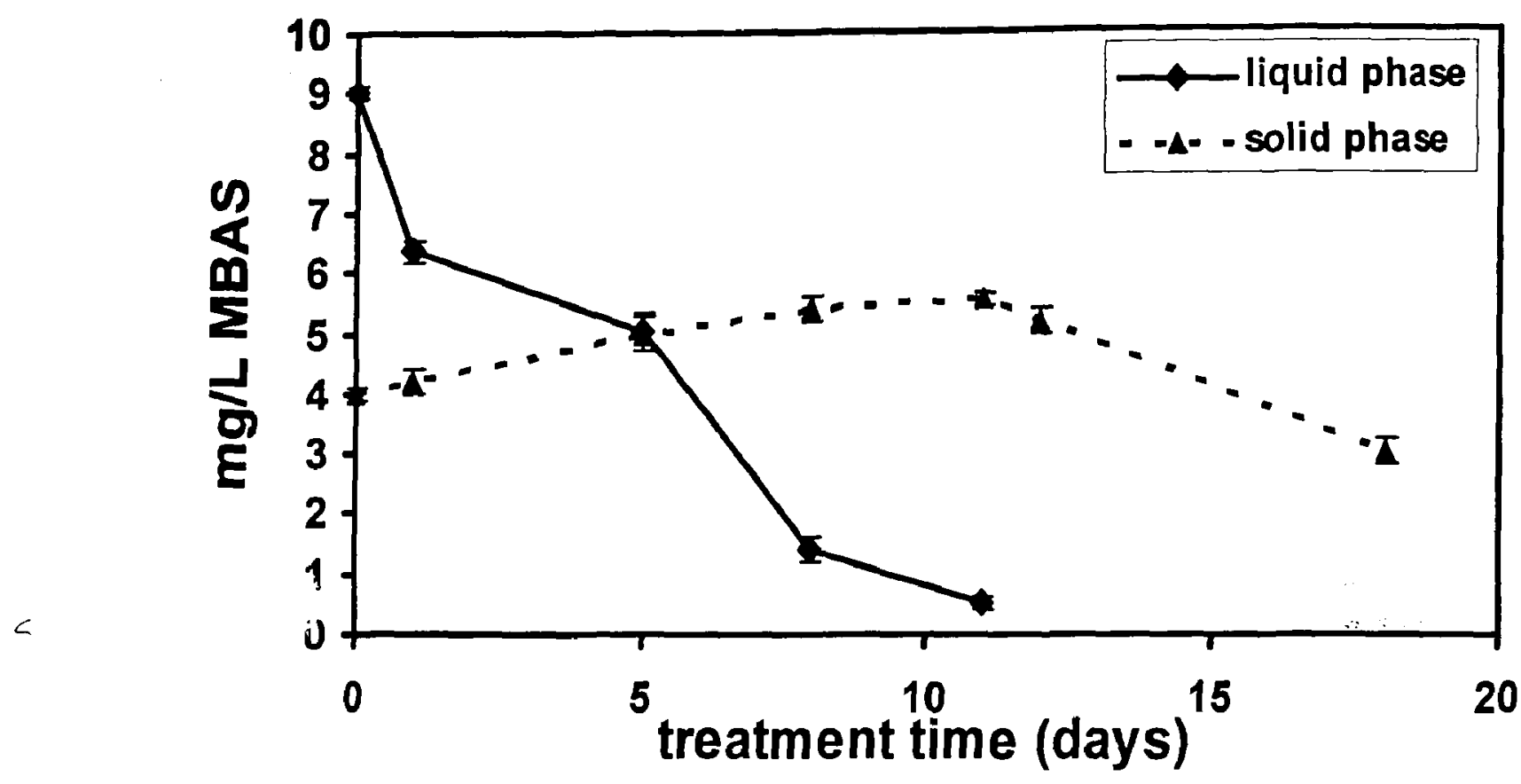

Figure 4.23: The changes in the degradation of pre-treated LAS in the liquid and solid phase in shake flask during 18 days keeping at $20^{\circ} \mathrm{C}$, the initial concentration before pretreatment was $100 \mathrm{mg} / \mathrm{L}$ and the sample was pre-treated by UV-254 and $720 \mathrm{mg} / \mathrm{L}$ of $\mathrm{H}_{2} \mathrm{O}_{2}$. The error bars represent the standard deviation of three replicate aliquots of a single sample, in which case the standard deviation represents preparation and instrument error. 


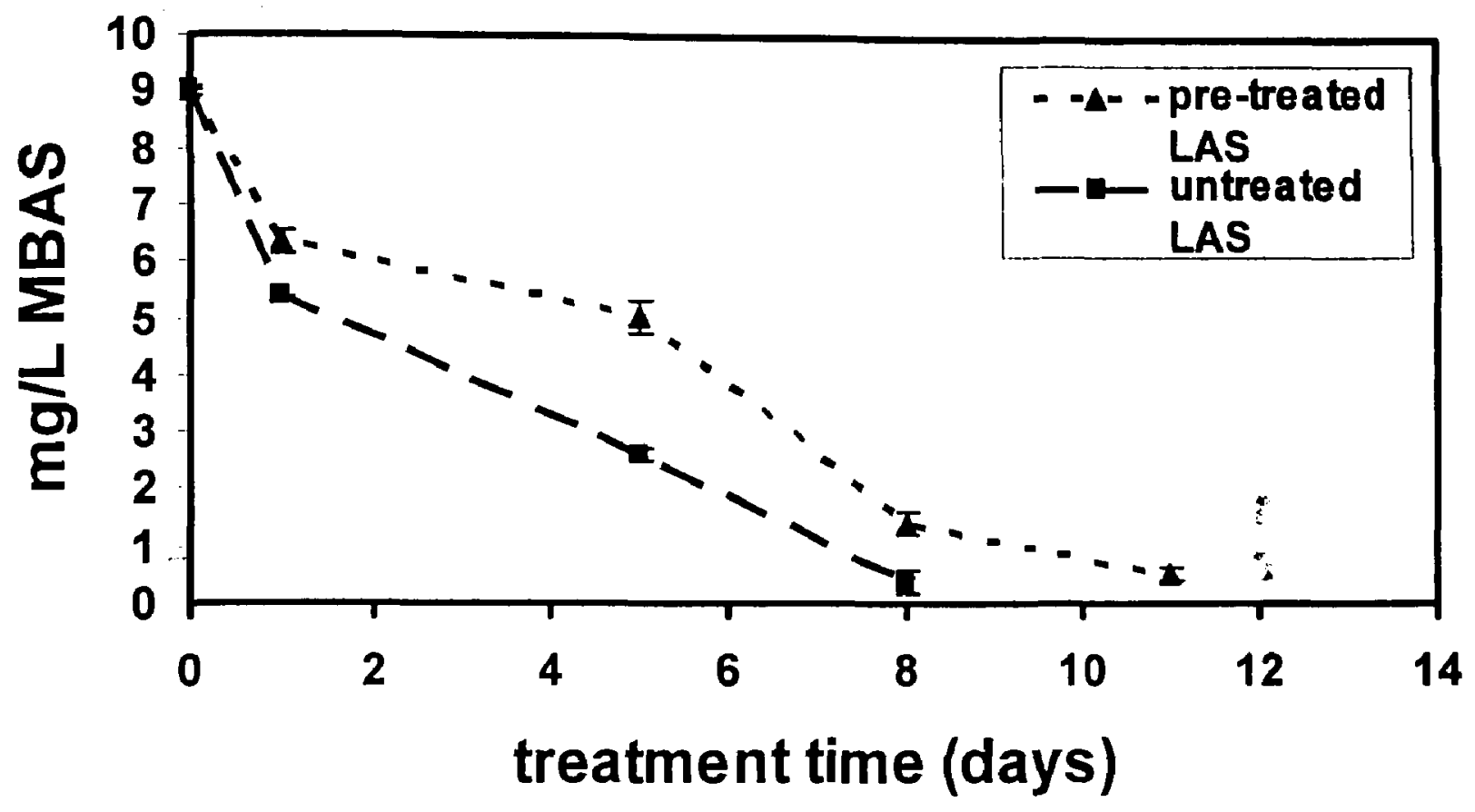

Figure 4.24: The degradation of pre-treated LAS and untreated LAS with no previous pre-treatment but at the same concentration in shake flask during 11 days keeping at $20^{\circ} \mathrm{C}$, the initial concentration for biological treatment for both was $10 \mathrm{mg} / \mathrm{L}$.

The error bars represent the standard deviation of three replicate aliquots of a single sample, in which case the standard deviation represents preparation and instrument error. 
Therefore, the constant for untreated LAS at the concentration of $10 \mathrm{mg} / \mathrm{L}$ is about 5 times faster than that of untreated LAS at $40 \mathrm{mg} / \mathrm{L}$.

The analysis of the LAS at the concentration of $100 \mathrm{mg} / \mathrm{L}$ was not successful, as the concentration of LAS did not change in the shake flask after 30 days. Moreover, the analysis of the sludge after 30 days showed a decrease in biomass weight over 30 days. This suggests that the growth rate of mixed culture of microorganisms was inhibited at the concentration of $100 \mathrm{mg} / \mathrm{L}$. This is consistent with the results obtained by Zhang et al. (1999). Furthermore, there was no visible decrease in the foaming of LAS at $100 \mathrm{mg} / \mathrm{L}$ during the period of biological treatment. Therefore, it supports the previous test $\left(\mathrm{BOD}_{5} / \mathrm{COD}=0.1\right)$ which showed that LAS at this concentration had a toxic effect on the microorganisms. As LAS at the concentration of $100 \mathrm{mg} / \mathrm{L}$ inhibited the growth of microorganisms, consequently, the microorganisms did not have the ability to degrade LAS at the concentration of $100 \mathrm{mg} / \mathrm{L}$.

\subsubsection{Biological Treatment of LAS using Sequential Batch Reactors} (SBR)

An aerobic sequential batch reactor was used to generate acclimated biomass for biological treatment of LAS (see Section 3.2.21 for more details). As the concentration of influent to the aerobic treatment (produced from chemical photolytic treatment of LAS with the optimum concentration of $\mathrm{H}_{2} \mathrm{O}_{2}$ ) was supposed to be $10 \mathrm{mg} / \mathrm{L}$, the objective of this experiment was to adapt the biomass to that concentration of LAS. The effect of acclimation on the biodegradability of LAS was studied. To increase the rate of biomass growth during the acclimation period, LAS was diluted with sodium acetate. This dilution was based on the initial characteristic of $10 \mathrm{mg} / \mathrm{L}$ LAS.

It was observed that $\mathrm{LAS}$ at this concentration had a $\mathrm{BOD}_{5}$ of about $30 \mathrm{mg} / \mathrm{L}$. Therefore, the dilution was in a way to provide the same $\mathrm{BOD}_{5}$.

It was also observed that sodium acetate at the concentration of $45 \mathrm{mg} / \mathrm{L}$ could produce

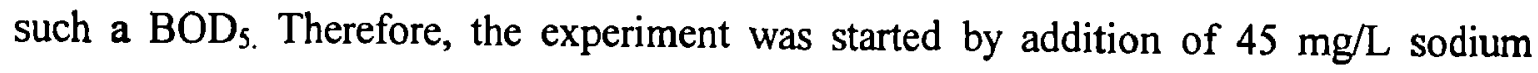
acetate to the SBR reactor. 


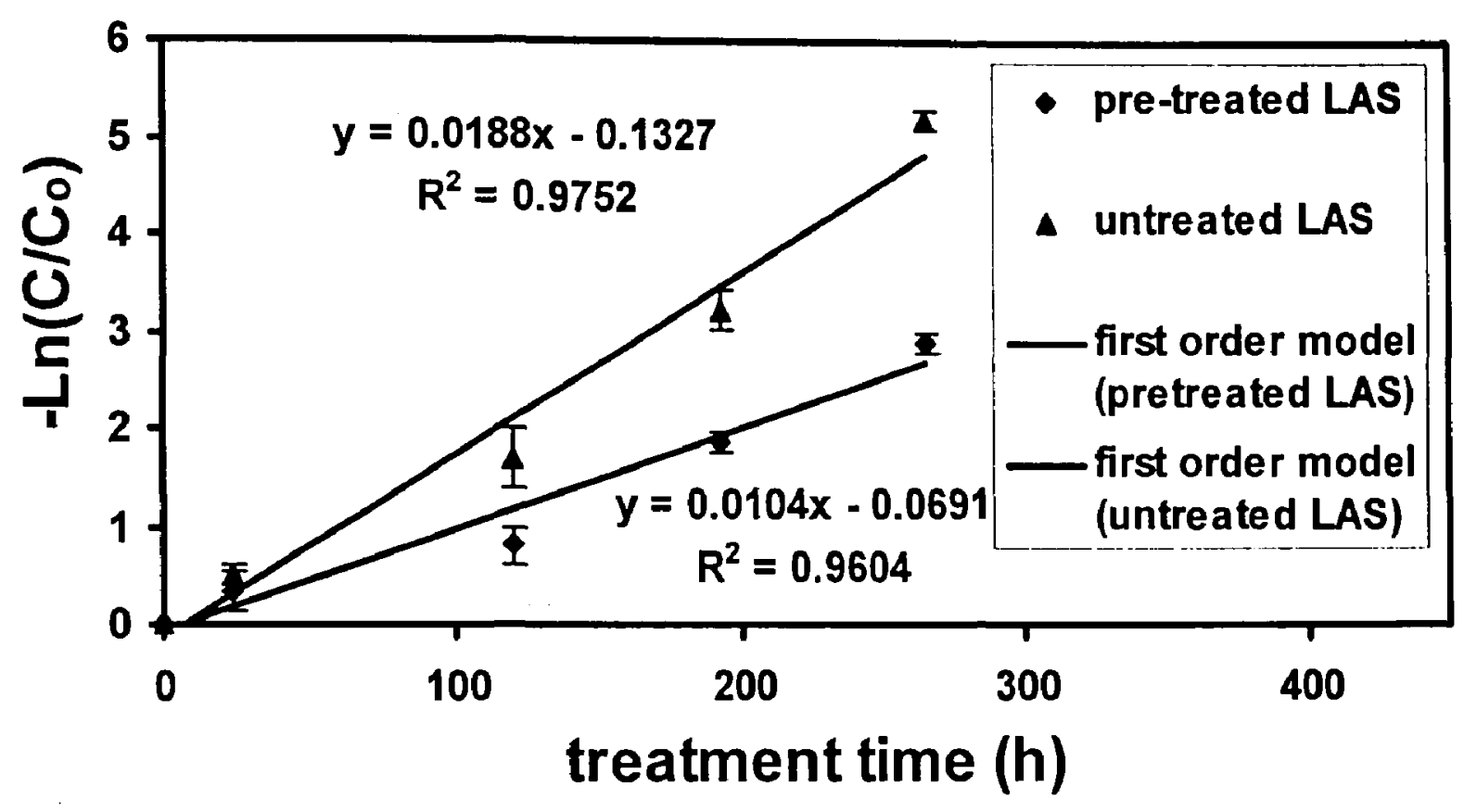

Figure 4.25: First order model for the biological degradation of two kinds of LAS in shake flasks as follows:

1. Pre-treated LAS (photolytic treatment $+\mathrm{H}_{2} \mathrm{O}_{2}$ ),

2. Untreated LAS.

The error bars represent the standard deviation of three replicate aliquots of a single sample, in which case the standard deviation represents preparation and instrument error. 


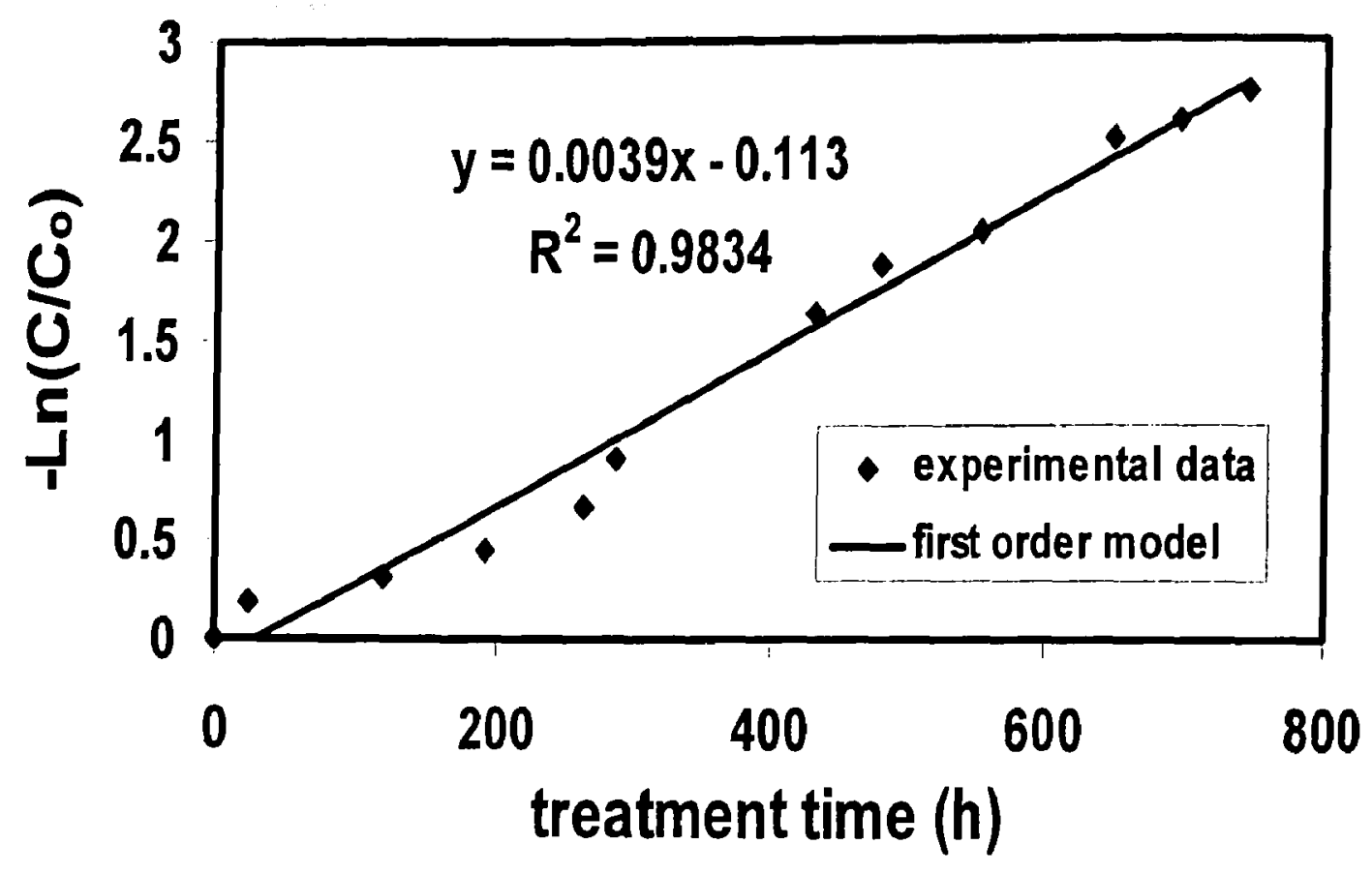

Figure 4.26. First order model for the biological degradation of untreated LAS at the initial concentration of $40 \mathrm{mg} / \mathrm{L}$. 
Moreover, activated sludge (from North Toronto Treatment Plant) and nutrient with the ratio of BOD:N:P equal to 100:5:1 were fed to the reactor. The nutrient medium was composed of $\mathrm{KH}_{2} \mathrm{PO}_{4}, \mathrm{~K}_{2} \mathrm{HPO}_{4}, \mathrm{NaHPO}_{4} .7 \mathrm{H}_{2} \mathrm{O}, \mathrm{NH}_{4} \mathrm{Cl}, \mathrm{MgSO}_{4}, \mathrm{FeCl}_{3}$, and $\mathrm{CaCl}_{2}$ (Standard Methods, 1998). The nutrients were added to the system weekly.

Air was provided by air diffuser and the system was mixed at the speed of 300 rpm. The concentration of LAS in the substrate was gradually increased according to the Figure 4.27; meanwhile, the concentration of sodium acetate was decreased to maintain $\mathrm{BOD}_{5}$ equal to $30 \mathrm{mg} / \mathrm{L}$. The addition of new substrate was provided when the changes in the concentration of LAS in the reactor became steady state, in other words the concentration of LAS became zero (Figure 4.27). The concentrations of LAS were measured at the end of settling period. $\mathrm{pH}, \mathrm{DO}, \mathrm{MLVSS}$, temperature, COD, and the concentration of LAS were monitored daily at the end of settling period. $\mathrm{BOD}_{5}$ was monitored 3 times per week. DO was almost constant at $7 \mathrm{mg} / \mathrm{L} \mathrm{O}$ (Figure 4.28), as a result, the system had always enough oxygen during the react period. Figure 4.29 shows the changes in $\mathrm{pH}$ during the acclimation period. It shows that $\mathrm{pH}$ had a slight variation, but it was always in the proper range of $\mathrm{pH}$. The temperature was around room temperature $\left(25 \pm 1^{\circ} \mathrm{C}\right)$ and was constant. The $\mathrm{BOD}_{5}$ results were almost the same during each sampling (Figure 4.28). This suggests in spite of increasing the concentration of LAS in the substrate, the microorganisms needed the same oxygen for metabolism due to acclimation to LAS. Subsequent to completing the acclimation period, the supernatant in the reactor was drawn and the reactor was filled with pre-treated LAS and nutrients. As microorganisms were acclimated to LAS, the associated lag time in the bioassays would decrease. Figure 4.30 shows the changes in the concentration of pre-treated LAS, and its $\mathrm{COD}$ and $\mathrm{BOD}_{5}$ after the adaptation of microorganisms. The concentration of LAS in the biological reactor with the acclimated microorganisms reached zero in two days. $\mathrm{COD}$ and $\mathrm{BOD}_{5}$ also had a decrease during that period, but they did not reach to zero. This might be due to the presence of some other intermediates produced during either biological or chemical treatment of LAS which were less biodegradable than LAS. Although in order to have a precise judgment of whether the concentration of the organics were increasing or decreasing, TOC results are required. Subsequent to the 
treatment of each batch, the liquid was drawn during the draw period and filled with a new influent to examine the precision of the previous experiment. The biological treatment of LAS with acclimated sludge was repeated for three times.

Figure 4.31 shows the difference between the biodegradation of pre-treated LAS with the same concentration of LAS without any previous pre-treatment. The biodegradation of pre-treated LAS and untreated LAS at the concentration of $10.5 \mathrm{mg} / \mathrm{L}$ with adapted biomass followed the same trend as using unadapted biomass in shake flask experiments. In SBR again, the biodegradation of untreated LAS was faster than pretreated LAS.

Assuming a first order model for their degradation (Figure 4.32), LAS without pretreatment had a higher rate constant $\left(\mathrm{k}=0.1312 \mathrm{~h}^{-1}\right)$ than LAS with pre-treatment $\left(\mathrm{k}=0.0616 \mathrm{~h}^{-1}\right)$. This might be due to the presence of some intermediate produced by chemical treatment of LAS which are less biodegradable than LAS. The same conclusion has reported previously by degradation of LAS by means of wet air oxidation process (Mantzavinos et al., 2001). The degradation rate of pre-treated LAS was best fitted into first order kinetic rate which is in accordance with the previous studies (Huang et al., 2000, Zhang et al., 1999).

The pre-treated LAS in the sequential batch reactor followed the following model:

$$
\operatorname{Ln}\left(\frac{C}{C_{o}}\right)=-0.0616 t
$$

where the constant $(\mathrm{k})$ is equal to $0.0616(\mathrm{~h})^{-1}$ and $\mathrm{t}(\mathrm{h})$ is reaction time. Time can also be expressed in minute (Figure 4.33) as follows:

$\operatorname{Ln}\left(\frac{C}{C_{0}}\right)=-0.001 t$ 


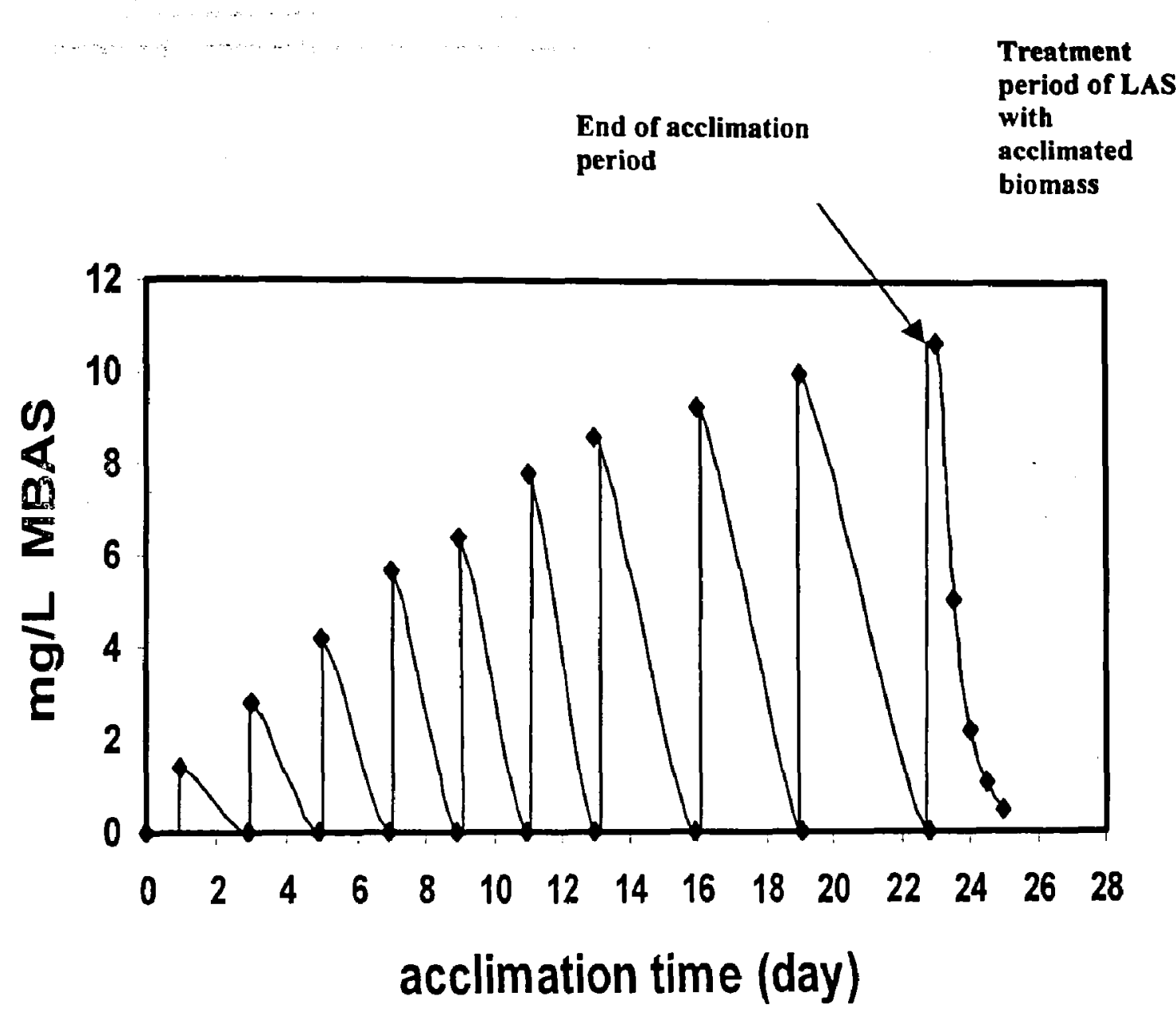

Figure 4.27. Gradual increase in the concentration of LAS which was added to the SBR during the acclimation period. This addition was done when the previous concentration of LAS in the SBR reached zero. 


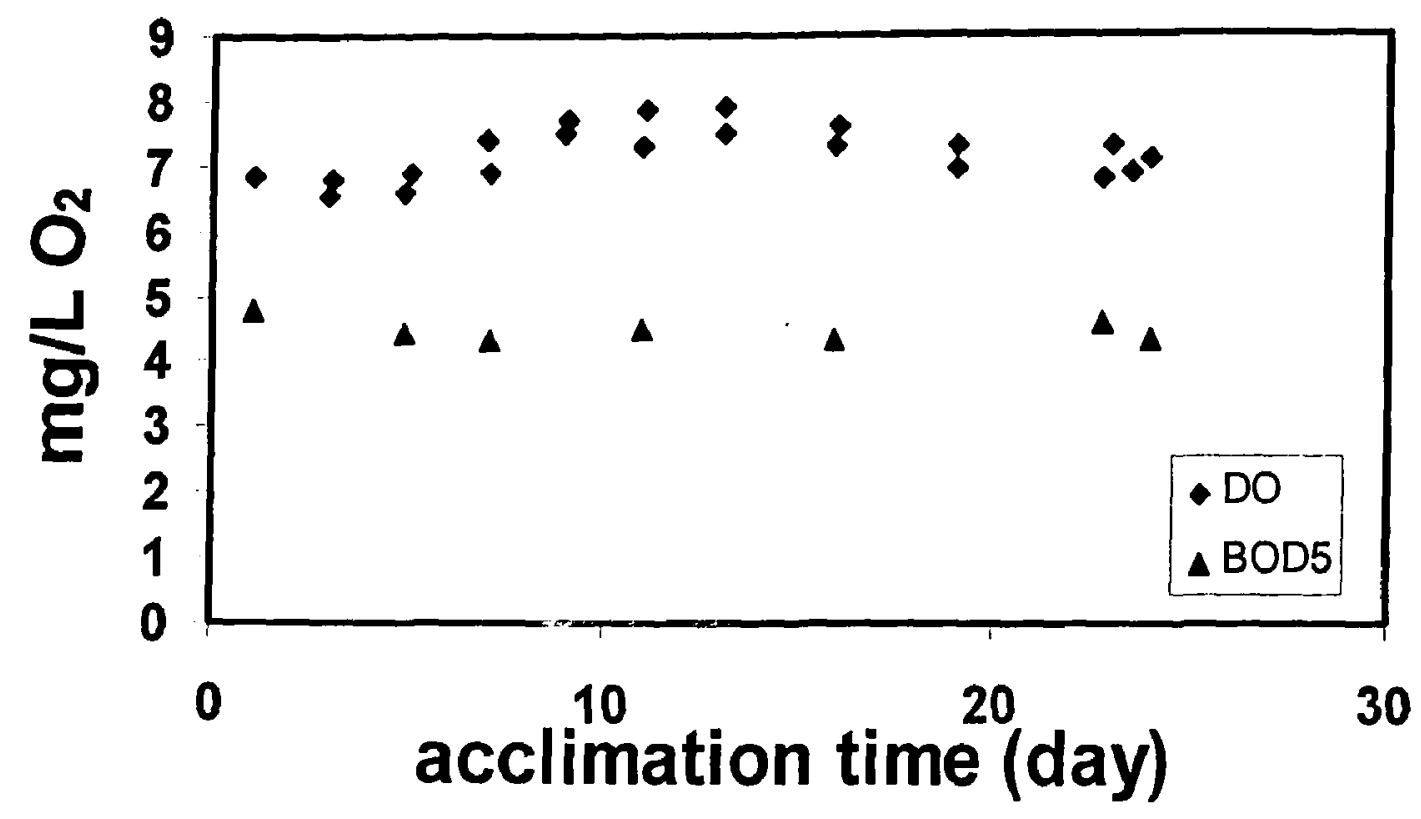

Figure 4.28. Changes in the $\mathrm{DO}$ and $\mathrm{BOD}_{5}$ during the acclimation period of $\mathrm{LAS}$ at the initial concentration of $10 \mathrm{mg} / \mathrm{L}$. 


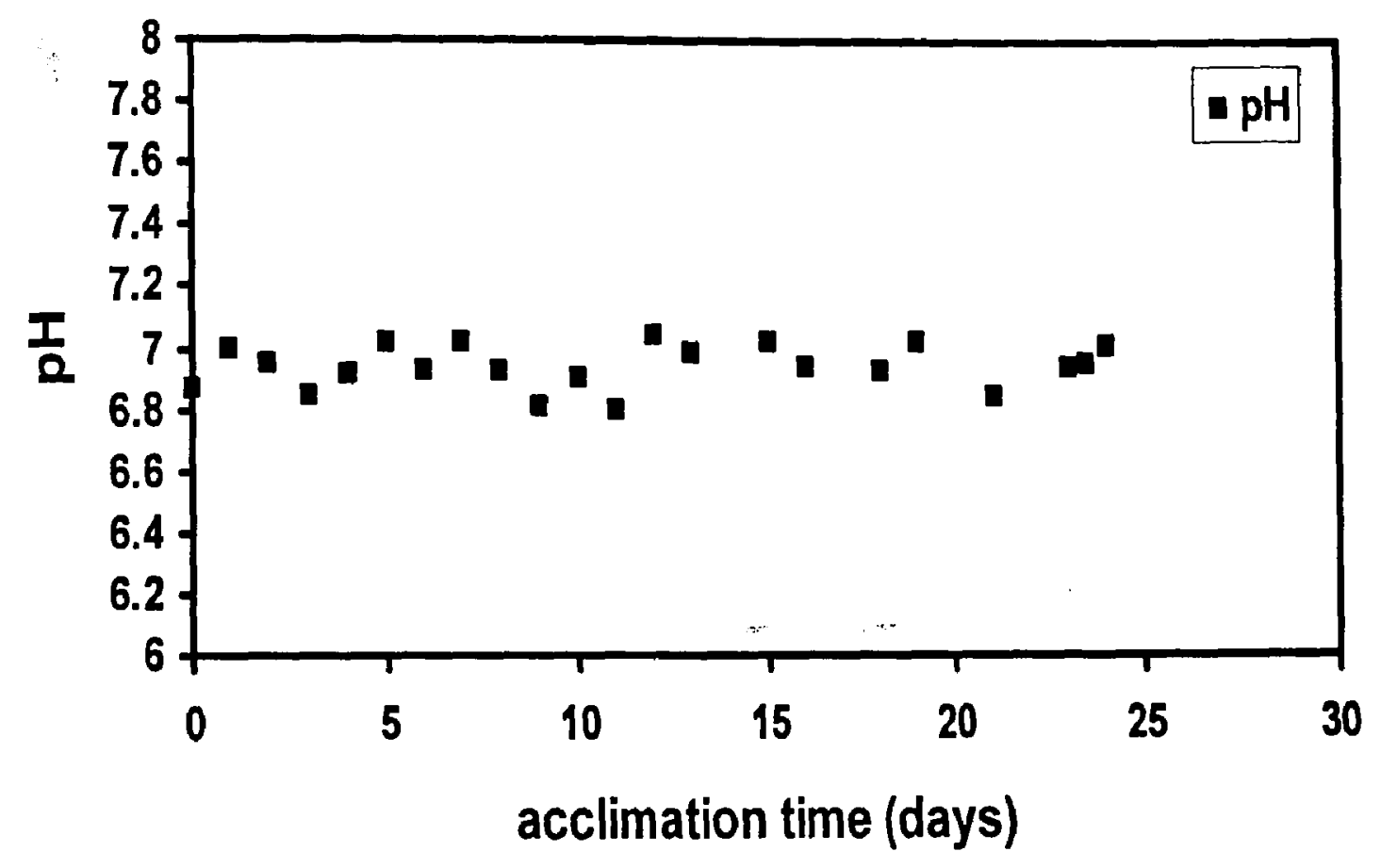

Figure 4.29. Changes in the $\mathrm{pH}$ during the acclimation period of LAS at the initial concentration of $10 \mathrm{mg} / \mathrm{L}$. 


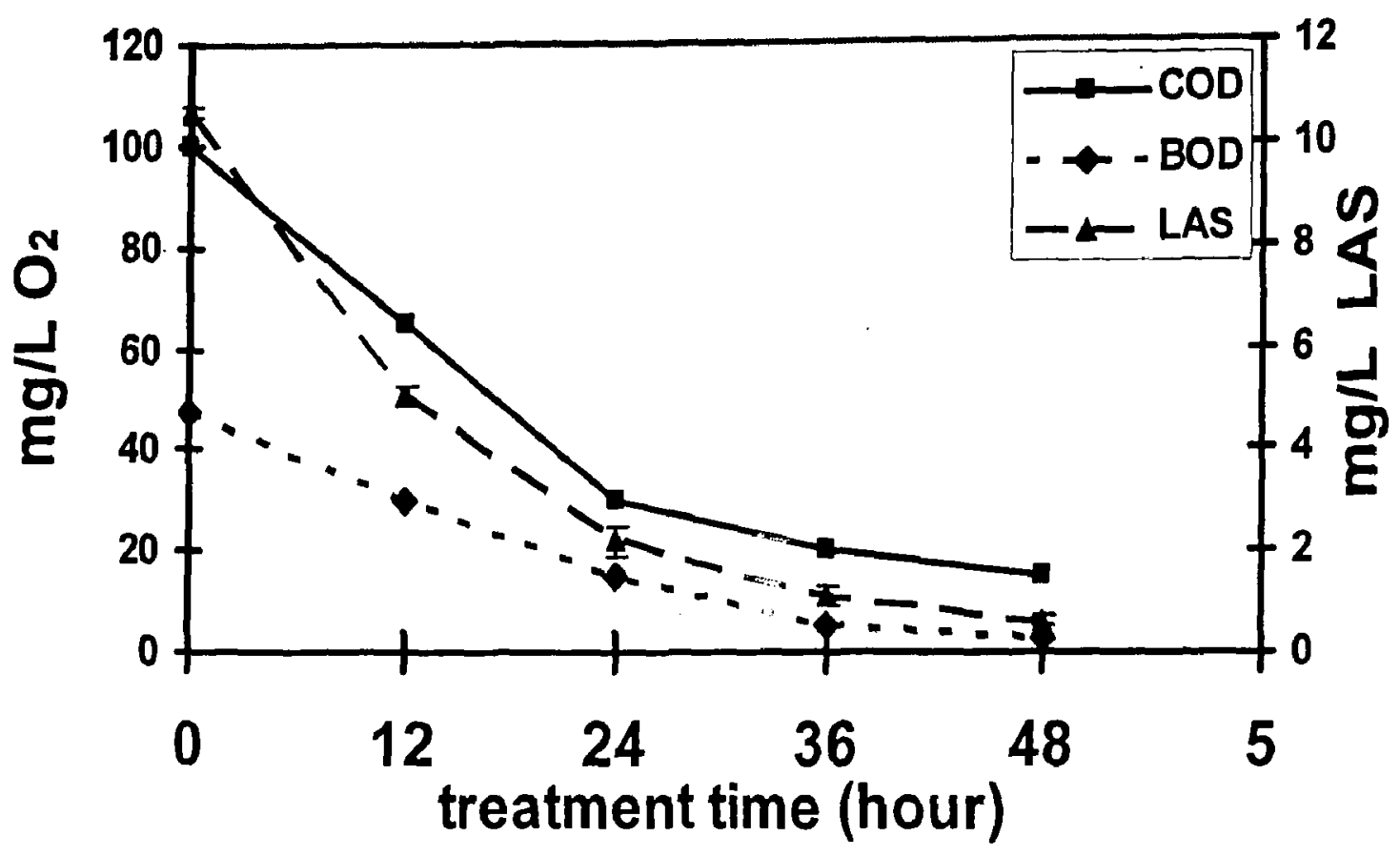

Figure 4.30: Changes in the concentration of pre-treated LAS, and its COD, and BOD $_{5}$ after the adaptation of microorganisms during 48 hours. Initial concentration of LAS was $10 \mathrm{mg} / \mathrm{L}$ at the beginning of biological treatment. The error bars represent the standard deviation of three replicate aliquots of a single sample, in which case the standard deviation represents preparation and instrument error. 
where $\mathrm{C}_{\mathrm{o}}$ is the initial concentration of LAS in the influent of biological reactor and $\mathrm{k}$ is equal to $0.001(\mathrm{~min})^{-1}$.

Table 4.2 shows different rate constants for different types of LAS for adapted and non-adapted microorganisms. It can be concluded that biodegradation of LAS with adapted microorganisms had higher constants both for untreated and pre-treated LAS. Moreover, untreated LAS had higher rate constants than pre-treated LAS with the same initial concentration.

\subsection{Comparison between Combination of Photochemical and Biological Processes for the Treatment of LAS versus Photochemical Treatment alone}

As it was mentioned before, LAS at the concentration of $100 \mathrm{mg} / \mathrm{L}$ has inhibitory effect to the microorganisms, therefore, it cannot be treated by biological processes alone. It cannot also be discharged to the environment as its maximum contamination level in ground water is $0.5 \mathrm{mg} / \mathrm{L}$ (EPA, 2004). Consequently, there should be a reliable treatment method to decrease its concentration to the desired level. The photolytic treatment of LAS with $\mathrm{H}_{2} \mathrm{O}_{2}$ is promising for its degradation; however, the operation cost of peroxide treatment is about 10 times more than that of activated sludge treatment (Esplugas and Ollis, 1997). Therefore, an attempt was made to combine these two processes to achieve $o$ a cost efficient method. It was observed that pre-treatment by $\mathrm{UV} / \mathrm{H}_{2} \mathrm{O}_{2}$ could increase the biodegradability of LAS (with the initial concentration of $100 \mathrm{mg} / \mathrm{L}$ ) by $30 \%$ (measured by $\mathrm{BOD}_{5}$ test). However, different residence times for both chemical and biological reactors may be applied. No specific residence time for either chemical or biological processes could be suggested unless considering a time that optimizes the treatment cost for this combination. In the following sections the relative cost of utilizing combination of photochemical and biological treatment has been compared versus photo-chemical treatment alone. As this is only a comparison, no treatment cost has been calculated and only their relative costs versus each other has been compared. 


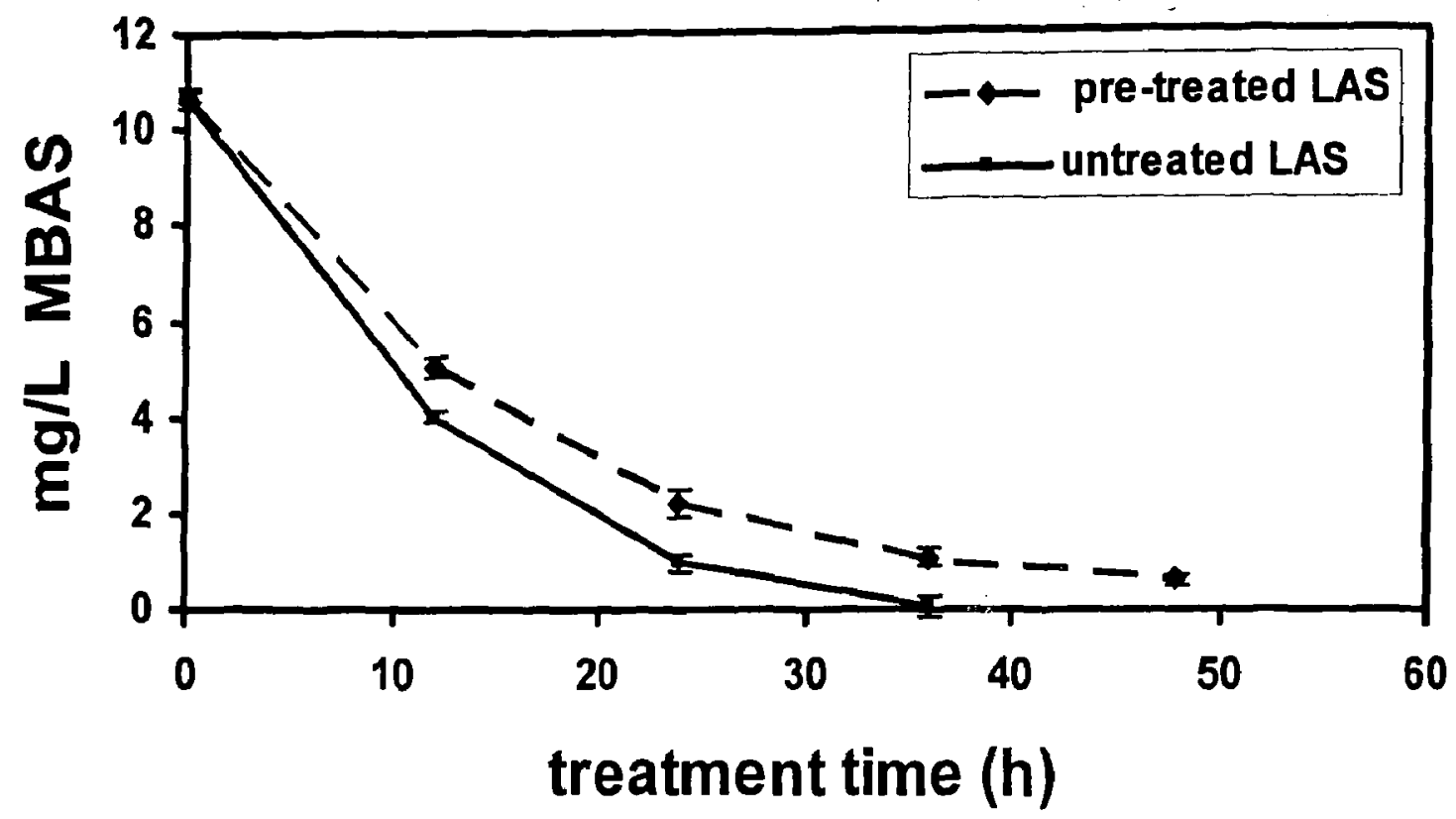

Figure 4.31: The difference between the biodegradation of pre-treated LAS with the same initial concentration of LAS without any pre-treatment in SBR with adapted microorganisms, the initial concentration of LAS was $10.5 \mathrm{mg} / \mathrm{L}$. The error bars represent the standard deviation of three replicate aliquots of a single sample, in which case the standard deviation represents preparation and instrument error. 


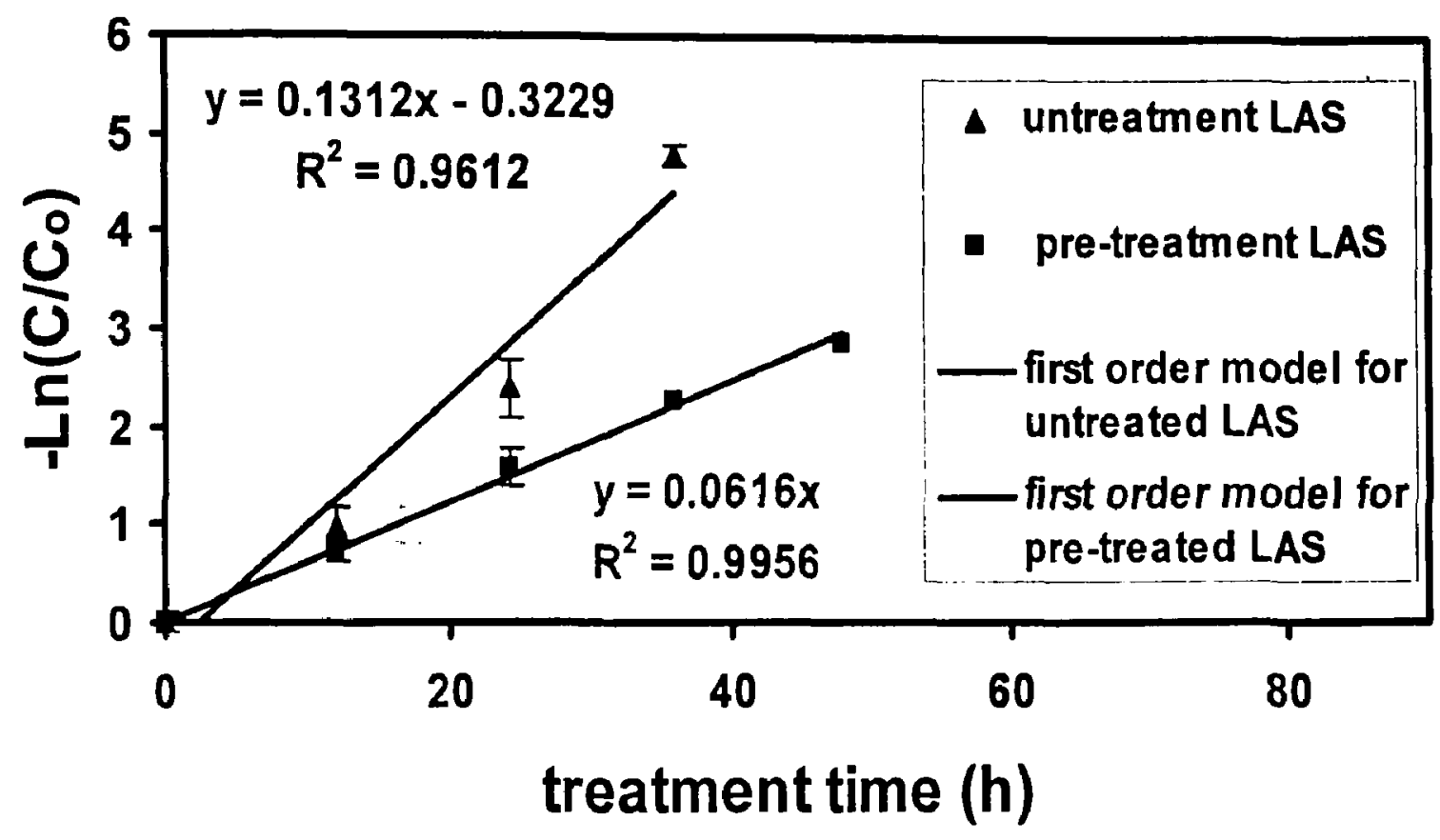

Figure 4.32: First order model for the biological degradation of LAS in SBR with adapted microorganisms. The error bars represent the standard deviation of three replicate aliquots of a single sample, in which case the standard deviation represents preparation and instrument error. 


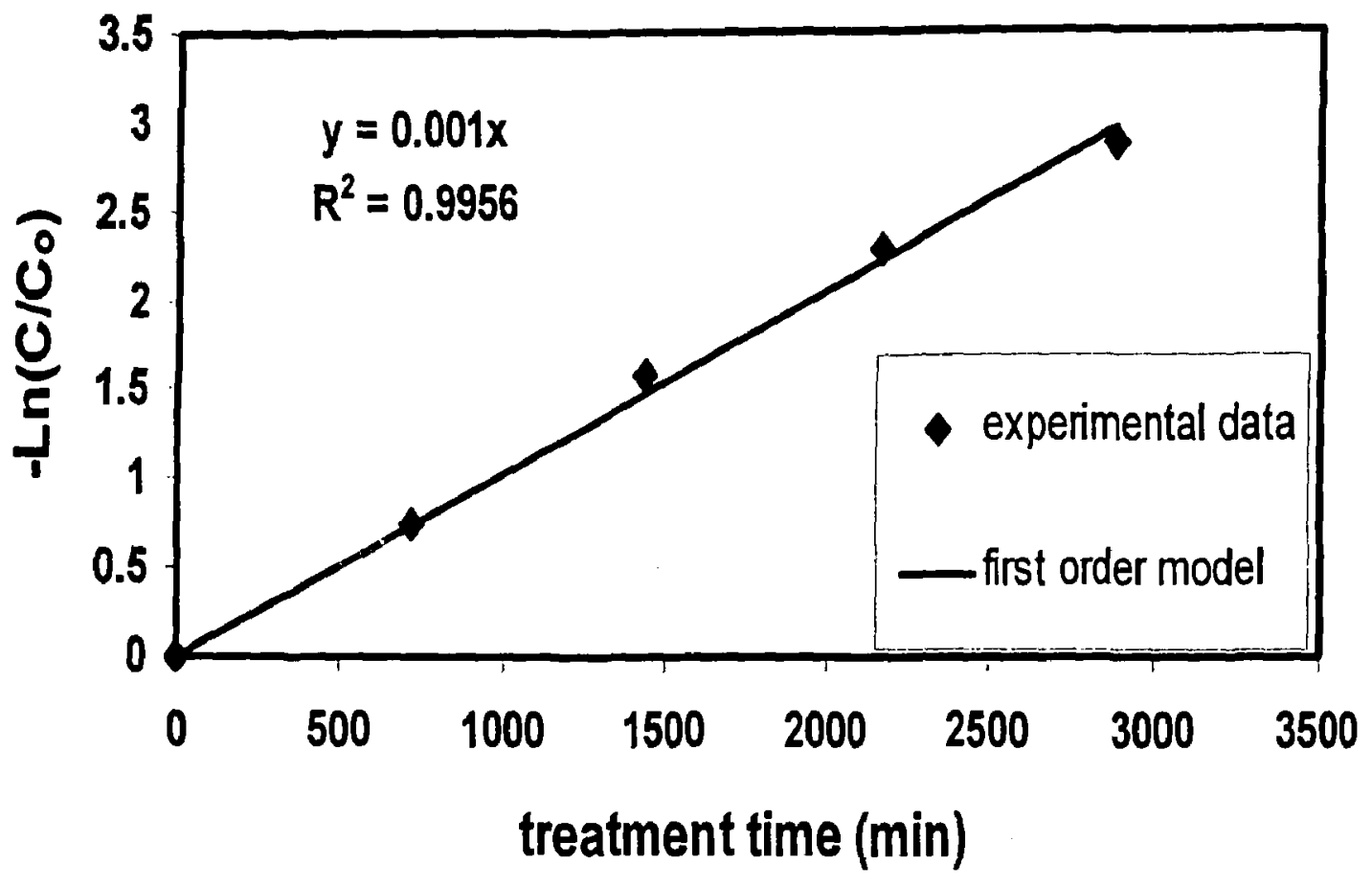

Figure 4.33: Comparison between experimental data for biological treatment pre-treated LAS in SBR with simulated data of first order model. The treatment time is considered in minute. 
Table 4.2. Constants for first order model of removal of LAS in shake flasks (nonadapted microorganisms) and SBR (adapted microorganisms).

\begin{tabular}{|c|c|c|}
\hline Process & $\begin{array}{c}\text { Adapted } \\
\text { microorganisms }\end{array}$ & $\begin{array}{c}\text { Non-adapted } \\
\text { microorganisms }\end{array}$ \\
\hline $\begin{array}{c}\text { Pre-treated LAS at } 10 \\
\mathrm{mg} / \mathrm{L}\end{array}$ & $0.0616 \quad \mathrm{~h}^{-1}$ & $0.0104 \mathrm{~h}^{-1}$ \\
\hline Untreated LAS at $10 \mathrm{mg} / \mathrm{L}$ & $0.1312 \quad \mathrm{~h}^{-1}$ & $0.0188 \mathrm{~h}^{-1}$ \\
\hline
\end{tabular}




\subsubsection{Characteristics of the Integration of Photochemical and Biological processes}

The combined system for the treatment of LAS at $100 \mathrm{mg} / \mathrm{L}$ is defined as follows: Compound A (LAS) is fed into the combined process. The combination consists of a photolytic reactor followed by a SBR. Therefore, compound A is first fed into the photolytic reactor and degrades into biodegradable compounds. However, only one of the measurable and significant intermediate for LAS is considered for the simplicity purposes. Moreover, the reaction time in the chemical reactor is set to degrade compound A perially. The effluent (consists of $A$ and intermediate $S$ ) is then fed into the bioreactor for complete degradation. The objective is to define an optimai residence time in chemical and biological reactors that minimizes the relative cost of the combined processes.

The total residence time is defined by Equation (2.17) and the overall, chemical, and biological efficiencies are defined by Equations (2.18), (2.19), and (2.20), respectively.

The overall system in the chemical process acted as a batch reactor. $\mathrm{H}_{2} \mathrm{O}_{2}$ was used as an oxidant and the optimum concentration of $\mathrm{H}_{2} \mathrm{O}_{2}$ is known. It is assumed that the main intermediate produced by degradation of LAS with UV-254/ $\mathrm{H}_{2} \mathrm{O}_{2}$ was known to be sodium benzene sulfonate. Therefore, the intermediate was produced during the degradation of LAS and then undergo photolytic degradation defined by first-order kinetics as follows:

$$
A \stackrel{k_{d}}{\longrightarrow} S \stackrel{k_{s}}{\longrightarrow} R
$$

where $\mathrm{S}$ is the intermediate and $\mathrm{R}$ is final product from the degradation of the intermediate $S$ in chemical reactor, preferably it is the complete mineralization of $S$.

LAS was observed to follow the first order kinetic model with respect to LAS during its photolytic degradation (Equation 4.5): 
$\operatorname{Ln}\left(\frac{C_{A}}{C_{A^{\prime \prime}}}\right)=-0.032 t$

where $C_{A}$ is the concentration of LAS at time $t$, and $C_{A 0}$ is initial concentration of LAS which was $100 \mathrm{mg} / \mathrm{L}$.

The concentration of $\mathrm{S}$ in this study could be written as the following expression:

$$
\frac{C_{S}}{C_{A D}}=\frac{k_{A}}{k_{S}-k_{A}}\left(e^{-k_{A^{\prime}} c^{\prime}}-e^{-k_{S^{\prime} c^{\prime}}}\right)
$$

where $C_{S}, C_{A}, C_{A 0}, k_{A}, k_{S}$, and $t_{c}$ are the concentration of $S$ in the chemical reactor effluent at time $t$, the concentration of $A$ at time $t$, initial concentration of $A$, first-order rate constant for $\mathrm{A}$, first-order rate constant for $\mathrm{S}$, and the residence time in chemical reactor, respectively. It is supposed that the intermediate still posses the benzene ring, as the breakage of aromatic ring is unlikely due to its high bond energy. Therefore, the degradation constant for the intermediate was assumed to be smaller than that of LAS, as a result it was supposed to be equal to $0.001 \mathrm{~min}^{-1}$.

The effluent of chemical reactor with $t_{c}$ minutes of residence time enters into the biological reactor. However, due to the high concentration of $\mathrm{H}_{2} \mathrm{O}_{2}$ in the effluent of chemical reactor, the residues of $\mathrm{H}_{2} \mathrm{O}_{2}$ should be eliminated first. That effluent contains both LAS and its intermediate. As the objective was to decrease the concentration of LAS to $0.5 \mathrm{mg} / \mathrm{L}$ (maximum contamination level set by $\mathrm{EPA}$ ), the solution remains in biological reactor until it meets that concentration. In the bioreactor, it was observed that the degradation of LAS follows the first order reaction model as mentioned in Equation (4.14):

$$
\operatorname{Ln}\left(\frac{C}{C_{0}}\right)=-0.001 t
$$

where $\mathrm{C}$ is the concentration of LAS in the bioreactor at time $t$ and $\mathrm{C}_{\mathrm{o}}$ is the initial concentration in the bioreactor which was equal to the concentration of LAS in the 
effluent of chemical reactor. The degradation of intermediate was also assumed to follow first order reaction model as follows:

$$
\operatorname{Ln}\left(\frac{C_{S B}}{C_{S}}\right)=-k t
$$

where $\mathrm{C}_{\mathrm{SB}}, \mathrm{C}_{\mathrm{S}}$, and $\mathrm{k}$ are the concentrations of intermediate at time $\mathrm{t}$ in the bioreactor, initial concentration of intermediate in the bioreactor which was equal to the concentration of intermediate in the effluent of the chemical reactor, and the first order reaction constant $\left(\mathrm{min}^{-1}\right)$ for the biodegradation of the intermediate, respectively.

During the biological experiments, it was observed that the intermediate produced during the photolytic degradation of LAS was less biodegradable than LAS (which might be due to the high concentration of intermediate at that time). $k$ for the degradation of intermediate was assumed to be equal to $0.0009 \mathrm{~min}^{-1}$ which is less than the constant for the biodegradation of untreated LAS.

The chemical efficiency was defined as the reduction in concentration in AOP over $100 \%$ reductions in concentration of LAS; therefore, it can be expressed as follows (Scott and Ollis, 1996):

$$
X=\frac{C_{A_{u}}-\left(C_{A}+C_{S}\right)}{C_{A_{u}}}
$$

where $C_{A 0}, C_{A}$, and $C_{S}$ are the initial concentration of LAS equal to $100 \mathrm{mg} / \mathrm{L}$, the concentration of LAS in the effluent of chemical reactor at time $t$, and the concentration of intermediate at time $t$ equal to $t_{C}$ in the effluent, respectively.

The biological efficiency was also expressed as reduction in the concentration of compounds in the biological reactor versus $100 \%$ concentration reduction (Scott and Ollis, 1996):

$$
Y=\frac{\left(C_{A}+C_{S}\right)-\left(C_{A B}+C_{S B}\right)}{C_{A}}
$$


where $\mathrm{C}_{\mathrm{AB}}$ and $\mathrm{C}_{\mathrm{SB}}$ are the concentrations of LAS and the concentration of intermediate in the effluent of biological reactor at time $t$ equal to $t_{B}$. Therefore the total efficiency is equal to(Scott and Ollis, 1996):

$$
Z=X+Y=\frac{C_{A_{\mathrm{o}}}-\left(C_{A B}+C_{S B}\right)}{C_{A o}}
$$

where $\mathrm{Z}$ is the global efficiency. Consequently, as AOPs are more expensive than the biological treatment, ideally most organic removal should occur in biological stage (Patterson et al., 2002). Therefore, Y should be greater than X.

The objective function for the optimization of the integration of biological and chemical processes for this example is as follows (Esplugas and Ollis, 1997):

$$
\mathrm{C}=\mathrm{tB}_{\mathrm{B}}^{\mathrm{b}}+\mathrm{at}_{\mathrm{C}}^{\mathrm{c}}
$$

where $C$ is the relative cost function and $a(a \geq 1)$, and $b(b=0.6)$ and $c(c=0.6)$ are the volumetric cost ratio between $\mathrm{AOP}$ and biological reactor, and time constants, respectively. The volumetric cost is the ratio for the operating cost of chemical to biological treatment per each volume of wastewater treated. The relative cost is used as a tool to compare of different combinations of chemical and biological processes from the economic point of view. It is not the actual cost of treatment, and higher values of the relative cost imply that the treatment cost would be higher. On the other hand, the low value of relative cost shows lower treatment cost. In other words, the relative cost expresses the ratio of chemical treatment to biological treatment cost. b was chosen equal to 0.6 as in the absence of the actual cost and when it is necessary to estimate the cost of equipment, good results can be obtained by using six-tenths-factor rule (Peters and Timmerhaus, 1991). Moreover, simply combining the treatment time in bioreactor and chemical reactor was not possible as the residence time in chemical reactor is 50 times less than that of biological reactor. However, the operating cost of chemical treatment is 10 times more than biological treatment. 
The constraints for this optimization example are set as follows:

a) equality constraints:

$\eta_{G}=Z=\frac{C_{A v}-C_{A B}-C_{S B}}{C_{A v}}=0.95 \quad$ (the desired efficiency is $95 \%$ )

where $\eta_{G}, \mathrm{C}_{\mathrm{AO}}, \mathrm{C}_{\mathrm{AB}}$, and $\mathrm{C}_{\mathrm{SB}}$ are total (global) efficiency, the initial concentration of pollutant $(\mathrm{mg} / \mathrm{L})$, the concentration of the LAS in the bioreactor effluent $(\mathrm{mg} / \mathrm{L})$, and the concentration of intermediate in the bioreactor influent $(\mathrm{mg} / \mathrm{L})$, respectively.

b) inequality constraints:

$$
\begin{aligned}
0 \leq C_{A} \leq C_{A 0} \\
C_{S} \geq 0 \\
t_{C} \geq 0 \\
t_{B} \geq 0 \\
C_{A B} \leq 0.5 \mathrm{mg} / L
\end{aligned}
$$

where $C_{S}, C_{A B}, t_{B}$, and $t_{C}$ are the concentration of intermediate leaving chemical reactor ( $\mathrm{mg} / \mathrm{L}$ ), the concentration of the LAS in the bioreactor effluent $(\mathrm{mg} / \mathrm{L})$, the residence time in the bioreactor, and residence time in chemical reactor, respectively. The residence times are chosen to be positive as negative residence time is not acceptable in the process and that is the same for the concentrations. Moreover, it is expected that the concentration of $\mathrm{A}$ in the effluent should be less than the inlet concentration of $\mathrm{A}$ in the chemical reactor.

\subsubsection{Solution of the Optimization Procedures}

According to the Equation 4.21, the applicable method is nonlinear equation with constraints. Therefore, the problem was solved numerically. The GRG2 (generalized reduced gradient) code is used to solve the model. Constant "a" in Equation (4.24) was chosen to be 10 as it is reported that the cost of peroxide treatment is about 10 times of 
activated sludge treatment (Esplugas and Ollis, 1997). Constants " $b$ " and "c" were chosen to be 0.6 for the same reason as suggested in a previous study (Esplugas and Ollis, 1997). Therefore, the objective function which provides an indication of the relative costs of the combined system would be in the form of:

$$
\mathrm{C}=\mathrm{t}_{\mathrm{B}}{ }^{0.6}+10 \mathrm{t}_{\mathrm{C}}{ }^{0.6}
$$

After solving the objective function of Equation (4.28) along with the constraints in Equations (4.22-4.27), the results of the optimization are summarized in Table 4.3. As indicated in Table 4.3, the residence time in the chemical and biological reactors are 61.51 and 3365.58 minutes, respectively. Those residence times lead to decrease the concentration of $\mathrm{A}$ from $100 \mathrm{mg} / \mathrm{L}$ to $13.88 \mathrm{mg} / \mathrm{L}$ in chemical reactor. Meanwhile, in the bioreactor, the concentration of $S$ decreases from $82.72 \mathrm{mg} / \mathrm{L}$ to $4 \mathrm{mg} / \mathrm{L}$. This configuration minimizes the total cost of these integrated processes. Many other combinations for this global efficiency is possible that might even further decrease the final concentration of the biological effluent, but these residence times for photolytic and biological reactors are the most cost effective one. Moreover, as it was mentioned before, in this combination, the efficiency of chemical reactor is much less than the efficiency of the biological reactor. If only the goal was to reach the efficiency of the photochemical reactor to $95 \%$, it was estimated that the residence time in the chemical reactor should be $2940 \mathrm{~min}$. This residence time would give a relative cost of equal to 1205 , while the concentration of the intermediates reached to $5.4 \mathrm{mg} / \mathrm{L}$. Moreover, the LAS at the initial concentration of $100 \mathrm{mg} / \mathrm{L}$ did not have the ability to be degraded biologically. Therefore, LAS at the concentration of $100 \mathrm{mg} / \mathrm{L}$ could not be treated by biological treatment alone.

Figure 4.34 illustrates the degradation of compound $A$ and formation of compound $S$ during the course of the reaction in the chemical reactor. It is clear that the rate of degradation of $\mathrm{A}$ and formation of $\mathrm{S}$ are influenced by their rate constants. Decreasing the rate constant of degradation of $S$ can lead to increase the concentration of $S$ in the 
Table 4.3: Optimization results for the combination of photochemical $\left(U V / \mathrm{H}_{2} \mathrm{O}_{2}\right)$ and biological (activated sludge, SBR) processes for the treatment of LAS

\begin{tabular}{|c|c|}
\hline Parameter & Values \\
\hline$t_{c}$ & $61.51 \mathrm{~min}$ \\
\hline$t_{B}$ & $3365.58 \mathrm{~min}$ \\
\hline$\mu_{G}$ & 0.95 \\
\hline $\mathrm{C}_{\mathrm{A}}$ & $13.88 \mathrm{mg} / \mathrm{L}$ \\
\hline$C_{A B}$ & $0.5 \mathrm{mg} / \mathrm{L}$ \\
\hline $\mathrm{C}_{S A}$ & $82.72 \mathrm{mg} / \mathrm{L}$ \\
\hline $\mathrm{C}_{S B}$ & $4.00 \mathrm{mg} / \mathrm{L}$ \\
\hline$\mu_{c}$ & 0.04 \\
\hline$\mu_{B}$ & 0.91 \\
\hline Relative cost & $\begin{array}{ll}249.10 \quad & \$ / \text { volume of wastewater } \\
\text { treated } / \mathrm{min}\end{array}$ \\
\hline Residue $\mathrm{H}_{2} \mathrm{O}_{2}$ & $471.0 \mathrm{mg} / \mathrm{L}$ \\
\hline
\end{tabular}


photo-reactor's effluent, and hence, the concentration of the intermediate increases in the bioreactor. Therefore, the rate constant of the $S$ in the bioreactor decreases. Consequently, decreasing the degradation rate of $\mathrm{S}$ alone did not show significant effect on the relative cost. As decreasing it by 4 orders of magnitudes, only it reduced the relative cost by $2 \%$. Therefore, in the optimization of the relative cost of the combination, the degradation rate constant of LAS has a significant effect. This can be due to the assumption that LAS do not mineralize completely during pre-treatment and only produces intermediates with high bond energy that are supposed to be mineralized in the biological step. If these intermediates had a rate constant higher than the LAS degradation rate constant in the chemical stage, they would degrade faster than LAS and the chemical effluent contains almost no intermediate. This cannot be true due to the following reasons:

1. The biodegradability tests showed that the effluent from the chemical reactor is less biodegradable than LAS at the same concentration, when dealing with LAS at lower concentrations $(10 \mathrm{mg} / \mathrm{L})$, and this is due to presence of intermediates which are less biodegradable than LAS at the concentration of $10 \mathrm{mg} / \mathrm{L}$.

2. The COD test after pre-treatment showed little decrease. If it was true and the intermediates had the ability to be degraded rapidly, there should be a sharp decrease in the COD during the pre-treatment, as the concentration of organics were decreasing rapidly

3. As the intermediate contains aromatic ring, the breakage of this ring is more difficult than the breakage of the side chains. Therefore, the degradation of an intermediate with high bond energy is slower than its production, which is due to the breakage of the side chain of LAS.

As a result, the assumption that the degradation of the intermediate was less than the degradation of LAS was a correct assumption.

The optimum operating conditions occur due to the design constraints and the global residence time. Using the integration of chemical and biological processes for LAS treatment instead of single step of AOP appears to reduce the total residence time in both chemical and biological reactors while obtaining the desired total efficiency. 


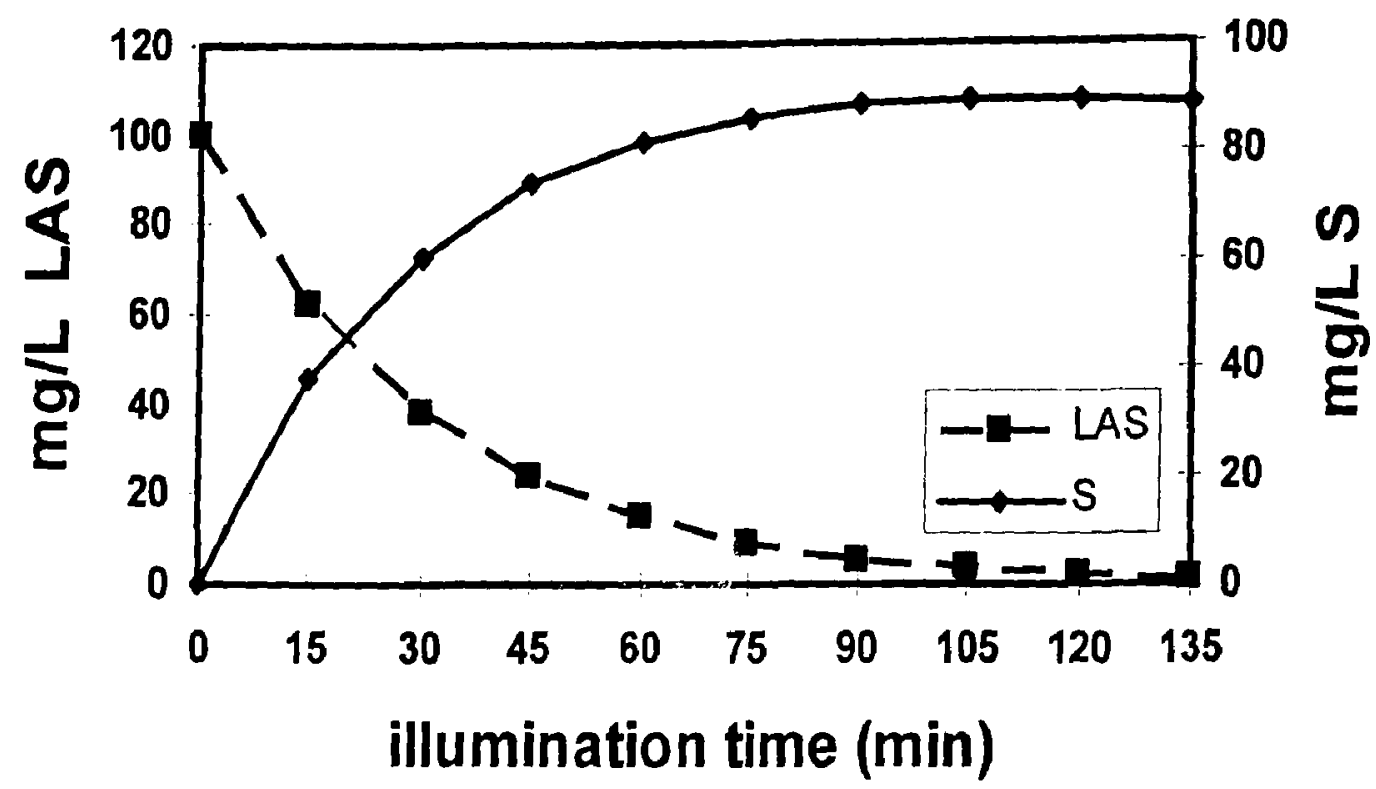

Figure 4.34: The kinetic model for $A$ and $S$ in the photolytic reactor. $A$ is the compound to be degraded and $\mathrm{S}$ is its intermediate produced during the reaction. 
However, both capital and operating cost are less for biological treatment than those for AOP. Moreover, different chemical and biological residence times can give the same efficiency, but just one of these residence times $\left(t_{c}=61 \mathrm{~min}\right.$ and $t_{b}=3365.58 \mathrm{~min}$ ) can minimize the relative treatment cost. 


\section{CHAPTER 5}

\section{CONCLUSIONS AND RECOMANDATIONS}

\subsection{Conclusions}

The following conclusions could be drawn from the thesis:

1. The LAS degradation was increased by decreasing the flow rate, as the residence time of LAS in photoreactor increased. For the best case, using maximum mixing speed and lowest flow rate, the maximum degradation of LAS:was $80 \%$ during 6 hours of photolytic treatment.

2. Photolytic treatment alone is capable of degrading LAS in 120 min with the degradation rate of only $40 \%$. UV-C alone can degrade the organics by breaking their bonds directly. This breakage is possible only when the bond energy is less than the wavelength energy.

3. The optimum concentration of $\mathrm{H}_{2} \mathrm{O}_{2}$ which should be used for the photochemical treatment of LAS with UV and $\mathrm{H}_{2} \mathrm{O}_{2}$ was $720 \mathrm{mg} / \mathrm{L}$. The photolytic treatment with the aid of hydrogen peroxide can degrade LAS up to $95 \%$ in $120 \mathrm{~min}$. This can be due to the ability of hydrogen peroxide to produce hydroxyl radicals, which in tern can react with the organics directly.

4. The chemical degradation of LAS led to produce intermediates, which were more biodegradable than LAS at the concentration of $100 \mathrm{mg} / \mathrm{L}$. This increase was much more while UV was combined by hydrogen peroxide.

5. The biodegradability of LAS highly depends on its concentration. LAS at the concentration of $100 \mathrm{mg} / \mathrm{L}$ is non-biodegradable and has inhibitory effect on microorganisms, while LAS at the concentration of $10 \mathrm{mg} / \mathrm{L}$ is more biodegradable than LAS at $100 \mathrm{mg} / \mathrm{L}$.

6. The biodegradation of pre-treated LAS by combination of $\mathrm{UV}$ and $\mathrm{H}_{2} \mathrm{O}_{2}$ by mixed culture of microorganisms was successful. The concentration of pre-treated LAS decreased to $0.5 \mathrm{mg} / \mathrm{L}$ during 11 days in shake flask experiment. 
7. Adapting the activated sludge in the SBR to LAS at the concentration of $10 \mathrm{mg} / \mathrm{L}$ resulted to an increase in the degradation rate of LAS. As the pre-treated LAS was degraded only in 48 hours.

8. Adsorption of LAS to the sludge plays an important role in the removal of LAS from the liquid phase. This problem becomes more obvious at the higher concentrations. Therefore, chemical pre-treatment for higher concentrations of LAS is highly recommended.

9. The pre-treated LAS at concentration of $10 \mathrm{mg} / \mathrm{L}$ is less biodegradable than that of untreated LAS at $10 \mathrm{mg} / \mathrm{L}$. This can be due to the high concentration of the

I. ... intermediates in the effluent of photo-chemical treatment. This implies that LAS at the lower concentration $(10 \mathrm{mg} / \mathrm{L})$ is even more biodegradable than pre-treated LAS, but at higher concentrations $(100 \mathrm{mg} / \mathrm{L})$ pre-treated LAS is more biodegradable than untreated LAS.

10. By mathematical calculations it was observed that to obtain the total efficiency of $95 \%$ in the chemical reactor alone, the residence time of chemical reactor should be about 50 hours; however, coupling the chemical reactor with the biological reactor led the chemical residence time to about 1 hour $(61 \mathrm{~min})$. Moreover, this coupling can decrease the relative cost.

\subsection{Recommendations}

The following recommendations could be suggested:

1. The main problem in the biological experiments was the presence of unknown intermediates, which were produced during photolytic oxidation of LAS. If those intermediates were known, the acclimation procedures could be done by using them instead of LAS, as they are supposed to present in the chemical effluent in high concentrations. Therefore, the biomass in the activated sludge was adapted to them and could degrade the pre-treated influent in a very short period of time. Moreover, the intermediates should be known and the kinetic parameters for the intermediates could be measured and the optimization procedures could be done more accurately. 
However, modeling the removal of LAS considering the mass transfer between liquid and solid phases could be a better model.

2. It is suggested that TOC analysis are done, as it could predict the degrees of removal of organics during both chemical and biological processes. Furthermore, DOC results could be used to calculate the partial oxidation parameters, which set the optimal point for the oxidative treatment. The shorter reaction time avoids the high electrical cost of the reaction. At longer photo-treatment time, the photochemical efficiency is improved by the unnecessary photo-degradation of pollutants which are biologically degraded. This point could then be compared with what was obtained through optimization techniques.

3. It is suggested to model the optimization of photochemical treatment of LAS combined by biological process by knowing the exact kinetic rate constants for the intermediates and considering the effect of adsorption of LAS to the sludge during its biological treatment. 


\section{REFERENCES}

1. Adams, C.D.; Cozzens, R.; Kim, B. Effects of ozonation on the biodegradability of substituted phenols, Wat. Res., 31(10), 2655-2663, 1997.

2. Kitis, M.; Adams, C. D.; Kuzhikannil, J.; Daigger, G.T, Effects of $\mathrm{O}_{3} / \mathrm{H}_{2} \mathrm{O}_{2}$ peroxide pretreatment on the aerobic biodegradability of nonionic surfactants and polypropylene glycol, Envir. Sci. Tech., 34, 2305-2310, 2000.

3. Adams, C. D.; Kuzhikannil, J. Effects of UV/ $\mathrm{H}_{2} \mathrm{O}_{2}$ preoxidation on the aerobic biodegradability of quaternary amine surfactants, Wat. Res., 34(2), 668-672, 2000.

4. Arsalan-Alaton, I.; Balcioglu, I. A. Biodegradability assessment of ozonated raw and biotreated pharmaceutical wastewater. Environ. Contam. Toxicol, 43, 425$431,2002$.

5. Andreozzi, R.; Caprio, V.; Insola, A.; Marotta, R., Advanced oxidation processes AOP) for water purification and recovery. Catalysis Today, 53, 51-59, 1999.

6. Andreozzi, R.; Longo, G.; Majone, M.; Modesti, G. Integrated treatment of olive oil mill effluents (OME): study of ozonation coupled with anaerobic digestion, Wat. Res, 32(8), 2357-2364, 1998.

7. Aye, T.; Mehrvar, M.; Anderson, W. A., Effects of photocatalysis on the biodegradability of Cibacron Brilliant yellow 3G-P Reactive Yellows), $J$. of Environmental Sci. and Health: part A: toxic/hazardous substances \& Env. Eng., A39(1), 113-126, 2004.

8. Balcioglu, I.A.; Arsalan, I., Application of photocatalytic oxidation treatment to pretreated and raw effluents from the kraft bleaching process and textile industry. Environmental Pollution, 103, 261-268, 1998.

9. Arsalan, I.; Balcioglu, I. A., Advanced oxidation of raw and biotreated textile industry wastewater with $\mathrm{O}_{3}, \mathrm{H}_{2} \mathrm{O}_{2} / \mathrm{UV}-\mathrm{C}$ and their sequential application, $J$. Chem. Tech. \& Biotech., 76, 53-60, 2001.

10. Bankian Tabrizi G. and Mehrvar M., Integration of advanced oxidation technologies and biological processes: recent developments, trends, and advances. Journal of Environmental Science and Health, A39 (11), 1-53, 2004.

11. Beltran, F. J; Garcia-Araye, J. F.; Alvarez, P. M.,. Integration of continuous biological and chemical treatment of domestic wastewater: 1 . Biodegradation and post ozonation., J. Chem. Technol. Biotech., 74, 877-883., 1999a. 
12. Beltran, F. J; Garcia-Araye, J. F.; Alvarez, P. M., Integration of continuous biological and chemical treatment of domestic wastewater: 2.ozonation followed by biological oxidation, J. Chem. Technol. Biotech., 74, 884-890, $1999 \mathrm{~b}$.

13. Beltran, F. J.; Garcia-Araya, J. F.; Alvarez, P. M., Continuous flow integrated chemical (ozone)- activated sludge system treating combined agroindustrialdomestic wastewater, Envi. Prog, 19(1), 28-35, 2000.

14. Beltran, F. J; Alvarez, P.M.; Rodriguez, E.M; Garcia-Araya, J.F.; Rivas, J. Treatment of high strength distillery wastewater (cherry stillage) by integrated aerobic biological oxidation and ozonation, Biotechnol. Prog., 17, 462-467, 2001.

15. Beltran-Heredia, J.; Tooregrosa, J.; Dominguez, R.; Garcia, J., Treatment of black-olive mill wastewater by ozonation, aerobic degradation. Wat. Res., 34(14), 3515-3522., 2000.

16. Beltran-Heredia, J.; Tooregrosa, J.; Garcia, J.; Dominguez, J. R.; Tierno, J.C. Degradation of olive mill wastewater by the combination of Fenton's reagent and ozonation processes with an aerobic biological treatment. Wat. Sci. \& Technol., , 44(5), 103-108, 2001.

17. Benitez, F.J.; Beltran-Heridia, J.; Tooregrosa, J; Acero, J.L.,Treatment of olive mill wastewater by ozonation, aerobic degradation and the combination of both treatments., J. chem. Tech. \& Biotech.,74, 639-646, 1999.

18. Benitez, F. J.; Beltran-Heredia, J.; Real, F. J.; Acero, J.L., Enhancement of the ozonation of wine distillery wastewaters by an aerobic pretreatment, Bioprocess Eng., 21, 459-464, 1999.

19. Berna, JL., Ferrer, J., Moreno, A., Prats, D., and Bevia, F., The fate of LAS in the environment, Tenside Surf Det. , 26, 101-107, 1989.

20. Bertanza, G.; Collivignarelli, C.; Pedrazzani, R. The role of chemical oxidation in combined chemical- physical and biological processes, Wat. Sci. Tech., 44(5), 109-116, 2001.

21. Brandt, K. K; Hesselsoe, M.; Roslev, P.; Henriksen, K.; and Sorensen, J., Toxic effects of linear alkylbenzene sulfonate on metabolic activity, growth rate, and microcolony formation of nitrosomonas and nitrosopira strains, Applied Environ. Microbiol, June 67 (6), 2489-2498, 2001.

22. Bolton, J. R.; Cater, S. R. Homogenous photodegradation of pollutants in contaminated water: an introduction. In G. R. Helz, R. G. Ze, and D. G. Crosby, editors, aquatic and surface photochemistry, 467-490, 1994. 
23. Braun, A. M.; Oliveros, E., How to evaluate photochemical methods for water treatment, Wat. Sci. Tech., 35 (4), 17-23, 1997.

24. Cassidy, D.; Hampton, D. ; Kohler, S. Combined chemical ozone) and biological treatment of polychlorinated biphenyls PCBs) adsorbed to sediments. J. Chem. Technology and Biothec., 77, 663-670, 2002.

25. Chun, H.; Yizhong, W. Decolorization and biodegradability of photocatalytic treated azo dyes and wool textile wastewater, Chemosphere, 39(12), 2107-2115, 1999.

26. Cserhati, T., Forgacs, E., and Oros, G., Biological activity and environmental impact of anionic surfactants, Environmental International, 28, 337-348, 2002.

27. Cuzzola, A.; Bernini, M.; and Salvadori, P., A preliminary study on iron species as heterogeneous catalysts for the degradation of linear alkylbenzene sulphonic acids by $\mathrm{H}_{2} \mathrm{O}_{2}$, Applied Catalysis B: Environmental, 36, 231-237, 2002.

28. De Almeida J.L. G. ; Dufaux M. ; Taarit Y. B. ; Naccache C., Linear alkylbenzene, J. Am. Oil Chem. Soc., , 71, 675-694, 1994.

29. Eckenfelder, Jr., W., Industrial Water Pollution Control, $3^{\text {rd }}$ Edition, Boston: MacGraw Hill. c2000.

30. http://www.epa.gov/safewater/rads/radfr.html, last revised 2004, date accessed: 19 May 2004.

31. http://biology.kenyon.edu/BMB/Chime/catalase, last updated 2004, date accessed: 19 May 2004.

32. http://crystal.uah.edu, last updated 2000, date accessed: 19 May 2004.

33. Fahmi ;Nishijima, W.; Okada, M. Improvement of DOC removal by multi-stage AOP-biological treatment, Chemosphere, 50 , 1043-1048, 2003.

34. Fettig, J.; Stapel, H.; Steinert, C.; Geiger, M. Treatment of landfill leachate by preozonation and adsorption in activated carbon columns. Wat. Sci. Tech., 34(9), 33-40, 1996.

35. Garcia-Morales, J.L.; Nebot, E; Romero, L.I.; and Sales, D., Comparison between acidogenic and methanogenic inhabitation caused by linear alkylbenzene sulfonate, Chem. Biochem. Eng., 15(1), 13-19, 2001.

36. Gavala, H. and Ahring, B., Inhibition of anaerobic digestion process by linear alkylbenzene sulfinate, Biodegradation, 13, 201-209, 2002. 
37. Gulyas, $H$. Processes for the removal of recalcitrant organics from industrial wastewaters, Wat. Sci. Tech., 36(2-3), 9-16, 1997.

38. Helble, A.; Schlayer, W.; Liechti, P.; Jenny, R.; Mobius, C. H., Advanced effluent treatment in the pulp and paper industry with a combined process of ozonation and fixed bed biofilm reactors, Wat. Sci. Tech., 40(11-12), 343-350, 1999.

39. Hofer, R., Jeney, Z., and Bucher, F., Chronic effects of linear alkylbenzene sulfonate and ammonia on rainbow trout fry at water criteria limits, Wat. Res., 29(12), 2725-2729, 1995.

40. Hong, P.K.A; Zeng, Y. Degradation of pentachlorophenol by ozonation and biodegradability of intermediates, Wat. Res., 36, 4243- 4254, 2002.

41. Huang, X., Ellis, T., and Kaiser, S., Extant biodegradation testing with linear alkylbenzene sulfonate in laboratory and field activated sludge systems, Water Environmental Federation, 2000

42. Irvine, R.; and Ketchun, L.; Sequential batch reactors for biological wastewater treatment, CRB critical reviews in Environmental Control, 18 (4), 255-294, 1989.

43. Ito, K.; Jian, W.; Nishijima, W. Baes, A. U., Shoto, E., Okada, M., Comparison of ozonation and AOPs combined with biodegradation for removal of THM precursors in treated sewage effluents, Wat. Sci. Tech., 38(7), 179-186, 1998.

44. Jochimsen, J. C.; Jekel, M. R, Partial oxidation effects during the combined oxidative and biological treatment of separated streams of tannery wastewater. Wat. Sci. Tech, 35(4), 337-345, 1997.

45. Kaiser, S. K, Guckert, J. B., and Gledhill, D. W., Comparision of activated sludge microbial communities using biolog ${ }^{\mathrm{TM}}$ microplates, The $2^{\text {nd }}$ International IAWQ Conference on Microorganisms in Activated sludge and biofilm prcesses, Berkeley, California, , July, 21-23, 1997.

46. Kamiya, T.; Hirotsuji, J. New combined system of biological process and intermittent ozonation for advanced wastewater treatment. Wat. Sci. Tech., 38(89), 145-153, 1998,

47. Kao, C. M; Wu, M. J. Enhanced TCDD degradation by Fenton's reagent preoxidation, J. Hazardous Materials, B74, 197-211, 2000.

48. Karrer, N. J.; Ryhiner, G.; Heinzle, E. Applicability test for combined biologicalchemical treatment of wastewater containing biorefractory compounds, Wat. Res., 31(5), 1013-1020, 1997. 
49. Kitis, M.; Adams, C. D.; Daigger, G.T., The effects of Fenton's reagent pretreatment on the biodegradability of nonionic surfactants. Wat. Res., 3(11), 2561-2568, 1999.

50. Kornmuller, A.; Wiensmann, U. Continuous ozonation of polycyclic aromatic hydrocarbons in oil/water - emulsions and biodegradation of oxidation products, Wat. Sci. Tech, 40(4-5), 107-114, 1999.

51. Kosaka, K.; Yamada, H.; Matusi, S.; Echigo, S; and Shishida, K.; Copmparison among the methods for hydrogen peroxide measurements to evaluate advanced oxidation processes: application of a spectrophotometric method using copper (II) ion and 2,9- dimethyl-1,10- phenamthroline, Environ. Sci. Technol., 32, 3821$3824,1998$.

52. Ledakowicz, S. and Gonera, M., Optimization of oxidants dose for combined chemical and biological treatment of textile wastewater, Wat. Res., 33(11), 25112516, 1999.

53. Ledakowicz, S.; Solecka, M.; Zylla, R., Biodegradation, decolourisation and detoxification of textile wastewater enhanced by advanced oxidation processes, $J$. of Biotech, 89, 175-184, 2001.

54. Levenspiel, O., Chemical reaction engineering, third edition, John Wiley and sons, INC. 1999, 3rd ed.

55. Lee, H.H.W; Chen, G.; Yue, P.L., Integration of chemical and biological treatments for textile industry wastewater. Wat. Sci. Tech., 44(5), 75-83, 2001.

56. Lewis, M., Chronic and sublethal toxicities of surfactants to aquatic animals: a review and risk assessment, Wat. Res., 25, 101-103, 1991.

57. Li, Z. X.; Zhang, M.; Chua, H. Disinfection of municipal wastewater by sensitized photooxidation, Wat. Sci. Tech., 33(3), 111-118, 1996.

58. Li, X. Z.; Zhao, Y. G. Advanced treatment of dyeing wastewater for reuse, Wat. Sci. Tech., 39(10-11), 249-255, 1999.

59. Lin, S., Lin, C., and Leuoperating, H., Operating characteristics and kinetic studies of surfactant wastewater treatment by Fenton oxidation, Wat. Res., 33(7), 1735-1741, 1999.

60. Mantzavinos, D., Burrows, D., Willey, R., Biundo, G., Zhang, S., Livingston, A., and Metcalfe, I., Wet air oxidation of aqueous solution of linear alkylbenzene sulfonate, Ind. Eng. Chem. Res., 39, 3659-3665, 2000. 
61. Marco, A.; Esplugas, S.; Saum, G. How and why combine chemical and biological processes for wastewater treatment. Wat. Sci. Tech., 35(4), 321-327, 1997.

62. Gonzalez-Mazo, E. and Gomez-Parra, A., Monitoring anionic surfactants (LAS) and their intermediate degradation products in the marine environment, Trends in analytical chemistry, 15, No. 8, 375-380, 1996

63. Mehrvar, M.; Anderson, W.A.; Moo-Young, M., Photocatalytic degradation of aqueous organic solvents in the presence of hydroxyl radical scavengers, Int. $J$. Photoenergy, , 3 (4), 187-190, 2001.

64. Meric, S.; Kabdash , I.; Tunay, O.; Orhon, D. Treatability of strong wastewater om polyester manufacturing industry, Sci. Tech., 39(10-1, ), 1-7, 1999.

65. Metcalf and Eddy. Wastewater Engineering, Treatment and Reuse, $4^{\text {th }}$ edition, revised by Tchobanoglous,G.; Burton, F.; Stensel, H., Dubuque, IA, MacGraw Hill. 2002.

66. Mobius, C. H; Cordes-Tolle, M. Enhanced biodegradability by oxidative and radiative wastewater treatment. Wat. Sci. Tech., 35(2-3), 245-250, 1997.

67. Mochidzuki, K.; Takeuchi, Y. Improvement of biodegradability of ethylenediaminetetraacetic acid in biological activated carbon treatment by chemical preoxidation., Separation Purification Technology, 17, 125-130, 1999.

68. Nadarajah, N.; Hamme, J.V.; Pannu, J.; Singh, A.; Ward, O., Enhanced transformation of polycyclic aromatic hydrocarbons using a combined Fenton' reagent, microbial treatment and surfactants, Applied. Microbial Biotechnology, 59, 540-544, 2002.

69. Navas, J.M.; Gonzalez-Mazo, E.; Wenzel, A.; Gomez-Parra, A.; and Segner, H., Linear alkylbenzene sulfonates and intermediates from their degradation are not Estrogenic, Marine Pollution Bulletin, 38(10), 880-884, 1999.

70. Nishijima, W.; Kim, W.H.; Shoto, E.; Okada, M., The performance of an ozonation -biological activated carbon process under long-term operation. Wat. Sci. Tech., 38(6), 163-169, 1998.

71. Nishijima, W.; Fahmi ;Mukaidani, T.; Okada, M., DOC removal by multi-stage ozonation -biological treatment, Wat. Res. 37, 150-154, 2003.

72. Park, S. J.; Yoon, T. I.; Bae, J.H.; Seo, H.J; Park, H. J, Biological treatment of wastewater containing dimethyl sulphoxide from the semi-conductor industry, Proc. Biochem., 36, 579-589, 2001. 
73. Parra, S., Sarria, V., Malato, S., Peringer, P., Pulgarin, C., Photochemical versus coupled photochemical -biological flow system for the treatment of two biorecalcitrant herbicides: metobromuron and isoproturon, Allied Catalysis B., 27, 153-168, 2000.

74. Parra, S.; Malato, S.; Pulgarin, C. New integrated photocatalytic-biological flow system using supported $\mathrm{TiO}_{2}$ and fixed bacteria for the mineralization of isoproturon, Allied Catalysis B, 36, 131-144, 2002.

75. Patterson, D., Metcalfe, I., Xiong, F., and Livingston, A., Biodegradability of linear alkylbenzene sulfonates subjected to wet air oxidation, J. Chem. Technol Biotechnol, 77, 1039-1049, 2002.

76. Pülgarin, iC.; Invernizzi, M.; Parra, S.; Sarria, V.; Polania, R.; Peringer, P. Strategy for the coupling of photochemical and biological flow reactor useful in mineralization of biorecalcitrant industrial pollutants. Catalysis Today, 54, 341$353,1999$.

77. Reemtsma, T., Methods of analysis of polar aromatic sulfonates from aquatic environment , J. Chromatogr., 733, 473-489, 1996.

78. Rittmann, B., Tularak, P., Lee, K., Federle, T., Itrich, N., Kaiser, S., Shi, J., and McAvoy, D., How adaptation and mass transfer control the biodegradation of linear alkylbenzenesulfonate by activated sludge, Biodegradation, 12, 31-37, 2001.

79. Saien, J., Ardjmand, R., and Iloukhani, H., Photocatalytic decomposition of sodium dodecyl benzene sulfonate under aqueous media in the presence of $\mathrm{TiO}_{2}$, physics and chemistry of liquids, 4I(5), 519-531, 2003.

80. Sarria, V.; Parra, S.; Invernizzi, M.; Peringer, P.; Pulgarin, C., Photochemicalbiological treatment of a real industrial biorecalcitrant wastewater containing 5 amino-6-methyl-2-benzimidazolone. Wat. Sci. Tech., 44(5), 93-101, 2001.

81. Scott, J. P.; Ollis. D. F, Integration of chemical and biological oxidation processes for water treatment: review and recommendations, Environmental. Prog., 14(2), 88-103, 1995.

82. Scott, J. P.; Ollis. D. F, Engineering models of combined chemical and biological processes, J. Environmental Eng., 122(12), 1110-1114, 1996.

83. Sigger, G. O.; Britz, T.J.; Fourie, P. C.; Barnardt, C. A.; Strydom, R., Use of ozone and hydrogen peroxide in the post-treatment of UASB treated alkaline fruit cannery effluent, Wat. Sci. Tech., 44(5), 69-74, 2001. 
84. Standard Methods for the Examination of Water and Wastewater, published jointly by American public health association, American water works association, water environment federation, $20^{\text {th }}$ edition, 1998.

85. Tabor, CF.; Barber, LB., Fate of linear alkylbenzene sulfonate in the Mississippi river, Environmental. Sci. Technol., 30, 161-171, 1996.

86. Takada, H.; Mutoh, K.; Tomita, N.; Miyadzu, T.; and Ogura, N., Rapid removal of linear alkylbenzene sulfonates by attached biofilm in an urban shallow stream, Wat. Res., 28 (9), 1953-1960, 1994.

87. Treybal, R.E, Mass-transfer operations, New York : McGraw-Hill, c1980, 3d ed.

88. Trehy, ML.; Gledhill, WE. ; Mieure, JP.; Adamove, JE.; Nielsen, AnM.; Perkins, HO., and Eckhoff, JE., Environmental monitoring for linear alkylbenzene sulfonates, dialkyltetralin sulfonates and their biodegradation intermediates, Environmental toxicology and chemistry, , 15, 233-240, 1995.

89. Van Ginkel, C.G., Complete degradation of xenobiotic surfactants by consortia of aerobic microorganisms, Biodegradation, 7, 151-164, 1996.

90. Vazquez, G.; Antorrena, G.; Navaza JM., Influence of surfactant concentration and chain length on the absorption of $\mathrm{CO}_{2}$ by aqueous surfactant solution in the presence and absence of induced Marangoni effect. Ind Eng Chem Res, , 39, 1088-94, 2000.

91. Venhuis, S.H. and Mehrvar, M., Health effects, Enviromental impacts, and photochemical degradation of selected surfactants in water, International Journal of Photoenergy, 6(3), 115-125, 2004

92. WHO, Linear Alkilbenzene Sulfonates and related compounds, environmental health criteria No.169, United Nations Environment Program, 1996. International Labour Organization and World Health Organization. WHO, Geneva.

93. Yeber, M.C.; Rodriguez, J.; Baeza, J.; Freer, J.; Zaror, C.; Duran, N; Mansilla, H.D., Toxicity abatement and biodegradability enhancement of pulp mill bleaching effluent by advanced chemical oxidation, Wat. Sci. Tech, 40(11-12), 337-342, 1999.

94. Yu, G.; Zhu, W.; Yang, Z., Pretreatment and biodegradability enhancement of DSD acid manufacturing wastewater, Chemosphere, 37(3), 487-494, 1998.

95. Zenaitis, M.; Sandhu, H.; Duff, S., Combined biological and ozone treatment of log yard run-off, Wat. Res., 36, 2053-2061, 2002. 
96. Zeng, Y.; Andrew Hong, P. K.; Wavrek, D. A., Chemical-biological treatment of pyrene, Wat. Res., 34(4), 1157-1172, 2000.

97. Zhang, C.; Valsaraj, K. T.; Constant, W. D.; and Roy, D., Aerobic biodegradation kinetics of four anionic and nonionic surfactants at sub- and supra-critical micelle concnetratins (CMCs), Wat. Res., 33(1), 115-124, 1999.

98. Zhang, Z.; Anderson, W. A.; Moo-Young, M., Photocatalytic pretreatment of contaminated groundwater for biological nitrification enhancement, J. Chem. Tech. Biotech., 77, 190-194, 2002.

99. Zhou, H.; Smith, D.W., Advanced technologies in water and wastewater treatment. Can. J. Civil Eng., 28(suppl.1), 49-66, 2001. 


\section{APPENDIX A}

\section{(a) Calculation for $\mathrm{BOD}_{5}$}

Initial DO in the blank: 8.24

Initial DO in the sample: 8.30

DO after 5 days in the blank: 7.59

DO after 5 days in the sample: 6.13

Volum: of sample added to BOD bottles: $30 \mathrm{~mL}$

$f$ : ratio of seed in diluted sample to seed in seed control $=1$

P: volumetric fraction of sample $=30 / 300=0.1$

Using Equation (3.8) (Metcalf and Eddy, 2002):

$$
B O D_{5}=\frac{(8.30-6.13)-(8.24-7.59)}{0.1}=15.2 \quad \mathrm{mg} / \mathrm{L} \mathrm{O}_{2}
$$

\section{(b) Biodegradability factor, $\mathbf{f}_{B}$}

$\mathrm{COD}_{\mathrm{o}}, \mathrm{COD}$ of untreated $\mathrm{LAS}=183 \mathrm{mg} / \mathrm{L} \mathrm{O}_{2}$

$\mathrm{COD}_{\mathrm{t}}, \mathrm{COD}$ after $1 \mathrm{~h}$. pre-treatment $=145 \mathrm{mg} / \mathrm{L} \mathrm{O}_{2}$

$\mathrm{BOD}_{5, \mathrm{t},}, \mathrm{BOD}_{5}$ after $1 \mathrm{~h}$. pre-treatment $=54 \mathrm{mg} / \mathrm{L} \mathrm{O}_{2}$

$\mathrm{BOD}_{5,0}, \mathrm{BOD}_{5}$ of untreated LAS $=15 \mathrm{mg} / \mathrm{L} \mathrm{O}_{2}$

$f_{B}=\frac{B O D_{s, d}\left(C O D_{t}\right)^{-1}}{B O D_{5,0}\left(C O D_{0}\right)^{-1}}$

(Eq. 2.16) (Arsalan and Balciglu, 2001):

$f_{B}=\frac{54 \times(145)^{-1}}{15 \times(183)^{-1}}=4.5$

\section{(c) COD removal}

$\mathrm{COD}_{0}, \mathrm{COD}$ of untreated $\mathrm{LAS}=183 \mathrm{mg} / \mathrm{L} \mathrm{O}_{2}$ 
$\mathrm{COD}_{\mathrm{t}}, \mathrm{COD}$ after $1 \mathrm{~h}$. pre-treatment $=145 \mathrm{mg} / \mathrm{L} \mathrm{O} \mathrm{O}_{2}$

$$
\begin{aligned}
& X_{C O D}=\frac{C O D_{o}-C O D_{f}}{C O D_{o}} \times 100 \\
& X_{C O D}=\frac{183-145}{183} \times 100=21 \%
\end{aligned}
$$

\section{(d) Calculation for the non-biodegradable COD}

For pre-treated sample for 1.5 hours:

$$
\begin{aligned}
& \mathrm{UBOD}=60 \quad \mathrm{mg} / \mathrm{L} \mathrm{O} \\
& \mathrm{T}(\mathrm{COD})=145 \quad \mathrm{mg} / \mathrm{L} \mathrm{O}_{2} \\
& \mathrm{UBOD}=0.92 \times(\mathrm{COD})_{\mathrm{d}} \\
& \because(\mathrm{COD})_{\mathrm{d}}=65 \quad \mathrm{mg} / \mathrm{L} \mathrm{O}_{2} \\
& \mathrm{~T}(\mathrm{COD})=(\mathrm{COD})_{\mathrm{d}}+(\mathrm{COD})_{\text {nondegradable }} \\
& \because(\mathrm{COD})_{\mathrm{n}}=80 \mathrm{mg} / \mathrm{L} \mathrm{O} \mathrm{O}_{2}
\end{aligned}
$$

\section{(e) Theoretical Oxygen Demand (ThOD)}

$$
\mathrm{C}_{12} \mathrm{H}_{25} \mathrm{C}_{6} \mathrm{H}_{4} \mathrm{SO}_{3} \mathrm{Na}
$$

$\mathrm{ThOD}=\frac{\left(18 \mathrm{C}+7.25 \mathrm{H}_{2}+2 \mathrm{~S}-3 / 2 \mathrm{O}_{2}+1 / 2 \mathrm{Na}\right) \times 32}{F W}$

$\mathrm{FW}=348.48 \quad \mathrm{~g} / \mathrm{gmol}$

$T h O D \approx 240 \quad \mathrm{mg} / \mathrm{L} \mathrm{O}_{2}$

\section{(f) Calculation for MLSS}

Initial weight of filter: $109 \mathrm{mg}$

Weight of filter+ sludge : $157.3 \mathrm{mg}$

Volume of sludge used: $10 \mathrm{~mL}$ 
$M L S S=\frac{\text { Weight of filter } \text { and sludge }+ \text { Initial weight of filter }}{\text { Volume of sludge used }}$ (Standard Methods, 1998)

$M L S S=\frac{157.3-109}{10}=4.83 \mathrm{~g} / \mathrm{L}$

(g) Calculation for the nitrogen and phosphorus in nutrient for biological treatment

$\mathrm{BOD}_{5}: \mathrm{N}: \mathrm{P}=100: 5: 1$

(Eckenfelder, 2000)

$\mathrm{BOD}_{5}=40 \mathrm{mg} / \mathrm{L} \mathrm{O}_{2}$

Nitrogen $=40 \times 0.05=2 \mathrm{mg} / \mathrm{L}$

Phosphorous $=40 \times 0.01=0.4 \mathrm{mg} / \mathrm{L}$

(h) Calculation for Reynolds number

$$
\begin{aligned}
& \text { Mixer Reynolds number }=\frac{d^{2} N p}{\mu} \\
& \mathrm{d}=\text { mixer diameter }=0.1 \mathrm{~m} \\
& \mathrm{~N}=\text { mixer speed }=165 \mathrm{rpm}=2.75 \mathrm{r} / \mathrm{s} \\
& \mathrm{p}=\text { density of liquid }=100 \mathrm{~kg} / \mathrm{m}^{3} \\
& \mu=\text { viscosity }=0.001 \mathrm{~kg} / \mathrm{m} . \mathrm{s} \\
& \operatorname{Re}=2750
\end{aligned}
$$

(i) Calculation for the optimum concentration of catalase to remove $\mathrm{H}_{2} \mathrm{O}_{2}$ completely.

One unit of the catalase used in this study has the ability of decomposing $1 \mu \mathrm{mol}$ of $\mathrm{H}_{2} \mathrm{O}_{2}$ per minute, and each 2380 unit of this catalase is equivalent to $1 \mathrm{mg}$ of catalase. $1 \mu \mathrm{mol}$ of $\mathrm{H}_{2} \mathrm{O}_{2}$ can be removed per minute, and $10^{-4} \mathrm{~mol}$ of $\mathrm{H}_{2} \mathrm{O}_{2}$ would be removed in 
100 minutes. Therefore, to decompose $\mathrm{H}_{2} \mathrm{O}_{2}$ at $60 \mathrm{mg} / \mathrm{L}$ which is equal to $\mathrm{H}_{2} \mathrm{O}_{2}$ at 1.7 $\mathrm{mol} / \mathrm{L}, 0.71 \mathrm{mg}$ of catalase should be added to one liter of $60 \mathrm{mg} / \mathrm{L} \mathrm{H}_{2} \mathrm{O}_{2}$ solution. This amount would be $0.071 \mathrm{mg}$ of catalase in $100 \mathrm{~mL}$ solution. However, as the detection limit for the balance used couldn't cover this range, $0.1 \mathrm{mg}$ of catalase was used.

\section{(j) Kinetic model for the intermediate}

$$
\begin{aligned}
& A \stackrel{k_{A}}{\longrightarrow} S \stackrel{k_{S}}{\longrightarrow} R \\
& r_{A}=\frac{d C_{A}}{d t}=-k_{A} C_{A} \\
& r_{S}=\frac{d C_{S}}{d t}=k_{A} C_{A}-k_{S} C_{S} \\
& \frac{C_{A}}{C_{A o}}=e^{-k_{A^{\prime}}} \\
& \frac{d C_{S}}{d t}+k_{S} C_{S}=k_{A} C_{A o} e^{-k_{A^{\prime}}}
\end{aligned}
$$

By solving the first order linear differential equation:

$$
\frac{C_{S}}{C_{A o}}=\frac{k_{A}}{k_{S}-k_{A}}\left(e^{-k_{A} c^{\prime} c}-e^{-k_{S} t_{C}}\right)
$$

\section{(k) Generalized reduced gradient (GRG 2)}

GRG2 uses an implementation of the generalized reduced gradient (GRG) algorithm. It seeks a feasible solution first (if one is not provided) and then retains feasibility as the objective is improved. It uses the quasi-Newton algorithm as its default choice for determining a search direction. 


\section{(l) Programming reports}

Adjustable Cells

\begin{tabular}{ccrr}
\hline Cell & Name & $\begin{array}{c}\text { Original } \\
\text { Value }\end{array}$ & \multicolumn{1}{c}{ Final Value } \\
\hline$\$ J \$ 15$ & ec Sa & 13.8838292 & 13.8838292 \\
\hline$\$ K \$ 15$ & ec Sb & 0.5 & 0.5 \\
\hline
\end{tabular}

Constraints

\begin{tabular}{|c|c|c|c|c|c|}
\hline Cell & Name & Cell Value & Formula & Status & Slack \\
\hline$\$ F \$ 5$ & tc & 61.50920218 & $\$ F \$ 5>=0$ & $\begin{array}{l}\text { Not } \\
\text { Binding }\end{array}$ & 61.50920218 \\
\hline$\$ G \$ 5$ & tb & 3365.871977 & $\$ G \$ 5>=0$ & $\begin{array}{l}\text { Not } \\
\text { Binding }\end{array}$ & 3365.871977 \\
\hline$\$ J \$ 15$ & ec Sa & 13.8838292 & $\$ J \$ 15>=\$ K \$ 15$ & $\begin{array}{l}\text { Not } \\
\text { Binding }\end{array}$ & 13.3838292 \\
\hline \$D\$15 & $e c$ & 0.03388381 & \$D $\$ 15>=0$ & $\begin{array}{l}\text { Not } \\
\text { Binding }\end{array}$ & 0.03388381 \\
\hline \$D\$10 & effiecency & 0.950000943 & $\$ D \$ 10=0.95$ & $\begin{array}{l}\text { Not } \\
\text { Binding }\end{array}$ & 0 \\
\hline$\$ K \$ 15$ & ec Sb & 0.5 & $\$ K \$ 15<=0.5$ & Binding & 0 \\
\hline
\end{tabular}


Microsoft Excel 10.0 Sensitivity Report

Worksheet: [optimization.xis]Sheet1

Report Created: 7/20/2004 5:38:21 PM

Adjustable Cells

\begin{tabular}{|c|c|c|c|}
\hline Cell & Name & $\begin{array}{l}\text { Final } \\
\text { Value }\end{array}$ & $\begin{array}{l}\text { Reduced } \\
\text { Gradient }\end{array}$ \\
\hline$\$ J \$ 15$ & ec Sa & 13.8838292 & 0 \\
\hline$\$ K \$ 15$ & ec Sb & 0.5 & 74.73466845 \\
\hline
\end{tabular}

Constraints

\begin{tabular}{cccr} 
Cell & Name & $\begin{array}{c}\text { Final } \\
\text { Value }\end{array}$ & \multicolumn{1}{c}{$\begin{array}{l}\text { Lagrange } \\
\text { Multiplier }\end{array}$} \\
\hline$\$ F \$ 5$ & tc & 61.50920218 & 0 \\
\hline$\$ G \$ 5$ & tb & 3365.871977 & 0 \\
\hline$\$ 1 \$ 15$ & ec Sa & 13.8838292 & 0 \\
\hline$\$ D \$ 15$ & ec & 0.03388381 & 0 \\
\hline 510 & effiecency & 0.950000943 & 305.8680046 \\
\hline
\end{tabular}


Microsoft Excel 10.0 Limits Report

Worksheet: [optimization.xls] Limits Report 1

Report Created: 7/20/2004 5:38:22 PM

\begin{tabular}{ccc}
\hline Cell & $\begin{array}{c}\text { Target } \\
\text { Name }\end{array}$ & Value \\
\hline$\$ J \$ 5$ & cost & 249.0982425 \\
\hline
\end{tabular}

\begin{tabular}{|c|c|c|}
\hline \multicolumn{3}{|c|}{ Adjustable } \\
\hline Sell & Name & Value \\
\hline \$J\$15 & ec Sa & 13.8838292 \\
\hline$\$ K \$ 15$ & $\mathrm{ec} \mathrm{Sb}$ & 0.5 \\
\hline
\end{tabular}

\begin{tabular}{rc}
\hline $\begin{array}{c}\text { Lower } \\
\text { Limit }\end{array}$ & $\begin{array}{c}\text { Target } \\
\text { Result }\end{array}$ \\
\hline 13.8838292 & $249.09821 ?:$ \\
\hline 0.5 & 249.0982420 \\
\hline
\end{tabular}

\begin{tabular}{rc}
\hline $\begin{array}{c}\text { Upper } \\
\text { Limit }\end{array}$ & $\begin{array}{c}\text { Target } \\
\text { Result }\end{array}$ \\
\hline 13.8838292 & 249.0982425 \\
\hline 0.5 & 249.0982425 \\
\hline
\end{tabular}

(4) BL-106-150 